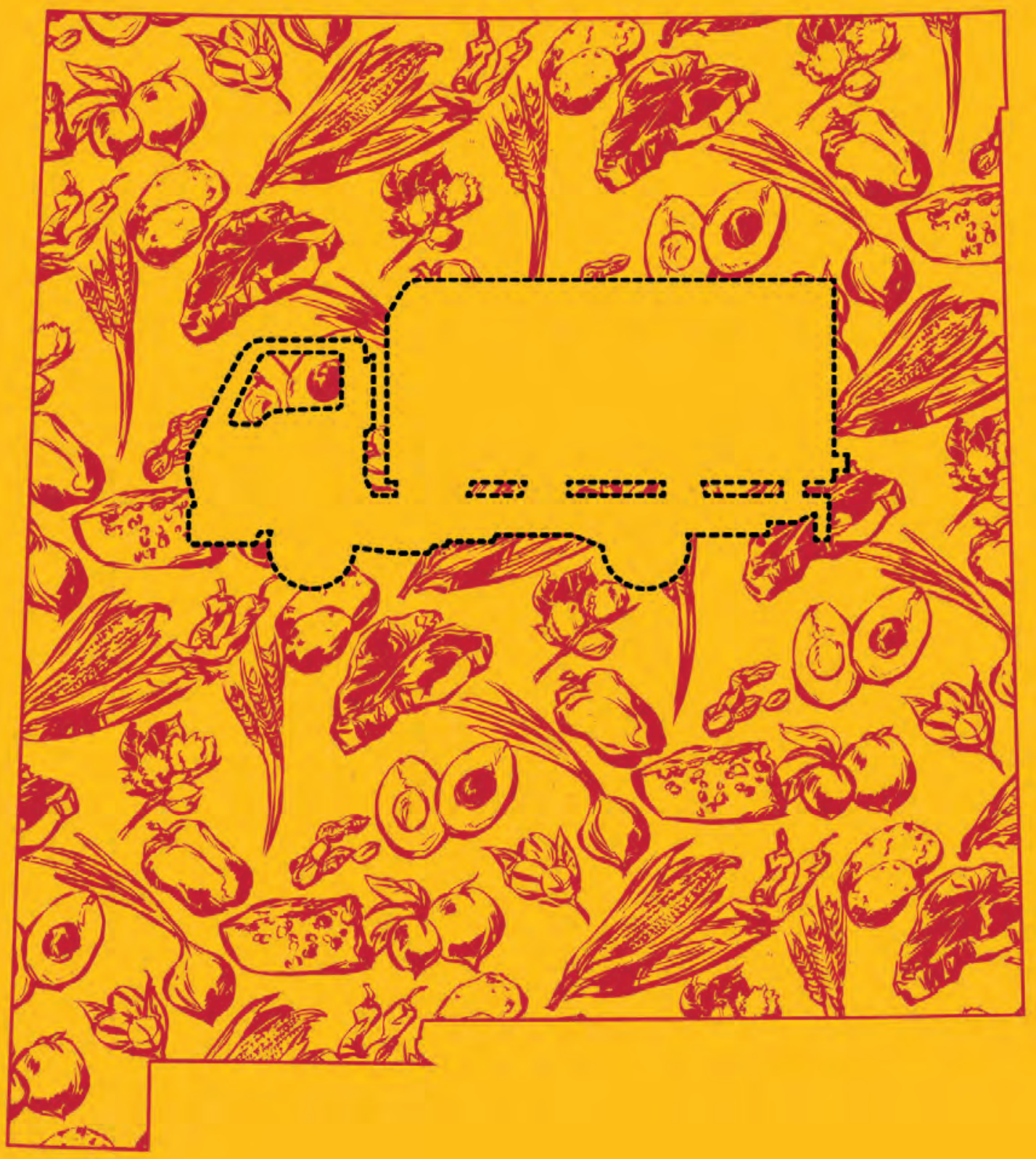

\title{
WHAT IF THE TRUCKS STOP COMING? Exploring the framing of local food by cooperative food retailers in New Mexico
}


Propositions

1. Cooperative businesses are not meant to solve a dearth of democracy but to solve problems in a democratic way. (this thesis)

2. Regardless of whether local food truly exists, it is useful. (this thesis)

3. Hardin's "tragedy of the commons" is like a newspaper article that has to be retracted but has instead gone viral.

4. A time lag between fieldwork and publication does not necessarily render research irrelevant; after all, people still find relevance in Marx's Das Kapital, written 150 years ago.

5. Continuing to work on a PhD well after the end of one's employment contract is an exercise in understanding the economic theory of sunk costs.

6. Much like Bigfoot or the Yeti, Homo economicus doesn't exist; yet neoliberalism's proponents would seek him out and invite him to dinner, rather than doing the logical thing and running as far away as possible.

Propositions belonging to the thesis, entitled "What if the trucks stop coming?: Exploring the framing of local food by cooperative food retailers in New Mexico"

Cheron Z. Constance Wageningen, 21 J une 2017 


\title{
WHAT IF THE TRUCKS STOP COMING?
}

\author{
Exploring the framing of local food \\ by cooperative food retailers in New Mexico
}

Cheron Z. Constance 


\section{Thesis committee}

\section{Promotor}

Prof. Dr J.S.C. Wiskerke

Professor of Rural Sociology

Wageningen University \& Research

\section{Co-promotors}

Dr L.G. Horlings

Adjunct Professor of Socio-Spatial Planning

University of Groningen

Dr L. Shaw

Former Vice-President of Research

UK Co-operative College, Manchester

\section{Other members}

Prof. Dr M.N.C. Aarts, Wageningen University \& Research

Dr L. Brushett, Cooperative Development Institute, United States of America

Prof. Dr C.A. Clamp, Southern New Hampshire University, United States of America Prof. Dr M. Fonte, University of Naples Federico II, Italy

This research was conducted under the auspices of the Wageningen Graduate School of Social Sciences. 


\title{
WHAT IF THE TRUCKS STOP COMING?
}

\author{
Exploring the framing of local food \\ by cooperative food retailers in New Mexico
}

Cheron Z. Constance

\author{
Thesis \\ submitted in fulfilment of the requirements for the degree of doctor \\ at Wageningen University \\ by the authority of the Rector Magnificus, \\ Prof. Dr A.P.J. Mol, \\ in the presence of the \\ Thesis Committee appointed by the Academic Board \\ to be defended in public \\ on Wednesday 21 June 2017 \\ at 1.30 p.m. in the Aula.
}


Cheron Z. Constance

What if the trucks stop coming?: Exploring the framing of local food by cooperative food retailers in New Mexico

280 pages.

PhD thesis, Wageningen University, Wageningen, the Netherlands (2017)

With references, with summary in English

ISBN: 978-94-6343-194-1

DOI: $10.18174 / 413760$ 
Dedicated to the memory of my father Dr. Brian Elwin Franklyn Constance 24 December 1947 - 19 November 2015 



\section{Acknowledgements}

In the lengthy process of this $\mathrm{PhD}$, I have made many important professional and personal connections. I will surely fail to acknowledge all those of note, timeliness, and usefulness in my rush to meet my writing deadlines. So with my apologies to anyone I miss or fail single out by name, I give thanks to all those encounters, conversations, and inspirations that have furthered this project and enriched my life over the last six years.

I first offer thanks to the participants and informants of this research process: the staff members, local suppliers and institutional customers of the cooperatives profiled in this thesis (La Montañita Food Co-op and Mountain View Market Co-op). I am grateful for your time and willingness to explain your work and your views on local food and local economics. Without your generosity and expertise, this research could not have happened. I offer additional thanks to Sarah Wentzel-Fisher in Albuquerque and to Shahid Mustafa and Niki Harings in Las Cruces for opening their homes to me.

Thanks as well to those interviewees who were not profiled in the final write up of my fieldwork, but who nonetheless contributed to the process of my research. I am also grateful for the companionship and assistance that I received while in the field from Annette Mares-Duran, Jessie Brown Swartzentruber, Charlie Alfero, Deb and Hubert van Hecke, and dear Saskia.

Thank you to my academic supervisory team: Ina Horlings, Linda Shaw, and Han Wiskerke. Thanks for your clarity and feedback throughout the process, Ina. I appreciated your attention and timeliness in always reading my drafts and commenting quickly. Linda, thank you for supervising my secondment to the College, for sharing your deep knowledge of the cooperative world, and for identifying important gaps in my approach. It was very kind of you to continue your supervision after your retirement. Thank you for your comments and attention in the last phases of writing, Han, particularly in the midst of flu and while dealing with multiple promotions.

I offer thanks to my opponents (Drs. Aarts, Brushett, Clamp, and Fonte) for participating in this process and contributing their expertise to make this day happen.

My thanks also goes to Petra Derkzen, my original daily supervisor in the PUREFOOD project. Petra, your guidance and thinking have informed this work long after you have moved on to other endeavors. I am grateful for having connected with you 
in the first years of my PhD. I am also indebted to Peter Tamas in the Wageningen department of Research Methodology for sharing his approach and commitment to rigorous social research. Our conversations - though sometimes scary-undoubtedly enabled my progress and helped me articulate what I wanted to do.

Thank you to my PUREFOOD colleagues who provided fun, inspiration, and a semblance of community - despite being in far-flung places. All my best wishes for whatever life has in store.

Diana Lee-Smith, your encouragement is a source of strength to me. I hope that I have written this loud enough. I am glad for our continued connection.

I thank the Secretariaat, faculty, and staff of Rural Sociology for all kindnesses and assistance shown to me. I also thank the former and current MSc and PhD students of SADE and WASS with whom I have connected over the years. I particularly extend my best wishes to all those PhD students working without the comforts and protections of employment contracts.

Thanks to Inge Ruisch for being a joyous, irreverent spirit and an ally. I thank Esther Roquas for her advocacy, guidance, and suggestions regarding the things that did not go so well.

I humbly offer my thanks to my friends in Wageningen and elsewhere who supported my family and me through the most harrowing and difficult experiences of my life. I cannot say how much it meant to have people to count on in the absence of a partner or family nearby. Though you all have had other roles in my life - as valued colleagues, trusted friends, (tea) drinking buddies, fellow foodies, and lovely housemates - it is your attention and care in the midst of my father's illness and death and my own health issues that I note here. My PhD process is inextricably linked with these experiences, and I am especially grateful for those who visited me in the hospital or helped my parents.

Thank you: Andrea and Matthijs, Agnese, Lara, Gina, Elisa, Ina, Matthijs K., Petra, Marcella and Lawrence, Diana Q., Cathy and Sarah, Horacio and Paola, Simon and Dan, and Zowi.

Jenny A. and Simona D., I'm so grateful for your company, assistance, and advocacy during my unexpected hospital trips. You each helped me make the best of a bad situation.

Thank you, Marty, for providing shelter, comfort, perspective, and a sounding board when I needed it. 
Mary, your presence in my family's life has been such a blessing. Thank you.

Sara H., I'm so glad to have connected with you again. You eased the loneliness of Richmond. Pilou, your stories always made me laugh and distracted me - surely the best medicine.

Thanks to my DC friends, especially Justin, Laurie, David, and Tresa, who always tried to make time and space for me whenever I was passing through.

My dear friend Lynda, I could not have asked a better and more comforting guide to begin my walk through the terrible journey of 2015. I can't imagine that I will ever like snow, but I'm grateful for the snowpocalypse allowing me to spend even more time with you.

Olivia, I don't know how I would have gotten through some of the worst of 2015 without you. I am eternally grateful for your attentiveness, our lasting friendship, and your belief me. I am in awe of your resolution to face your own battles with steadfast determination. Here's to literally turning poison into medicine!

Peer, Meira, and Elsbeth: Thank you for doing your best to keep me in good shape mentally and physically over the years. I am so much the better for your efforts. Marjannke and Lara, your friendships have each been a breath of fresh air. Thank you for being my paranymphs. Frank M., thanks for valuing my intelligence, even while challenging my ideas.

Greg, thank you for being willing to make the trip to see me defend. You were there at the very beginning, and it's wonderful that you can be here at the end.

I thank my brother Roderick for his patience, creativity, time, and talent in laying out and designing my book. Roderick, I am grateful for the care and attention with which you executed this task.

In this loneliest of endeavors, Hilde Geerling and John McBreen were the greatest support to me - one at a distance and the other in-person - and let me know that I was not alone. You two have been wonderful colleagues in spirit and in action, where I had no cohort to help me in the ways you have.

Hilde, you have been a one-woman cheering section. At times that I could no longer think, you asked pointed questions, offered suggestions, and helped me see where I had made progress and where I wanted to go next. Your perfectly-timed coffee runs and encouraging words cheered me and brought humor and humanity to late nights at the Leeuwenborch. I couldn't have had a better person to nearly get 
locked into the building with. I hope that you have someone do for you what you have done for me when you get to the last stages of your PhD. But perhaps with fewer distractions... ;-)

John, your assistance and attention in the last months of writing have been invaluable. Your questions and insightful comments brought out the best I had to offer, kept me to my deadlines, and reaffirmed the shifts in my writing. Your intellectual curiosity in my subject encouraged me to think that others would also be interested in what I had to say. I could not have finished this thesis according to my timetable without your keen eye and sharp intellect.

Finally, I would not have gotten here without the encouragement and love of my parents. No one wanted me to finish this PhD more than my father did, and I hope that I have done justice to his hopes. Though only my mother can be here to see this day, both my parents have contributed to this long-awaited culmination of my hard work. I thank my mother Annette Constance for bearing with my reclusiveness while in the last phases of writing. You have been a model of strength and perseverance.

Cheron

April 2017

St. Vincent \& the Grenadines 
Ring the bells that still can ring Forget your perfect offering

There is a crack, a crack in everything That's how the light gets in.

-Leonard Cohen 



\section{Table of Contents}

Chapter 1: Introduction ................................................................. 5

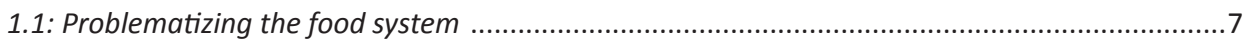

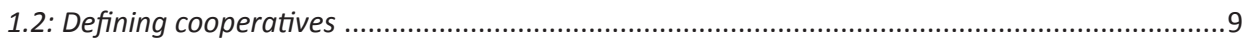

1.3: Understanding food cooperatives - past and present ..........................................................14

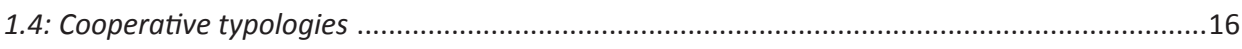

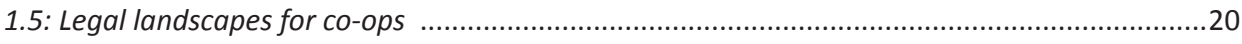

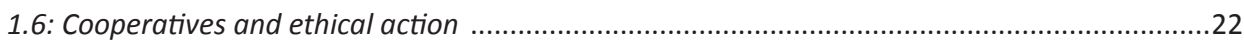

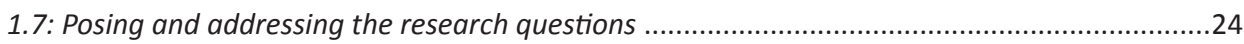

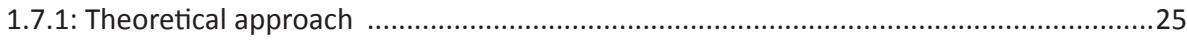

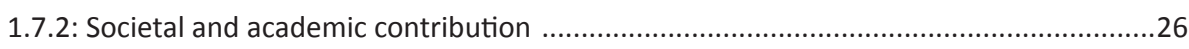

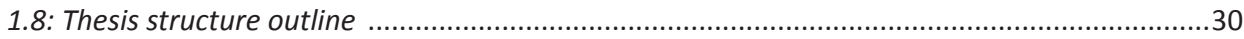

Chapter 2: Theoretical Framework ...................................................35

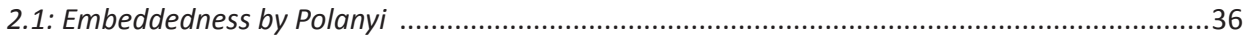

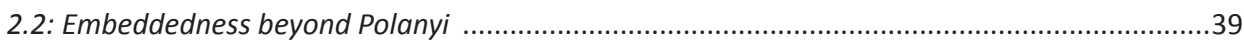

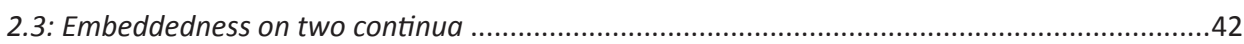

2.4: Changing the frame - from a capitalist economy to diverse economies .................................44

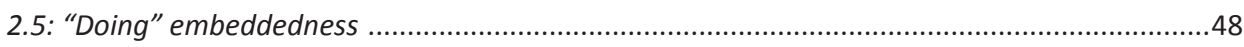

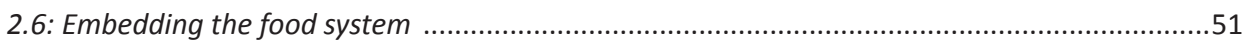

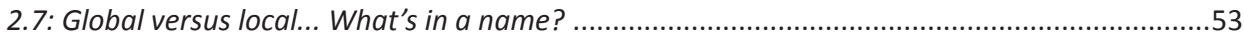

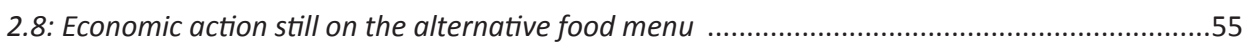

Chapter 3: Research Methodology..................................................61

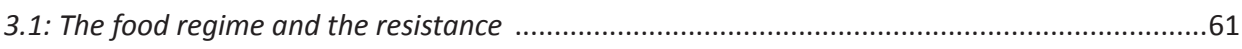

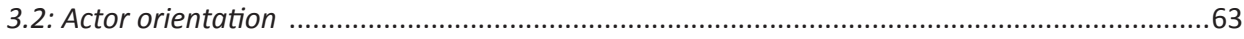

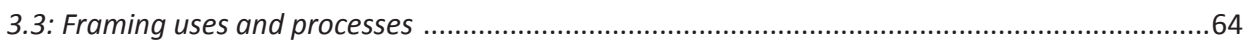

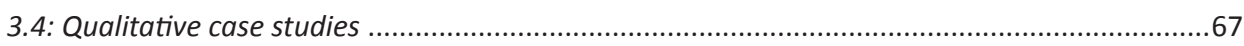

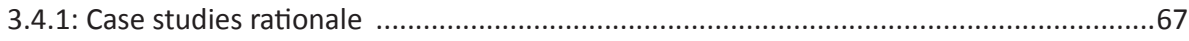

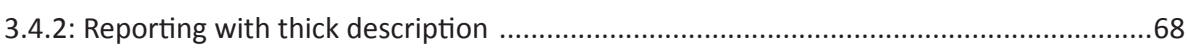

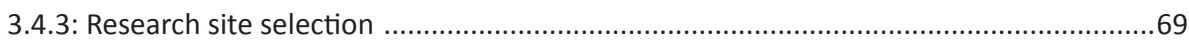

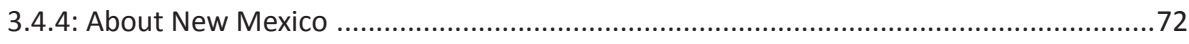

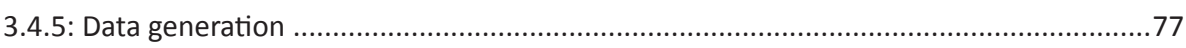

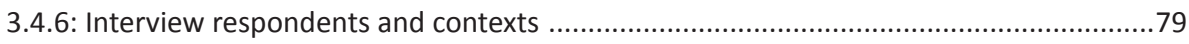

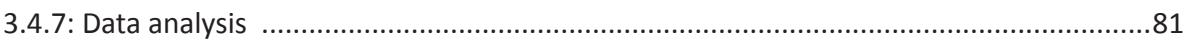

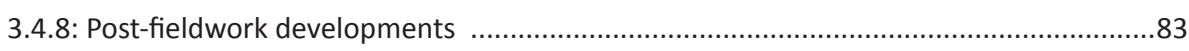


Chapter 4: Case Study of La Montañita Food Co-op .89

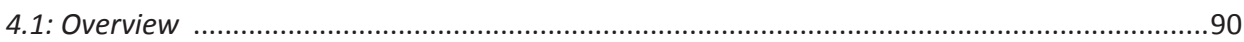

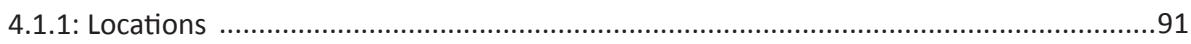

4.1.2: La Montañita, organizationally speaking …...............................................................94

4.2: Original framing of local sourcing as a strategic vision .......................................................98

4.3: Ongoing (re)framing of La Montañita's engagement with local food ................................. 103

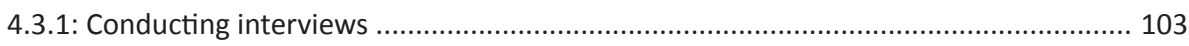

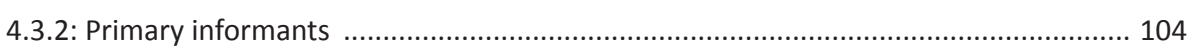

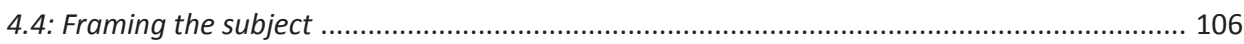

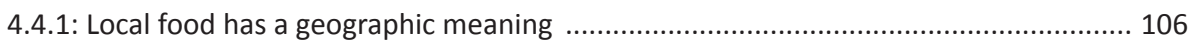

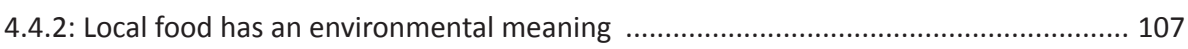

4.4.3: Local food reflects La Montañita's organizational aspirations and expertise ............. 110

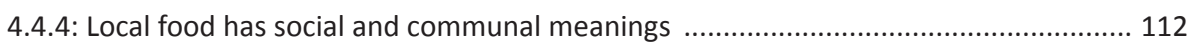

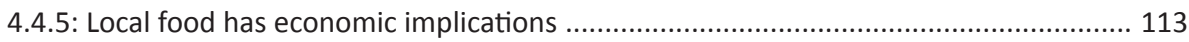

4.5: La Montañita's areas of work and practices engaging with local food .............................. 116

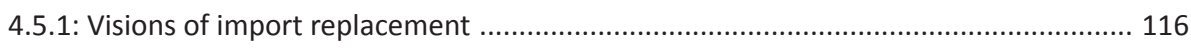

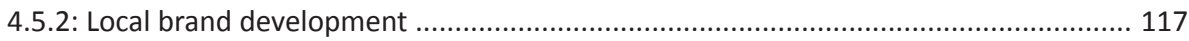

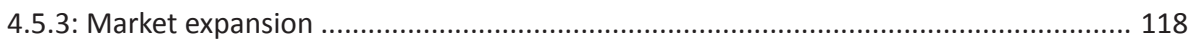

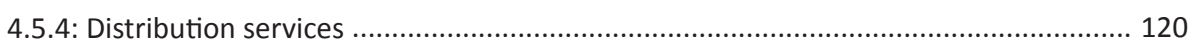

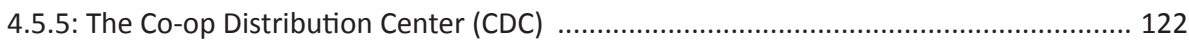

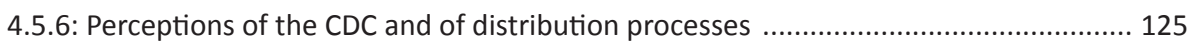

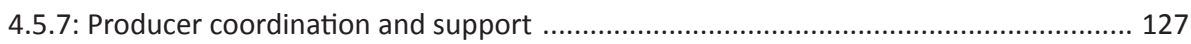

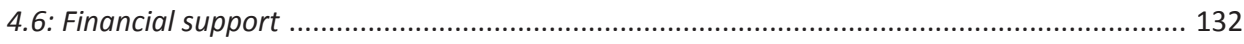

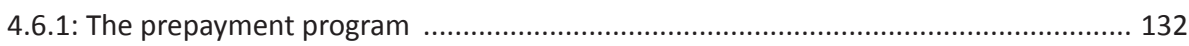

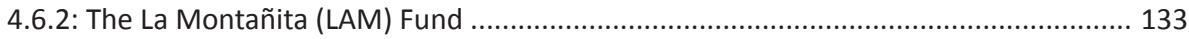

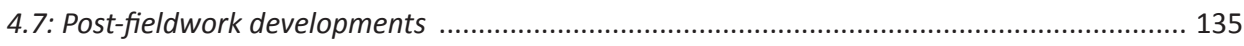

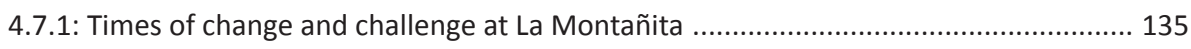

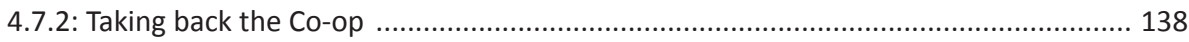

4.8: La Montañita through the lenses of embeddedness and diverse economies ...................... 140

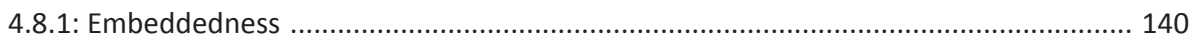

4.8.2: The diverse finance and labor economies of La Montañita Co-op ............................. 142

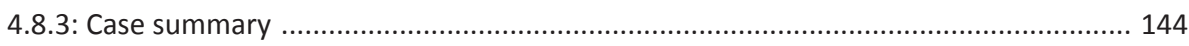

Chapter 5: Case Study of Mountain View Market Co-op .......................149

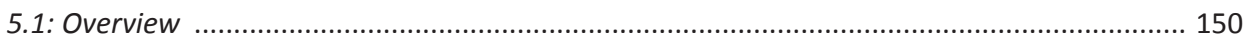

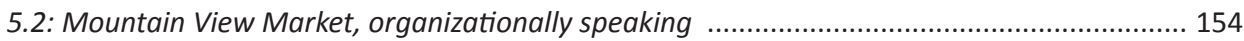

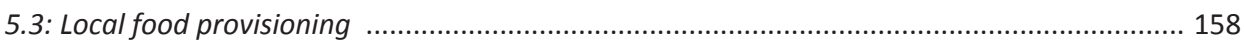

5.4: Framing local food at Mountain View Market ...................................................................... 160

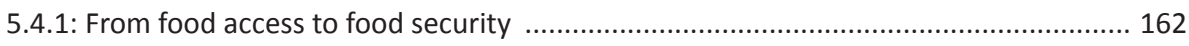

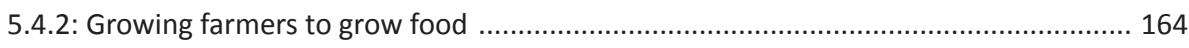




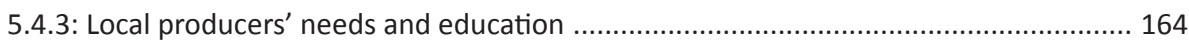

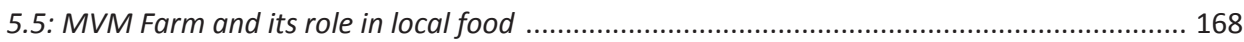

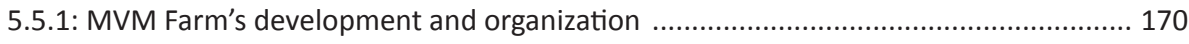

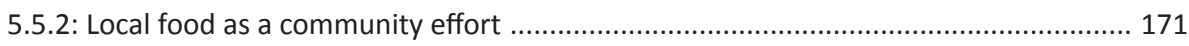

5.5.3: MVM Farm and Co-op relations as a negotiated process .......................................... 173

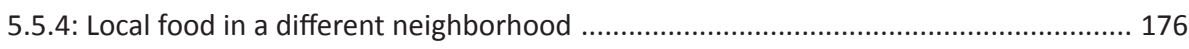

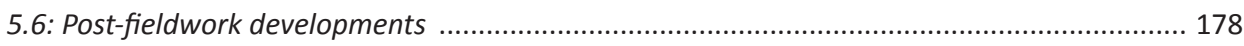

5.7: Mountain View Market through the lenses of embeddedness and diverse economies ....... 179

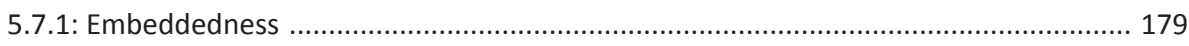

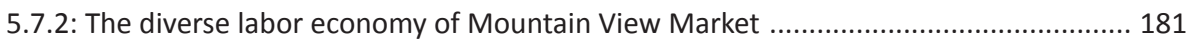

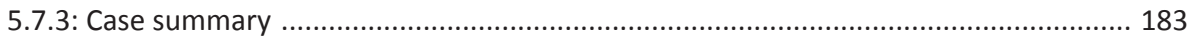

Chapter 6: Discussion and Conclusions ...............................................189

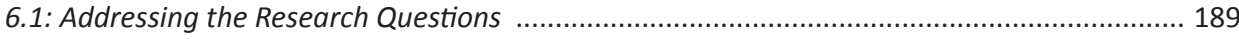

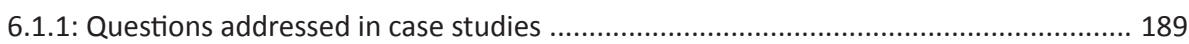

6.1.2: Competitive advantage, local food provisioning, and the cooperative difference ..... 195

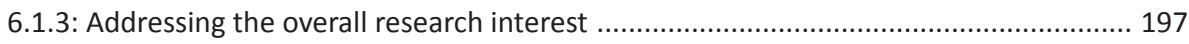

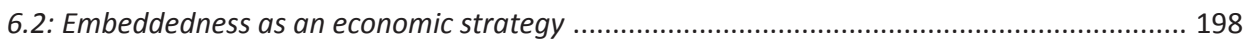

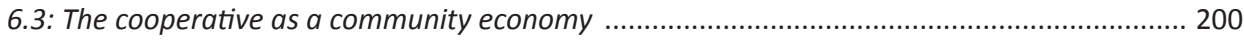

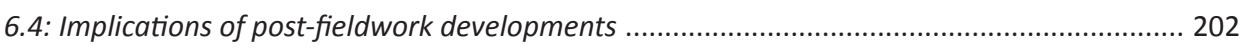

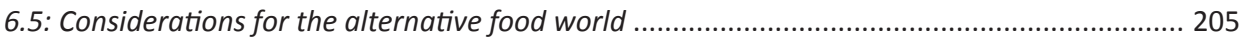

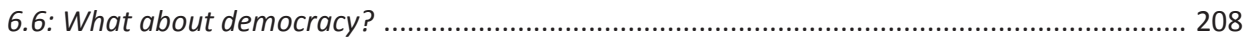

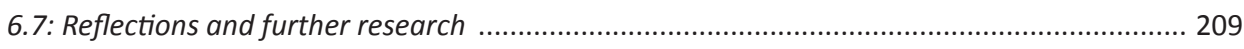

6.7.1: A reflexive view on my presence as a researcher ....................................................... 213

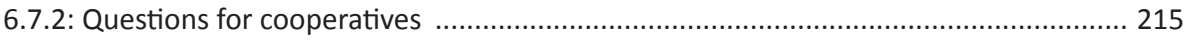

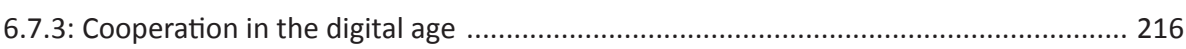

Appendices .....................................................................................221

Appendix 1: The Seven Principles of Co-operative Identity ........................................................ 222

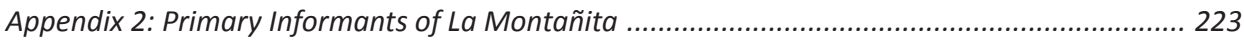

Appendix 3: Primary Informants of Mountain View Market ...................................................... 224

Appendix 4: Business strategies for local food - co-ops versus other grocers ............................ 225

NB: All URL links to web sites in this document were last accessed March 2017.

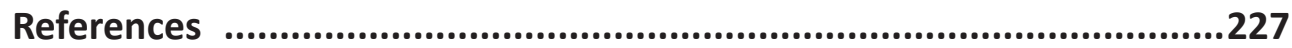

Summary.............................................................................247

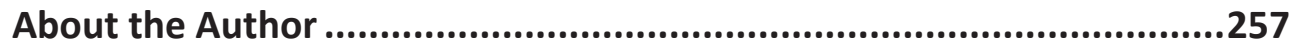





\section{Lists of Visual Elements}

Disclaimer: The presence of photographs, logos, and advertising related to the case studies of this thesis (La Montañita Food Co-op and Mountain View Market Co-op) is in no way an endorsement or specific recommendation by Wageningen University \& Research of the brands, products, companies, organizations, growers, or producers in said advertising. All such images are for illustrative purposes and are included at the sole discretion of the author for non-commercial, educational use only.

List of Advertisements

Advert 1: La Montañita ad touting link with local grower 112

Advert 2: La Montañita's distribution and backhauling network ................................................ 121

Advert 3: CDC advertising for producers and institutional customers .......................................... 124

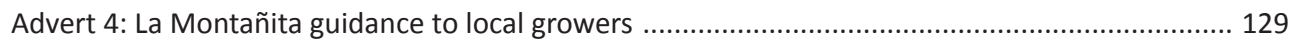

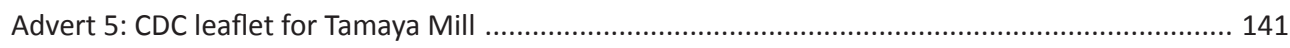

Advert 6: MVM Co-op's delivery service to other New Mexican cities and to El Paso, Texas ........... 159

Advert 7: Flyer for a vermiculture workshop at the MVM Farm .................................................. 167

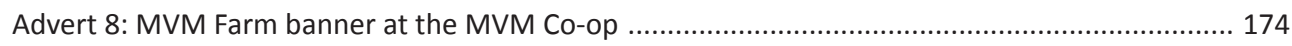

List of Maps

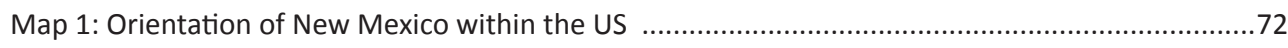

Map 2: Orientation of field site cities (Albuquerque and Las Cruces) ...............................................73

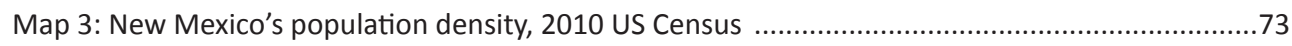

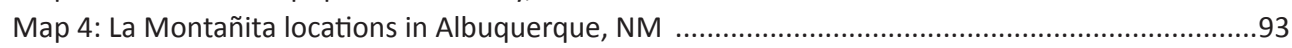

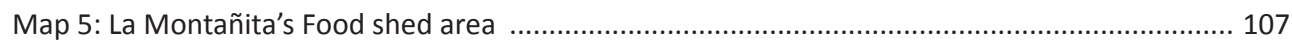

Map 6: Mountain View Market locations A) Co-op, B) Downtown Cafe, and C) Farm ...................... 155

Map 7: Orientation of Sunland Park, NM to Las Cruces (upper left) ............................................ 177

List of Figures

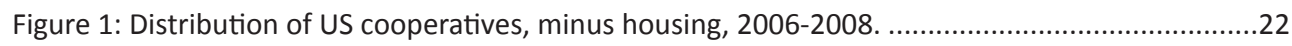

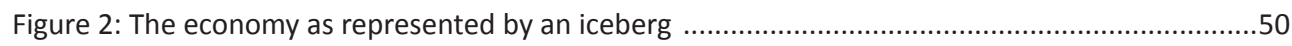

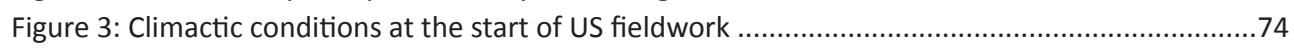

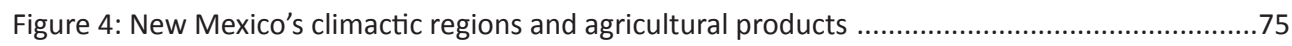

Figure 5: New Mexico's top farm commodities by cash receipts ....................................................76

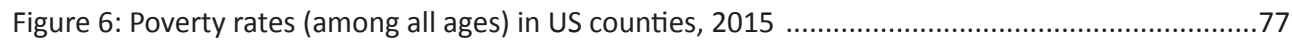

List of Tables

Table 1: Differences between cooperatives, corporations and non-profit organizations ...................12

Table 2: A sampling of member types and arrangements of retail food co-ops ...................................19

Table 3: Who is embedded in what? Different views on embeddedness .............................................41

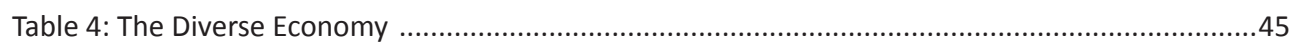

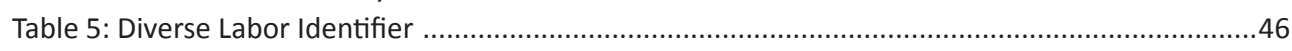

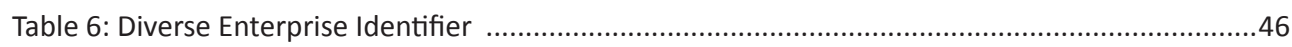

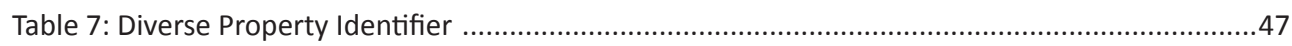

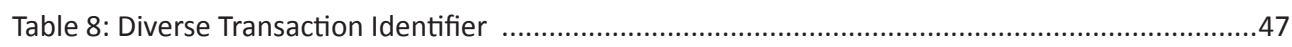

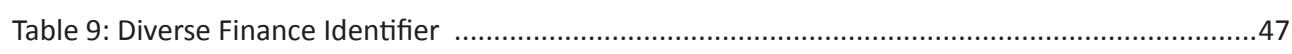

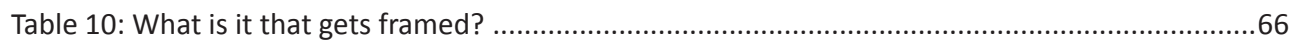


List of Photographs

Photo 1: Veteran Farmer Project space in Albuquerque .........................................................98

Photo 2: La Montañita's oldest (Nob Hill) and newest (Westside) locations ................................102

Photo 3: Four types of La Montañita produce labels .......................................................... 108

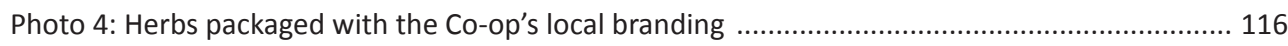

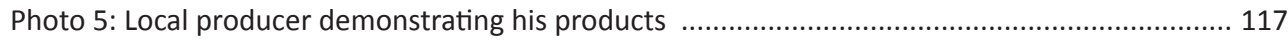

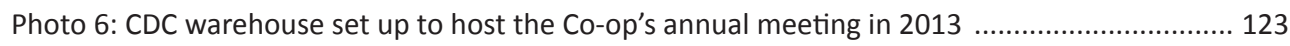

Photo 7: Produce staff receiving local delivery ............................................................. 128

Photo 8: Branding materials created by La Montañita Co-op for local suppliers ............................ 130

Photo 9: Grower displays packaging paid for by LAM Fund loan .......................................... 134

Photo 10: Mountain View Market Co-op storefront ........................................................... 151

Photo 11: Banner promoting independent businesses giving special offers to MVM members ...... 153

Photo 12: Wall mural of cooperative principles at store manager desk .................................. 154

Photo 13: Two kinds of local wheatgrass for sale at the MVM Co-op ...................................... 161

Photo 14: Local cafe with which MVM Co-op worked ........................................................ 166

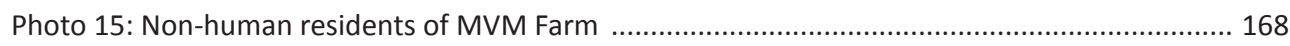

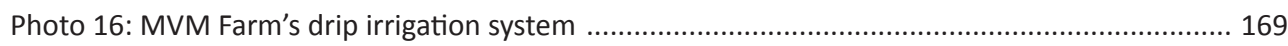

Photo 17: Flood irrigation typically used in the region (here, for pecan trees) ........................... 169

Photo 18: Farm Administrator leading a tour for school students ......................................... 182

Photo 19: MVM's GM constructing the MVM Farm's aquaculture system ............................... 184 

$4 \times 2-2+2$

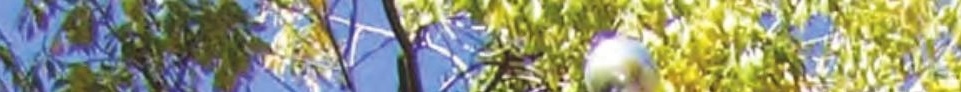


Overleaf: Flags flying over a plaza in a tourist area of Albuquerque, New Mexico's most populous city. 
This chapter introduces this thesis, which examines how cooperatives in the natural and organic sector frame the issue of local food and how they engage in it. The chapter begins with a problematization of the food system and then offers a description of the overall cooperative economy. Following that is a theorization of food cooperatives in the retail sector and a typology of cooperatives and how they can be arranged. I place food

cooperatives in a historical context regarding their development and engagement as ethical actors. Then, I pose questions about their competitive advantage and strategies in working with local food. Finally, I introduce the research questions of this thesis and describe the structure for the remainder of the work.

\section{Chapter 1: Introduction}

Food can be the ultimate co-operative product, from growing and harvesting through to marketing, cooking and sharing. ... To be co-operative is to be aware of those around you. This is true, not least, of the many hands that grow the food that nourishes you. - Ed Mayo, Secretary General of Co-operatives UK

In the middle of August 2009, terrible and damaging hailstorms swept across New Mexico, a sparsely populated state located in the desert southwest of the United States. It was prime growing and harvesting season for a number of important crops, and many farmers were affected. Growers were threatened with the loss of income from produce that would have to be plowed under as unsalable. In northern New Mexico, hail fell on apple orchards. In the southern areas of the state, pomegranate growers were affected. The crops were edible but cosmetically damaged and unmarketable, both in the retail outlets of farmers' markets and in the wholesale outlets of grocery stores.

In an effort to help growers make some income from their crops, the La Montañita Food Co-op grocery store came up with a plan. La Montañita Co-op bought and collected the pomegranate crop from farmers in the south and the apple crop from farmers in the north. It then delivered all of the fruit to a local juice bottler that it contracted to press the fruit and bottle it into juice. La Montañita Co-op had their marketing department design a label for the bottles and began selling the pomegranate-apple juice in their retail shops. This unexpected venture was a success with shoppers that year and for several seasons to follow. It also provided 


\section{6 | Chapter One}

Big B's Fantastic Juices, the local bottler, with a new product for their range that rivalled the POM pomegranate juice brand imported from California. ${ }^{1}$

Though the juice turned out to be commercially successful, there was significant work involved in bringing the project to fruition - work that would not normally be taken on by a grocery store. The efforts by La Montañita are even more remarkable considering this: the typical scenario in the food retailing world would actually see farmers - when unable to fulfill pre-existing supermarket contracts due to poor or no harvest - compelled to pay compensation for undelivered product. ${ }^{2}$ Instead, this story exemplifies something rare and restorative: collaborative efforts to re-imagine different outcomes for everyday happenings in the world's problem-ridden food systems.

Why would a retail grocery store take on such a project to help growers? Of course it turned out that it was a profitable exercise, but moreover, it matters that this grocery store is a cooperative (or co-op), which has a structural ethic to show concern for its community. In the case of La Montañita Co-op and other co-ops in food retail, one way this concern has manifested has been via engagement with local food provisioning. This has served the local community and the business interests of co-ops. It has also highlighted deeper attempts to raise awareness of and to influence the wider food system - much like civic or alternative food networks (AFNs) have. This thesis examines drivers and practices of local food engagement by looking at two cases of co-ops in the natural and organic food retail sector in the United States. Through looking at these co-ops' efforts to create more embedded and community-based food systems, I reflect on their connections with AFNs and the possible lessons that can be offered by co-ops seeking to engage in ethical action in food and agriculture - even in the face of dominant, long-distance food systems that are more driven by market capitalist exchange.

\footnotetext{
${ }^{1}$ During fieldwork, several co-op staffers mentioned this incident, a retelling of which (available at https://youtu. be/QgosYeNzBec?t=1394) was done at a conference of the California Center for Cooperative Development in April 2011. The session was taped/edited by Jai J Noire (www.YouTube.com/JJNoire) ${ }^{2}$ See https://www.foodandwaterwatch.org/sites/default/files/consolidation_buyer_power_grocery_fs_ dec_2010.pdf, http://www.ase.tufts.edu/gdae/Pubs/rp/AAl_Issue_Brief_3.pdf, and https://www.theguardian. com/environment/2011/jul/02/british-farmers-supermarket-price-wars, for information about unfair abuses of supermarket buyer power.
} 


\section{1: Problematizing the food system}

Despite the advances of post-WWII global food production, the number of undernourished people in the world crossed the one billion mark in 2009 (FAO). Though that number had declined to just under 800 million in $2015,{ }^{3}$ trends in dietary transitions (especially people eating more processed food, meat, and dairy products), water shortages, and climate change promise continued and even greater threats to food security. Agricultural processes and production methods have damaged landscapes and habitats and created environmental problems (Magdoff et al. 2000). Food processing, distribution, and marketing tactics have helped to create epidemic proportions of overweight and obese children and adults worldwide (Pollan 2010; Nestle 2003). Farming income, in both rich and poor countries, has decreased in real terms for decades, as consolidation at all levels of production and processing has homogenized tastes and driven out smallholders (Lang and Heasman 2004; Tansey and Worsley 1995). So while the triumph of the globalized, industrial food system has allowed food to be produced cheaply, widely, and abundantly, many costs have been externalized in the process.

Alternative food movements - also referred to as alternative food networks (AFNs) or alternative agro-food networks (AAFNs) - have proliferated rapidly (Amin 2011; Belasco 2007; Pollan 2010) in many countries of the global north, where industrialization of the food system has had longest to take hold. These food movements offer a broad critique of the global food regime, and the proliferation of such movements shows the desire of groups and individuals to engage with the food system differently. Though characterizing alterity in the food system is contentious and not the focus of this work, Whatmore et al. have proposed that AFNs" "constitution as/of food markets that redistribute value through the network against the logic of bulk commodity production; that reconvene 'trust' between food producers and consumers; and that articulate new forms of political association and market governance" to be general commonalities among them $(2003,389)$.

Cox et al. describe AFNs as referring "to food production - consumption practices of any scale which present possibilities for producing/consuming food in ways that differ from those typical in industrialised food systems" $(2008,205)$. Though such a definition importantly offers some utility and incorporates downstream and upstream action, as highlighted by Tregear, defining a movement by what it

${ }^{3}$ See http://www.fao.org/news/story/en/item/288229/icode/ for further details. 
is not (rather than by what it is) is "problematic" for several reasons $(2011$, p. 6). Doing so conjures a binary distinction that lends little to efforts to elucidate the breadth of actions and initiatives that are described in the academic literature on AFNs. Various scholars have also pointed out that the practices of alternative versus conventional food systems are often much more closely aligned than rhetoric would suggest (Holloway et al., 2007; Sonnino \& Marsden, 2006). While, pragmatically speaking, alternative food movements are concerned with providing different ways for people to eat on a day-to-day basis (Hassanein 2003), these movements also embody the desire to create structural change at different levels of the food system (Magdoff et al. 2000; Seyfang and Smith 2006), as reflected in La Via Campesina's call to remove food from international trade regimes (Rosset 2006). As such, ideas of local participation and devolved control of food and agriculture are powerful drivers and central points of expression in the alternative food movement.

An important part of the discussion about the interest in alternative food is that - by diversifying and democratizing food provisioning by including different and non-dominant actors, products, and ways of doing business - they may bring more resilience into food systems during times of economic or environmental crisis (King 2008; Lang 2010; Mulqueen 2012; Thompson and Scoones 2009). Academic literature on alternative food networks concerned with local food has mainly focused on farmers' markets and community-supported agriculture (CSA) operations, as these outlets are a direct market between consumers and producers (Renting et al. 2003; Sage 2003; Watts et al. 2005; Whatmore et al. 2003). Relatively little work has showcased the place of retail co-ops in deepening local food provision. This is despite co-ops' interest, history, and credibility in sourcing local food (Katchova and Woods 2011) and their competitive advantages in local food provisioning (Katchova and Woods 2013; Lake and Leviten-Reid 2015). This represents a blind spot in the literature on AFNs.

By their very nature of organization (ownership by their employees and/or customers) and by their emphasis on inclusive decision making, cooperatives may provide a ready outlet for manifesting different ways of production, distribution, and consumption from what is provided through the conventional food system described by Friedmann (1993b). As such, this research positions cooperative businesses as potential change agents in food provisioning - not despite, but because of - their expertise and involvement in economic exchange. The following 
section offers a theorization of cooperatives to explicate how their form reflects alterity.

\section{2: Defining cooperatives}

Working cooperatively does not make an enterprise a cooperative. ${ }^{4}$ This is a false assumption that the International Co-operative Alliance (ICA), the foremost global apex and advocacy group for cooperatives is trying to correct. The ICA offers a basic definition of cooperatives as jointly-owned and democratically-controlled enterprises through which people unite "voluntarily to meet their common economic, social, and cultural needs and aspirations" (International Co-operative Alliance 1995). This definition defines cooperatives as businesses, and across the world this takes many shapes. As a cooperative is simply a business form, it is not limited to food and agriculture. Indeed, co-ops are found in all sectors and play important roles in economies worldwide. From (non-food) consumer retail co-ops such as REI sporting goods in the United States, to the FC Barcelona football club in Spain, to the dairy co-op FrieslandCampina based in the Netherlands, to the Coopamare waste pickers and informal recyclers in Brazil, "co-operatives are owned by nearly one billion people across the globe, employ nearly 100 million people - 20 per cent more than multinational enterprises - and is the model that is on track to become the fastest growing business model by 2020" (Barker et al. 2012). Agriculture and food, banking and financial services, and insurance account for the largest share of turnover in all cooperative sectors by far (71\%), and consumer food retail that is the subject of this research is a small sliver of the $19 \%$ representing wholesale and retail (Euricse 2016).

People and organizations become members of cooperatives for a range of reasons that they find beneficial (economic, social, and political). According to Lawless (2003), cooperatives' philosophies might be described as emerging from one of two perspectives: either an ideological movement with utopian aspirations (idealist perspective) or an economic tool that is useful for particular conditions rather than a panacea (pragmatist perspective). Cooperatives have a long history of maintaining

\footnotetext{
${ }^{4}$ Multiple spellings and shortenings of "cooperative" are used in this document, though the unhyphenated form appears most often when the full word is used. This is the predominant form in the US, where the fieldwork took place. When referencing organizations that employ the hyphen in their names or in documentation - or when quoting text that originally used the hyphenation - the original form has been retained. Also, as co-ops were originally organized into groups called "societies," that term alone may appear infrequently in this thesis to mean a co-op.
} 
or creating options for people and communities left behind by market failure. (See section 1.5 of this thesis.) Cooperatives are often formed when communities lack basic goods or services that they desire, as typified by the historical development of electric cooperatives in the United States (Lowery 2010). There is, however, a strain of cooperative development that is more ideals-driven when co-ops are formed to access a different kind of provision, versus not having any provision at all (e.g., forming an organic co-op with sustainable food in an area where there are already extant, conventional grocery shops).

Some differences that emerge from these conditions have been discussed by Lake and Leviten-Reid (2015), particularly regarding the implications of local food sourcing. It is important to note, however, that despite a cooperative's or cooperative sector's conceptions of markets and cooperative philosophy, cooperatives as a whole do not contradict the aims of market capitalism (Zeuli and Cropp 2004), but rather they subordinate its supremacy by limiting returns on investment and prizing democratic control (Birchall 1997). Still, the relationship of cooperatives to markets and capitalism remains a rather contested one (Battilani and Schröter 2012; Whyman 2012; Novkovic 2008). Deller et al. offer this distinction between cooperatives and classically investor-controlled firms:

"Traditionally, the defining characteristics of a cooperative business are that the interests of the capital investor are subordinate to those of the business user, or patron, and returns on capital are limited. Cooperative control is in the hands of its member-patrons, who democratically elect the board of directors. Member-patrons are the primary source of equity capital, and net earnings are allocated on the basis of patronage instead of investment." $(2009,4)$

Additionally, the ICA, though revisions and consultations with its membership (last in 1995) has elaborated a "Statement on the Co-operative Identity" embodying the ideals and practices that are generally agreed by cooperatives worldwide. They are commonly referred to as "principles" and are seen as guidelines for cooperatives to put their values into practice. These are (1) open, voluntary membership; (2) democratic control by members; (3) economic participation from members; (4) organizational autonomy and independence; (5) education of members and public about cooperatives; (6) cooperation among cooperatives; and (7) concern for 
community. ${ }^{5}$ Though the seven principles are not to be thought of as a pick-andmix assortment to which cooperatives can ascribe, cooperatives make operational decisions based on their own emphasis on and interpretation of the ICA principles and the interests and needs of their members. Indeed, the broader cooperative movement can embody both extremes of an issue, such as the climate change denial in rural electricity co-ops versus the vocal advocacy for clean energy in renewable energy co-ops. ${ }^{6}$

Lest it be presumed that cooperative enterprises are marginal or particularly radical, it is crucial to understand their influence (especially in consumer retail) in various countries. In the European context, many cooperative retail societies are market leaders or among the top three retailers in their countries. Members of EuroCoop (a consortium of consumer cooperatives - the secretariat of which is based in Brussels) account for more than $€ 79$ billion in sales, and one of every five people in EU-member countries in Europe is a member of a cooperative. ${ }^{7}$ Although the iconic UK Co-op Group has suffered some very difficult times in the last years, until 2014, it owned Britain's largest farming operation. It was also the UK's fifth-largest food retailer until $2017 .{ }^{8}$ Cooperatives are varied in size, structure, and expression of political ethos and may include enterprises of all sizes. The table below discusses some important attributes of cooperatives and how they work - as opposed to corporations and non-profit organizations.

\footnotetext{
${ }^{5}$ Information about the seven principles of co-operative identity may be found at http://ica.coop/en/whatco-operative. See also a fuller explanation in the Appendices of this work.

${ }^{6}$ Significant amounts electricity purchased by rural electric co-ops comes from coal-fired power plants. For further discussion of this issue see http://rappnews.com/2015/09/24/are-electric-co-ops-switching-off-climatechange/144865/ and also http://www.climatesciencewatch.org/2010/10/20/virginia-maryland-delaware-electricco-ops-climate-change-deception/

${ }^{7}$ See the website for EuroCoop at http://www.eurocoop.coop/about-us/About/ and also the 2015 key statistics report for Cooperatives Europe, the European office of the ICA at https://coopseurope.coop/resources/ news/140-million-european-citizens-are-members-cooperative-\%E2\%80\%93-new-report-released ${ }^{8} \mathrm{~A}$ litany of woes has beset the UK Co-op Group, from personal scandals in executive behavior https://www. theguardian.com/world/2017/jan/16/former-co-op-bank-chair-paul-flowers-dismissed-from-church-over-drugs to loss of market share to discount retailers https://www.theguardian.com/business/2017/feb/07/aldi-uk-fifthlargest-supermarket to inadequate capitalization of its banking operation prompting a bailout in 2013 and a sale in 2017 https://www.theguardian.com/business/2017/feb/13/for-sale-co-op-bank-looks-for-buyers
} 


\section{2 | Chapter One}

Table 1: Differences between cooperatives, corporations and non-profit organizations ${ }^{9}$

\begin{tabular}{|c|c|c|c|}
\hline Attributes & Co-operatives & $\begin{array}{l}\text { Investor-Owned } \\
\text { Corporations }\end{array}$ & $\begin{array}{l}\text { Non-profit } \\
\text { Organizations }\end{array}$ \\
\hline Ownership & Member-owned & Investor-owned & $\begin{array}{l}\text { Generally not } \\
\text { "owned" by a person } \\
\text { or members }\end{array}$ \\
\hline Control & $\begin{array}{l}\text { Democratically controlled; } \\
\text { one vote per member, equal } \\
\text { voice regardless of their } \\
\text { equity share. Members are } \\
\text { involved in the day-to-day } \\
\text { business operations and re- } \\
\text { ceive services for their input. }\end{array}$ & $\begin{array}{l}\text { Controlled by share- } \\
\text { holders according to } \\
\text { their investment share. } \\
\text { Business decisions and } \\
\text { policy are made by a } \\
\text { board of directors and } \\
\text { corporate officers. }\end{array}$ & $\begin{array}{l}\text { May be controlled by } \\
\text { members who elect a } \\
\text { board of directors or, } \\
\text { in non-membership } \\
\text { organizations, the } \\
\text { board of directors } \\
\text { may elect its own } \\
\text { successors. Control is } \\
\text { maintained by those } \\
\text { not receiving the } \\
\text { services. }\end{array}$ \\
\hline $\begin{array}{l}\text { Board } \\
\text { membership } \\
\text { and } \\
\text { compensation }\end{array}$ & $\begin{array}{l}\text { Made up of co-op members } \\
\text { elected by the members. } \\
\text { Usually, they do not work for } \\
\text { the co-op. Cost reimbursed } \\
\text { for board meetings. Board } \\
\text { members usually serve on an } \\
\text { uncompensated, volunteer } \\
\text { basis. }\end{array}$ & $\begin{array}{l}\text { Board is composed } \\
\text { of a combination of } \\
\text { independent directors, } \\
\text { management and other } \\
\text { directors with financial } \\
\text { or business ties to the } \\
\text { organization. CEOs may } \\
\text { serve as the board chair. } \\
\text { Significant financial com- } \\
\text { pensation is provided for } \\
\text { board service. }\end{array}$ & $\begin{array}{l}\text { Board is generally } \\
\text { made up of people } \\
\text { who do not receive } \\
\text { the services, usually } \\
\text { chosen for philan- } \\
\text { thropic or political } \\
\text { reasons. Board mem- } \\
\text { bers usually serve on } \\
\text { a volunteer basis. }\end{array}$ \\
\hline $\begin{array}{l}\text { Board } \\
\text { nominations } \\
\text { and elections }\end{array}$ & $\begin{array}{l}\text { Candidates nominated by } \\
\text { membership either directly, } \\
\text { or by a nominating commit- } \\
\text { tee made up of members. } \\
\text { Usually, any member can } \\
\text { nominate a director can- } \\
\text { didate. Board is elected by } \\
\text { the members (one vote per } \\
\text { member). }\end{array}$ & $\begin{array}{l}\text { Candidates nominated } \\
\text { by the board of directors } \\
\text { and management, } \\
\text { often by a nominating } \\
\text { committee. Sharehold- } \\
\text { ers have limited ability } \\
\text { to nominate and elect } \\
\text { director candidates. }\end{array}$ & $\begin{array}{l}\text { Either by members } \\
\text { or the board of } \\
\text { directors. }\end{array}$ \\
\hline
\end{tabular}

\footnotetext{
${ }^{9}$ Adapted from a 2007 factsheet of the US Overseas Cooperative Development Council available at https://ica. coop/sites/default/files/Factsheet\%20-\%20Differences\%20between\%20Coops\%20Corps\%20and\%20NFPs\%20 -\%20US\%200CDC\%20-\%202007.pdf
} 


\begin{tabular}{|c|c|c|c|}
\hline Attributes & Co-operatives & $\begin{array}{l}\text { Investor-Owned } \\
\text { Corporations }\end{array}$ & $\begin{array}{l}\text { Non-profit } \\
\text { Organizations }\end{array}$ \\
\hline Accountability & $\begin{array}{l}\text { The board is directly account- } \\
\text { able to members through } \\
\text { nomination and election } \\
\text { procedures. }\end{array}$ & $\begin{array}{l}\text { Board election and } \\
\text { nomination procedures } \\
\text { afford little oversight } \\
\text { opportunity to share- } \\
\text { holders. Shareholders } \\
\text { not likely to be able to } \\
\text { remove board members. }\end{array}$ & $\begin{array}{l}\text { Generally account- } \\
\text { able to members of } \\
\text { the organization and } \\
\text { those who provide } \\
\text { the funding to the } \\
\text { organization. }\end{array}$ \\
\hline $\begin{array}{l}\text { Earnings or } \\
\text { dividends }\end{array}$ & $\begin{array}{l}\text { Any surplus revenues (profits) } \\
\text { earned by the co-op are rein- } \\
\text { vested in the business and/or } \\
\text { returned to members based } \\
\text { on how much business they } \\
\text { conducted with the co-op } \\
\text { that year. This is a patronage } \\
\text { rebate. Many co-ops are } \\
\text { obligated to return a portion } \\
\text { of their "surplus revenues" } \\
\text { to members each year. Mem- } \\
\text { bers share losses or earnings. }\end{array}$ & $\begin{array}{l}\text { Profits returned to } \\
\text { shareholders based on } \\
\text { ownership share. Cor- } \\
\text { porations are generally } \\
\text { not obligated to pay out } \\
\text { dividends. Timing and } \\
\text { amount of dividend pay- } \\
\text { out are determined by } \\
\text { the board of directors. }\end{array}$ & $\begin{array}{l}\text { Re-invest any profits } \\
\text { they make in their } \\
\text { public benefit pur- } \\
\text { pose and their own } \\
\text { operations. }\end{array}$ \\
\hline $\begin{array}{l}\text { Purpose or } \\
\text { motivation }\end{array}$ & $\begin{array}{l}\text { Maximize customer service } \\
\text { and satisfaction. } .^{10}\end{array}$ & $\begin{array}{l}\text { Maximize shareholder } \\
\text { returns. }\end{array}$ & $\begin{array}{l}\text { Primary motivation is } \\
\text { to serve in the public } \\
\text { interest. Redistrib- } \\
\text { ute resources to } \\
\text { provide educational, } \\
\text { charitable and other } \\
\text { services. }\end{array}$ \\
\hline $\begin{array}{l}\text { Source of } \\
\text { funds or } \\
\text { generation of } \\
\text { money }\end{array}$ & $\begin{array}{l}\text { Raise resources through the } \\
\text { equity of members: } 1 \text { ) direct } \\
\text { investment; } 2 \text { ) retained mar- } \\
\text { gins; and 3) per- unit capital } \\
\text { retains (capital investments } \\
\text { based on the number of } \\
\text { physical units handled by the } \\
\text { co-op or on a percentage of } \\
\text { sales). }\end{array}$ & $\begin{array}{l}\text { Typically raise money } \\
\text { through capital markets. }\end{array}$ & $\begin{array}{l}\text { Typically funded by } \\
\text { donations from the } \\
\text { private or public } \\
\text { sector or the govern- } \\
\text { ment. Tax-exempt. }\end{array}$ \\
\hline Community & $\begin{array}{l}\text { Promote and assist communi- } \\
\text { ty development. }\end{array}$ & $\begin{array}{l}\text { May engage in selected } \\
\text { community philanthrop- } \\
\text { ic activities. }\end{array}$ & $\begin{array}{l}\text { Offers mechanisms } \\
\text { for collective action } \\
\text { based on a common } \\
\text { good. }\end{array}$ \\
\hline
\end{tabular}

\footnotetext{
${ }^{10}$ Authors' note: I disagree with this characteristic. All co-ops exist to serve their members' needs, regardless of their business sector. This description seems only to consider consumer cooperatives.
} 


\section{3: Understanding food cooperatives - past and present}

It is instructive to understand the birth of the cooperative movement in order to contextualize food cooperatives. Interest in cooperative societies has ebbed and flowed over time, but what has come to be understood as a worldwide movement across all sectors of trade actually began with food in Rochdale, England. Cooperatives and mutual societies were not actually a new idea at the time. Cooperative societies had spread across the UK and Ireland in various sectors, but many had collapsed by the 1830s due to economic downturns and poor governance and business practices (Birchall 1997, 3).

In December 1844, however, the Rochdale Society of Equitable Pioneers - made up of 28 skilled weavers and associated tradesmen - came together to open a mutually-owned shop after saving money collectively for over a year. The Pioneers had founded a cooperative society and had specific aims of opening a shop where members could purchase basic foodstuffs that were difficult to find affordably and in good quality via the company store of the mills where they worked. ${ }^{11}$ The Pioneers first sold only basic items to their members (butter, flour, oats, candles, and sugar) from the shop that was open two nights per week. Within three months, trading hours increased to four nights per week, and the product range was expanded. According to the Rochdale Pioneers' Museum web site, within a year, there were 74 members. By 1850, the Pioneers' prosperity began attract notoriety and visitors from all over the world who wanted to emulate the model. While they were not the first of their kind, the Pioneers' contribution the cooperative movement was to establish and codify principles that helped guide the development of cooperatives worldwide (Zeuli and Cropp 2004). Given that the shop stocked goods such as flour - which was often heavily adulterated at that time - it is little wonder that trade in pure, unadulterated goods was one of their nine founding principles. ${ }^{12}$

Today, there are many examples of cooperative farms, restaurants, bakeries, and other food-related enterprises, but this work focuses on retail food shops in the cooperative economy that are (or are most analogous to) grocery shops and

\footnotetext{
${ }^{11}$ The story of the Pioneers and the opening of the shop on Toad Lane has become a signifying moment for the cooperative movement, and a museum was opened on its defunct site in 1931. It underwent significant remodeling and refurbishment that was completed in 2012, the UN Year of the Cooperative. See http:// strongertogether.coop/food-coops/history-of-co-ops and also http://www.rochdalepioneersmuseum.coop/

12 There were originally nine co-operative principles established by the Rochdale Pioneers, but there are now seven recognized by the International Co-operative Alliance and subscribed to by co-ops worldwide. They have been revised at different intervals over time. http://www.rochdalepioneersmuseum.coop/about-us/therochdale-principles/
} 
supermarkets. Cooperatives in food retail range widely in operations: from a single storefront selling conventional food brands, to several outlets selling natural and organic foods, to multi-billion euro operations with hundreds of outlets selling a mix of conventional and ethical products of various kinds. Some cooperatives sell items that others would refuse to sell, like cigarettes and alcohol. It is important to note that - even in the US where cooperative food shops are highly represented in the natural and organic food sector, with over $82 \%$ of produce and $48 \%$ of shelfstable grocery items sold being organic ${ }^{13}$ - co-ops can sell whatever types of foods their members want and customers will buy. Such is the case with Renaissance Community Co-op, which officially opened in October 2016 in North Greensboro, North Carolina. In 1998, this working class community had lost its last full-service grocery shop, which was a retail anchor to many other local business. After 18 years as a food desert suffering economic blight and other challenges, the community was able to organize to develop and open a food co-op. It does not feature organic food, although it is a cooperative with over 1000 owners and a growing sense of community agency. It sells conventional food, but it is not a conventional grocery shop. ${ }^{14}$

Deller et al. (2009) discuss how cooperatives work very differently from a traditional grocery shop. In food retail in the United States, the consumer-owned cooperative is the dominant cooperative model. Customers can become members by paying an amount of money representing a membership share that serves as an equity investment in the co-op. Afterward, there may be annual or otherwise periodic contributions required to continue on as a member. The rules can differ between co-ops, but modern food co-ops usually allow both non-members and members to purchase goods - but on different terms or at different costs. There are also different tax arrangements on income earned by the cooperative, depending on whether it is derived from members or from non-members.

Though it was rather common in the 1960s and 70s, most consumer cooperatives in the US no longer offer different tiers of membership or purchasing discounts in exchange for members' contributions of labor to operate the shop. However,

\footnotetext{
${ }^{13}$ Though organic food is widely available in many conventional retail outlets, such food makes up only $12 \%$ of produce sales and $2 \%$ of grocery items at conventional grocery stores. http://www.strongertogether.coop/foodcoops/food-co-op-impact-study

${ }^{14}$ The story of Renaissance Community Co-op can be found at https://renaissancecoop.com/2016/11/04/morethan-a-grocery-store/
} 
there are often specific discounts and sales offered to all members across the board. Additionally, most cooperatives in the US now employ professional staff and management, rather than relying on members' labor. ${ }^{15}$ If a cooperative has done well financially in a given year, the board and management can collaboratively decide whether a patronage rebate (a rebate which is based on the amount of custom) can be given to the membership. In addition to the financial incentives of membership, members are able to run for election to the Board and to vote on various matters on a one vote per member basis.

Though they have some commonality of form (being owned by their members and using democratic decision making), cooperatives are not monolithic in any sense. They may actively promote or may actively downplay their cooperative nature, even eschewing the name cooperative altogether. Many grocery shops that are cooperatives do not use this word to describe themselves. Instead they might just call themselves a community market or grocer(y). For example, the largest consumerowned food retail cooperative in the United States has over 45,000 members at nine locations in the Puget Sound area of the Pacific Northwest. Though it grew out of a buying club that begun in 1953, and there is significant information on one section of its website describing it as a cooperative, it popularly uses the name PCC Natural Markets and has done so for years.

\section{4: Cooperative typologies}

As there are many types and forms of cooperatives, and multiple terms may be used to describe them, defining the myriad of legal forms and governance structures in the cooperative movement is a complex task - one precluded here by space limitations. As such, I shall offer a brief description of the typologies frequently seen in retail food cooperatives. ${ }^{16}$ While some of the specific examples below may use sectors outside of food retail, they all have forms that may be found in food retail.

\footnotetext{
${ }^{15}$ This development has come from the desire to professionalize and bring stable jobs to co-op communities and has evolved amid fears of labor violations and legal rulings against volunteering in exchange for shopping discounts at co-ops. See http://www.eastendfood.coop/archives/6993 for a comprehensive discussion of this issue.

${ }^{16}$ For a comprehensive discussion on the financial and legal issues and the governance approaches used in the UK cooperative economy, consult Co-operatives UK http://www.uk.coop/co-operatives. Though the US has a national advocacy body, the organization of co-ops by state has makes such a comprehensive one not possible.
} 


\section{Cooperative Degree}

Primary (or first degree) cooperatives are owned directly by a group of people. Secondary (or second degree) cooperatives are owned by a group of primary cooperatives. Tertiary (or third degree) cooperatives are owned by a group of secondary cooperatives. Several of the leading cooperative apex (advocacy) organizations in both the US and Europe are examples of secondary cooperatives. Co-operatives UK, the self-described "guardian of co-operative identity" in the UK, is one example. There are also business-to-business services groups that are secondary cooperatives, such as National Cooperative Grocers (NCG), a business services co-op whose members are in the natural and organic foods retail sector. The cooperative degree is mainly important regarding governance models of representation and voting, as ownership denotes the decision-making power. In food retail cooperatives, primary cooperatives - and to a much lesser extent, secondary cooperatives - are the predominant form.

An interesting example is the UK Co-operative Group, which has a very large food operation along with four other businesses. The owners of the UK Co-operative Group are the 18 regional "independent society" consumer cooperatives - all primary cooperatives - along with approximately five million individual customer members. Members are represented via a 100-person members' council of which 15 members are elected by and from the independent societies. The remaining 85 are elected by and from the Group's individual members. ${ }^{17}$ This makes the UK Co-operative Group a primary and a secondary cooperative at the same time. The size and processes used by the UK Co-operative Group, among other reasons, make it a suis generis case. Though it will not be the basis for further discussion in this thesis, it is one example of a configuration of representative democracy at a very large scale.

\section{Member-Owner Type}

This is the most-often used category to describe a co-operative. The members (or member-owners) of a cooperative actually own (jointly) that cooperative. As such, cooperatives are generally described according to the role of their member-owners.

\footnotetext{
${ }^{17}$ These regionally based primary co-operatives are often called "the independents" by people in the UK co-op world. Though many of them use the same corporate branding of the UK Co-operative Group based in Manchester, UK; are part of joint purchasing and distribution arrangements; and are also members of the Co-operative Group; their individual members do not themselves have an individual memberships of the UK Co-operative Group. They are therefore different from the individual members of the UK Co-operative Group.
} 
The members may be the customers or users of a business's goods or services. They may provide the goods or services on offer. They may be the employees or laborers who work in that business. In food retail, cooperatives are usually either worker or consumer (customer) cooperatives. Worker cooperatives may or may not have a separate board of directors and can have varying processes for democratic participation and management. In the predominant model of a consumer cooperative in the US, there is usually paid staff, a general manager, and a board of directors. (This also describes co-operatives in many sectors. While there are many consumer cooperatives in the food sector, consumer co-operatives are not limited to food businesses.)

Additionally, there are multi-stakeholder (or hybrid) cooperatives, which may be primary, secondary, or tertiary cooperatives composed of stakeholders involved at different steps or at different levels of an activity. In the food world, one configuration of a multi-stakeholder cooperative might be growers or producers, restaurateurs, and catering companies all jointly owning the business. While the multi-stakeholder cooperative form is only about 30 years old, it is the fastest growing form in Quebec, Canada (a region full of cooperatives) and has received a great deal of attention in the European and American cooperative movements (Lund, 2012, p. 1). It has also been found in the social cooperative model pioneered in Italy in the early 1990s. This form is also conducive to forming community-based organizations, as they exemplify reciprocity and interdependence by building on the roles and functions of different stakeholders within the cooperative (Girard and Langlois 2009, 230-231).

Cooperatives have also been known to shift and modify their management configurations over time in response to their own members' wishes and the trading environment. For example, it is possible to find cooperatives that were closed to the public when established but which later became open to all. Likewise, some cooperatives began as worker cooperatives but became consumer cooperatives, and vice versa. See the table below for examples of membership arrangements of food retail cooperatives. 
Table 2: A sampling of member types and arrangements of retail food co-ops ${ }^{18}$

\begin{tabular}{|c|c|c|c|c|}
\hline & \multirow{2}{*}{$\begin{array}{l}\text { Worker Co-op } \\
\text { Unicorn Grocery } \\
\text { Manchester } \\
\text { United Kingdom }\end{array}$} & \multirow{2}{*}{$\begin{array}{l}\text { Multi-Stakeholder } \\
\text { Co-op } \\
\text { Weavers Street Market } \\
\text { Carrboro, North Car- } \\
\text { olina } \\
\text { United States }\end{array}$} & \multicolumn{2}{|l|}{ Consumer Co-op } \\
\hline & & & $\begin{array}{l}\text { Davis Food Co-op } \\
\text { Davis, California } \\
\text { United States }\end{array}$ & $\begin{array}{l}\text { Dublin Food } \\
\text { Co-op } \\
\text { Dublin, Ireland }\end{array}$ \\
\hline Format & $\begin{array}{l}\text { Full service } \\
\text { grocery shop } \\
\text { with bulk foods, } \\
\text { deli counter } \\
\text { and wine/beer } \\
\text { section. Vegan } \\
\text { products only. } \\
\text { One location. } \\
\text { Open to public. }\end{array}$ & $\begin{array}{l}\text { Full service grocery } \\
\text { shop in } 3 \text { different loca- } \\
\text { tions. Also one Italian } \\
\text { restaurant offering } \\
\text { "locally-sourced natural } \\
\text { food" called Panzanella } \\
\text { close to flagship shop } \\
\text { location. All open to } \\
\text { public. }\end{array}$ & $\begin{array}{l}\text { Full service } \\
\text { grocery shop } \\
\text { with bakery, bulk } \\
\text { foods, deli count- } \\
\text { er, and wine/ } \\
\text { beer section. } \\
\text { One location. }\end{array}$ & $\begin{array}{l}\text { Vegetarian } \\
\text { market open } \\
\text { twice-weekly } \\
\text { offering whole- } \\
\text { foods, and pro- } \\
\text { duce and stalls } \\
\text { selling artisan or } \\
\text { local items from } \\
\text { producer-owners. } \\
\text { Themed markets } \\
\text { each Sunday. }\end{array}$ \\
\hline $\begin{array}{l}\text { Number of } \\
\text { Members }\end{array}$ & $\begin{array}{l}45 \text { members } \\
\text { working in all } \\
\text { areas of the } \\
\text { shop, with some } \\
\text { limited special- } \\
\text { ization }\end{array}$ & $\begin{array}{l}15,000 \text { consumer mem- } \\
\text { bers and } 150 \text { worker } \\
\text { members, of } 260 \text { work- } \\
\text { ers in total according to } \\
2012 \text { annual report }\end{array}$ & $\begin{array}{l}\text { About } 10,000 \\
\text { households, with } \\
\text { smaller percent- } \\
\text { age as working } \\
\text { members giving } \\
2 \text { hours labor per } \\
\text { month }\end{array}$ & $\begin{array}{l}\text { About } 30 \text { pro- } \\
\text { ducer members } \\
\text { attending special } \\
\text { Sunday markets } \\
\text { and over } 800 \\
\text { other members }\end{array}$ \\
\hline $\begin{array}{l}\text { Joining } \\
\text { Fees and } \\
\text { Processes }\end{array}$ & $\begin{array}{l}\text { Most people } \\
\text { start as causal } \\
\text { staff and have } \\
\text { a probationary } \\
\text { period. Mem- } \\
\text { bership com- } \\
\text { mittee requests } \\
\text { feedback from all } \\
\text { workers before } \\
\text { taking on a new } \\
\text { member }\end{array}$ & $\begin{array}{l}\text { Consumer owners pay } \\
\text { for a share, price based } \\
\text { on the number of } \\
\text { adults per household: } \\
\$ 75 \text { one adult; } \$ 135 \\
\text { two adults; } \$ 175 \text { three } \\
\text { or four adults. Share } \\
\text { price fully refundable } \\
\text { on demand. } \\
\text { Worker members apply } \\
\text { through a separate } \\
\text { process }\end{array}$ & $\begin{array}{l}\text { California ad- } \\
\text { dress needed. } \\
\text { \$5, with } \$ 10 \text { first } \\
\text { share invest- } \\
\text { ment and } \$ 20 \\
\text { expected each } \\
\text { year, up to } \$ 300 ; \\
\text { shares may be } \\
\text { withdrawn upon } \\
\text { resignation of } \\
\text { membership }\end{array}$ & $\begin{array}{l}€ 25 \text { with } 50 \% \\
\text { discount for } \\
\text { concessions } \\
\text { (low waged and } \\
\text { unemployed) }\end{array}$ \\
\hline
\end{tabular}

${ }^{18}$ All figures, prices, staff numbers, and operational arrangements were correct as of mid-2013. 


\begin{tabular}{|l|l|l|l|l|}
\hline & Worker Co-op & $\begin{array}{l}\text { Multi-Stakeholder } \\
\text { Co-op }\end{array}$ & \multicolumn{2}{l|}{ Consumer Co-op } \\
\hline Democracy & $\begin{array}{l}\text { Members' } \\
\text { meetings 3 } \\
\text { times per year } \\
\text { on contentious/ } \\
\text { budget issues, } \\
\text { but lower level } \\
\text { decision-making } \\
\text { through teams } \\
\text { and fortnightly } \\
\text { meetings with } \\
\text { team reps }\end{array}$ & $\begin{array}{l}\text { Has a board of directors } \\
\text { with 7 members (4 } \\
\text { elected by consumer } \\
\text { members, 2 elected } \\
\text { by worker members, } \\
\text { elected to fill specific } \\
\text { knowledge or sills roles, } \\
\text { and the general man- } \\
\text { ager. Monthly board } \\
\text { meeting held open to } \\
\text { all members }\end{array}$ & $\begin{array}{l}\text { AGM, several } \\
\text { special elections, } \\
\text { meeting minutes } \\
\text { available on the } \\
\text { web }\end{array}$ & $\begin{array}{l}\text { Coordinating } \\
\text { Body (CB) is } \\
\text { group of mem- } \\
\text { ber-directors, } \\
\text { elected at the } \\
\text { AGM, who steer } \\
\text { the overall direc- } \\
\text { tion of the Co-op } \\
\text { between general } \\
\text { meetings. Co-op } \\
\text { has part-time } \\
\text { staff team of 9. }\end{array}$ \\
\hline
\end{tabular}

\section{5: Legal landscapes for co-ops}

Though I have offered some typologies and highlighted some of the arrangements that can exist in cooperatives, it is important to note that these are not exclusive to one country or another. Co-ops are also subject to national and regional rules and understandings; thus, the legal and regulatory state of play differs significantly - for example, between the UK and the US. ${ }^{19}$ The complexity of rules that can apply to a co-op may also be dependent on that business's tax status and how it is legally allowed to - or for various reasons, chooses to - incorporate (Deller et al. 2009, 4-10).

In UK business law, there is no prescribed legal form that a cooperative must take. While this allows for flexibility, it may lead to confusion about the rights and responsibilities of people who want to start a cooperative and what sort of processes to use. Thus, in the UK, a cooperative is an organizational type that can be used with a variety of either incorporated or unincorporated legal forms (Co-operatives UK 2009, 28). As such, Companies House, the UK Registrar of Companies, does not keep a list of registered cooperatives incorporated In the UK. It is possible, however, to inquire whether a specific named organization is incorporated as a cooperative. The organization Co-operatives UK does keep statistical information and is the apex organization of cooperative businesses in the UK. It describes the size of the

\footnotetext{
${ }^{19}$ Though this thesis is not a comparative study of UK and US cooperatives, the greatest amount of detail (and contrasting examples) are given of these two countries in various parts of this thesis. This is due to the authors' language constraints and the original field research plans (detailed in Chapter 3), which focused on Englishspeaking countries.
} 
cooperative economy as having a turnover of 35.6 billion Pounds with over 13.5 million memberships held in cooperative enterprises (Co-operatives UK 2012, 13).

Businesses in the US are regulated on a state-by-state basis, with specific laws of incorporation, fund raising, and financial reporting. Cooperatives are found more abundantly in certain areas of the US than in others, with California, Washington, the upper Midwest/Great Lakes region, and the New England states having high concentrations of cooperative businesses. Much innovation in cooperative law, regulation, and configuration has come from these areas of the country with a strong co-op presence. A full discussion of co-op evolution in the US is chronicled in the work of Zeuli and Cropp (2004). In many cases, however, there are no laws specifically governing cooperative enterprises or accounting for their needs; thus, the legal and regulatory environments can be very uneven with respect to formation of cooperatives. It is important to note that the cooperative environment may also be quite convoluted because of the presence of more than one law governing cooperatives in a state. State laws on co-ops may also apply only to a specific kind of co-op, say an agricultural producer co-op, and not others (Deller et al. 2009, 5). 
Figure 1: Distribution of US cooperatives, minus housing, 2006-2008. ${ }^{20}$

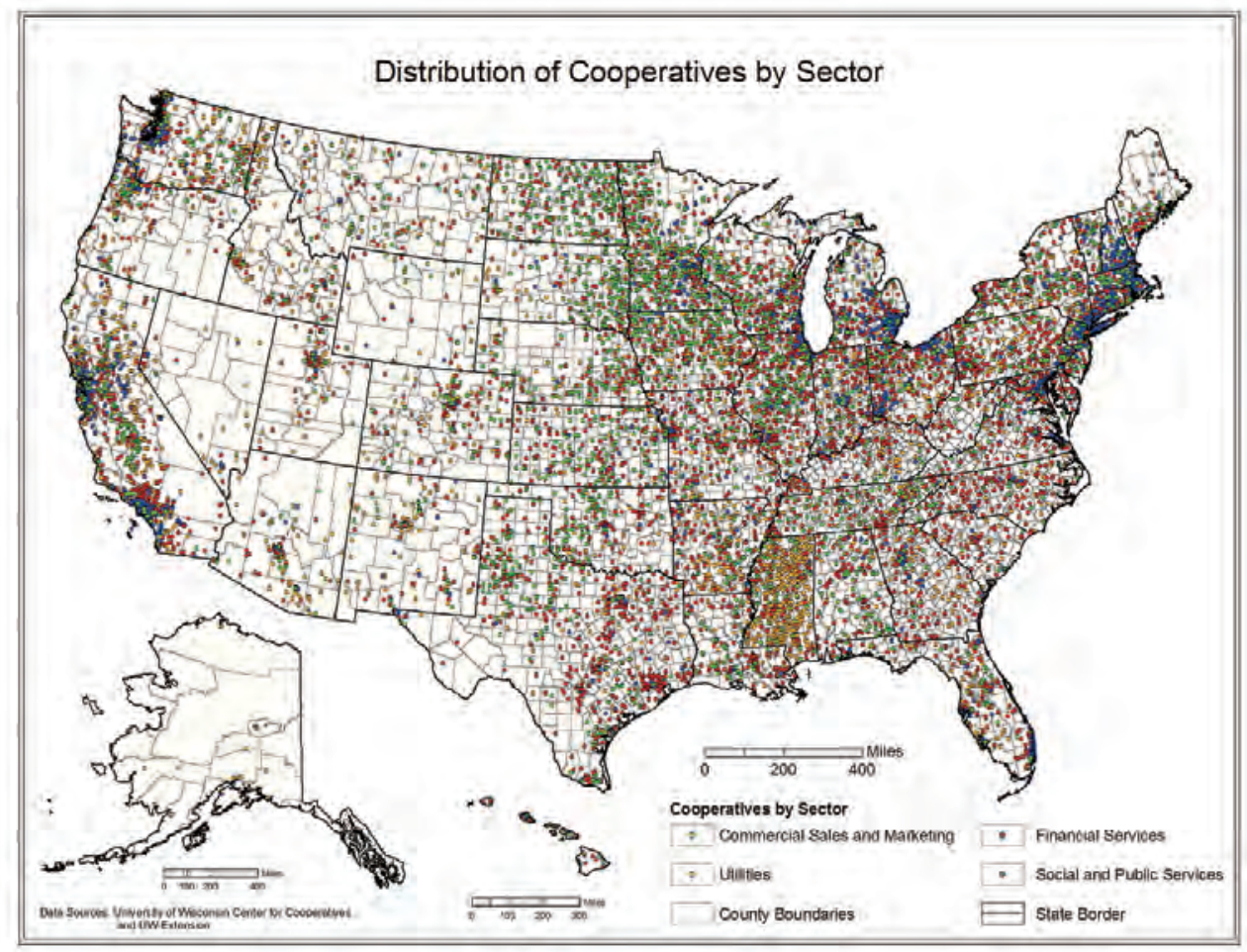

Source: Univ. of Wisconsin Center for Cooperatives

\section{6: Cooperatives and ethical action}

The work of La Montañita Co-op 165 years on from the Rochdale Pioneers, continues to reflect the principles of cooperation that have been handed down in the cooperative movement. In the story of the pomegranate-apple juice project, one is able to see the principle of concern for community coupled with creative strategies to address pressing food system matters. In solving a problem ostensibly caused by bad weather, this juice project illustrates issues of (potential) food waste, food miles and import replacement, power asymmetries between growers and supermarkets, livelihoods of rural communities, producers' access to markets, and short food supply chains. As such, the Co-op is also a manifestation of the work of AFNs and those concerned with systemic change in the food system. However, it was La Montañita's business expertise and organizational capacity as a retailer,

\footnotetext{
${ }^{20}$ This figure is from a report on the Economic Impact of Cooperatives, a USDA grant-funded research program surveying approximately 30,000 cooperatives in all sectors of the US economy, minus the housing sector. Details can be found at http://reic.uwcc.wisc.edu/summary/
} 
its proximity to the supply chain, its willingness to support a local food economy, and its concern for the community that led to them taking action. The Co-op was able to take ameliorative actions to practically address a situation that more diffuse networks of alternative food supporters could only dream of doing. In so doing, they are (re)localizing food ${ }^{21}$ while performing successfully as a business entity.

This raises the question of whether co-ops have a natural competitive advantage over traditional grocery shops or alternative food networks in local food provisioning and how this may appear. One factor is that co-ops - which tend to be smaller and have fewer locations than traditional grocery stores have more flexibility to work with local suppliers - also tend to have smaller operations (Katchova and Woods 2013 , 8). Traditional, centrally-controlled corporate entities must also follow more removed decision making and procurement protocols that occur at larger scales. By contrast, cooperatives frequently have contact with farmers on a personal basis. Cooperatives have cultivated a myriad of business strategies regarding local sourcing that may also be used by traditional grocery shops. Co-ops, however, often see themselves as having some competitive advantage in using these strategies. See Appendix 4 by Katchova and Woods (ibid, 21) for further details.

In many cases, co-ops also have developed deep and historical ties to the farming communities and suppliers that they work with, lending an aura of authenticity to the local food offered through their shops. In this way, co-ops are able to help consumers looking for ways to assess their food, as, they may use local as an indicator of quality, freshness, production processes, or other attributes (Katchova and Woods 2011, 3-4). In a food shopping environment full of options that may feel overwhelming for people who want to make ethical choices about how and what they eat, a cooperative can provide useful choice editing for dealing with complex questions. For some consumers, exploring those questions is tantamount to exploring how their food choices effect their lives, those of others around them, and the planet (Barnett et al. 2005; Jochnowitz 2001; Seyfang 2006).

Cooperatives in their work with local producers can emulate the relations of regard and interactions that are seen in AFNs such as farmers' markets or CSAs, but it is possible that their scale of procurement can lend them further influence in the

\footnotetext{
${ }^{21}$ The concept of (re)localizing food will be more thoroughly discussed in Chapter 2, but it broadly refers to relational understandings (including proximity, quality, authenticity, and connection) between a food product or food system to a territorial or geographic place or a socio-cultural network.
} 


\section{4 | Chapter One}

food system. Additionally, even if co-ops may not have an extensive distribution network as can be seen in La Montañita's juice project, they tend to work with multiple local producers - more than any single alternative food initiative might be able to. Katchova and Woods conducted a study of 10 retail food cooperatives sourcing local food in various areas of the US and found that the co-ops worked with 68 local grower-vendors on average - with one study site working with up to 350 local suppliers $(2013,19)$. In their work with local food producers, cooperatives use a range of strategies to develop and to source local food. An assumption of this thesis is that those strategies are predicated on how cooperatives understand the phenomenon of local food and what meanings and purposes it holds. A further assumption is that a cooperative will base its practices regarding local food on those meanings and how it sees its own possibilities and advantages in that encounter. In the following chapters of this thesis, I offer two case studies that explore the conditions regarding cooperatives' engagement with local food.

\section{7: Posing and addressing the research questions}

Since the 1950s and 70s, cooperatives in food retail in the United States have carved out a niche by offering natural and organic food. As they seek to maintain market share in an era when natural and organic products are much more widely available, some have taken on a further differentiation strategy by offering locally-produced products in their shops. This however, is not a universal approach, and it requires significant investments of time and focused coordination to engage in local provisioning in a meaningful way that benefits coops and local producers. Using two case studies of cooperatives that are engaged in the natural and organic sector and are also interested in local food provisioning through specific, organized initiatives, this research explores why and how retail food cooperatives engage with local food provisioning. This necessitates examining how they understand the issue of local food and their involvement it and what actions they are taking in the name of local food.

Questions to be engaged within the case studies and discussion:

1) How do cooperatives frame local food?

2) What are the practices that retail food cooperatives use to engage in local food? 
3) Do retail food cooperatives have a competitive advantage in local food provisioning? If so, how might that be related to the cooperative identity?

\subsection{1: Theoretical approach}

In trying to understand a cooperative's motivations for becoming involved in local food, I employ the theory of embeddedness. Though it was first presented in economic sociology by Karl Polayni and then Marc Granovetter to characterize the relationship between economy and society (or economic transactions and social actors), embeddedness is a concept widely used in AFN literature. In that context, it indicates individual foods, food systems, or food production techniques as having particular or bounded connections to a territorial or geographic place or to a sociocultural network (Roep and Wiskerke 2010; Sonnino 2007b; Feenstra 2002; Penker 2006). See also section 2.6 of this thesis.

Embeddedness has come to be enacted through attempts at food system (re)localization, which values or prioritizes various aspects of local food provisioning. This local food focus is partly due to the juxtaposition of ideas of global food production systems - which often have negative effects on environmental and social health - with a multitude of ideas of what "local" can mean and what its (positive) attributes are. Thus, as the locality of food becomes a contested characteristic, it is also subject to what Hinrichs (2003) described as "conceptual compression," a perfunctory overlaying of some characteristic onto another concept that is often related. An example of this is the presumption that local food is also organically grown. Recognizing the somewhat unreflexive application of embeddedness in the food literature, I chose to go beyond AFN conceptions of embeddedness, by revisiting its original use by Polanyi. I discussed Polyani's connections between economic and social realms and a call to engage in reform of a "self-regulating" economy that he saw as having dangerous effects on society (Beckert 2007; Block 2001).

Following on from this, I incorporated Gibson-Graham's theory of diverse economies to explicate the process and utility of engaging in a project of reimagining the economy as an ethical space for decision-making and action, rather than as a logical machine over which human action has no influence (Gibson-Graham 2008; GibsonGraham et al. 2013). Diverse economies theorizing creates a space for thinking about what is happening regarding economic action in communities across the world that 
does not conform to neoliberalism. Gibson-Graham discuss this theorizing as an avenue to challenge the "capitalocentric" view of economy, wherein all models of exchange are discussed and characterized relative to capitalism. Gibson-Graham argue that - by choosing to reframe what is happening with respect to five areas (labor [work], enterprise [business], transactions, property, and finance) - scholars and activists can shed light on community-based economies worldwide. In doing this, it becomes possible to see what alternative capitalist and non-capitalist practices are happening - ones that could show ways of engaging in the economy that are regenerative to our planet, as well as to the human and non-human creatures who occupy it.

In light of this thesis's research questions about local food and the process of reframing to understand diverse economies, I examine how cooperatives are framing local food to begin with. I reflect on the urgings of Dewulf et al. (2009) to consider what is being framed when the staff at the co-ops that are my case studies talk about local food. It is through this framing that the co-ops justify and characterize their practices around local food provisioning. This reflects the actor orientation of this research, wherein my informants (social actors in this research) are agents in interpreting and constructing their own realities. Multiple agents also operate in "multiple realities" - suggesting possibly conflicting and diverse configurations of knowledge (Long 2001, 19) - that reflect how those actors conceptualize problems and circumstances they face, as well as the agency they have to address those problems and circumstances (Long 1990; Long and Cruz 2003).

Finally, after examining the case studies' framings and practices regarding local food provisioning gleaned from interviews with the cooperatives' staff, I connect those framings and practices with conceptions of competitive advantage and cooperative identity. I argue that the application of the principles of cooperative identity and the business orientation of cooperatives offer them particular opportunities to engage with local food that are unlike those of either conventional supermarkets or alternative food initiatives.

\subsection{2: Societal and academic contribution}

Cooperatives are part of the social economy, which also includes associations, foundations, mutual societies, social enterprises, and charities - forms of socioeconomic engagement that emerge from the recognition that community values, 
social justice, or other needs are not being catered to by the market (Amin et al. 2002; Hudson 2009). The term social economy is a contested one, and its acceptance varies by country - where different language such as "third sector" or social enterprise may be preferable (Amin et al. 2002; Moulaert and Ailenei 2005; Van Til 1988). For instance, while the "third sector" may indicate something besides the state or the market, the term "social entrepreneurship" may be used more often in the US context for the same idea.) Though many definitions of the social economy exist, there traditionally has been some presumption that economic viability in social economy enterprises comes secondary to social goals: "helping those abandoned by mainstream enterprises or by the welfare state" (Hudson $2009,4)$ or "a safety net or ethical other" needed where both the state and the market had failed (Amin et al. 2002, 2).

Even if providing a return on capital investment may not the primary purpose of organizations in the social economy, they are quite important, as they make up $10 \%$ of European businesses and offer more than 11 million people in Europe paid employment (European Commission 2017). In the US context, cooperatives account for nearly $\$ 654$ billion in revenue and over two million jobs. ${ }^{22}$ As such, cooperatives also occupy an interesting place in the social economy because of their commercial nature. While they do exist to serve their members' needs, those needs may well be of an explicitly commercial nature. And as highlighted by Hudson (2009), the purpose of a social enterprise organization may also be to produce an economic surplus for social uses. Surely, that is the case with many cooperatives: they must be successful and profitable financially in order to execute their social projects and aims. As such, whether the aim is to save a local pub from closure through community ownership or to retain access to essential postal services through a village shop, cooperatives have been held up as potential models to reach social goals in the age of austerity. ${ }^{23}$

\footnotetext{
${ }^{22}$ Figures taken from the summary of the 2009 report Research on the Economic Impact of Cooperatives, a multiphase research project from the University of Wisconsin Center for Cooperatives in the US. http://reic.uwcc. wisc.edu/sites/all/summary-report.pdf

${ }^{23}$ The UK government announced a 2-year, £3.6 million program to assist communities with business development support, funding, and advice to convert local pubs to community ownership. https://www.gov. uk/ government/news/new-36-million-programme-to-help-communities-take-control-of-their-local-pub Other organizations, such as the Plunkett Foundation - a charity that has promoted cooperative community ownership for nearly a century - are also providing assistance to save local businesses. https:// www.plunkett.co.uk/community-shops
} 
There has been a resurgence in the interest in cooperative models, as they might exemplify economic systems that are more resilient in times of crisis. An example is Spain's Basque country, home to the Mondragon Corporation - a group of over 100 small and medium co-operatives in many industries and sectors. Here, the economy has fared significantly better than the rest of Spain, which in 2013 was suffering from a $1.9 \%$ contraction of the economy, a "double-dip" recession, and unemployment at 26\% (Tremlett 2013). ${ }^{24}$ Certainly, while some co-operatives have suffered under the economic recession - including Mondragon's Fagor appliance manufacturing business - others, such as the Organic Valley organic farmers' cooperative based in the state of Wisconsin in the US, are experiencing record growth. ${ }^{25}$ Some consumers are also interested in contracting with co-ops for goods and services, as a more ethical form of consumption, even if they themselves are not members of the co-op. This is evident in the impending delivery of the Coopify online app, which would allow people to find worker-owned co-ops that deliver all sorts of goods and services. ${ }^{26}$

In the academic literature on alternative food networks, cooperatives are an understudied area, except for agricultural producer cooperatives (APCs) (e.g., dairy cooperatives). APCs engage in important issues that AFNs also address (including supermarket power, market access and multi-level governance structures), but APC are more analogous to labor-owned worker cooperatives than to consumer cooperatives - the predominant cooperative form in the retail food sector. While APCs have been the subject of inquiry - particularly in such areas as governance (Novkovic 2008), economic development (Bonin et al. 1993), and fair and preferential trade schemes (Raynolds et al. 2004) - other cooperative sectors (e.g., consumer cooperatives) have been largely missing from the literature. There have been relatively recent contributions from business and economic history studies,

\footnotetext{
${ }^{24}$ According to the European Commission, the Basque region where Mondragon is located continues to outperform national figures on employment. Where Spain's national unemployment rate as $21.2 \%$, the Basque region was at $13.6 \%$ for the same 2015 3rd quarter period. https://ec.europa. eu/eures/main.jsp ?catld=2627\& countryld=ES\&acro=Imi\&lang=en\&regionld=ESO\&nuts2Code=\%20 \&nuts3Code=\&regionName=National\%20Level

${ }^{25}$ Organic Valley reached over 1 billion USD in sales for the first time in its history in December 2015. https:// www.organicvalley.coop/newspress/organic-valley-farmer-owners-convene-co-ops-annual-meeting-celebrate2015-milestones-and-strategize-future-generations/

${ }^{26}$ Coopify is part of the movement toward platform cooperativism, which presents a new approach to share the wealth being creating by the "sharing economy." http://www.yesmagazine.org/people-power/want-to-hire-aworker-owned-co-op-theres-an-app-for-that-20160420
} 
especially in examining cooperatives' relevance for the future (Ekberg 2012; Shaw and Alexander 2008; Webster et al. 2016).

The case studies in this thesis contribute to the overall cooperative literature, the consumer cooperative literature, and the discussion of AFNs working to change food system dynamics. The case studies are related to one another as the field sites are part of a network. They can also stand alone in their approaches to address the specific challenges of their geographical and retailing environments. I showcase cooperatives that are using their dual role as both a buyer and a seller in the natural and organic market with a specific intention to enable the growth of a local food producer community. Notably, I explore these cooperatives' conceptions of local food through staff holding various functions in their organizations, thereby exploring the contradictions and negotiations of local food.

There has been some research into cooperatives' attitudes and actions regarding local food that acknowledges the possibility of diverse views. This is also important to this research, though with different emphases. Hingley (2010) has offered a useful case study of the Lincolnshire Co-operative Society in the UK and their very successful efforts to engage with local food provisioning and networks. That case study - while involving community-based partners and suppliers - captured only the views of the CEO as representing the cooperative. Another study by Hingley et al. (2011) investigating the potential of European co-ops to engage in local food provisioning (both from ideological and practical standpoints) included staff in national and regional executive functions of large cooperatives in Italy and Finland, as well as store manager level staff. The functions of the executive staff are quite removed from the daily operations and interactions around local food provisioning. They also reflect the hierarchical limits that accompany the organizational structures used in the much larger retail food cooperative worlds of Italy and Finland. Finally, Lake and Leviten-Reid's study of small, rural cooperatives in Atlantic Canada (2015) has included both board members and store managers of cooperatives selling conventional (rather than organic) food - though those co-ops also have a much less articulated strategy for promoting local food than the cases I studied. Thus, the cases of this research offer a combination of different size, product focus, use of informants, national context, and scope of their missions than the research otherwise available on these topics. 


\section{8: Thesis structure outline}

This chapter has introduced the thesis, and the remainder of the thesis is organized in the following manner.

\section{Chapter 2: Theoretical framework}

The strategies of local food provisioning used by cooperatives in this research included substantive and frequent interactions with suppliers that result in a high level of embeddedness with the relevant actors. Though the term embeddedness carries many meanings, which will be explored further in this thesis, it is used here to refer generally to the idea that both the overall economy and discrete economic exchanges are situated in a social realm from which they cannot be wholly extracted. This approach is a shorthand combination of theories of embeddedness as discussed separately by two important thinkers from economic sociology: Karl Polanyi and Marc Granovetter. Following on from this, I discuss the implications of embeddedness as a call for social reform and for economic action to be less exploitative of humanity and the earth's resources by utilizing J.K. Gibson-Graham's theory of diverse economies, which reframes the economy as a space for ethical action. The main implication of a socially embedded economy is to allow for a theorization of social conditions, constructions, and networks of relations as being integral to understanding economic exchange that is not accounted for in rational choice theory. Turning then to embeddedness as discussed in AFNs, I offer a critique of ideas regarding (re)localization of the food system.

\section{Chapter 3: Methodology}

The ways in which cooperatives talk about local food reflects their conceptualization or framing of the issue and how they see their role within it. By using an actor orientation that presumes the existence of multiple realities and that agency is possible even for less powerful actors in the globalized food system, I offer a rationale for examining different food cooperatives that have created specific initiatives around local food. This chapter also discusses my use of thick description in reporting the case studies as a hedge against "bleaching human behavior of complexity" (Gibson-Graham 2014, 148) and to aid the transparency of interpretive research. I then discuss my site selection, data generation/collection methods, and my respondents in both cases that appear in the thesis and the initial planning for sites that were finally not included. I close the chapter with some words about my 
analysis process and some post-fieldwork developments that are relevant to the framing of local food in the co-ops studied.

\section{Chapter 4: La Montañita Food Co-op Case Study}

This is the larger of the two case studies in this thesis. It examines a multi-location cooperative based in northern New Mexico that has some interesting features in its comprehensive work regarding local food. I describe the growth and evolution of La Montañita and its framing and then reframing of local food coincident with a strategic plan. This is rounded out by discussion of important post-fieldwork developments at the Co-op and the manifestations of embeddedness and diverse economies to be found there.

\section{Chapter 5: Mountain View Market Co-op Case Study}

Mountain View Market in the southern part of New Mexico is a single-location cooperative that also has a farm operation to supply local farmers' markets, as well as the retail shop location. The area's geographic location and agricultural history present different framings and capabilities around local food provisioning that it has tried to address via the education and support of a community of likeminded local producers. After describing this case, I conclude with a discussion of significant post-fieldwork changes at the Co-op and the manifestations of embeddedness and diverse economies.

\section{Chapter 6: Discussion and Conclusions}

The final chapter presents a discussion of the research questions posed in the thesis, as well as thoughts about the use of embeddedness and diverse economies to understand AFNs and co-ops working on local food. I then offer some thoughts regarding overlaps and disconnections in the literature on AFNs and cooperatives, including some musings on participation and democracy that emerged in my field sites after the fieldwork was concluded. Finally, I close with some reflections on the research process and suggestions for developing further areas of research. 


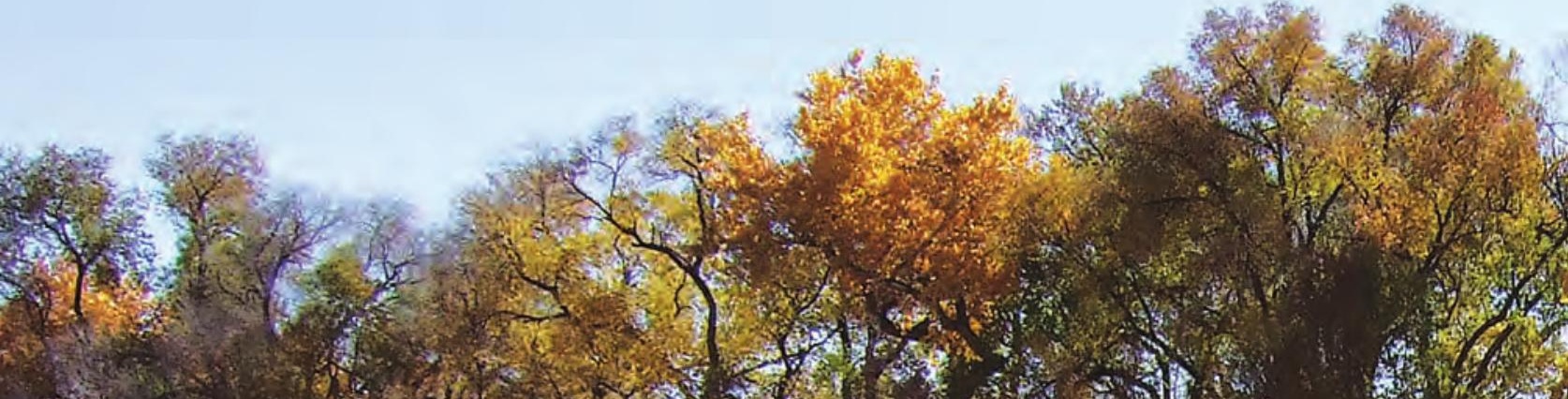

ât:

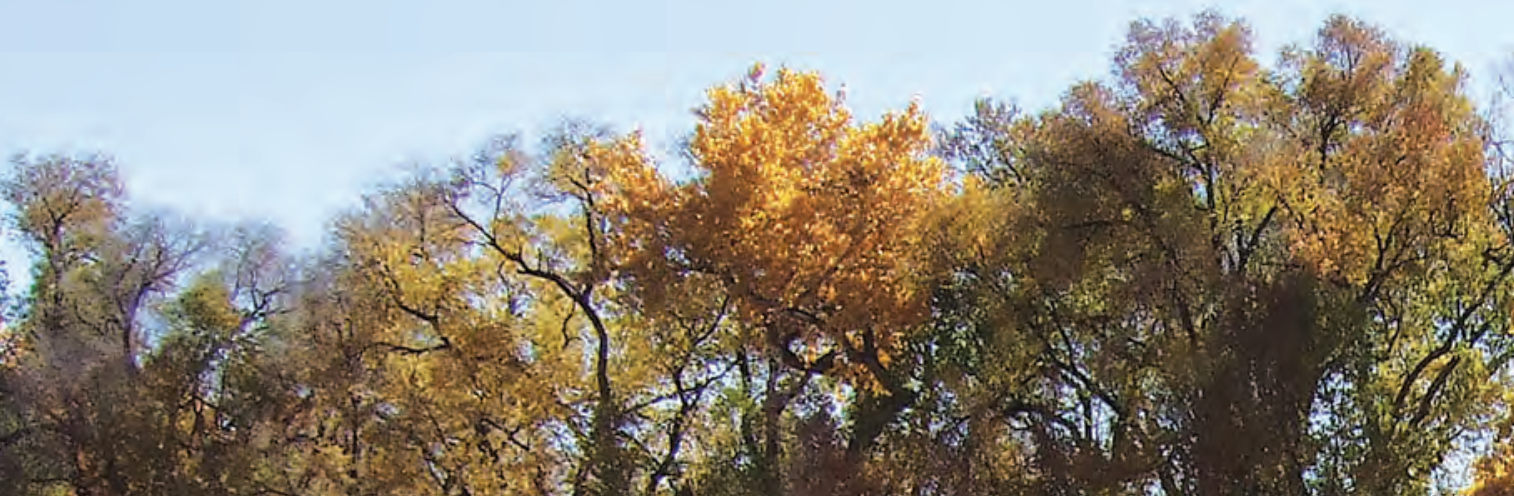

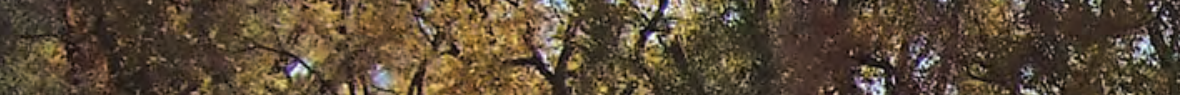
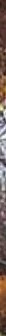

14.

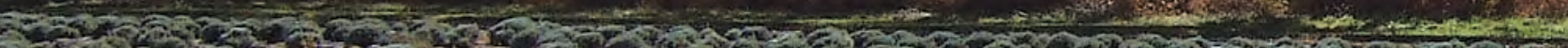

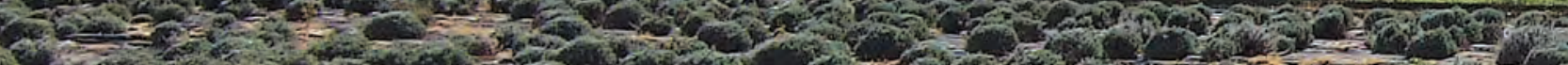
(1)

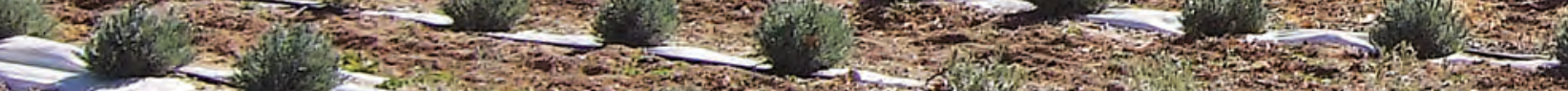

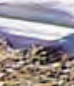

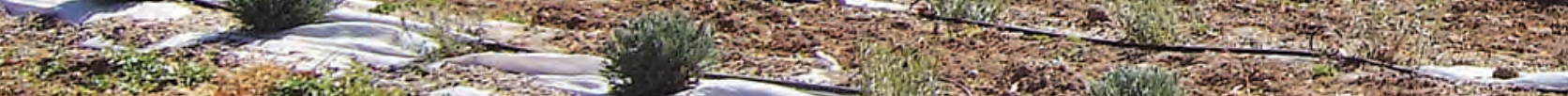

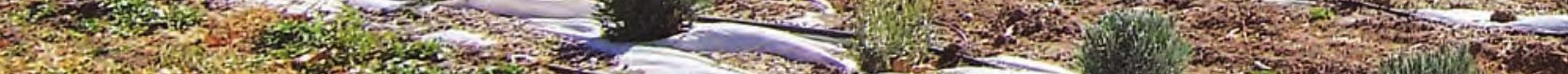

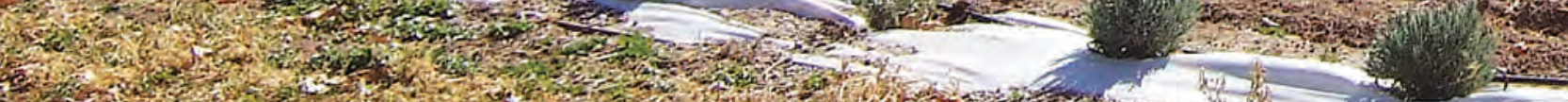

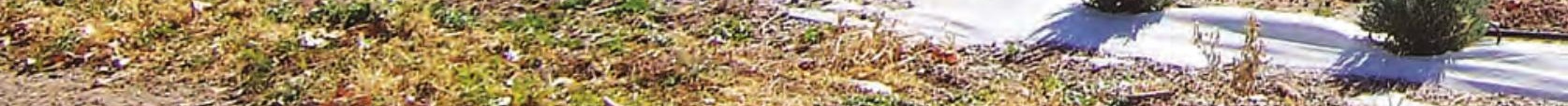

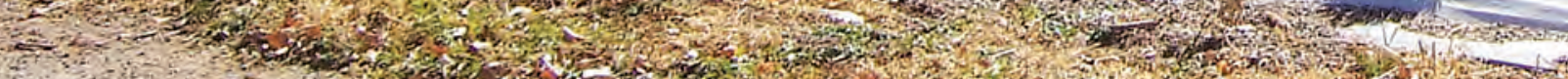

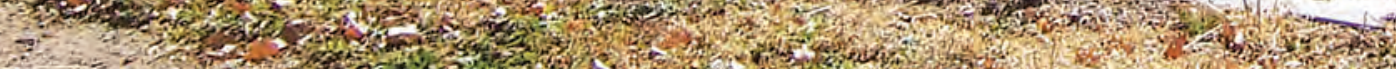

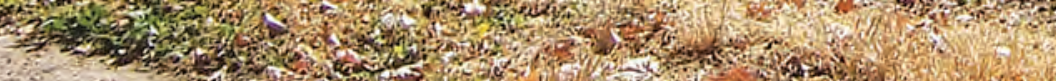

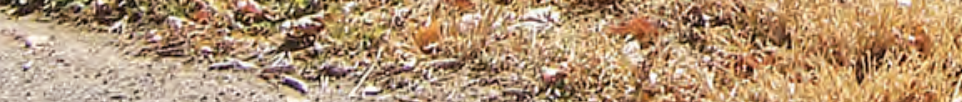

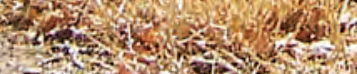

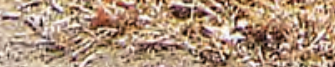



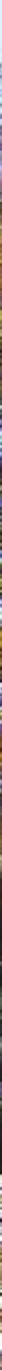

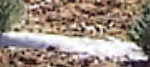

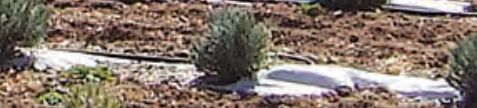

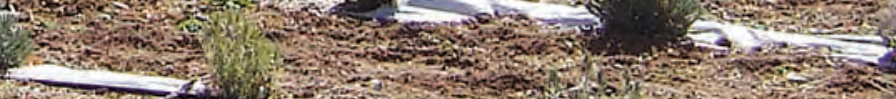

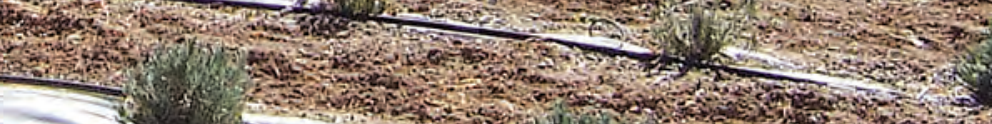

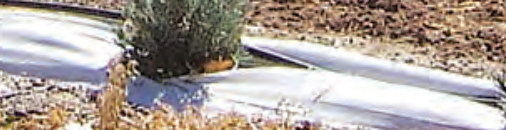

64t:

S.

$-2$

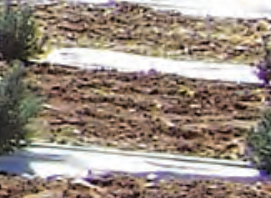

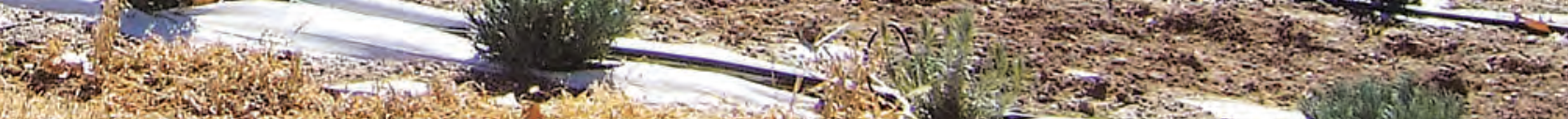

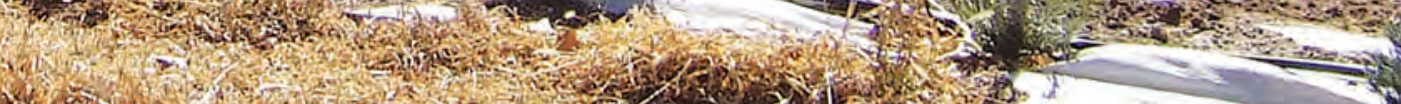

1. 1.

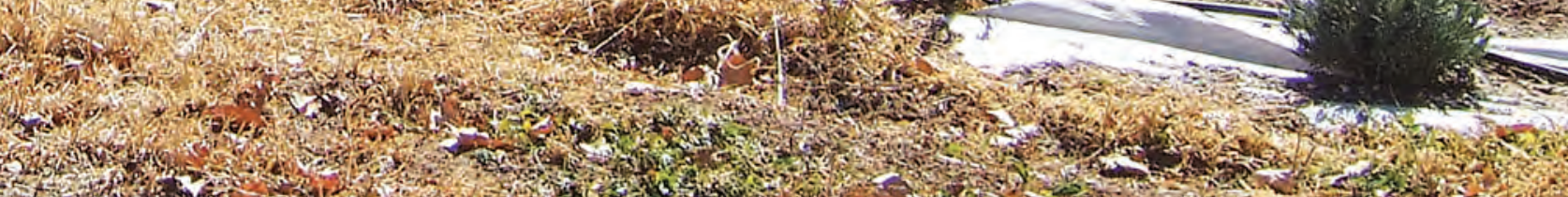

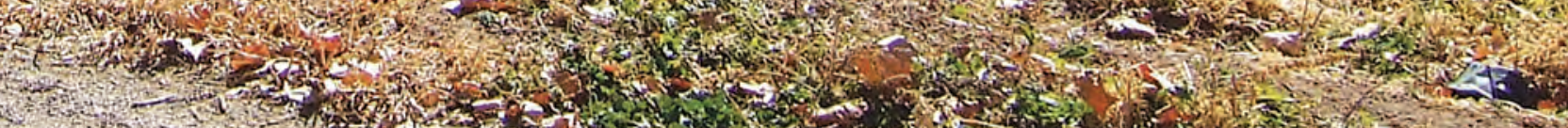
M

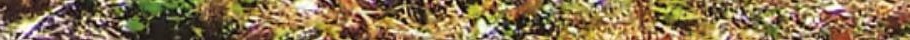


This chapter introduces the theory of embeddedness found in economic sociology and in alternative food literature. It begins with an exploration of the term as used by Karl Polanyi in his 1944 book The Great Transformation and by Marc Granovetter in his 1985 journal article "Economic Action and Social Structure: The Problem of Embeddedness." They form the basis of the theoretical framework. Then it is followed up with J.K. GibsonGraham's theory of diverse economies, which reframes the economy as a space for ethical action. I position local food engagement as a manifestation of embedding processes that seek to reconnect people and ecological processes and with one another, recognizing the possibility of creating an economy that is less destructive of both.

\section{Chapter 2: Theoretical Framework}

Cooperatives focusing on natural and organic foods, including those in this research, are under increasing competition from supermarkets and other players that have entered this sales niche. As such, some co-ops have (re)defined or (re)emphasized their "co-operative difference" that sets them apart from conventional food retailers that might price their products more competitively. By creating product branding, community initiatives, and farmer support mechanisms firmly rooted in a statement cooperative of identity, many co-ops have been able to survive and thrive. Such positioning may be no less market-oriented than the actions taken by conventional retailers, as the premise of market-orientation is complex and cannot be strictly defined or governed by price. Purchasing decisions, trade (with or without currency), and commercial interactions are grounded in a social realm, not just an economic one.

The term embeddedness, as found in economic sociology, has been used to describe this relationship between the social and the economic, and it forms the basis of the theoretical framework of this research. This chapter will discuss briefly the development of the idea of embeddedness and its use in economic sociology, as well as its use by scholars of food movements and networks. This section further incorporates a conceptualization of embeddedness as what can result by uncovering diverse economic practices happening in communities - as described by economic geographers J.K. Gibson-Graham. ${ }^{27}$ These practices that contribute to diverse economies show the possibilities for agency and building systems of

\footnotetext{
${ }^{27}$ J.K. Gibson-Graham is the collaborative academic pen name of Dr. Katherine Gibson and the late Dr. Julie Graham. While Dr. Graham died in 2010, several references published subsequent to her death under that collaborative name were used in this work and appear as such.
} 
exchange undergirded by motivations beyond profit. Such agency reflects the ethical priorities of the cooperative movement and the field sites of this research.

\section{1: Embeddedness by Polanyi}

As a sociological concept, embeddedness originated in the field of economic sociology, an academic subfield of sociology 'which explicitly addresses the context, process, and outcomes of exchange' (Hinrichs 2000, 296). Sociologists Niel Smelser and Richard Swedberg describe classic economic sociology in The Handbook of Economic Sociology (2005) as arising between 1890-1920 - mainly with the work of Durkheim and Weber, but with earlier literature from Montesquieu and de Tocqueville prefiguring some important concepts (ibid, 7). Smelser and Swedberg identify a second major period of development of a new economic sociology (from the early 1980s to the present) that was coincident with the ascendancy of neoliberalism on the world stage, as personified by Thatcherite and Reaganite politics. They argue that this neoliberalism brought to the fore questions of economy, as well as the economists who engaged with those questions. Those economists redrew "the traditional boundary separating economics and sociology, and [made] forays into areas that sociologists by tradition saw as their own territory. ... Likewise, sociologists began to reciprocate by taking on economic topics" (ibid, 14).

It was in 1944, between the two periods of development of economic sociology, that the concept of embeddedness was originated by Karl Polanyi to characterize the relationship between the economy and society or social actors (Block 2001). Though embeddedness has been expounded on significantly since the early 1980s, most notably by Granovetter (1985), Smelser and Swedberg take pains to point out that Polanyi used the term in a very different way than modern economic sociologists do. This is despite it being the building block of its current usage $(2005,13)$. Whereas, Smelser and Swedberg say, the modern use describes economic action as being situated in forms of social structure(s), Polanyi's use described economic action as being destructive when "not governed by social or noneconomic authorities" $(2005,13)$. There is an emphasis here on society having a specific influencing and managing function in the latter definition. While neoclassical economic theory presumes and advocates for independent and autonomous markets that are selfregulated (Peck 2005) and economic actors that are unconnected (Smelser and Swedberg 2005, 4), embeddedness à la Polanyi indeed presumes instead that economy is "subordinated to politics, religion, and social relations" (Block 2001, 
xxiv). Thus, the embeddedness Polanyi described applied not only pre-modern (pre-Industrial) societies, but eventually extends to all economies, because of their inextricability from their societies.

Polanyi originated and elaborated the term embeddedness in The Great Transformation, first published in 1944. The Great Transformation explores how the First World War was followed by the Great Depression and worldwide economic collapse, yet the War was actually preceded by a century of peace and prosperity (1815-1914) in Europe (Block 2001, xxii). Polanyi attributes these post-1914 economic calamities to the rise of free-market liberal capitalism and its attendant destabilizing effects on society. It is notable that Polanyi was writing about the economic system of the end of 1800s, which had evolved from the first Industrial Revolution, with its resultant squalid factory conditions and rapid urbanization that wreaked havoc on the British working class. Changes in social systems, such as the restructuring and abolition of mechanisms for poverty relief (the Elizabethan Poor Law), and the decline of cottage industries (Birchall 1997, 1-6; Thompson 2012, 27-32) pushed landless agriculturists from the countryside into grueling and exploitative factory and mill life (Block 1990, 40; Birchall 1994).

Polanyi, who studied and wrote about economics, politics, and anthropology, characterized the social upheaval of the time as an effect of the dismantling of institutional structures that ushered in self-regulating markets.

"Not economic exploitation, as often assumed, but the disintegration of the cultural environment of the victim is then the cause of the degradation. The economic process may, naturally, supply the vehicle of the destruction, and almost invariably economic inferiority will make the weaker yield, but the immediate cause of his undoing is not for that reason economic; it lies in the lethal injury to the institutions in which his social existence is embodied" (Polanyi 2001, 164).

This was a direct challenge to contemporary economists' theorization that deregulation completely commodified land, labor, and capital, thus allowing a free economy to have massive economic growth from advances in efficiency (Block 1990, 40, emphasis mine). Indeed, Polanyi described land, labor and capital as fictitious commodities, because they do not exist, per se, for the purpose of market exchange. 


\begin{abstract}
"Labor is only another name for a human activity which goes with life itself, which in its turn is not produced for sale but for entirely different reasons, nor can that activity be detached from the rest of life, be stored or mobilized; land is only another name for nature, which is not produced by man; actual money, finally, is merely a token of purchasing power which, as a rule, is not produced at all, but comes into being through the mechanism of banking or state finance" (Polanyi 2001, 75).
\end{abstract}

Polanyi insisted that the growth of an economy of industrial capitalism was due to a reconfiguration of the changes in society, as well as market and political changes.

The changes in society brought by this situation were not without some challenge, however. Polanyi described a "double movement" between society and capitalism in which, after a period of expansion of capital markets, there would come protective counter-movements (e.g., in the form social movements, worker protection laws, or regulation of markets by society) (Polanyi 2001, 136). In this way, The Great Transformation, also discusses the decline of laissez-faire capitalism following the first Industrial Revolution in Britain. These counter-movements were a societal response that swung the pendulum away from the destabilizing forces of capital accumulation that led to the exploitation of resources and to detrimental effects on human and environmental health (Holt-Giménez and Shattuck 2011, 113). The manifestations of this double movement helped humankind "to resist the pernicious effects of a market-controlled economy" (Polanyi 2001, 80).

While some of those counter-movements lead to government reforms and regulations of industry, there also came initiatives from individuals, small groups, and civil society to remediate problems. The cooperative movement was one manifestation of this. Indeed, Robert Owen, the Welsh cotton miller and social reformer considered as a founder of the cooperative movement, was particularly singled out by Polanyi in The Great Transformation. Polanyi devoted significant discussion to Owen's initiatives at New Lanark Mill and his writings on the inevitability of an unregulated market economy to have negative effects (Polanyi 2001, 89, 133-136, 268).

Polanyi saw a threat in free market capitalism, saying that its proponents would prefer that society would be run "as an adjunct to the market. Instead of the economy being embedded in social relations, social relations [would be] embedded 
in the economic system" (Polanyi 2001, 60). Though such attempts to move toward that end would have negative effects, Polanyi surmised that a fully disembedded economy could not exist for long, despite capitalism's best attempts: "Such an institution could not exist for any length of time without annihilating the human and natural substance of society; it would have physically destroyed man and transformed his surroundings into a wilderness" (ibid, 3 ).

\section{2: Embeddedness beyond Polanyi}

Embeddedness as a concept underwent a major shift and an injection of interest in 1985. This was due to an important publication by economic sociologist Marc Granovetter, who posited that economic action is explained by and constrained within cultural and institutional contexts and networks of ongoing relationships. Granovetter's often-cited work, "Economic Action and Social Structure: The Problem of Embeddedness" (1985), ushered in the term "new economic sociology" (Smelser and Swedberg 2005, 14), and its influence on this research field cannot be overstated. It engendered the most influential discussions of the discipline and became its "central organizing principle" Krippner and Alvarez (2007, 220). In his article, Granovetter examined "the extent to which economic action is embedded in structures of social relations" $(1985,481)$ and addressed how both sociologists and economists were characterizing motivations for participation in economic transactions.

In his article, Granovetter hypothesized that both sociologists and economists were wrong in their estimation of the extent to which economic action was informed by social contexts, both in the past and the current day. Granovetter critiques as "oversocialized" the view that premarket and pre-Industrial societies incorporated the rules and expectations of society and kinship more significantly in economic exchange than do modern economies. Similarly, he critiques as "undersocialized" the view that economic action in societies - even tribal ones - are more correctly explained by rational, individual, self-interested motives: "I assert that the level of embeddedness of economic behavior is lower in nonmarket societies than is claimed by substantivists and development theorists, and it has changed less with "modernization" than they believe; but I argue also that this level has always been and continues to be more substantial than is allowed for by formalists and economists" (ibid, 482-483). 
Granovetter's embeddedness has not gone without critique. It has been described as vague by Smelser and Swedberg $(2005,15)$ : "His own definition of embeddedness is quite general and states that economic actions are 'embedded in concrete, ongoing systems of social relations' (Granovetter 1985a, 487)." Uzzi (1996) has critiqued embeddedness as a concept because it does not explain how social factors influence outcomes. Krippner (2001) also takes issue with Granovetter's conceptualization of economic activity and the level of abstraction employed by network analysis to be used with Granovetter's embeddedness. In an academic symposium on embeddedness, Granovetter himself somewhat disavowed the concept as now almost meaningless (Krippner et al. 2004, 113), due to the proliferation of the term through various modes of social science - including gender studies, development, political science, etc. - with no consensus with respect to its meaning (Krippner and Alvarez 2007, 220). The diverse mix of scholars interested in embeddedness may indicate, however, that there is widespread rejection of neoliberalism's notions of rational choice to explain economic interactions. As rational choice theory depends on a belief that individuals act in consistent, self-interested, and rational ways to maximize their own utility (happiness) (Hill and Myatt 2010, 1), embeddedness's consideration of social relations rejects the atomized individualism of rational choice.

There have been many attempts to expand on the concept of embeddedness and clarify how it might be explained in different contexts. According to Beckert $(2007,10)$ the staying power of the embeddedness concept - despite all its various readings - can partially be attributed to the multiplicity of applications to various sociological subfields. Beckert particularly sites Zukin and Dimaggio's exposition (1990) of four types of embeddedness (cognitive, cultural, [socio]structural, and political) as bringing embeddedness closer to the meanings that can be gleaned from The Great Transformation. Other interpretations of embeddedness include

- discussion of three different types of social embeddedness to aid exchange (temporal, network, and institutional) by Rooks et al. (2000);

- Jessop's description of embeddedness (2001) as happening on three different levels of interaction (interpersonal, institutional, and societal);

- $\quad$ and Uzzi's discussion of the use and limitations embeddedness in networks of firms (1996). 
One issue that Hess (2004) emphasizes in giving more clarity to the definition of embeddedness is to consider "who is embedded in what" - with "who" defining the actors involved and "what" defining the social and cultural structures involved - as well as which geographical scales are at play. Hess asserts that Polanyi's embeddedness was concerned with the different types of economy (who) embedded in society (what), while Granovetter's embeddedness was concerned with individuals participating in moments of economic exchange (who) and networks of interpersonal relationships (what) (ibid, 2004, 169-171). The table from Hess below describes a variety of perspectives on embeddedness from different academic areas.

Table 3: Who is embedded in what? Different views on embeddedness

\begin{tabular}{|c|c|c|c|}
\hline & Who? & In what? & Geographical Scale \\
\hline $\begin{array}{l}\text { Polanyi's The Great } \\
\text { Transformation }\end{array}$ & $\begin{array}{c}\text { "The economy," } \\
\text { systems of } \\
\text { exchange }\end{array}$ & $\begin{array}{c}\text { "Society," social and cultural } \\
\text { structures }\end{array}$ & $\begin{array}{l}\text { No particular scale, } \\
\text { but emphasis on the } \\
\text { nation state }\end{array}$ \\
\hline $\begin{array}{l}\text { Business systems } \\
\text { approach }\end{array}$ & Firms & $\begin{array}{l}\text { Institutional and regulatory } \\
\text { frameworks }\end{array}$ & $\begin{array}{c}\text { Nation state, "home } \\
\text { territory" }\end{array}$ \\
\hline $\begin{array}{l}\text { New economic } \\
\text { sociology }\end{array}$ & $\begin{array}{c}\text { Economic } \\
\text { behavior, } \\
\text { individuals and } \\
\text { firms }\end{array}$ & $\begin{array}{l}\text { Networks of ongoing social } \\
\text { (interpersonal relations) }\end{array}$ & No particular scale \\
\hline $\begin{array}{l}\text { Organization and } \\
\text { business studies }\end{array}$ & Firms, networks & $\begin{array}{c}\text { Time, space, social structures, } \\
\text { markets, technological } \\
\text { systems, political systems ... }\end{array}$ & No particular scale \\
\hline Economic geography & Firms & $\begin{array}{c}\text { Networks and institutional } \\
\text { settings }\end{array}$ & Local/regional \\
\hline
\end{tabular}

(Hess, 2004, 173, adapted)

With respect to scale, Hess expresses a particular concern with using a spatial understanding of embeddedness in economic geography to privilege local and regional networks and clusters as pathways for economic development in a globalizing world (2004, 174-176). He discusses this idea of "new regionalism" or "new localism" as being problematic in its tendency to overvalue and undertheorize the importance of proximity and scale in describing regional economic development and nourishing trust relations. In this, he takes issue with the idea that local "institutional thickness" necessarily reinforces embeddedness of local enterprises. Institutional thickness was most influentially described by Amin and Thrift (1995) to 
posit that the very presence of a large number of local institutions - with high levels of interaction and mutually understood ideas of a common local project - promotes economic growth and offers multiple routes to development.

While not refuting territorial or local forms of embeddedness, Hess (2004) cites global production networks and transnational ethnic networks as examples of local and translocal relations that contribute to regional development. In particular, he offers studies of Taiwanese business networks in Silicon Valley, California (Hsu and Saxenian 2000; Saxenian 1999). Fostering the links between Taiwanese business groups in Taiwan and in Silicon Valley is, to Hess, part of a process of globalization. Yet he rejects a disembedded version of globalization, saying that it is "obviously not a process of disembedding based on mere market transactions and impersonal trust, but rather a process of transnational (and thereby translocal) network building or embedding, creating and maintaining personal relations of trust at various, interrelated geographical scales" (Hess 2004, 176).

Regardless of the vagaries of its use, embeddedness has served an important function in economic sociology: to help orient economic sociology as a discipline. While Smelser and Swedberg have highlighted possible areas of confluence and deepening understanding across the boundaries of economics and sociology - what they termed "complementary articulation" $(2005,20)$ - the concept of embeddedness in economic sociology, in fact, has served to act as a foil and a critique of the Homo economicus model of neoclassical economics, thus helping to define economic sociology against economics as a field of study (Krippner and Alvarez 2007; Sonnino 2007a).

\section{3: Embeddedness on two continua}

Returning to the idea that Granovetter's discussion of embeddedness as a way to understand the motivations of participating in economic exchanges, it can be supplemented with an understanding of economic marketness and instrumentalism. Block (1990) described a continuum of "marketness" in economic theory. A high degree of marketness signifies how much price itself dominated considerations of participating in transactions. The higher the marketness, the more pricing is important. The lower the marketness, the more non-price considerations drive decisions. "It is not as though prices are irrelevant under conditions of low marketness, it is just that they compete with other variables, so that one would 
expect price differences to be much larger before they led actors to respond" (ibid, 51).

The second continuum posited by Block to describe motives for participating in transactions is the concept of instrumentalism of the individual. People make decisions out of their own self-interest. But to what degree? Block describes a continuum to understand "the degree to which self-interest places economic goals ahead of friendship, family ties, spiritual considerations, or morality" $(1990,54)$. While one's strictly individual economic gain is at one end of the instrumentalism spectrum, other values (like the welfare of others) can be seen at lower levels of instrumentalism. For example, a firm may choose to purchase goods from a pricier supplier because of social relations that need to be cultivated or preserved (immediately or in the future), signaling a high degree of social embeddedness. This is not to say that high embeddedness necessarily means a low degree of economic self-interest. It is likely that cultivating social embeddedness through relationships and community membership contributes to economic viability - both at the point of sale and outside of price-defined transactions, such as is seen in building rapport between farmers and their customers at a market or CSA business (Thornburg and Ramsey 2013).

Importantly, embeddedness also offers conceptualization of activities that fit within both an economic and non-economic framework - for example, the cultivation of social relationships outside of a moment of commercial exchange. Recognizing economic and non-economic activities as contributing to embeddedness also allows a co-existence between a multitude of capital forms and society (Block 2001). Thus, even modern economies can exhibit very socialized business practices. This is an orientation that is particularly used by co-ops, as they can straddle various capitalist (and non-capitalist) forms simultaneously. Indeed, the field sites for this research exhibited a range of economic strategies that showed different degrees of marketness and instrumentalism, especially with respect to local food provisioning.

While co-ops must operate in capitalist environments, their orientation goes beyond the neoliberal framework of profit maximization and return on investment to shareholders. In deciding on business strategies, co-ops must take into account the wishes of their member-owners and their cooperative principles, which may run counter to the purest expressions of market exchange. This might include paying 
higher-than-market wages to employees or prices to suppliers, privileging a vendor from certain demographic groups, or engaging in volunteer and donation-bases of exchange. Before moving on to the relevance of embeddedness for food systems, I will discuss the efforts of J.K. Gibson-Graham to unravel complexity in (and reveal insights about) how economic transactions are framed. This framing shows both the dominance of a structuralist view of market capitalism and the potential to challenge that view through actor-oriented approaches. This will have relevance to alternative food networks that use concepts of food system embeddedness.

\section{4: Changing the frame - from a capitalist economy to diverse economies}

The work of J.K. Gibson-Graham and their explorations of post-capitalism may be particularly useful in understanding the intricacies of economic life that embeddedness would appear to encompass. Gibson-Graham warned against the reification of a conception of economy that is separate from social processes. Rather, economy must be seen as "organizing the practices and processes that surround it, while at the same time being formatted and maintained by them" (2006a, xxxiv). In this way, capitalism is a performed phenomenon - with academics theorizing its description, role, and influence in human society as partly constituting its position of power. "When we look back on our previous lives as radical geographers, we recognize our role as critical academics in inventing and consolidating a certain sort of capitalism by endowing it with encompassing power, generalizing its dynamics and organizations, and enlarging the spaces of its agency" (Gibson-Graham 2008, 25).

Gibson-Graham posits that failure to recognize this contribution to the dominance of capitalism in academic discussion engenders what they call a "capitalocentric" vision, meaning that all manifestations of economic life are described with respect to neo-liberal capital processes: "fundamentally the same as (or modeled [sic] upon) capitalism, or as being deficient or substandard imitations; as being opposite to capitalism; as being the complement of capitalism; as existing in capitalism's space or orbit" $(2006 a, 6)$. The result of this would have the performative effect of both limiting the view of how the economy is organized, and of how it can be organized.

The framing of diverse economies (see Table 4) also allows coexistence of noncapitalist and alternative practices, along with capitalist practices. Gibson-Graham see a necessity in an ontological reframing of economic life, not as a performative 
act in itself, but as part of the groundwork to build community economies (2008, 18). This framing helps mitigate the effects of "capitalocentrism" and allows a different political project - one built on the engagement of the economy beyond the profit-making, atomized, instrumental action of neo-liberal thinking. This reframing is a method that allows people to understand their different roles as economic actors and is part of a concerted strategy to shift the understanding of what makes up an economy (Gibson-Graham et al. 2013). In this process of reframing, Gibson-Graham emphasizes the necessary action and "continual work of making and remaking" space for a different economic reality in the face of the dominant discourse of capitalism (2006b, xxvii).

Table 4: The Diverse Economy ${ }^{28}$

\begin{tabular}{|c|c|c|c|c|}
\hline LABOR & ENTERPRISE & TRANSACTIONS & PROPERTY & FINANCE \\
\hline WAGE & CAPITALIST & MARKET & PRIVATE & $\begin{array}{c}\text { MAINSTREAM } \\
\text { MARKET }\end{array}$ \\
\hline $\begin{array}{c}\text { ALTERNATIVE } \\
\text { PAID }\end{array}$ & $\begin{array}{c}\text { ALTERNATIVE } \\
\text { CAPITALIST }\end{array}$ & $\begin{array}{c}\text { ALTERNATIVE } \\
\text { MARKET }\end{array}$ & $\begin{array}{c}\text { ALTERNATIVE } \\
\text { PRIVATE }\end{array}$ & $\begin{array}{c}\text { ALTERNATIVE } \\
\text { MARKET }\end{array}$ \\
\hline UNPAID & NON-CAPITALIST & NON-MARKET & OPEN ACCESS & NON-MARKET \\
\hline
\end{tabular}

(Gibson-Graham et al. 2013, 13)

A research project emerged from the work of Gibson-Graham and has evolved into an international network of activists and scholars interested in making visible and exploring a variety of diverse economic practices. ${ }^{29}$ Gibson-Graham et al. (2013) use a schema shown above to explain an economy that is broader than one that limits itself to specific incarnations of labor (paid wage), enterprise (capitalist), transactions (market), property (private), and finance (mainstream market). Examples of each the heading categories are offered in the following Tables 5-9. In each, a recognized dominant neoliberal incarnation is listed in the left-most block, with increasingly non-capitalist forms (and examples of such immediately below) in the middle and right-most blocks.

\footnotetext{
${ }^{28}$ There have been previous incarnations of this chart, offering just three columns denoting labor, enterprise, and transactions. See Gibson-Graham and Roelvink, 2009 and Cameron and Gibson, 2001.

${ }^{29}$ Further information is available at http://www.communityeconomies.org/Home and also at http:// takebackeconomy.net/.
} 
Table 5: Diverse Labor Identifier

\begin{tabular}{|c|l|l|}
\hline \multirow{2}{*}{ PAID LABOR } & \multicolumn{1}{|c|}{ ALTERNATIVE PAID LABOR } & \multicolumn{1}{|c|}{ UNPAID LABOR } \\
\cline { 2 - 3 } & $\begin{array}{l}\text { Self-employed } \\
\text { Cooperative } \\
\text { Indentured } \\
\text { Reciprocal labor } \\
\text { In-kind } \\
\text { Work for welfare }\end{array}$ & $\begin{array}{l}\text { Housework } \\
\text { Family care } \\
\text { Neighborhood work } \\
\text { Volunteering } \\
\end{array}$ \\
\hline
\end{tabular}

(Gibson-Graham et al. 2013, 38)

Table 6: Diverse Enterprise Identifier

\begin{tabular}{|c|l|l|}
\hline \multirow{2}{*}{ CAPITALIST } & ALTERNATIVE CAPITALIST & \multicolumn{1}{c|}{ NON-CAPITALIST } \\
\cline { 2 - 3 } & $\begin{array}{l}\text { Green capitalist firm } \\
\text { Socially responsible firm } \\
\text { State-run enterprise }\end{array}$ & $\begin{array}{l}\text { Cooperative } \\
\text { Social enterprise } \\
\text { Self-employed business } \\
\text { Slave enterprise } \\
\text { Feudal estate }\end{array}$ \\
\hline
\end{tabular}

(Gibson-Graham et al. 2013, 72)

Although Gibson-Graham et al. lists cooperatives as non-capitalist in the schematic above, I contend that cooperatives can exhibit a multiplicity of economic behaviors and must operate as revenue-generating enterprises in order to be sustainable. They typically operate in capitalist arenas and have revenue goals, despite having specific goals beyond their bottom line and return on investment. As emphasized by a January 2001 report offering a 60-point action plan to help revitalize the UK cooperative sector, "The Co-operative Movement cannot be sustained simply on the basis of its social commitment" (The Co-operative Commission 2001, 12). Whether they reinvest those revenues into their businesses or distribute them to their communities, they can still function in a manner that fulfills the cooperative ethos and laws applicable to co-ops in their operational contexts (Deller et al. 2009; Zeuli and Cropp 2004). See also sections 1.2-1.5 of this thesis. 
Table 7: Diverse Property Identifier

\begin{tabular}{|l|l|l|}
\hline \multicolumn{1}{|c|}{ ALTERNATIVE PRIVATE } & \multicolumn{1}{|c|}{ NON-CAPITALIST } \\
\cline { 2 - 3 } & $\begin{array}{l}\text { State-owned } \\
\text { Penanted } \\
\text { Pinety-nine-year lease } \\
\text { Customary } \\
\text { Community-managed } \\
\text { Community trust }\end{array}$ & $\begin{array}{l}\text { Atmosphere } \\
\text { Water } \\
\text { Open ocean } \\
\text { Ecosystem services }\end{array}$ \\
\hline
\end{tabular}

(Gibson-Graham et al. 2013, 147)

Table 8: Diverse Transaction Identifier

\begin{tabular}{|c|l|l|}
\hline \multicolumn{1}{|c|}{ ALTERNATIVE MARKET } & \multicolumn{1}{|c|}{ NON-MARKET } \\
\cline { 2 - 3 } MARKET & $\begin{array}{l}\text { Fair trade and direct trade } \\
\text { Reciprocal exchange } \\
\text { Alternative currency } \\
\text { Local trading system } \\
\text { Community-supported agriculture } \\
\text { Barter } \\
\text { Underground market } \\
\text { Informal market }\end{array}$ & $\begin{array}{l}\text { Household flows } \\
\text { Gift giving } \\
\text { Gleaning } \\
\text { State allocations } \\
\text { Hunting, fishing, gathering } \\
\text { Theft, poaching }\end{array}$ \\
\hline
\end{tabular}

(Gibson-Graham et al. 2013, 111)

Table 9: Diverse Finance Identifier

\begin{tabular}{|c|c|c|}
\hline & ALTERNATIVE MARKET FINANCE & NON-MARKET FINANCE \\
\hline $\begin{array}{c}\text { MAINSTREAM } \\
\text { MARKET FINANCE }\end{array}$ & $\begin{array}{l}\text { State banks } \\
\text { Government-sponsored lenders } \\
\text { Credit unions } \\
\text { Microfinance } \\
\text { Friendly societies } \\
\text { Community-based financial institutions }\end{array}$ & $\begin{array}{l}\text { Sweat equity } \\
\text { Community-supported business } \\
\text { Rotating credit funds } \\
\text { Family lending } \\
\text { Donations } \\
\text { Interest-free loans }\end{array}$ \\
\hline
\end{tabular}

(Gibson-Graham et al. 2013, 177)

Another danger of the perspective of having one recognized economy is that it reifies an understanding of economy that positions modern societies against pre-modern societies. This prizes exchanges that exhibit higher degrees of rational choice as further along developmentally than those that incorporate social networks more obviously (Beckert 2007). In this respect, there is a further link to Polanyi, whose double movement idea refuted the presumption of a linear path of development 
for the economic organization of societies. "Embeddedness is not a characteristic that separates pre-modern economies from modern ones. Based on the notion of a "double movement," social change is conceptualized as a dynamic process of oscillation between embedding, disembedding and reembedding" (ibid, 19). In this way, it may be more useful to speak of embedding as a process rather than embeddedness as a quality.

\section{5: "Doing" embeddedness}

Though many scholars have expanded on Polanyi's embeddedness, Beckert notes that there is a significant divergence between what Polanyi's discussion offers and the ways in which subsequent scholars have chosen to explore it. "In The Great Transformation Polanyi did not aim to understand the functioning of market exchange in order to explain the social preconditions for market efficiency; he was concerned with what happens to social order and political freedom when economic exchange is organized chiefly through self-regulating markets" (Beckert 2007, 17). Beckert assesses that economic sociology has neglected to examine vital questions about embeddedness in favor of discussing embeddedness as an expression of economy within social life (or vice-versa). While Beckert acknowledges that economic sociology has not widely accepted The Great Transformation as social theory exhorting a call to arms, he claims that Polanyi's text reflects a concern about the deleterious effects of self-regulating markets that justifies an engagement with social reform (ibid, 17). It is Beckert's proposition of engaging with vital questions of embeddedness and economy that I find most useful for this research.

If there is some social reform mission to be considered in examining embeddedness, how could it be done and to what end? One could consider fostering interconnectedness and curtailing exploitation of society as a component: "The true criticism of market society is not that it was based on economics-in a sense, every and any society must be based on it - but that its economy was based on self-interest" (Polanyi 2001, 257). With this understanding, there may come a corrective from Gibson-Graham and their allied researchers. They have posited a performative process to conceive of the economy "as a situated and diverse space of ethical decision making and negotiated interdependence [emphasis mine] with other humans, other species, and our environment" Gibson-Graham et al. (2013, xix). Thus, the economy - rather than envisioned as a logical machine whose valves 
just need to be adjusted or an engine fueled by growth (ibid, 2-3) - becomes again a space of agency. In the academic sphere, the process has three main components:

- Ontological reframing of economy can be used to reject pro forma conceptions of economy and incorporate non-capitalist elements;

- Reading for difference can bring to the fore elements that had been subordinated or considered ancillary by dominant discourses; and

- Thinking creatively about issues - often bringing together ideas from different domains and disciplines - to generate new possibilities. (Gibson-Graham 2008, 8-14).

Through work on diverse economies, Gibson-Graham have sought to highlight how people can identify themselves as actors (in multiple ways) in the economic spheres they are part of. See the conception of this as the proverbial tip of the iceberg, with just the facets of the "formal" economy above the waterline and most of what comprises the economy below the surface (Gibson 2016).

Following from Beckert and from an understanding that embedding is a social process to be engaged in by practitioners and communities, it is useful to note that Gibson-Graham et al. published Take Back the Economy as a guide to that end. It was written for groups of people considering approaches to re-frame the economic realities of their communities (via ethical action). The purpose of this is to understand that economies can be shaped by individuals and communities and can be the outcome of agency exercised to create a socially and environmentally just world (Gibson-Graham et al. 2013, xiii). The salient questions they developed for creating a community economy, (ibid, xiii-xiv) are adapted below :

- How do we survive well?

- How do we distribute surplus?

- How do we encounter others as we seek to survive well?

- What do we consume?

- How do we care for our commons?

- How do we invest for the future? 
Figure 2: The economy as represented by an iceberg

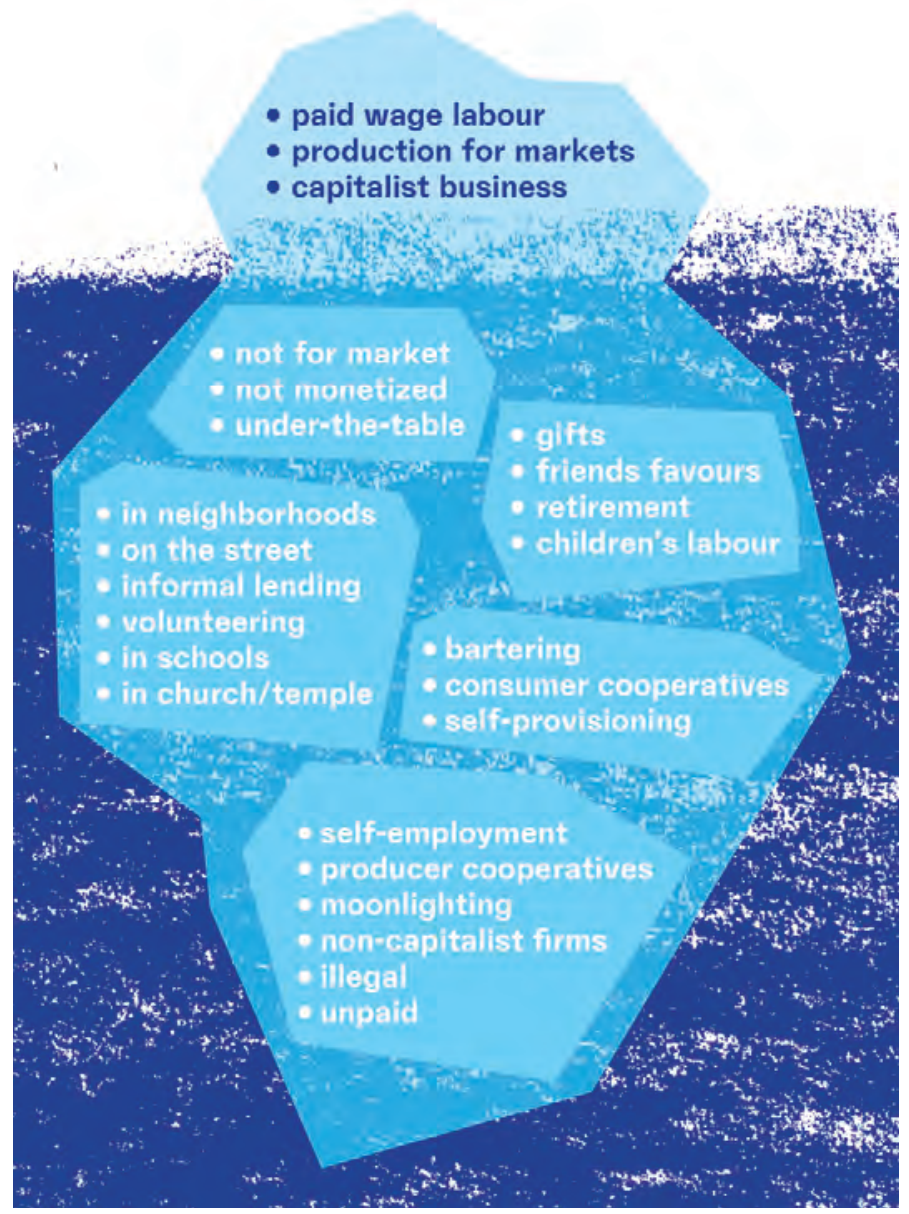

Designed by James Langdon for Trade Show ${ }^{30}$

In these questions, there is clearly a focus on (or even presumption of) autonomy and some degree of control over community resources, which may or may not be geographically situated. Further implicit in these questions are some understanding of who and what constitutes the community; the need for mechanisms for participation in that community (actively or passively); and the need to develop understandings beyond addressing immediate needs. These are issues that cooperatives also have taken up as important concerns. They are often explicitly

\footnotetext{
${ }^{30}$ Design by James Langdon in return for Katherine Gibson's 'The Economy as an Iceberg" essay for Trade Show, curated by Kathrin Böhm and Gavin Wade, Eastside Projects, Birmingham, December 2013.
} 
reflected in their mission statements and in internal conversations at their member and management meetings. Retail food cooperatives concerned about their communities must consider the agricultural processes and systems that provide their products. As such, I now return to the discussion of "doing embeddedness" in the context of the food system.

\section{6: Embedding the food system}

In the context of food and agriculture, embeddedness has become differently defined and much less focused on understandings of how economic transactions occur in the social world. Instead, it has come to signify a number of relational understandings (including proximity, quality, authenticity, and connection) between a food product or food system and a territorial or geographic place or a sociocultural network. As in economic sociology, embeddedness in the food system has been conceptualized in a variety of ways, a few of which are mentioned here.

- Embeddedness may be viewed as having vertical and horizontal components (Bowen 2011) - where vertical embeddedness is the legal and regulatory backdrop in which local food activities exist, and horizontal embeddedness would represent such things as the cultural, social, and ecological backdrop in which food provisioning occurs. Action to affect change can occur within both the vertical and horizontal spheres (Sonnino and Marsden 2006, 189190) of such a food environment, and thus offers a site for contestation, human agency, and social action. Tregear and Cooper (2016) have also described similar conditions as "sectoral embeddedness" in their study of agricultural producer co-ops. Sectoral embeddedness would signify the cultural and organizational attributes of particular agri-food sectors, including the behavioral tendencies toward interaction, cooperation, and learning in networks of people.

- Feenstra's prescriptions for a connected food environment - while not explicitly using the term "embeddedness" but calling for community food systems (2002) - also urge a holistic approach to building sustainable food systems that create and protect social space, political space, intellectual space, and economic space to build the social capital needed in a community food system. Feenstra's focus on (public) participation, partnerships, and principles (of justice and community wellbeing) allows room for a 
wide variety of actors - growers and producers, private individuals, civic organizations, business, governmental entities and academics - to advance the hopes for food system sustainability over time.

- Sonnino has also described embeddedness as a socially constructed process that also has territorial, spatial, and temporal dimensions, rather than being a static given condition. Her study of saffron production shows how a food product can "become embedded through a process of mobilization of values and meanings" and "must continuously be defended and reinvented," whether through negotiated networks that might themselves have conflicting interests or through formalized branding (2007b, 6-7).

- Roep and Wiskerke (2010) cite socio-material resource embeddedness to indicate distinctions between things such as soil type and distinctive animal breeds inherent in production processes and that can also influence the organoleptic properties of a food product. These ideas are also related to the concept of terroir - which has spread from the wine industry to other discussions of foodstuffs - and signifies both the environmental conditions and the agricultural and husbandry practices of production.

- Renting et al. have elaborated a concept of spatial embeddedness for globally traded foodstuffs. This form of embeddedness carries ideas usually associated with short food supply chains (even at extended distances). They include presumptions not only of trust and quality, but also of ecological methods of production. Examples include Parmagiano Reggiano cheese and fair trade products (in the former) and organic and GMO-free (in the latter). In such cases, distance is less important than that products are "embedded with value-laden information when it reaches the consumer" ..., and that such "information allows products to be differentiated ... and command a premium price if the encoded information is considered valuable by consumers" (2003, 399-401).

Penker has offered an interesting idea of ecological embeddedness that critically addresses the tendency to exclude conventional production from discussions of embeddedness, in favor of alternative food networks. Her article (2006), beginning with a survey of embeddedness literature, highlights that other writers have 
discussed embeddedness as social, spatial or ecological in nature but that these traits usually overlap or are found in combination. Penker presumes that even the most neoliberal of food chains are similarly embedded in all three, "interlinked with the socio-institutional and ecological context of their respective locations" (ibid, 370).

Penker's study describes embeddedness with the unit of analysis as the landscape, a concept that incorporates - at least in the European context and through the European Landscape Convention - ideas of nature, identity, and livelihoods. Penker's study includes an area of Austria hosting the production capacity of two bakeries whose products are well regarded. Though they produce conventional (here, meaning non-organic) bread, their ecological footprints had been mitigated by a raft of environmental measures around waste reduction, energy sourcing, and pollution controls. These bakeries also produced bread at larger factories that offered higher energy efficiencies in some parts of their operations than smaller factories did (Penker 2006, 376-377). Additionally, their retail operations were vertically integrated through specialized bread shops that offered face-toface relationships that customers prized and that mirror the relations of regard often presumed in alternative food networks. The ecological focus in Penker's approach to embeddedness also connects to an important facet in the theory of diverse economies: a basic urgency of diverse economies is to understand that corrective human agency in the Anthropocene must include care for non-human species and the planet (Gibson-Graham et al. 2016).

\section{7: Global versus local... What's in a name?}

In academic literature related to food and agriculture, embeddedness has also taken on a meaning that reflects a binary discourse between a globalized food system lacking a sense of or identification with place and an "embedded" localized system reflecting niche production and an emphasis on quality. This is reflected in the idea of a "placeless foodscape" to signify contrasts of rootedness, and culture (Friedmann 2007; Ilbery and Kneafsey 2000; Morgan et al. 2008). Accordingly, many arguments for more sustainable and resilient food economies are closely aligned with understandings of integration with the economic, social, and environmental particularities of specific places (Feenstra 2002; Sage 2003; Holloway and Kneafsey 2004). This is a hallmark of the local food movement and one that is being used in the cause of economic development, including strategically in rural areas with 


\section{4 | Chapter Two}

otherwise fragile economic livelihood opportunities (Murdoch et al. 2000). This can clearly be seen in the use of regional protection and designation labelling in Europe such as PDO and PGI, ${ }^{31}$ which denote certain standards or understandings of quality in different contexts (Ilbery and Kneafsey 2000; Sage 2003; Sonnino and Marsden 2006), though they may or may not be steeped in an territorial context or geopolitical boundary.

Discussions of embeddedness may use other linguistic proxies for the drive to support local food provisioning or efforts to "(re)localize" food and food production. The drive to (re)localize comes from several quarters, in part because (re)localization is often posited as either alternative or oppositional (Sonnino and Marsden 2006) to a global industrialized food paradigm. This paradigm, characterized in political economy as the corporate food regime (Friedmann 1993a), is responsible for many externalized effects that damage societal, economic and environmental health and wellbeing the world over (Magdoff et al. 2000; Holt-Giménez and Shattuck 2011; McMichael 2009b). Thus, in many ways, local food has become the signifier to heal the woes of the dominant capitalist industrial food system.

Many authors have demonstrated, however, that the framing of food provisioning and consumption as either alternative or conventional/industrial sets up a false dichotomy (Johnston 2008; DuPuis and Goodman 2005; Sonnino and Marsden 2006) and is subject to conceptual compression - the cursory overlaying of particular attributes on a system of production (Hinrichs 2003). As such, it is not especially surprising that imprecise language abounds in discussions of AFNs. Indeed, conventional and alternative are not completely opposite in their structure and functioning, nor are they purely and exclusively devoid of elements of the other. For example, organic production has been the most prominent expression of the alternative food movements, but the rise of big organic producers - who use many of the same systems decried by others in the food movement (such as exploitive labor practices and large-scale mono-cropping) - have brought to light questions about its corporatization and environmental impact (Johnston et al. 2009, 510).

Local food provisioning is a prime vector for alternative food ideas. With local food, as with "alternative food," there is a great potential for unreflexive thought

\footnotetext{
${ }^{31}$ Further information on Protected Designation of Origin and Protected Geographical Indication labelling may be found at http://ec.europa.eu/agriculture/quality/schemes/index_en.htm
} 
and action around ostensibly praiseworthy aims. As discussed by Dupuis and Goodman, "normative localism places a set of pure, conflict-free local values and local knowledges in resistance to anomic and contradictory capitalist forces" (2005, 359). Uncertain attributes might uncritically characterize local food and alternative food provisioning as being safer or more nutritious (Nygård and Storstad 1998), innately socially just (Allen 2010), or more authentic (Holloway and Kneafsey 2004) - regardless of the actual circumstances. Hinrichs also cautions against a localization that develops along more provincial or protectionist patterns, engendering a "defensive localism" rather than a "diversity-receptive localism" that could inadvertently encourage separatist politics (2003, 37). Additionally, at work in alternative food movements, there can exist an undertone of morality (Jochnowitz 2001), responsible citizenship (Johnston 2008; Wilkins 2005), and orthopraxy (DuPuis et al. 2006; Guthman 2008) in using the "correct" ways of food provisioning.

Instances of direct-to-consumer agricultural marketing have been primary channels of conceptualizing embeddedness and locality in AFNs - resulting in numerous studies of farmers' markets and CSAs (Renting et al. 2003; Sage 2003; Watts et al. 2005; Whatmore et al. 2003). The focus on upstream production actors has played an important role in the emphasis given to agricultural-based actors in the food system as change agents and limiting the possible influence of downstream actors (such as consumers), particularly in the earlier days of "alternative" food movement literature (Tregear 2011, 9; Little et al. 2010, 1798-1799). Elements of esteeming such production actors are exemplified in the creation of a "Supermarket Pastoral" idyll of food (Pollan 2006, 137) - one that mythologizes both the farm and the farmer, but seldom the farm worker! Perhaps it is due to their expressly (but not exclusively) commercial orientation that co-operatives - which may be just as interested in systemic change as in food provisioning and which may focus on local food in the manner of AFNs - remain understudied. Indeed, there is ample room for more reflexive thinking on what locality can mean.

\section{8: Economic action still on the alternative food menu}

While understandings of embeddedness and locality are constructed, negotiated, and reinforced (Hinrichs 2003; Sonnino 2007b), it is not to say that characterizing economic transactions has become irrelevant to scholars of food and agriculture. Indeed, as pointed out by Hinrichs, a more robust discussion of embeddedness observes that price remains present, even in interactions with "vigorous, meaningful 
social ties" $(2000,297)$. Scholars have written about the need to look more critically at various economic issues in the alternative food world, including how differences in instrumentalism or marketness influence producers' participation in various sales environments (Thornburg and Ramsey 2013); the moments of economic exchange and the power relations that accompany them (Hinrichs 2000); and processes of scaling up alternative food networks to make them economically viable and selfsustaining (Crabtree et al. 2012; Day-Farnsworth et al. 2009; Friedmann 2007).

It is important to note that the idea of embeddedness should not be conflated with the automatic presumption of trust in economic exchange. Granovetter emphasizes that networks of actors can indeed encourage economic interactions, generate trust, and discourage malfeasance, but actors still mainly rely on generalized information about exchange partners - all the while seeking better information about a potential transaction partner $(1985,490)$. Granovetter saw some of this trustworthiness as communicated by institutional arrangements or contracts within and between firms (ibid, 489). For example, there are numerous certification processes and regulatory bodies that offer information to many different actors along the production and consumption chain (Bacon 2010; Hatanaka and Busch 2008; Le Heron 2003). However, Granovetter goes on to say that the very trust that might exist presents an "enhanced opportunity for malfeasance" $(1985,491)$. With respect to alternative food provisioning, there have been highly visible incidences of fraudulent or dubious organic food - whether arising though outright law breaking, lax standards, unintentional contamination, or rule exemptions and modifications for what is allowed in organic production. ${ }^{32}$

Embeddedness also should not be conflated with non-capitalist exchange or with equality among transaction partners. Hinrichs's examination of directsale agricultural markets (2000) highlights the incongruities of power that social embeddedness can obfuscate. Also, citing Bonanno et al. (1994) and McMichael (1994), Hinrichs observes that "Too often, marketness and instrumentalism are seen as the currency only of powerful, but faceless players in distant reaches of the dominant global system" $(2000,297)$, rather than also existing in transactions

\footnotetext{
${ }^{32}$ For changes in the EU context: http://www.eubusiness.com/news-eu/italy-environment.dwq https://www. theguardian.com/uk/2009/sep/22/director-jailed-fake-organic-food https://www.euractiv.com/section/ agriculture-food/news/gmos-and-pesticides-could-be-tolerated-in-organic-food-under-new-eu-rules/ For more on the US context: http://www.nytimes.com/2012/07/08/business/organic-food-purists-worry-aboutbig-companies-influence.html?_r=2\&pagewanted=all http://www.mcclatchydc.com/news/nation-world/national/ economy/article24734608.html
} 
between actors with close ties or in close proximity. As such, Hinrichs warns that a presumption of embeddedness may de-emphasize manifestations of marketness or instrumentalism in the alternative food world or assume these traits to be "morally negative" by default (ibid, 301). 
Overleaf: Farmer observing the land at the farm of La Semilla Food Center, a community development organization 
This chapter introduces the concept of framing as a method of sensemaking used to describe and "diagnose" issues and problems, what their boundaries and cause are, and what can be done about them. I use an actor orientation to explicate how multiple realities contribute to framing. I discuss my use of thick deception to aid the interpretive nature of this research. I discuss my site selection and detail my data generation and analysis. This chapter also includes graphical information to introduce the physical environment of the case studies in New Mexico. This is on a general level, leaving more details of each site to the following chapters (4 and 5).

\section{Chapter 3: Research Methodology}

\section{Overall Research Approach}

To reiterate the overall research approach, this study was devised to investigate retail food cooperatives' framing of local food and the various practices they may employ in local food provisioning. As such, this requires narrative or descriptive data - rather than numbers and statistical information - and appropriate corresponding methods of data generation and organization. During this process, I employed a qualitative research strategy using specific case studies that could help elicit, among other things, possible understandings of what constitutes local food, according to the cooperatives studied in their specific contexts. Therefore, what follows - along with a description of my case selection, data generation, and analysis methods - is a discussion of an actor-oriented, interpretive approach and the use of framing as integral to the overall methodology.

\section{1: The food regime and the resistance}

Food regime theory - a political economy analysis of how global systems of food production and consumption are essential to the workings and perpetuation of capitalism - was devised by Harriet Friedmann (1987) and later expanded on by Friedmann and Philip McMichael (1989). It describes a globalized food system that is foundational to expansionist and dominant forms of capital accumulation, wherein links between large-scale economic actors are buttressed and made more powerful (Murdoch et al. 2000). Though there have been different sorts of food regimes described as ascendant throughout history (Friedmann 2005; McMichael 2009b), regimes are solidified among key players with shared understandings and aims - though Friedmann points out that relationships among those players also bring internal tensions that eventually lead to crisis and transition (2005, 228-229). 
Particular discourses, models, and institutions also serve to legitimate and reinforce regimes though regulatory systems and policies, international trade bodies, and big agribusiness. In the case of the corporate food regime described by Holt-Giménez and Shattuck, these include

“Northern-dominated international finance and development institutions
(e.g. IMF, WTO, World Bank), as well as the major agri-food monopolies (e.g.
Cargill, Monsanto, ADM, Tyson, Carrefour, Tesco, Wal-Mart), agricultural
policies of the G-8 (US Farm Bill, EU's Common Agricultural Policy), and big
philanthropy capital (e.g. the Bill and Melinda Gates Foundation)” (2011, 119).

Clearly the scale and the influence of these organizations are enormous. As Friedmann points out: "Food regimes and other approaches help to recognize the legacies of institutions, which have arisen, layer on layer, into a complex present" (2013). In this way, food regime theorists have contributed greatly to an understanding of the interconnected structures that have, for decades, largely determined what food is available, to whom, and at what costs.

While the conceptualization and description of global agricultural systems have been useful in understanding the scale and power of global networks (McMichael 2009b), regime theory does not acknowledge the interplay of macro-level (global, regional, or sub-national) social actors with those operating on a micro level. Indeed, recent discussions about food regime theory question its continued use in its current form (Friedmann 2016). Rather than influence and power going in one direction (the "powerful global" [macro] actor controlling the "weak local" [micro] actor), there is an interplay in which structures and processes are interpreted and re-interpreted in the life-worlds of social actors (whether individuals or organizations) on different scales (Gibson 2016). This mutual influencing highlights the human agency of micro level actors (Arce 1997) - such as many alternative food movements - even in highly subordinated situations not of their own making. This human agency through whatever verbal or non-verbal discourse - could serve to reinforce or to subvert the social processes present in the situation (Long 1990). An example of this mutual influencing can be seen in organic agriculture (Smith 2006). While a corporate-organic foodscape has co-opted ideas of environmental sustainability, low-input agriculture still offers a powerful social critique that can "motivate a collective challenge" to neoliberal choice thinking (Johnston et al. 2009, 528). 
Even in similar circumstances, human agency can lead to varied strategies and, thus, can potentially produce different outcomes. These strategies "reflect variations in the ways in which actors attempt to come to grips, cognitively and organizationally, with the situations they face" (Long 1990, 10). In this way, the reasons for exercising that agency remain important and specific to their contexts. The strategies of social actors are not necessarily ideological or intended to create conditions beyond the hoped-for benefits imagined by those participating in such strategies. Buying organic tomatoes from a roadside stand does not make one a revolutionary. In the case of this particular research, using an actor-oriented approach aids in examining what cooperatives are doing related to local food and what their rationales are for that engagement.

\section{2: Actor orientation}

Given my research questions and theoretical perspective, it was critical to use an actor orientation in my fieldwork. As part of this orientation, I (as a researcher) have limited ability to make knowledge claims. As such, I must interpret the reported observations and the reported interpretations (of events and observations) of the informants in my case studies. The reason for this is to apply reflexivity vis-à-vis the inherent bias that I (as a researcher) bring to the fieldwork and writing process in examining social actors. In recognizing a focus on the meanings (as created, understood, and applied in the practices of the specific co-ops in this research), it became clear that an interpretive approach ${ }^{33}$ would be useful. The interpretive approach "is concerned both with empiricism... and with meaning-focused analysis" (Long 1990, 10).

Social actors, as Long describes, are associated with social constructions that emerge either endogenously from the "representations characteristic of the culture in which the particular social actor is embedded" or from the researcher's "own categories and theoretical orientation" $(1990,9)$, which can have important reflections on what constitutes the elements of agency (Yanow and Schwartz-Shea 2014 , xiv). The recognition of agency is key to maintaining an actor-orientation in

\footnotetext{
${ }^{33}$ There is considerable discussion in the interpretive research community that interpretive research methods should not be construed as a subset of qualitative research. This view is based on both the historical underpinnings of the methods developed for "non-quantitative" research techniques and the increasing tendency of qualitative research methods to reflect some positivist "quantitative" processes, such as the use of a priori theories and applying large ' $n$ ' practices to small ' $n$ ' studies (e.g., Q methodology). This thesis will not concern itself with threshing out that argument, but see "Wherefore 'Interpretive': An Introduction" in Yanow and Schwartz-Shea (2014) for an overview.
} 
the research. It is through what social actors choose to do - which will differ from one actor to another, even among those in the same or similar circumstances that creates and reifies the realities in which those social actors are functioning. In this way, a hallmark of interpretive research is the acknowledgement of multiple realities existing at the same time, as the actors involved are agents in the creation of those realities.

As Long $(1990,9)$ details, the realities of social actors are constructed (interpreted and re-interpreted) through the interactions with other social actors that are specific to the operational context. By assuming that social actors have agency derived from learned knowledge and capability, one can examine the process of "knowledgeability" employed by said actors, wherein "experiences and desires are reflexively accorded meanings and purposes" (Long and Cruz 2003, 49). This is part of the process of decision-making and justifying arguments or rationales for given actions or modes of thinking. Furthermore, these actions and modes of thinking are determined by verbal and non-verbal 'discursive means: objects, entities, or activities that demonstrate ideologies and arguments guided by those meanings (ibid, 48). In this way, social action incorporates both a meaning and a practice or action (Long 1990, 9). Furthermore, the meanings used by social actors are created by verbal and non-verbal language (Long 1990, 3), including written text, images, and behaviors. And it is in language that problems and issues are framed, as well as what can or should be done about said problems. "By rendering events or occurrences meaningful, frames function to organize experience and guide action, whether individual or collective" (van der Stoep 2014, 52). The co-ops use verbal and non-verbal language to frame the issues that they see as germane to local food provisioning. They offer frames that can be analyzed to explore how their rationales about local food provisioning justify or condition their actions. Thus, this necessitated analyzing both what co-ops say about local food and what they say they do in the name of local food.

\section{3: Framing uses and processes}

Framing is a method of sensemaking (Weick 1995) that social actors (whether individuals, organizations, etc.) use to help to understand and justify the practices they employ regarding complex problems. According to Entman (1993, 52): "To frame is to select some aspects of a perceived reality and make them more salient in a communicating text, in such a way as to promote a particular problem definition, 
causal interpretation, moral evaluation, and/or treatment recommendation for the item described." Thus, understanding framing is about analyzing language used regarding a phenomenon or situation. "By rendering events or occurrences meaningful, frames function to organize experience and guide action, whether individual or collective" Snow et al. $(1986,464)$. While framing processes prevalent in sociological literature have found particular currency in media studies, politics, and journalism (Fenton and Langley 2011), they are also used in sustainable and alternative food literature (Ryan et al. 2001; Chyi and McCombs 2004; Tankard 2001; Scheufele and Tewksbury 2007). Inherent in communities concerned with alternative food - whether academic, activist, or policy - is an understanding and discourse regarding "what is wrong" or undesirable about ways of food provisioning and consumption that lie outside of that alternative food circle. Framing provides a way to specifically examine those perspectives.

In their influential work "Frame Alignment Processes, Micromobilization, and Movement Participation," Snow et al. claimed that much of the literature analyzing social movements' frames leaves out important elements in their explanations. ${ }^{34}$ Specifically, those frames give inadequate attention to how issues, problems, or grievances were framed: "They neglect the process of grievance interpretation; they suggest a static view of participation; and they tend to over-generalize participation-related processes" (1986, 465). The over-generalized view neglects the multiple realities of diverse actors that interpretive research is so keen to help describe. A static view of issues and grievances further neglects the dynamic learning that can happen in the process of construction of frames - especially as new information is discovered - and pays short shrift to how they are applied by those social actors in constructing those multiple realities. The task of correcting for this in framing is an element essential to elucidating those multiple realities that undergird calls to action and justifications for said action. This is further bolstered in the work of Gibson-Graham and Roelvink describing a "project of visibility" that uses framing and re-framing of issues as a pre-cursor "to widen the field of possibility for economic activism and development" $(2009,4)$.

\footnotetext{
${ }^{34}$ The work of Snow et al. on social movements and social movement organizations is being applied here to the "local food movement" and to retail food co-ops that are engaging in local food provisioning. The issue of whether food co-ops themselves qualify as a movement will be addressed in the discussion section of the thesis, though the genealogy of the cooperative movement itself was discussed briefly earlier in the Introduction section.
} 
The recognition of framing as a precursor to understanding action led me to choose informants working in different areas of my field sites. Through interviews with various actors in the La Montañita Food Co-op and the Mountain View Market Co-op, what emerged were varied conceptions of local food and how the different roles of co-op staff members - and their interactions with other staff, their vendors, and their institutional customers - helped to elucidate their practices related to local food. It became clear that different functions and parts of the organization had different interactions with (and ideas about) local food. The multiple realities of local food support using an actor orientation and highlight that agency exists on an organizational and an individual level.

I turn momentarily to a theoretical discussion to explicate what my informants were talking about when they referred to local food in interviews. As described in the schematic below Dewulf et al. (2009) encourages researchers to inquire about the nature of the frame used (cognitive or interactional) and what is being framed (issues, identities and relationships, or interaction processes). Dewulf et al. employ an ontological distinction between cognitive frames (relatively static knowledge structures or cognitive representations) and interactional framing (the dynamic process used to co-create meanings in interaction.

Table 10: What is it that gets framed?

\begin{tabular}{|c|c|c|c|}
\hline Nature of frames & Issues & $\begin{array}{l}\text { Identities and } \\
\text { Relationships }\end{array}$ & Process \\
\hline $\begin{array}{l}\text { Frames of cogni- } \\
\text { tive representa- } \\
\text { tions }\end{array}$ & $\begin{array}{l}\text { 1. Cognitive issue } \\
\text { frames }\end{array}$ & $\begin{array}{l}\text { 2. Cognitive identity } \\
\text { and relationship } \\
\text { frames }\end{array}$ & $\begin{array}{l}\text { 3. Cognitive process } \\
\text { frames }\end{array}$ \\
\hline $\begin{array}{l}\text { Framing as } \\
\text { interactional } \\
\text { co-construction }\end{array}$ & $\begin{array}{l}\text { 4. Interactional issue } \\
\text { framing }\end{array}$ & $\begin{array}{l}\text { 5. Interactional } \\
\text { identity and } \\
\text { relationship } \\
\text { framing }\end{array}$ & $\begin{array}{l}\text { 6. Interactional } \\
\text { process framing }\end{array}$ \\
\hline
\end{tabular}

(Dewulf et al. 2009, 166, adapted)

Zwartkruis (2013) has described cognitive frames as occurring "between the ears" of a person (i.e. in the mind) and interactional framing happening "between the noses," with the later offering a vision of ongoing negotiation between one or more parties. Cognitive frames distill beliefs about external reality, while interactional framing is a co-construction process of sensemaking (Dewulf et al. 2009, 8). Yet because a researcher cannot get inside an informant's thought processes, one is 
reliant on using the professed frames of the informants, thus returning again to the actor oriented nature of this research. In this research, local food is a cognitive issue frame, as informants hold meanings and understandings about it in their particular contexts.

\section{4: Qualitative case studies}

As discussed by Lune et al. (2010): “Qualitative data collection strategies focus on the particular qualities of events and circumstances that cannot be reduced to numbers." So though certain activities that the co-ops engaged in could be expressed in numbers (such as how many local suppliers they worked with over a period of years), there is much more to the story to illustrate and justify their engagement in it. Qualitative approaches are more sensitive to the research environment, offering ways to address "change and flux in social relationships in context and over time" (Seufert et al. 2012, 80). They can thus be more adaptive to issues encountered in that environment than can quantitative ones (Jupp 2006, 249) and allow researchers to study subjects "in their natural settings, attempting to make sense of, or to interpret, phenomena in terms of the meanings people bring to them" (Kumar 2011). Such an approach further supports the actor-orientation of this research by making room for the individual agency of actors participating in a phenomenon, as the cooperatives being studied model. Though researchers of all approaches will develop conceptual frameworks to help specify what phenomena will be studied and how they may be related (Denzin and Lincoln 2000, 3), using an actor-oriented approach does not allow for the use of pre-defined categories and descriptions invented by the researcher, which are hallmarks of quantitative (and not qualitative) data generation/collection (Gray 2004). Next, I will introduce the selected cases and explain the data generation/collection.

\subsection{1: Case studies rationale}

Case studies are used to understand "complex social phenomena" in ways other methods simply cannot, all while maintaining the "holistic and meaningful characteristics of real-life events" (Kumar 2011, 138). Certainly, the frames and narratives used by different actors within a cooperative to think, communicate, and act regarding local food provisioning qualify as complex and also justify Yin's call for using "how" and "why" questions in case studies. Additionally, the research questions focus on contemporary events and cannot be manipulated by the 
researcher. This makes writing a history or performing some social experimentation an unfeasible design (Yin 2009, 4).

The cases used were limited to retail food co-ops that exhibited some interest in natural, organic, or otherwise "unconventional" food provisioning and that had a specific interest in engaging with local food producers. This was to provide a linked context to the previously described "alternative" food movement, which was the focus of my literature review. I used a multiple embedded study design to highlight the differences that might exist between co-ops that shared similar ideological approaches - with respect to being in the natural and organic food sector - but that had salient geographic and demographic differences. The site selection will be explained in 3.4.3.

\subsection{2: Reporting with thick description}

The case studies were written in a detailed manner to take advantage of what Gibson-Graham characterizes as thick description and weak theory (2014). Using Clifford Geertz's influential work on ethnography, "Thick Description: Toward an Interpretive Theory of Culture" (1973) to explain how employing thick description can elucidate social phenomena, Gibson-Graham cautions against inclinations to use "strong theory" that might obscure said phenomena. Strong theory refers to "powerful discourses that organize events into understandable and seemingly predictable trajectories," with the prime example of a strong capitalocentric theorization obscuring diverse economic practices (Gibson-Graham 2014, 148). Here Gibson-Graham illustrates how an account of changes in the labor economy in the Philippines documented by Hirtz (1998) could be interpreted as either an inevitable march toward the proletarianization of the countryside or the maintenance of non-capitalist practices, depending on how those changes are described (thickly or thinly) in their social context. A thin description that speaks of the introduction of cash payments into agrarian life (as evidence of commodified labor) can hide a thicker description of rural labor "supported by familial ties that take the form of payment for work" (Gibson-Graham 2014, 148).

By describing interactions and practices with greater depth and nuance, one can reduce "the risk of bleaching human behavior of complexity" (Gibson-Graham 2014, 148) and move toward "weak theory," which Gibson-Graham characterizes as "little more than description" $(2006 \mathrm{~b}, 8)$. As weak theory invites new possible 
understandings, rather than reinforcing prior knowledge or overlaying broad explanations, it allows "small facts" to address "large issues" (Gibson-Graham 2014, 149). This offers an expanded economic framing wherein different practices can co-exist: "As the impulse to judge or discredit other theoretical agendas arises, one can practice making room for others, imagining a terrain on which the success of one project need not come at the expense of another" (Gibson-Graham 2006b, 8). In such a climate, it becomes possible to understand how minor acts - such as a produce clerk showing a new vegetable supplier how to write an invoice or implementing a distribution plan to increase the delivery range of a CSA - reveal approaches to address systemic concerns in the food system. In practical terms, the use of thick description is evidenced by extensive quotations from my informants. Where quotations appear, I have italicized all quotations and have also indented quotes that were longer than four lines when transcribed.

\subsection{3: Research site selection}

Though there are co-ops that operate as buying clubs with online purchasing, I was interested in co-ops that had an actual storefront with designated trading hours and that accepted custom from anyone, not just members. This is, in part, recognition that such co-ops most mimic a conventional grocery store or supermarket format. Supermarkets remain the primary mode of interaction with the food system for consumers in the US and UK (Michaels 2004; Traill 2006; Schoenborn 2011). So while framings of local and alternative food may be more readily seen at places such as CSAs and farmers' markets [which may also be run as co-ops], there was a utility in studying a retail outlet form that is analogous to where people in the case study areas also buy food.

Between early autumn 2011 and late winter 2013 (early 2014), I undertook both desk-based research and field studies to understand trading environments for retail food co-ops interested in local food provisioning in the United States and the United Kingdom. As English is my only language of fluency, I chose field sites in English-speaking countries to facilitate conducting interviews and investigating the language (verbal and non-verbal) with which co-ops frame local food. Though I did not intend to do a comparative study of these co-ops, I was interested in learning more about the different cultural, commercial, and regulatory environments in cooperative retailing in the US and the UK. (While I ended up conducting approximately 20 interviews for my UK research and about 60 for my US research, 
I have only included US fieldwork in this dissertation, due to better participation from informants there. (See the Appendix for a description of primary informants finally included in this research.)

UK sites

Initially, I had envisioned that the Unicorn Grocery, a worker-owned vegan co-op in Manchester, England, would be my primary UK case, as I had an internship in that city coinciding with the final months of the UN Year of the Cooperative in 2012. Though early on I had very good collaboration and access with Unicorn, personnel changes and pressures of seasonal work demands at Unicorn made it difficult for its staff to continue working with me. I had some promising contact with other UK co-ops, particularly the staff of the "Locally Sourced" initiative at the East of England Co-op located in Ipswich (about 235 miles/378 kilometers from Manchester), but efforts to be in touch at a distance with other staff in key areas of the Co-op were not fruitful after I left Manchester in the spring of 2013. In addition, I had site visits to or contacts with three other UK food co-ops (the Food business of the UK Co-operative Group, Chelmsford Star Co-op, and On the 8th Day food co-op), but those co-ops had little emphasis on local food by comparison.

The preliminary explorations with the UK co-ops proved helpful in considering some potential fieldwork issues and understanding co-op structures. This was particularly so at the worker-owned co-ops whose member-owner base was small enough to have voting participation on a wide variety of management issues. Similarly, the larger customer-owned co-ops highlighted the varied ideas that different departments had about stocking and promoting local food versus nationally known brands. The UK sites also had different conceptions about local food and saw different possibilities of engaging with it. Nonetheless, I ceased pursuing the UK cases by June 2013 in favor of focusing on the US sites.

US sites

The US case studies were located in the state of New Mexico in the desert southwest of the United States. New Mexico is bordered by Colorado to the north, Oklahoma and Texas to the east, the country of Mexico to the south, and Arizona and Utah to the west. I chose to go to New Mexico in order to study the main field site that features in this thesis. La Montañita Co-op Food was suggested to be a worthwhile case through a listserv of US-based retail food co-ops that are members 
of an association called the Cooperative Grocer Network. I posted a message on this listserv in the spring of 2012 asking which cooperatives were doing interesting work around local food provisioning. I received five or six replies from listserv members mentioning La Montañita. Many cited some specific initiatives La Montañita created for their shops, as well as a distribution warehouse and network (the CDC or Co-op Distribution Center) which they manage. ${ }^{35}$ La Montañita is based in Albuquerque, New Mexico (65 miles or 104 kilometers) south of the capital city Santa Fe, but it has locations in Santa Fe and Gallup as well.

La Montañita, in fact, had a strategic growth plan around local food that was created in 2006 and has developed an economically distinctive niche around wholesale and retail local food provisioning, basing much of their approach on an obvious social ethic and an emphasis on co-op values. Indeed, La Montañita had been particularly successful in this strategy, as they opened their sixth location while I was in the field and had plans for further expansion by 2018. I was also interested in looking at other co-ops that represented a different demographic, size and structure from La Montañita's, as all indications were that La Montañita was unique - in its success and in the depth of its work on local food and community development.

I was able to make connections with two other co-ops in the southern part of New Mexico that were also interested in and working on local food in some way. Silver City Food Co-op and Mountain View Market Co-op are both consumer co-ops located in the in the southern part of the state and served by La Montañita's distribution network. By contrast, these co-ops were significantly smaller than La Montañita (in revenue, customer base, and membership). They exist in environments with distinctly different environmental and political issues and are in more sparsely populated areas. Because the Silver City Food Co-op had a very limited engagement with local food, I abandoned that case and chose to focus on Mountain View Market Co-op in Las Cruces (located 225 miles/360 kilometers south of Albuquerque, New Mexico), in addition to La Montañita.

Mountain View Market (MVM) Co-op was a fascinating second case because, in 2011, it bought 2.5 acre (1 hectare) plot of farmland on which it began growing produce through horticulture and aquaponics. Though the MVM Farm produced

\footnotetext{
${ }^{35}$ Though La Montañita is indeed a member of the group administering the listserv and could have possibly seen my request for information, no one replied to my email from that co-op.
} 
food for sale at the Co-op and at local farmers' markets, it also had a very strong public education and training ethos. The aim of this was to increase the number of agro-ecological farmers growing food in the Mesilla Valley region where it is located. The establishment of this farm and its attendant mission of supporting low-input agriculture were also interesting because of its presence in an area of highly industrialized agriculture. "This [area of southern New Mexico] is Monsanto country," I was told by one informant indicating the dominance of productionist, high-input agriculture over agro-ecological techniques.

\subsection{4: About New Mexico}

It is useful to place the state of New Mexico in context both geographically and demographically, though space limitations necessitate a cursory description here.

\section{Map 1: Orientation of New Mexico within the US}

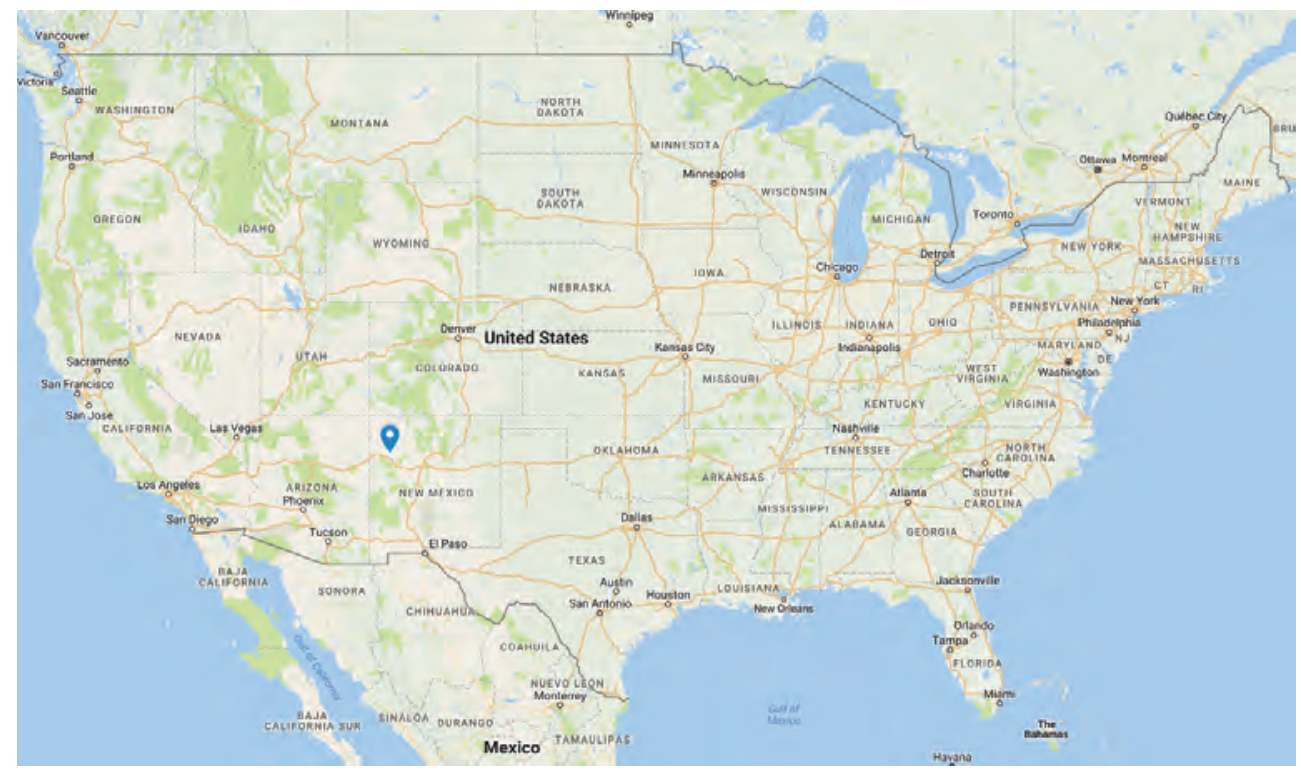

Source: Google Maps, elaborated

The state is located in an arid area of the country, the desert southwest of the United States, and it has significant geographical and climactic features that also make it challenging for agriculture. 
Map 2: Orientation of field site cities (Albuquerque and Las Cruces)

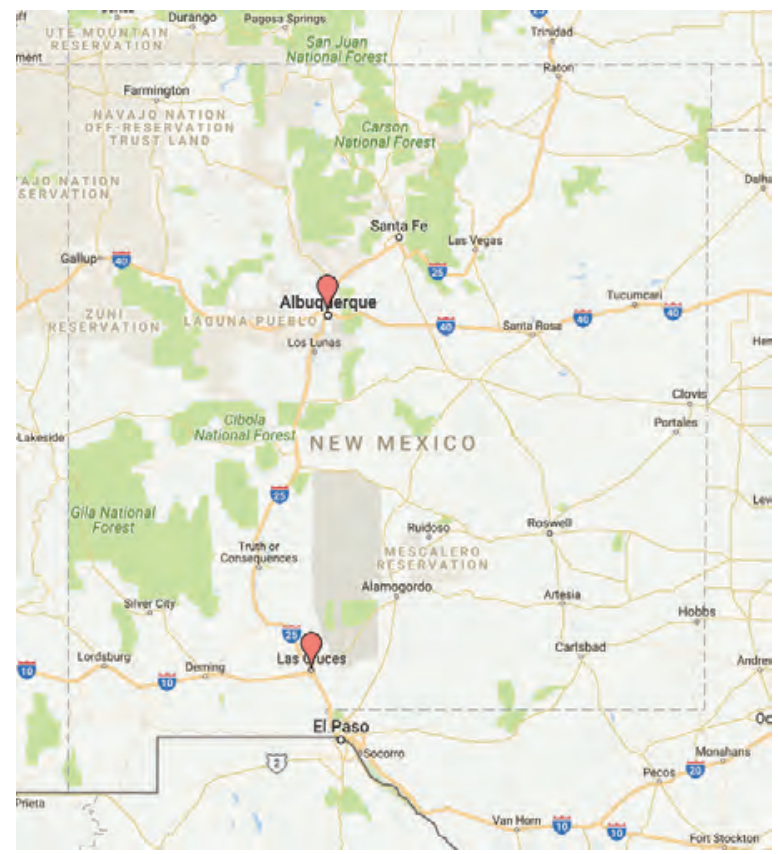

Source: Google Maps, elaborated

Map 3: New Mexico's population density, 2010 US Census

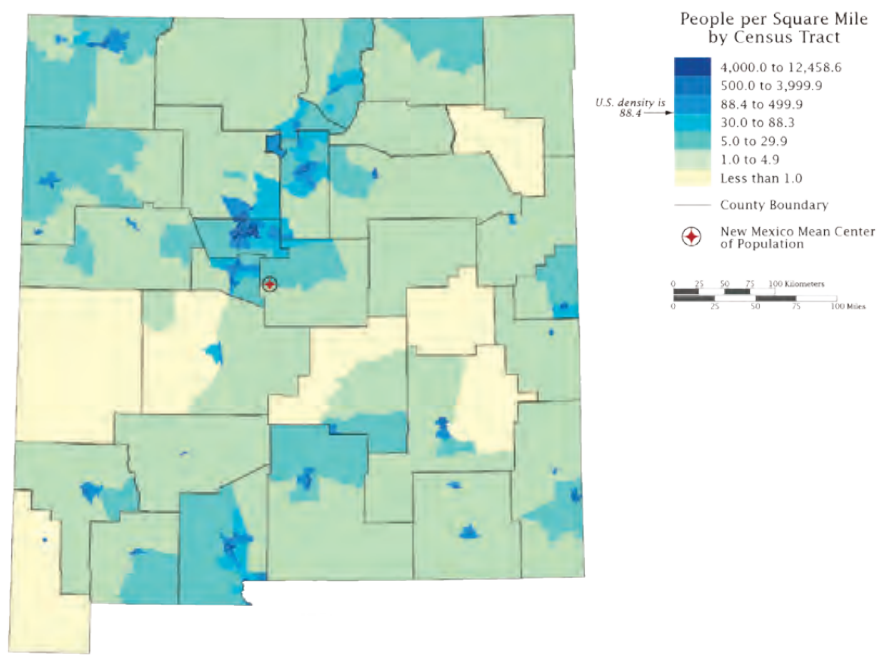

Source: U.S. Department of Commerce Economics and Statistics Administration, U.S. Census Bureau, adapted 
According to the 2010 US Census ${ }^{36}$ New Mexico had a total population of 2,059,179 people living in over 315,000 square kilometers, making the population density approximately 6.6 people per square kilometer. This makes it the sixth least densely populated US state. ${ }^{37}$ For contrast, in 2010, the Dutch population density was 492.6 people per square kilometer.

Most of the state is at a high elevation (averaging 5700 feet, or more than 1730 meters), with the state's lowest point at Red Bluff Reservoir (2842 feet or 866 meters). In an average year, New Mexico receives just 14 inches (approximately 36 centimeters) of precipitation as scant rainfall or snow. As such, $44 \%$ of irrigation water comes from groundwater - in addition to the melted snow that falls on the mountains of northern New Mexico and feeds the Rio Grande River. The Rio Grande, though dammed in several places, runs the length of the state and then forms the

Figure 3: Climactic conditions at the start of US fieldwork

U.S. Drought Monitor New Mexico

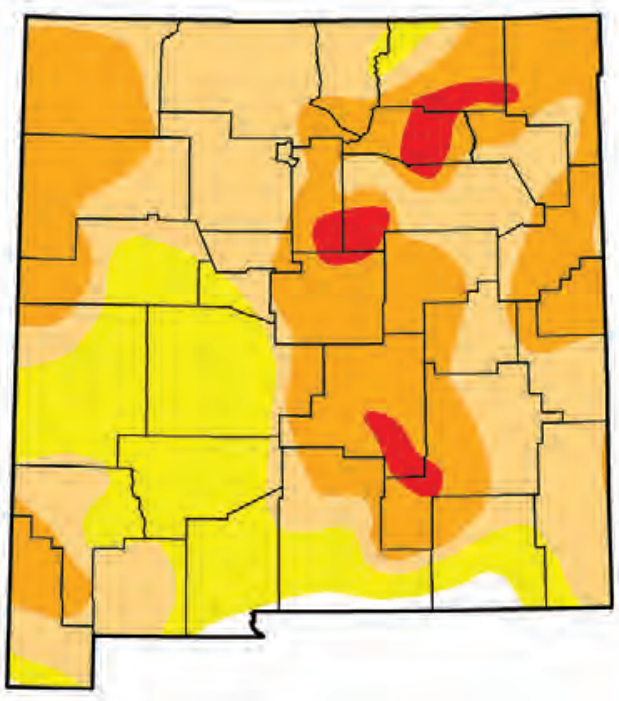

October 8, 2013

(Released Thursday, Oct. 10, 2013) Valid 7 a.m. EDT

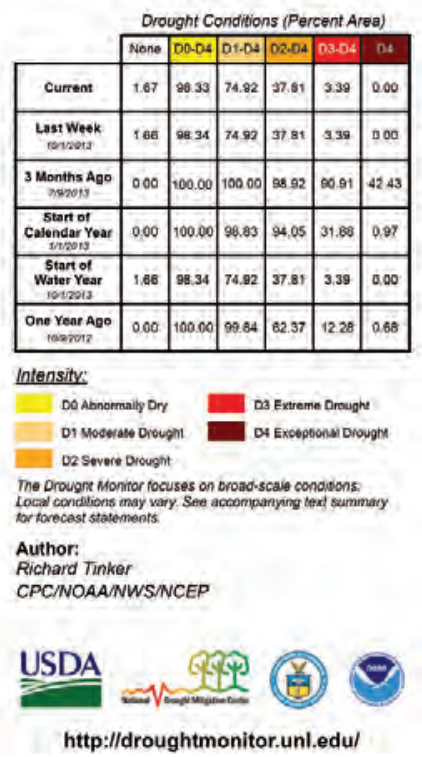

Source: National Drought Mitigation Center at the University of Nebraska - Lincoln

\footnotetext{
${ }^{36}$ Data available at http://www2.census.gov/geo/pdfs/maps-data/maps/2010pop/nm_totalpop_2010map.pdf and also at http://data.worldbank.org/indicator/EN.POP.DNST?locations=NL

${ }^{37}$ This is according to 2010 US Census data http://www.census.gov/2010census/data/apportionment-dens-text. php
} 
border between Texas and the country of Mexico. Though New Mexico is water stressed at the best of times, conditions were even worse at the time of fieldwork, as the state was undergoing a prolonged period of drought.

New Mexico's economy is mainly built on extractive industries (minerals, oil, and natural gas), tourism and retail trade, and significant amounts of government spending in the form of scientific and technical laboratories and military bases. ${ }^{38}$ Even so, agriculture represents a significant sector of the economy, representing about $2.5-3 \%$ of jobs and an output value of 4.26 billion dollars in $2012 .{ }^{39}$

\section{Figure 4: New Mexico's climactic regions and agricultural products}

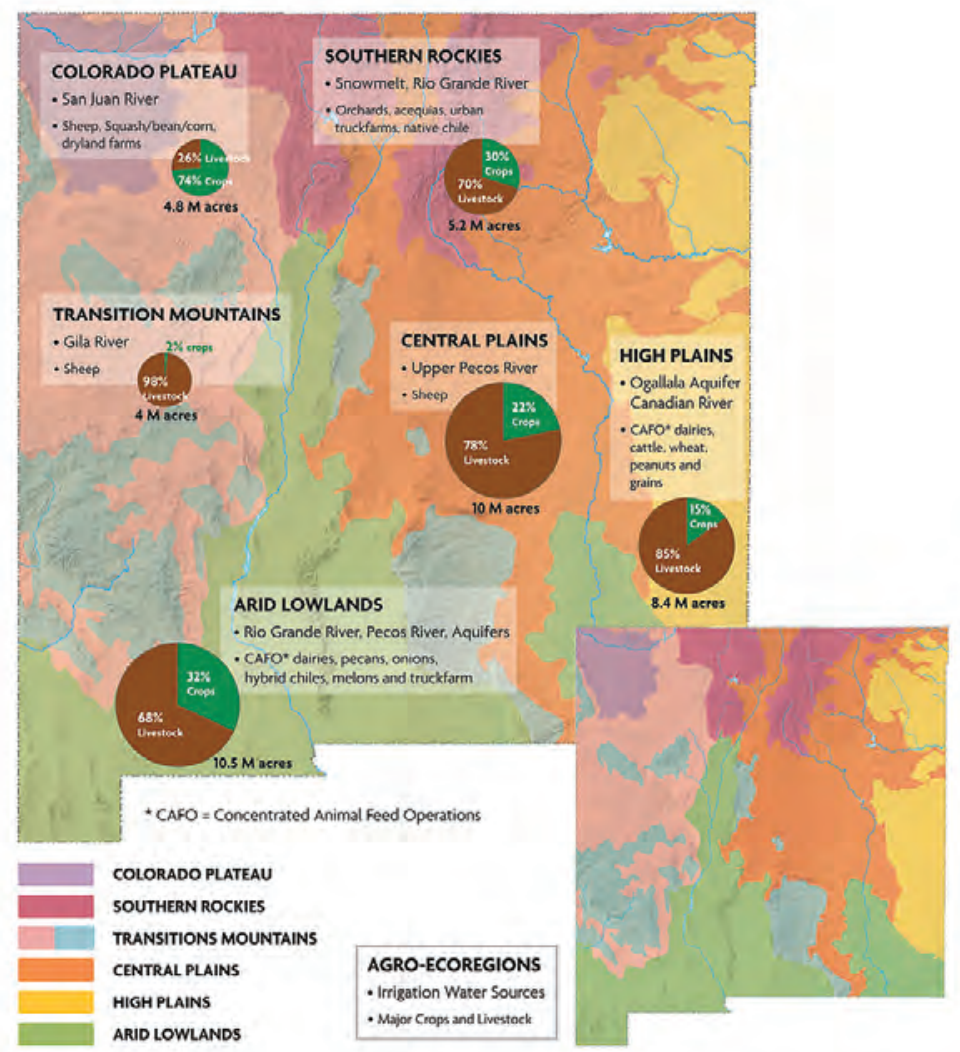

Source: Dreaming New Mexico http://www.dreamingnewmexico.org/

\footnotetext{
${ }^{38}$ New Mexico has large reserves of potash and copper, and has over 320 days of sunshine each year - leading to a surplus of solar energy, which it sells to other states. http://www.investopedia.com/articles/investing/011316/ new-mexicos-economy-6-industries-driving-gdp-growth.asp

${ }^{39}$ It is difficult to get accurate employment figures for agricultural work, which often uses migrant and seasonal laborers who sometimes go unpaid and are counted as self-employed. https://www.dws.state.nm.us/Portals/0/ DM/LMI/Regional_Review_Summer_2014.pdf
} 
Figure 5: New Mexico's top farm commodities by cash receipts

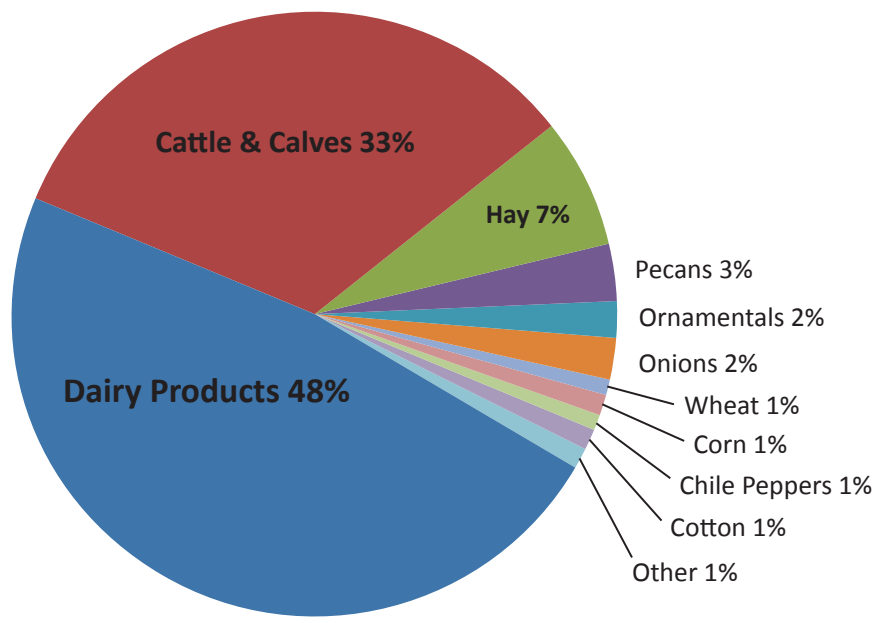

Data and graph (adapted) from Dreaming New Mexico (Bioneers n.d., 5)

With respect to weather, hailstorms and windy conditions imperil farming the most, and wind erosion is a major concern - increasingly so due to climate change. There are, however, diverse landscapes that allow the cultivation and husbandry of different agricultural products, particularly cattle and dairy products.

New Mexico is also a very poor state, routinely in the lowest percentile for indices of deprivation and poverty, including childhood poverty. ${ }^{40}$ New Mexico is home to 19 indigenous (Native American) tribal villages called pueblos and three reservations. This number is down from more than 100 that existed throughout what is now New Mexico when the Spanish colonizers arrived in 1540, according to the Albuquerque Convention \& Visitors Bureau. ${ }^{41}$ Much of the most abject poverty in the state can be found on the pueblos and reservations, these areas having to contend with the legacy of internal colonialism and oppression by white settlement crossing the United States. ${ }^{42}$ There is further historical and geopolitical complexity here because

\footnotetext{
${ }^{40}$ In 2015, New Mexico had the worst US child poverty rate (over 30\%) http://www.santafenewmexican.com/ news/local_news/new-study-finds-new-mexico-has-the-highest-rate-of/article_a81c6cd6-bc2b-55f5-a96a7a90742d2379.html and an all-ages rate of over 21\% https://talkpoverty.org/state-year-report/new-mexico-2015report/.

${ }^{41}$ See https://www.visitalbuquerque.org/albuquerque/culture-heritage/native-american/pueblos-reservations/

42 This is not to say that Native Americans are universally worse off economically than other residents of the state. It is indeed a complicated picture that differs from one pueblo to another. http://www.nmvoices.org/wp-content/ uploads/2013/02/Native-American-Kids-Count-report-2012.pdf
} 
Figure 6: Poverty rates (among all ages) in US counties, 2015

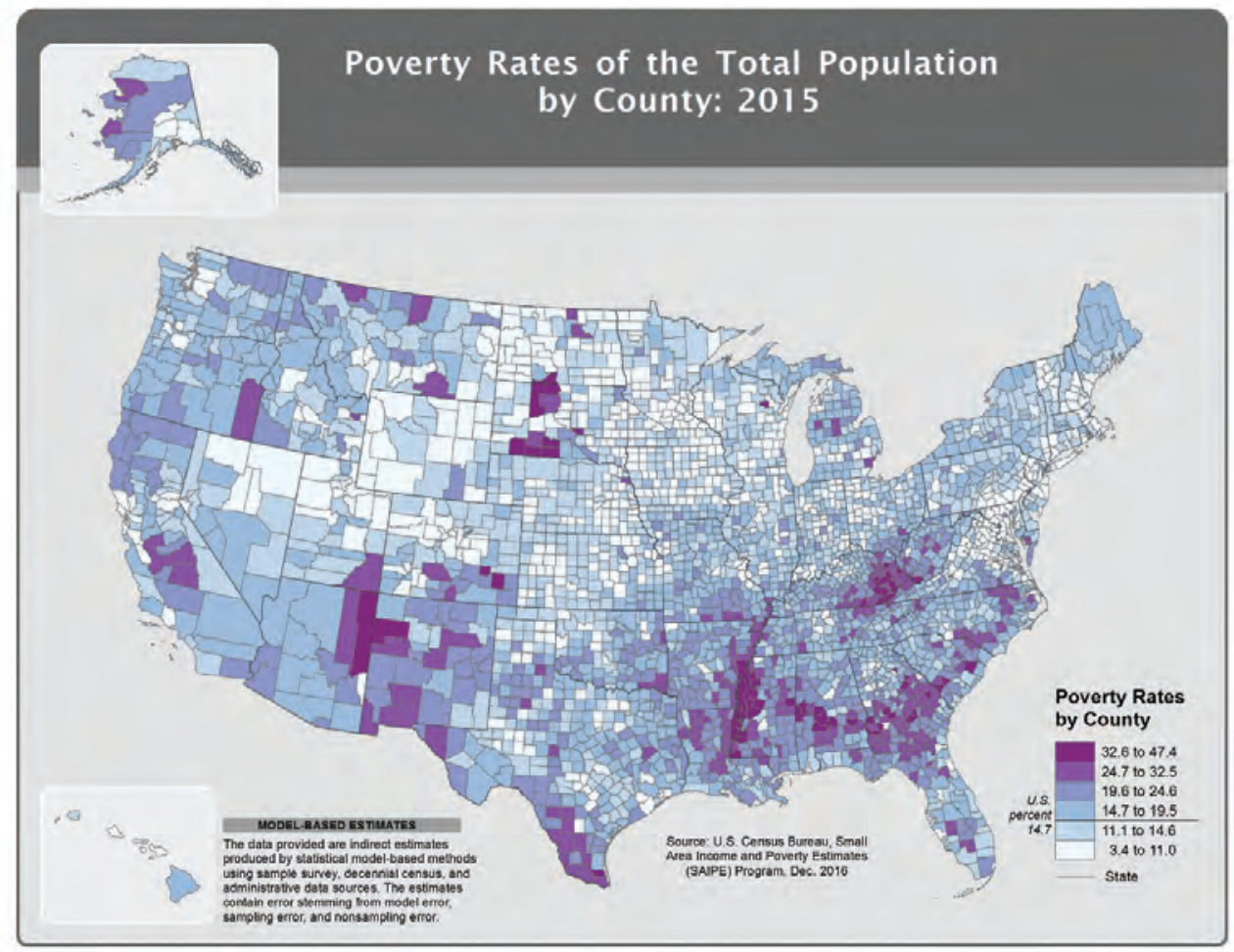

Source: U.S. Department of Commerce Economic and Statistics Administration, U.S. Census Bureau

of the United States' territorial wars and annexation of what was parts of the Mexican Republic, which followed Mexico's own war of independence from Spain.

\subsection{5: Data generation}

All sections in the remainder of this chapter addressing the research process are about the field sites in New Mexico only, where I did fieldwork from October 2013 to early December 2013, with some follow-up phone and email contact through March 2014. In this process, I used interviews, participant observation, audio-visual materials, and written sources to create case studies of these field sites. Before continuing, however, I take a moment to explain the title of this section as "Data generation," rather than "Data collection." This is to acknowledge the interpretive tradition on which this research draws. It is one that rejects the idea that data exist outside of any research project and that researchers simply have to go assemble or collect it, "like some exotic fruit just waiting for the researcher to come and discover and pluck it" (Yanow and Schwartz-Shea 2014, 147). 
Interpretive research emphasizes the role of the researcher as inseparable from the determination of what counts as evidence or data. By the very posing of specific research questions, the researcher privileges and filters (in or out) certain ontological and epistemological approaches (Schwartz-Shea and Yanow 2012). Schwartz-Shea and Yanow also point out that research in this tradition simultaneously engages and prizes perceptions of informants, even as it foregrounds the role of the researcher. Though the researcher's questions help determine what is worthy of attention, by trying to understand the topic at hand "from the perspective of everyday actors," researchers acknowledge and incorporate the expertise of that local actor in cogenerating knowledge $(2012,80)$. This then returns us to the actor-orientation approach of this research.

My main method of data generation/collection was a mix of unstructured and semistructured interviews with informants chosen by snowball sampling. I conducted interviews with a total of 58 subjects, ${ }^{43}$ mainly in-person, with 9 conducted over the telephone or via email. The interviews were made up of open questions, and I took notes and recorded each spoken interview. The majority of informants (31) were staff members and management of the co-ops studied. Four interviews were with officers from co-op support organizations or advocacy groups. Ten interviews were with community group or local government representatives working in agriculture. Thirteen interviewees were local vendors selling to the co-ops or institutional customers (usually restaurants). Vendors included both farmers of food crops and suppliers of value-added or prepared products. Just four vendors I approached refused to participate.

In addition to interviews, I also watched publically available videos of speeches and presentations given by staff and representatives of the co-ops. These were mainly accessed through YouTube and on the Facebook pages or web sites of La Montañita or MVM Co-op and Farm. They were not in the interactional form of an interview, but they do help explicate some issues and offer points for triangulation. I also attended meetings of the board, the staff, and the general membership of the co-ops where I usually did not speak, except to introduce my project and myself

\footnotetext{
${ }^{43}$ I have counted the 8 informants from Silver City Food Co-op in this total, despite not developing a case study of that co-op for inclusion. This is because our discussions were still influential and informed further fieldwork, along with the two co-op cases that were developed for this book.
} 
where requested. (Further details of my respondents will be discussed later in this section.)

The non-verbal language used by co-ops to articulate their work regarding local food is composed of written sources for "internal" audiences (e.g., co-op bylaws, board meeting minutes, and strategy documents) and promotion and marketing materials for customers, vendors, and the public. This included membership information, annual reports, and web sites and newsletters. Additionally, I engaged in a small amount of participant observation at board and membership meetings and while food shopping. Using focused observation, which Werner and Shoepfle (1987) as cited in Angrosino and Mays de Pérez $(2000,153)$ - describe as observation informed by interviews, I concentrated on the co-ops' promotion of local food. I looked for signage in shops (on shelf tags and displays) to see how and whether local products were particularly emphasized. I also asked approximately 10 in-store staff in three co-op locations about the local products on offer and what "local" meant.

\subsection{6: Interview respondents and contexts}

I conducted interviews for the La Montañita and Mountain View Market cases in a variety of settings, including individual and shared offices, on the shop floor, en route to and during community events, and in private homes and local businesses. This allowed me to see a broad expression of each co-op's work with local food and food suppliers and impressed upon me the complexity of their engagement with local food. In addition to this, I also used the office resources at the co-ops studied. I was provided desk space, an Internet connection, and access to their staff kitchens and meeting rooms. Furthermore, I lodged at the homes of co-op staff members during my fieldwork (in one case free-of-charge for 6 days and in another paying rent for one month). This afforded helpful proximity for informal and, sometimes, off-the-record conversations over meals and daily routines. I also commuted with co-op staff members to business meetings, local food events, and visits to other co-ops for nearly three weeks prior to hiring a car for myself.

I interviewed staff members of each co-op who were responsible for interactions with local food suppliers or policies around local food procurement and asked them about their department's work and local sourcing generally. Staff member and management respondents always included the General Manager of the co-op, 
one or more produce managers, and the chief membership/outreach officer. In the case of La Montañita, respondents included both a past and a present general manager and the various staff with job responsibilities that fell within the four areas of work espoused by La Montañita's Long Term Strategic Plan: distribution, market expansion, producer coordination and support, and local brand development. In the case of Mountain View Market, which did not have a specifically outlined local food sourcing strategy in the way that La Montañita did, I interviewed the aforementioned staff and the Kitchen Manager who particularly expressed an ethic of local sourcing.

I also interviewed other co-op staff members who were related to the special initiatives on local food engagement that were unique to each co-op. In the case of La Montañita, this meant staff members of the CDC; for Mountain View Market it meant staff members of the MVM Farm. My questions focused on logistic and practical aspects as well as motivational visions of their work on local food. (See the Appendices for a listing of primary informants from both case studies.)

Aside from the co-ops, I interviewed local food producers selling to the co-ops about their experiences of working with the co-ops. I found my respondents through snowball sampling and mainly depended on referrals and signposting from the co-ops being studied. This is a limitation of doing such work in an unfamiliar context, and there may be a danger that the co-ops would filter out suppliers who have had less positive experiences with them. Through repeating offers to anonymize comments, being as transparent as possible with my own aims, and offering to fact check quotes and anecdotes, I gained trust and was also referred to respondents who did have more difficult relations with the co-ops.

I had very limited input from two main population groups from whom I desired and unsuccessfully sought more input: restaurant and food service customers connected to the co-ops and board members of the co-ops. I was still able to include information on the co-ops' strategic involvement in local food by consulting vision statements and other board documents. I interviewed agriculture and food policy officers and activists working in and familiar with New Mexico to aid triangulation of issues and to provide much-needed context of the historical and political environment for food production in the state. Each informant gave written consent via a form I brought to the interview or sent afterward. I discussed the form, the 
options for anonymity and keeping certain content off the record, including issues of commercial sensitivity. No informants, save one, requested anonymity during the consent process.

Finally, I did not seek individual and household-level customers' input on local food. This is an intentional omission, even though interviewees sometimes used the term "the co-op" when explicitly referring to the member-owners of the co-op. This was mainly in reference to ownership and corporate decision making (e.g., the co-op voted to amend its bylaws), which reflects the co-operative movement's democratic traditions. So though my cases studied are consumer-owned co-ops, conducting customer (member-owner) interviews regarding the framing of local food was beyond the scope of this research. This is because the interview questions were concerned with provisioning of local food - activities not undertaken by customers, but by employees. As such, all data reflect interviews done with management, staff members, institutional customers, or producers/suppliers of products sold through a retail location or warehouse of one of the cases.

\subsection{7: Data analysis}

Chapter 2 of this thesis discussed Gibson-Graham's reframing of economic life as part of the project of diverse economies. In the analysis of my data however, I have employed framing as a strategic methodological tool, and not as a theoretical lens. Taking each field site in turn, I transcribed the interviews of staff working on local food provisioning as my primary data sources. (I transcribed some interviews myself; for others, I hired a transcription company and checked them for accuracy.) I also analyzed some specific written sources, such as La Montañita's Long Term Strategic Plan and a short series of articles written for their Co-op Connection newsletter. Under ideal circumstances, I would have performed a content analysis of other document sources, including advertising leaflets and flyers and web site information. Due to time constraints, I focused on interviews, which offered much richer and more nuanced information.

This was also especially appropriate in the case of La Montañita, because many of the documents I obtained about its local food initiatives were produced prior to a reassessment of the workability of the Long Term Strategic Plan. For example, visions about how the distribution warehouse would work (i.e. via value chains), what types of foodstuffs would come through the warehouse, and other things emphasized in 
early documentation played less a part in the eventual practices than indicated by that documentation. Nonetheless, I did use some of the aforementioned document sources for triangulation of things originally mentioned in the Long Term Strategic Plan and for illustrations of the case study.

Because of the number of interviews and the complexity of La Montañita's operation, I used computer software (Atlas.ti) to aid the coding and analysis of the transcripts for that case study. Having read through each transcript thoroughly and listened to the interviews multiple times, I identified patterns that appeared when respondents discussed engagement with local food (either on an organizational level or an individual professional level). Specifically, the respondents spoke of actual food or food products, food producers and farmers, or the Co-op itself (either organizationally or in reference to its role in the local food economy of New Mexico). Thus, reflecting on Dewulf et al. (2009) to inquire what was being framed - in addition to coding quotations about local food to see how it was spoken of - I also coded for what the respondent was speaking about in each instance. This allowed me to check for patterns of co-occurrences, noting the respondents' tendencies to address different issues in local food, while remaining open to what was said.

Mountain View Market's interviews were fewer in number and tended to be shorter as well. This was owing to the much simpler business operation (one retail location and a farm), having a smaller number of local food suppliers, and the relative newness of its engagement with local food in a concerted way. The coding of those transcriptions was not done with analysis software, though codes were tallied in an Excel spreadsheets. Additionally, the same initial steps of listening to the interviews multiple times and re-reading the transcriptions to understand broad themes about what was being discussed was employed.

The transcriptions were coded through bottom up, open coding, rather than coming up with a list of $a$ priori codes. By reading each transcript multiple times after the initial coding and listening to the interviews on an $\mathrm{mp} 3$ player in a variety of settings over the course of several months, I was able to take an iterative look at my data, allowing for greater refinement and identification of codes that emerged from the data. I shared and solicited comments on my initial code structure with other students in my Atlas.ti course and with other graduate students, including two at other universities who had expertise in co-ops and the social economy. 
The repeated revisiting of the data encourages abductive reasoning. Described as different from both deductive and inductive reasoning in Interpretive Research Design: Concepts and Processes (Schwartz-Shea and Yanow 2012), - abductive reasoning directs the researcher via surprising puzzles and anomalies toward new possible explanations. Abductive reasoning is disinterested both in ascertaining "general principles or propositions from specific events" and in "general laws deduced from testing hypotheses against data" (ibid, 28). Abductive research does not flow in a step-wise linear fashion, but in a circular-spiraling pattern.

As such, the questions that I used to go from the coding step to the framing had me constantly return to the data. I found the questions posed by the University of Vermont "Sociology of News" course syllabus on frame analysis to be helpful for understanding the underlying assumptions in frames.

A. What do these frames imply is important? What do they take for granted?

B. What do these frames exclude from discussion?

C. What worldviews are these frames reinforcing?

D. Would different frames lead to a better society? [In the case of this research, society could be read as co-op or even food system.]

(adapted from How to do a frame analysis of news media 2009)

Thus, by mentally answering these questions, either directly or by constructing some textual narrative around them, I was able to go from coding to articulating the framing used in the case studies.

\subsection{8: Post-fieldwork developments}

Finally, I offer a note about post-fieldwork developments included toward the end of each case study. Though the original fieldwork, site visits, and follow-up communications were conducted between autumn 2013 and spring 2014, I have included some information gleaned in the late summer and autumn of 2016. Through social media, online information, and informal contact with established respondents, I learned of some significant changes at both La Montañita and Mountain View Market, with the developments at La Montañita still in play and ongoing. Though it was beyond the scope of this research to investigate these issues though further analysis or corroborating interviews, I have briefly described 
these developments, because of their implications on the framing of local food that I encountered at the time of fieldwork.

In the case of La Montañita, I proceed with particular caution, because the concerns related to this matter are very contentious: difficulties in managementlabor relations, perceptions of alleged financial misconduct, and questions about democratic control, transparency, and the Co-op's commitment to environmental sustainability. I have attempted to briefly outline the situation's undisputed facts and then to indicate the perceptions of the problems from the main sides involved. In taking this approach, however, I am reliant upon the very polarized views of different parties, including website information and statements that may be inflammatory or incorrect. They do offer a glimpse of the issues at hand, but they necessarily fall short of offering the "whole truth" of the situation.

In the case of Mountain View Market, though the situation was less volatile, there was much less information publicly available about the changes. This suggests there was also less member-owner engagement and communication. For instance, a significant change in personnel was mentioned in a blog post on the web site but not in the minutes of the Board meetings. A public comment on the blog post questioning the personnel change was met with a reply to email the board directly for further information. I followed up at this email address several times and received no response. Since there was scant related documentation available from Mountain View Market, I crafted a short description of changes at that co-op mainly based on brief anonymized email exchanges with extant respondents. 
-

axis

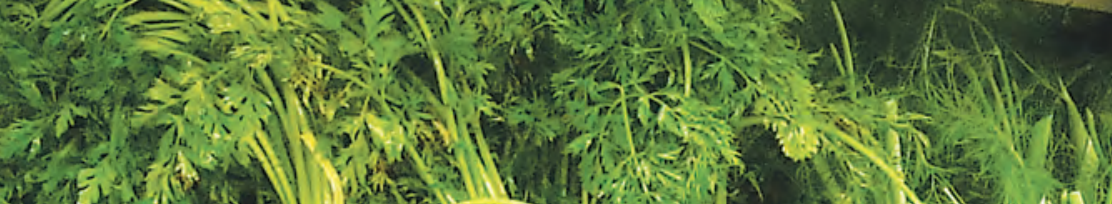

a $\left.x^{2}-1+4\right)$

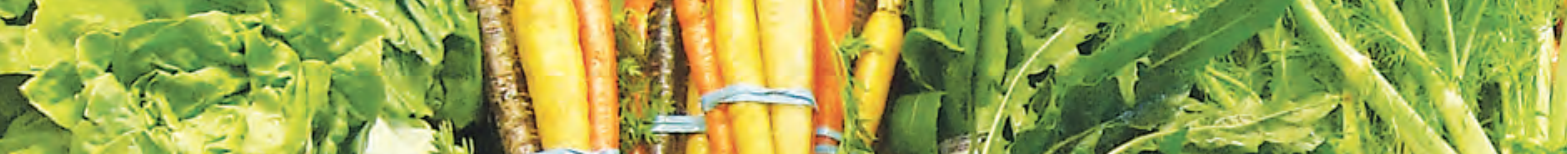

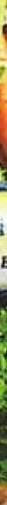

arditsen

mets

sites

Hivis $(x)=$

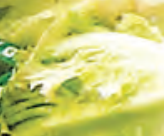

1.t.

(1) $x$

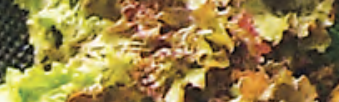

20

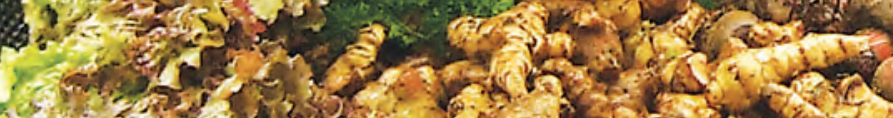

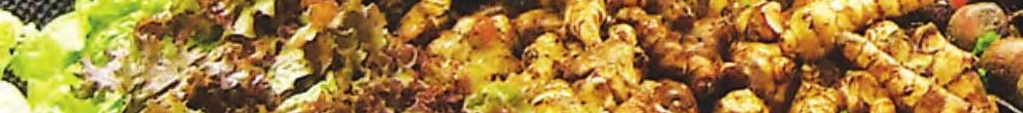

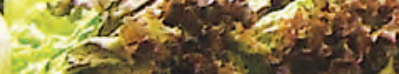
tom 112

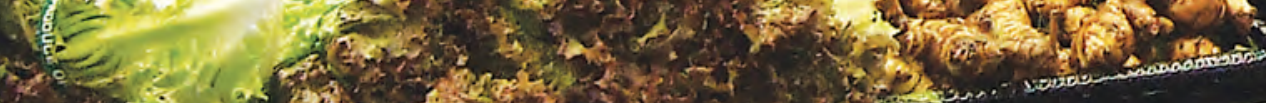
5.t.

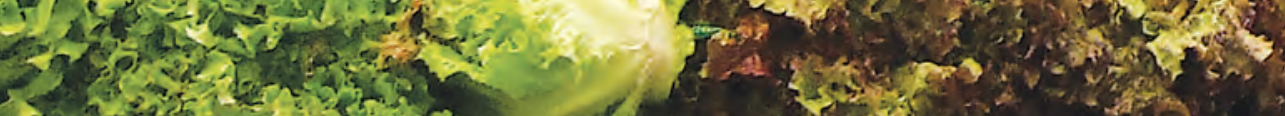

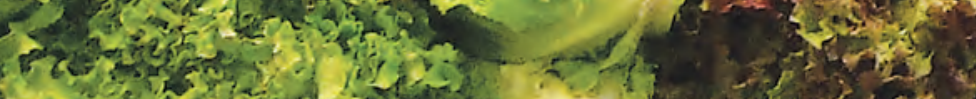

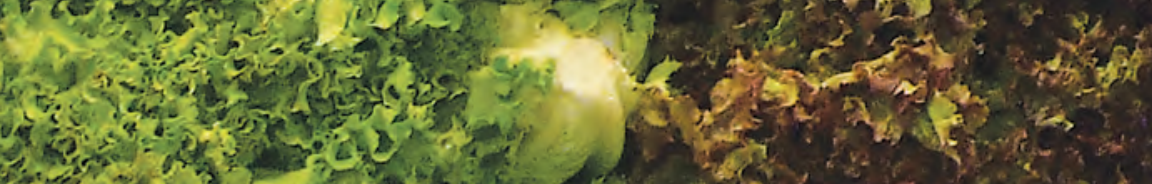

norit $=$ 
This chapter introduces the main case study, La Montañita Food Co-op located in the northern part of the state in several locations. I describe the case and its framing (and then reframing) of local food coincident with a strategic plan. This is followed by discussion of important post-fieldwork developments at the Co-op and the manifestations of embeddedness and diverse economies there.

\section{Chapter 4: Case Study of La Montañita Food Co-op}

La Montañita presents an interesting case as a successful co-operative that has a large bulk of its retail sales in local and regional products. This includes fresh produce, meat and dairy products, shelf-stable value-added items (such as prepared sauces and baked goods), and health and personal care (such as soaps and cosmetics). Currently, local or regional products make up about $20 \%$ of La Montañita's sales. La Montañita uses a definition of local being located within 300 miles of Albuquerque. This allows local to encompass the entire state of New Mexico. While this distance is large, it must be seen in the context that food in the US travels about 1,500 miles or more from its original source of production to the end customer. ${ }^{44}$

\section{Research Questions}

1) How do cooperatives frame local food?

a. What do the staff at retail food co-ops talk about when they talk about local food?

b. What do the staff at retail food co-ops say about local food?

This question refers to the perceptions and experiences of the staff of the cooperatives. I did not seek individual and household-level customers' perceptions and experiences of local food, as provisioning of local food is undertaken by employees, not customers. As such, consumer perceptions of local were beyond the scope of this research.

2) What are the practices that retail food cooperatives use to engage in local food?

\footnotetext{
${ }^{44}$ The Leopold Center at lowa State University compiled several studies between 1969 and 1997 addressing distances travelled by produce items in a number of states. Those distances ranged between 1,300 and 2,200 miles. http://lib.dr.iastate.edu/cgi/viewcontent.cgi?article=1002\&context=leopold_pubspapers
} 
Though listed as separate questions, these are in fact taken together in this chapter. This is because a central understanding of the use of framing is that an actor's definition of a problem or phenomenon shapes the actions taken to address that problem or phenomenon (Fenton and Langley 2011). As such, this chapter describes the articulation of La Montañita as an instrument for local food provisioning, both in the framing of local food and by the practices the Co-op has subsequently employed to engage with local food. Following an overview of the Co-op's locations, trading environment, and internal organization, I discuss the vision presented in the Co-op's Strategic Plan that was approved by its Board in 2006. This vision offered both a framing of local food and a specific plan of work that would be utilized to further this vision. The "original framing" section (4.2) examines the language of a single document, La Montañita's Long Term Strategic Plan, and incorporates some clarification comments offered in an interview of the General Manager who was in post at the time of the plan's approval. Where there are plain quotes in section 4.2, they come from the document; where there are italicized quotes, they come from the interview.

After this, I offer a reimagining of La Montañita's framing of local food, based on participant observation and several interviews with staff members of the Co-op approximately seven years after the adoption of the Strategic Plan. The final sections of this chapter examine specific frames and meanings regarding local food, the practices developed in the intervening seven years to advance the plan of work, and the post-fieldwork developments. Finally, I offer some reflections on this case study and findings about embeddedness and diverse economies that will be analyzed later in the discussion chapter.

\section{1: Overview}

La Montañita Co-op Food Market is a consumer-owned co-operative in the natural and organic foods sector with 6 retail locations and a distribution center headquartered in Albuquerque, New Mexico. La Montañita began in 1976 as co-operative owned by 300 households and was managed largely as a volunteer collective for three years before transitioning to employing paid staff. By 2004, there were 10,000 owners, and La Montañita had sales exceeding \$12 million. In 2013, La Montañita Co-op was owned by over 14,000 households and had annual sales in excess of $\$ 32$ million, with over $\$ 973,000$ in net revenue. La Montañita's growth strategy, its focus on local food provisioning, and its collaborations with small and 
medium-sized producers offer an interesting case study of one retail cooperative's engagement with local food.

\subsection{1: Locations}

Nob Hill

In 1986, after 10 years of operation at its initial location at Central Avenue (formerly Route 66) and Girard Boulevard in Albuquerque, La Montañita moved a half-mile from that first 1,000 square foot property to what became its flagship store. That new store, measuring 10,000 square feet and located in an area of Albuquerque called Nob Hill, is an anchor tenant in the Nob Hill Shopping Center. The Nob Hill Shopping Center is on the National Register of Historic Places because of its significance as the state's first drive-in shopping center ${ }^{45}$ and its location on the historic Route 66. (Route 66, the first paved road crossing the state of New Mexico, also served as the main road for westward travel to California during the Great Depression.) Today, the Nob Hill area is both a tourist draw and a trendy, sought-after neighborhood with an eclectic mix of businesses (many independent and locally-owned). The Nob Hill store was a training ground for several of La Montañita's current senior administrative and professional staff whom I encountered in my fieldwork, as many started their careers with La Montañita there.

Valley (Rio Grande)

La Montañita expanded to a second location in 1999 with the opening of the Valley store (also measuring 10,000 square feet) on Rio Grande Boulevard in a small shopping center. This location is more residential and has fewer supermarket and retail food contenders than what is available in the Nob Hill area. The Valley store's produce department has won several produce management awards and has built strong working relationships with local growers.

Santa Fe and Gallup

In 2006, La Montañita opened its first two stores outside of Albuquerque - a 10,000 square foot space (since expanded) in Santa Fe (65 miles northeast of Albuquerque) and a 1,500 square foot space in Gallup (140 miles west of Albuquerque). These two stores represent very different demographic areas, with Santa Fe home to a thriving economic and cultural community, and where many workers of the nearby

\footnotetext{
${ }^{45}$ According to its citation on the National Register of the National Park Service, that shopping model represented "a shift in the built form away from the pedestrian realm toward accommodating the increasingly prominent automobile." http://www.nps.gov/nr/travel/route66/nob_hill_shopping_center_albuquerque.html.
} 
Los Alamos National Laboratory and Sandia National Laboratories reside. By contrast Gallup has suffered from low economic investment and the effects of mine closures. Gallup is also in the heart of Native American tribal lands of the Zuni, Hopi, and Navajo nations, which have historically been impoverished and prone to social ills related to inequality and deprivation. According to 2013 data, the percentage of people living below the poverty line was approximately $18 \%$ in Santa Fe, and in Gallup it was over $41 \%{ }^{46}$

Despite their differences, each of the Gallup and Santa Fe stores was opened after conversions of independent grocery stores in dire straits. The Gallup location essentially took over the failed effort of the Wild Sage Co-op, which had been struggling for some years with a burnt-out all-volunteer board and staff. La Montañita anticipated it would take years to recuperate their investment costs in Gallup. According to a former staff member, they essentially viewed their mission there as one of service to the co-op community and to provide local residents with a source for healthy food. The Santa Fe store opened in the location of an independent natural and organic grocery shop called the Marketplace that had operated for over twenty years but whose owner wanted to retire. The Marketplace was succumbing to increasing competition from larger corporate food retailers moving into Santa Fe in the 1990s. The market for natural and organic food in Santa Fe became saturated with five such shops extant within 1.5 miles of the Marketplace. Since La Montañita's acquisitions, both store locations have done well, with the Santa Fe store consistently grossing the highest revenue of all La Montañita Co-op locations and the Gallup store exceeding expectations for the timeframe for breaking even.

\section{UNM Grab \& Go}

In 2011, La Montañita opened its first convenience store format shop on the campus of the University of New Mexico (UNM). The Grab \& Go is 800 square feet of retail space housed within the UNM campus store and focused on providing healthier portable, convenience meals. The idea for the Grab \& Go sprang from a desire by students in the University's Sustainability Studies Program (SSP) to have more sustainable food choices on campus. They took this idea to the UNM administration in early 2010, which directed them to consult with national and regional corporate

\footnotetext{
${ }^{46}$ From data available through a US Census tool, which requires entering information values for a desired location http://factfinder.census.gov/faces/tableservices/jsf/pages/productview.xhtml?pid=ACS_13_5YR_ S1701\&prodType=table
} 
grocery chains. Because of their understanding of alternative economics and food sustainability, the SSP students resisted the idea of these chains as the solution. Instead, the students began organizing themselves to open a student-run co-op on campus.

After it became clear in the following months that the students had neither the time nor expertise to run the co-op, they approached La Montañita in hopes they would take over (Seydel 2011). La Montañita had already been connected to the SSP via regular guest lectures on food sustainability from La Montañita's Membership and Community Outreach Coordinator. This Coordinator had also provided advice and support to the students when they were planning to run the co-op themselves. La Montañita agreed to take on the project, and the Grab \& Go has been very successful.

The Grab \& Go's product mix includes breakfast sandwiches and muffins, salads, burritos, and prepared meals, cold and hot beverages, and snack items. As the Grab \& Go has no space for product storage or preparation, deliveries are made from the nearby Nob Hill store several times each day. This required La Montañita to become more innovative and flexible in their supplying

Map 4: La Montañita locations in Albuquerque, NM

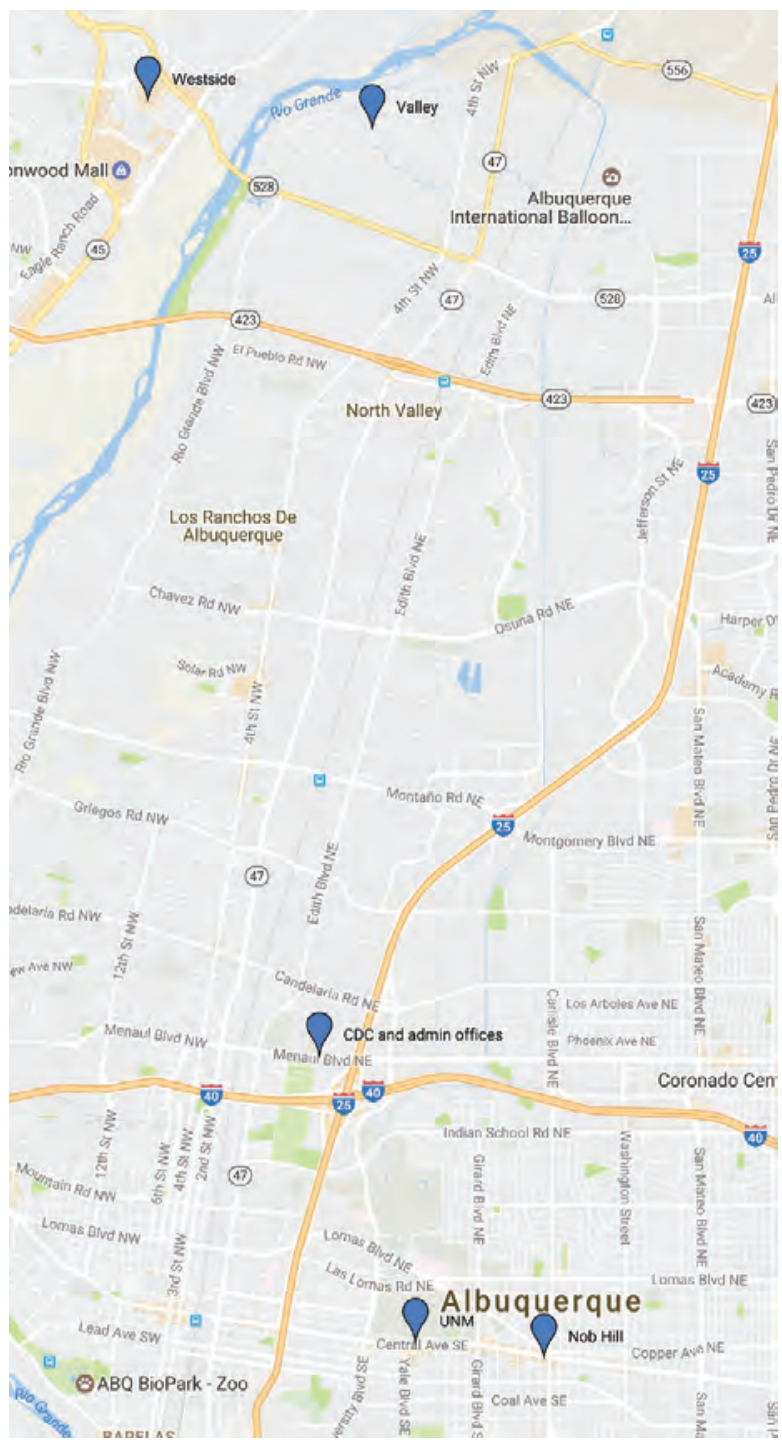

Source: Google Maps, elaborated 
approach, and they have added to their offerings by placing a daily-serviced, fresh and prepared foods vending machine on the opposite side of campus from the Grab \& Go location.

\section{Westside}

The fourth and newest retail location in Albuquerque, the Westside store, was opened in autumn 2013 approximately halfway through the time of my fieldwork. Westside is 6300 square feet of retail space in an area of very dense retail development. This area includes many restaurants, convenience food retail options, and three large grocery chain stores (including a Wal-Mart Supercenter and a Sprouts - a regional supermarket chain in the natural and organic sector). This may be La Montañita's most competitive market in Albuquerque, as these competitors are all within $3 / 4$ of a mile of one another. At Westside, there is a significant focus on convenience food options, including a 26-foot-long salad bar, a deli and hot prepared foods counter, and a coffee bar.

The Co-op Distribution Center (CDC)

In addition to its six retail locations in Albuquerque, Santa Fe, and Gallup, La Montañita launched a wholesale distribution operation, also based in Albuquerque, in 2006. The Co-op Distribution Center (CDC) was established as a cornerstone of La Montañita's long-term vision for local and regional food and began as a warehouse and aggregation point for produce from local farms. Though the original vision changed to include less fresh produce, it has remained part of La Montañita's vision for continued relevance and profitability in the face of increasing competition from large corporate chain supermarkets. The $C D C$, which shares a building with the Co-op's support and administration offices, will be discussed in later sections of this thesis.

\subsection{2: La Montañita, organizationally speaking}

\section{Staff}

La Montañita Co-op employs nearly 300 full and part-time staff, paying a "living wage" to all employees and providing an employee benefits package. The living wage concept is part of a national economic justice movement in the US that recognizes that the federally mandated minimum hourly wage is insufficient for people to live on satisfactorily. As such, individual states and localities at different levels of government can set an hourly wage amount meant to keep people (or 
help people) out of poverty. The living wage compensation model was introduced at La Montañita after a failed unionization vote in 2003. At the time of fieldwork, La Montañita paid an average minimum wage of $\$ 10.22 /$ hour for the lowest employee grade throughout their stores. This is contrasted to the federal minimum wage of $\$ 7.25 /$ hour and the New Mexico state minimum wage of $\$ 7.50 /$ hour. The average wage paid by La Montañita's Santa Fe location is higher than their other locations, because the minimum wage mandated by the city of Santa Fe is $\$ 10.51 /$ hour (again, at the time of fieldwork). The Co-op reconsiders its hourly wage amount each January. Notably, nearly all of La Montañita's staff is on an hourly wage; just 5 senior staff members (including the General Manager) have salaried positions at the time of fieldwork.

\section{Membership and Governance}

One does not have to be a member to shop at La Montañita. Membership is encouraged, however, through various means. There is prominent store signage about membership, and cashiers may also ask customers whether they are members at the checkout tills. Information is available at membership information desks in each store. Membership costs per household are $\$ 15$ for an annual membership or \$200 for a "lifetime" membership. A household can consist of up to 3 adults at one address. In addition to patronage dividends, shopping discounts, and special programs available only to members, much emphasis is placed on the ability of members to participate in the governance of La Montañita and to influence how the Co-op is active in its local community.

La Montañita has a 9-person board of directors, each of whom serves a 3-year term. At the time of fieldwork, the Co-op had no term limits. Co-op members who have been members for at least 4 months are able to stand for elections, held each November during a 2-week period of voting. La Montañita switched to an online balloting system with notification by email in 2012, but paper ballots are also available. Board meetings occur monthly and are open to the public. The annual member meeting (part celebratory gathering and part annual report presentation) is held each October.

The Co-op uses the Carver Policy Governance model, which articulates the board's role in creating organizational goals and policies, while delegating the execution of said goals to the General Manager with minimal interference. As one board member 
said, "It allows us to get out of the way to let Terry [the General Manager at the time of fieldwork] just do his job." The main organizational goals or mission statement of the Co-op are conveyed in a document called the ENDS policy. This term is common parlance in the organizations that use the Carver Policy Governance model, but the actual ENDS policy is always specific to the individual organization. In the case of La Montañita, a new ENDS policy was adopted with the following language in September 2013: A co-operative community built on beneficial relationships based in healthy food, sound environmental practices, and a strong local economy with results that justify the resources used.

Volunteer and Community Engagement

La Montañita engages in many ways with the local community (with individual shoppers and institutions/groups) and has been working on outreach since its inception. Their most successful venture in terms of attendance is in hosting the state's largest Earth Day festival, drawing approximately 20,000 attendees each year. Other efforts include involvement in local fairs, participation in policy councils and activist groups, financing charitable giving programs, organizing special standing projects, and administering a volunteer program. Some examples are below:

- The Co-op runs an extensive volunteer program that benefits them and many community members and institutions. Though La Montañita had employed paid staff by the 1990s, a change in US labor laws prohibited food co-ops from using volunteer labor in the ways that they had for years. Typically, co-ops would allow members to do various basic jobs needed to run the co-op in exchange for a shopping discount. Co-ops such as La Montañita could no longer use volunteers to do such tasks as stocking shelves, bagging dried fruit, etc., without also providing workers' compensation insurance and benefits equivalent to the minimum wage.

In order to allow members to do volunteer work that they could no longer do at La Montañita, a program was developed to match volunteers with any of approximately 60 non-profit organizations around the state. One hour of voluntary work at an organization would be worth a voucher for an $18 \%$ discount on the total bill for a shopping trip at La Montañita. This allowed more than 250 volunteers to do community development outreach projects at homeless shelters, peace organizations, and economic justice and 
development organizations, etc., representing La Montañita. Volunteers could also work in the public school system, for instance, by volunteering in their child's school.

- Many grocery stores offer a small credit (such as 5 or 10 cents) when shoppers bring reusable bags to carry their groceries rather than taking new plastic or paper bags. Rather than paying that credit to the customer, La Montañita will instead donate that amount to a designated community organization that changes each month.

- La Montañita is represented on many local policy groups related to food, farming, and the environment through sponsorships and collaborations, guest speaking, and other types of participation. These include the Organic Consumers Association, the New Mexico Strategic Leadership Institute, the Mid-Region Council of Governments' Agricultural Collaborative, the Agricultural Food Policy Council, New Mexico Farm-to-Table, the New Mexico Department of Agriculture Organic Program, and the Farmers' Union.

- La Montañita helps run a program to encourage rehabilitation, employment, and skill development for returned war veterans via an urban farming program called the Veteran Farmer Project (VFP). This collaboration between La Montañita and several organizations (including the New Mexico Department of Agriculture, the Veteran's Administration, Holistic Management International, and the Downtown Action Team) provides the initial training for veterans to start or work at sustainable agriculture businesses. The VFP grows produce at the Alvarado Urban Farm in Albuquerque to fill CSA boxes for low-income families year round and sells at a farmers' market once a week during the summer. 
Photo 1: Veteran Farmer Project space in Albuquerque

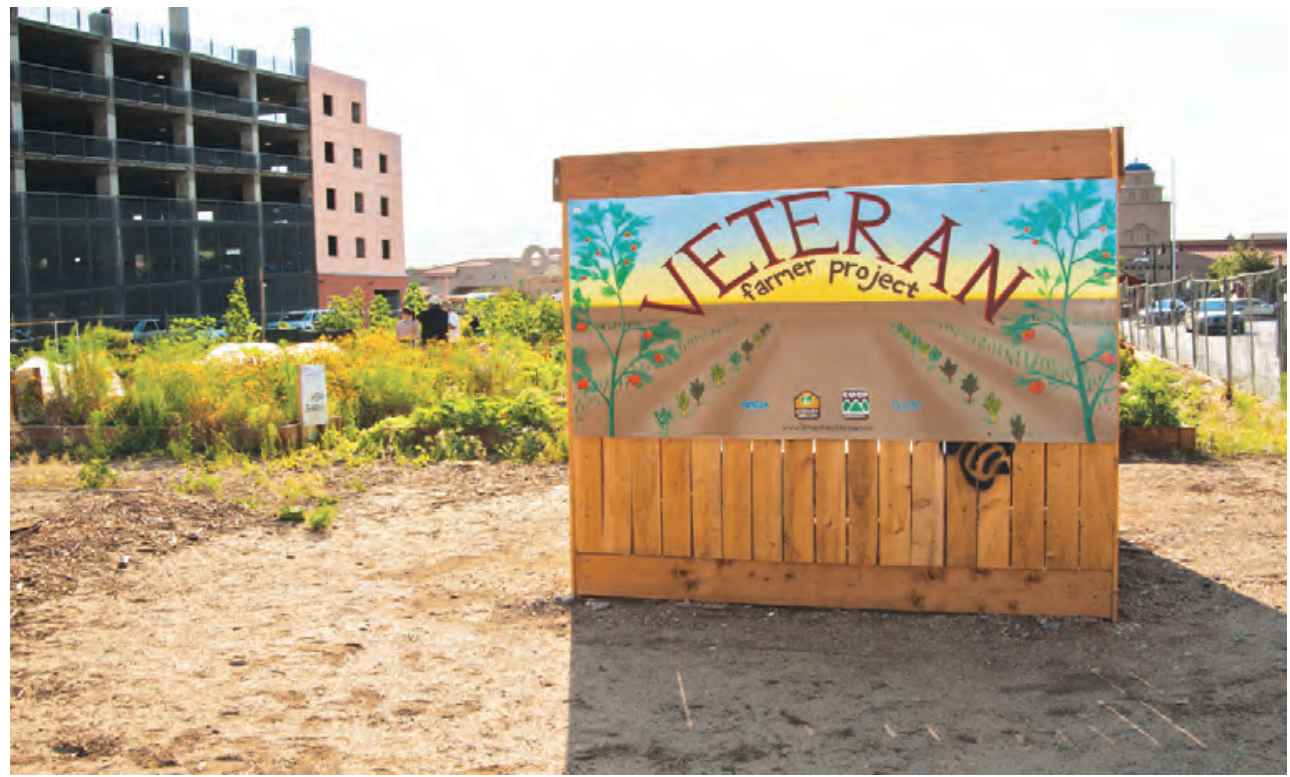

Source: https://www.flickr.com/photos/usdagov/9355668357 USDA photo by Bob Nichols - (CC) license 2.0

\section{2: Original framing of local sourcing as a strategic vision}

In July 2006, a management team of eleven people presented the Long Term Strategic Plan to the Board of La Montañita Co-op. This plan offered a vision for the growth and development of the Co-op over the next few decades based on an understanding that the Co-op needed to engage in a concerted effort to develop its niche as a local food purveyor and as a crucial element in the sustainable food economy of New Mexico. The natural and organic market had become saturated with many regional and national supermarkets also carrying the sorts of products that La Montañita specialized in. The management team saw this increasing competition as an impetus to examine how the Co-op could remain relevant and do more than just survive.

"These new competitors will continue to drive down profit margins on our products and consume an increasing share of manufacturer promotion dollars. Lower prices and fewer promotion dollars will make it very difficult for us to remain competitive and service our rising cost of doing business. The dramatic increase in consumer demand for natural and organic products is creating new economies of scale that favor the largest retailers" (Pugh et al. 2006, 2). 
Over the years of its existence, La Montañita's customer survey research repeatedly indicated that Co-op's unique selling point was its offering of locally produced goods - routinely listed as either the primary or secondary reason for members to shop at La Montañita. Thus, the crux of La Montañita's Long Term Strategic Plan highlighted the importance ensuring continued access to local products. By developing and maintaining a strong local market and supply base, especially in light of the corporatization of natural and organic food by big national chains, La Montañita was acting in its own self-interest, as well as helping its suppliers. What highlighted this was the closure of several longstanding local businesses that La Montañita depended on, and serious efforts were taken to identify and understand more thoroughly the circumstances of the local suppliers to the Co-op.

"We lost our bagel producer... That was a catalyst to me. It was the best bagel in town... This was a premium product. Customers were really upset when they didn't have it anymore. Even though we were able to get another local bagel, it wasn't the same quality. It was a big deal. That's what got me started looking into this..." - GM 1

The strategy developed and broadly outlined in the strategic plan had the creation of a regional food shed at its centerpiece. The plan specifically identified four areas of work, all of which would require significant progress to meet the short, medium, and long-term ambitions of the management team. Those areas - distribution, market expansion, producer coordination and support, and local brand development (Pugh et al. 2006) - were decided through extensive visioning exercises and research (including input from business students at the University of New Mexico). The plan discussed several local and regional food projects which were struggling or had failed, but which lacked an element that La Montañita had and deemed vital: solid retailing experience.

"Our position as a retailer provides us the control and leverage that other efforts have lacked... Our current success in expanding local production and growing our cooperative has created a strong foundation that we can build upon to transform the food system in our region" (Pugh et al. 2006, 2).

By focusing on retailing local products, La Montañita's long-term plan was no less than to become the cornerstone of a sustainable food system in New Mexico. This expertise and the relationships that the Co-op had cultivated in expanding its own 
operation and sales of local food were to be the unique differences between it and other regional food projects.

Because of La Montañita's long history of being "the farmer's friend" (e.g., paying farmers upon delivery of products or within 30 days, instead of the 90-day terms common with other retailers), the Co-op found itself well-placed to use the networks and experience it has had - as both buyer and a seller - to create a program of initiatives to build a more sustainable local food system. Various employees of the Co-op spoke of the program by different names - mainly the Food Shed Initiative, the Food Hub, or the Co-op Trade Initiative. It can be understood, however, as collection of approaches to address the aforementioned four key areas discussed in the plan.

\section{Distribution}

Travel distances and the sparse density of population in New Mexico make distribution a costly and time consuming affair at the best of times. Notably, the Strategic Plan was created at a time of the highest per gallon gasoline prices that the US had seen in 15 years, ${ }^{47}$ with prices that would continue to rise for another 12 months. Through a survey of its local suppliers, La Montañita was assured that efforts to assist those who did not have the time or ability to distribute their goods would benefit the Co-op's ability to bring more local food to market. The longterm strategy required that the Co-op make a major investment in expanding its operations to include distribution, leading La Montañita to acquire a warehouse facility and trucks to transport products.

\section{Market Expansion}

Increased local production would require wholesale and retail markets into which products could be funneled. "A sustainable food system requires both regional production and a market for that production. Local production expansion cannot be sustained without market expansion" (Pugh et al. 2006, 4). The targets suggested in the plan for market expansion were a combination of new, additional La Montañita storefronts and other independent food retailers, rather than multi-store national chains. In order to facilitate value chains, these storefronts should be in close proximity to the points of production.

\footnotetext{
${ }^{47}$ From data available through the US Energy Information Administration http://www.eia.gov/dnav/pet/hist/ LeafHandler.ashx?f=W\&n=PET\&s=EMM_EPMR_PTE_NUS_DPG
} 


\section{Producer Coordination and Support}

The Strategic Plan hypothesized that this area might be the most difficult one in which to make progress (Pugh et al. 2006, 4), as La Montañita's own prior work with suppliers showed it was difficult to have a good mix of local commodities coming onto the market. The Co-op had been working on coordination and support through a third-party organization headed by a Co-op staffer, but this was proving an unsuccessful arrangement. The plan aspired to create two new separate positions at La Montañita: one for coordinating local food products and one for supporting new and extant local producers.

\section{Local Brand Development}

The Co-op recognized the need for educating consumers on the value and attendant benefits of buying locally produced products, rather than ones from large-scale industrial production. As it remained with the customer to choose local products despite the often-higher prices, La Montañita identified specific points of emphasis to highlight the long-term value to the community that local food would bring. To wit: "We will emphasize both the fresh advantage of local products and the fairness to all parts of the system of paying the true cost of local production and distribution" (Pugh et al. 2006, 4).

\section{Other Goals}

In addition to these general areas of work, the plan presented some specific goals regarding increasing the number of La Montañita storefronts (from two stores at the time of the plan's conception to eight stores within ten years). There was also the ambition to integrate up to 30 independent retail, restaurant, and institutional buyers into the Co-op's distribution system within the first decade as well. These additional retail outlets were envisaged to increase the volume of local food being aggregated and distributed by La Montañita. Finally, but critically, the plan foresaw some personnel and staffing requirements to manage the coordination of the products and producers that would come into the distribution facility and flow to the outlets that would handle the increased volume. In short, this envisaged program would have distribution processes at its core. 
Photo 2: La Montañita's oldest (Nob Hill) and newest (Westside) locations
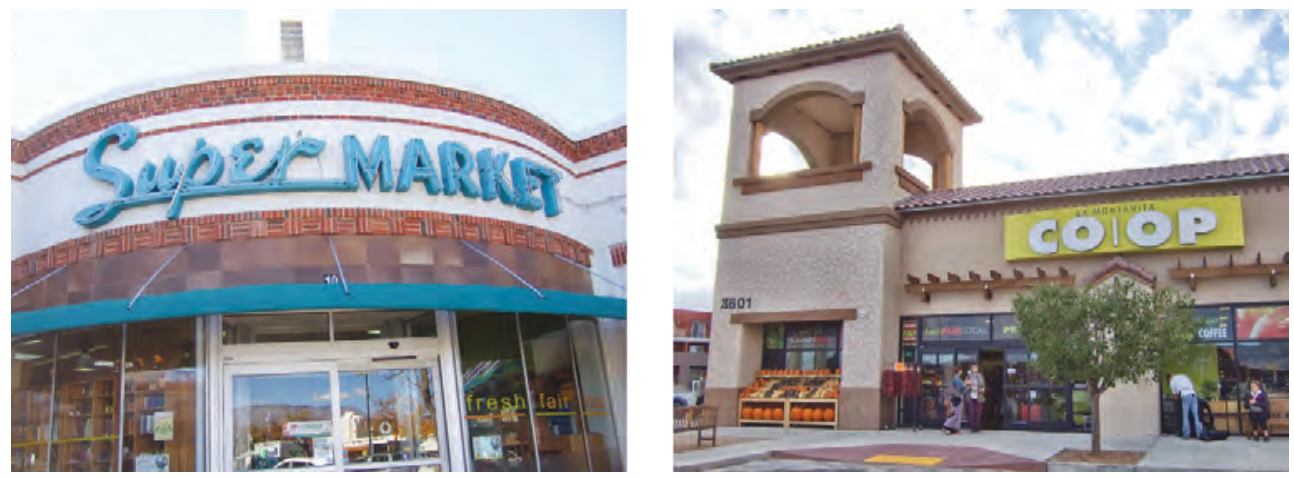

Interim Results

Though the Co-op Distribution Center (CDC) did indeed come into being in 2006, the ambition of the plan underestimated some entrenched organizational aspects of the Co-op itself. La Montañita made significant progress in reaching some goals set out by its long-term strategy, but the actualities of how the Co-op's departments operated required an important reconsideration of what could be accomplished and when. While the long-term strategy was very ambitious, some core features quickly proved less than successful or unworkable, or were otherwise not followed. Although the subsequent points may be the result of some interim re-strategizing, they at least may been seen as deviations from the original Strategic Plan.

- Far less local produce than envisaged was sold and distributed by the CDC to the storefronts. The CDC was first able to break even in the fiscal year ending in August 2013.

- The percentage of sales from local food, predicted to be nearing $40 \% 10$ years into the plan, was estimated to be actually at $20-30 \%$, though the numbers provided were very general estimates. When local sales data was available, it was often not well integrated or used, despite the plan calling for this to happen.

- Though some sales data is obtained at the point of sale in the storefronts, there seemed to be less systematic monitoring of local product sales in the aggregate than called for in the plan. Some particular items for which La Montañita is the sole distributor may have been more rigorously tracked however. 
- Market expansion has occurred, though purchases by La Montañita storefronts continue to make up half of that, and significant public procurement seems not to have been pursued.

- No local produce manager or staff person was hired to coordinate local provision between producers, store departments, and transportation operations.

\section{3: Ongoing (re)framing of La Montañita's engagement with local food}

La Montañita Co-op is still very invested in local food provisioning as its unique selling point, despite the slower-than-anticipated pace of progress on its original Long Term Strategic Plan. Indeed, the number of local suppliers' products being sold and distributed via the CDC has grown, so producer interest also remains high. La Montañita however, scaled back some targets for the CDC when it became clear that it would not move as much local product, especially produce, through its warehouses and has pursued other avenues to expand the market for local food. This reality highlighted the need for me to understand more thoroughly how La Montañita is framing local food and, by extension, what practices it actually employs (with respect to local food). This examination was to see beyond the robust business potential described in its Long Term Strategic Plan.

\subsection{1: Conducting interviews}

As La Montañita Co-op is an organization with nearly 300 employees at 6 retail locations and a distribution warehouse, what quickly emerged was the understanding that the informants had various interpretations of what their roles and functions were in the context of local food provisioning and of its meaning to the Co-op. Over the course of my fieldwork with La Montañita Food Co-op, I conducted interviews with board members, management, store and warehouse staff, and suppliers to explore aspects of the Co-op's operations, particularly with respect to initiatives to engage with local food provisioning. The interviews were conducted in a variety of settings, including individual and shared offices, on the shop floor, en route to and during the course of community events, and in private homes and local businesses. This allowed me to see a broad expression of La Montañita's work with local food and food suppliers and impressed upon me the complexity of the Co-op's engagement with local food. The following section describes the primary informants at La Montañita and their current (and often prior) roles at the Co-op. This offers 
some context to how they frame local food and, sometimes, the evolution in their thinking as La Montañita's circumstances have changed over time.

\subsection{2: Primary informants}

The General Manager (GM) of La Montañita is responsible for the overall management of La Montañita's retail and distribution divisions and reports to the Board of Directors. This person is responsible for a great deal of strategic planning and visioning regarding the growth and development of the Co-op, as well as its financial profitability. I interviewed the GM in post during my field research (but who is no longer with La Montañita) and the GM in post during the conception and the first two years of La Montañita's Food Shed Initiative to increase access to local food. As sales of local food increased under each GM, the mechanisms for incorporating local food into La Montañita's practices have evolved and were shaped differently between their tenures. Their comments are indicated by GM1 for the first post holder who helped create the Long Term Strategic Plan under which La Montañita began expanding its local food offerings. The comments from GM2 are those of the post holder in office during my fieldwork.

I interviewed the two members of the Membership and Outreach department who were responsible for a myriad of projects around membership cultivation and stewardship, community engagement, education, and volunteerism. This included board elections and membership meetings, the Veteran Farmer Project, La Montañita's extensive volunteer program, the monthly newsletter (done in collaboration with the Marketing department), and the annual Earth Day Festival in addition to many one-off projects. (All of these projects had a strong marketing aspect to them, so there was significant contact between the Marketing staff and the Membership and Outreach staff.) The head coordinator of Membership and Outreach (whose comments are noted as $\mathrm{MC}$ ), had worked in various capacities with the Co-op for nearly 30 years and was also very involved in the La Montañita Fund for community investment available to local producers.

I interviewed three staff members within the CDC: the warehouse manager (CDCWM), the purchaser (CDC-P), and the sales representative (CDC-SR). The warehouse manager, who started in that position from the CDC's inception, had worked at La Montañita in various roles for over two decades, including as a produce manager and a store manager. The warehouse manager, in addition to being the head of 
warehouse operations was in charge of the CDC's local beef program, its local cheese program, and the purchasing of any produce that would be ordered through the CDC. The sales representative, who had been with the CDC for four years, was charged with expanding the distribution operation to food service and restaurant industry customers. The sales representative was responsible for recruiting new customers and managing ongoing accounts that mainly consisted of full-service restaurants in and around Santa Fe and Albuquerque. The purchaser had worked in several storefronts over the course of seven years, finally serving as a meat and cheese manager before moving to the CDC. The purchaser was responsible for ordering all the products the CDC sold that did not fall in the purview of the warehouse manager. This included the shelf-stable grocery orders from UNFI (United Natural Foods, Inc.) - the leading distributor of natural and organic food products in the US - with whom the Co-op has a buying contract ${ }^{48}$ via its membership in National Cooperative Grocers (NCG), formerly the National Cooperative Grocers Association (NCGA).

I interviewed the business enterprise development coordinator (BEDC) whose remit was to provide advice and the perspective of the Co-op to local producers. A primary aim of this service is to help bolster a regional food system by addressing specific food sector challenges that often destabilized small producers. This requires assessments and site visits to producers. This position also provides distribution support and market expansion services to the local businesses for which La Montañita is the contracted distributor. Though the business enterprise development advice is also available to any department of La Montañita's storefronts to help them make assessments and strategize when taking on local vendors' products, departmental uptake has been scant. The CDC has requested most of the work demanded of this position.

I interviewed a produce manager (PM) at one of the La Montañita storefronts who had worked for about four years in that post in Albuquerque but who began as a produce clerk in another storefront. The produce departments at the Co-op have a great deal of independence, and each one has been at liberty to create

\footnotetext{
${ }^{48}$ NCG is a business services co-op with 143 members (including La Montañita and Mountain View Market) in the natural and organic foods retail sector. A main component of their work is leveraging purchasing power and operational and marketing resources for its members. This includes the creation of a buying agreement with UNFI that allows co-ops agreed-upon competitive pricing on a large number of grocery items, enabling NCG members to be viable in the market place. NCG members participating in the contract receive specific discounts for volumes purchased and agree to make UNFI its primary distributor for certain items.
} 
working relationships with farmers at will. This produce manager and another in Santa Fe with whom I had email contact had extensive interactions with farmers. They separately organized training materials for farmers wishing to sell to the Co-op to familiarize them with expectations and good business practices. At the time of fieldwork, the produce managers had just scheduled some conference calls amongst all the La Montañita produce departments to coordinate the purchase of produce from Veritable Vegetable, La Montañita's main produce supplier based in California. ${ }^{49}$ This sort of coordination had not been done before and was indicative of produce departmental autonomy. There had been a lot of turnover in the produce departments in the years prior to my fieldwork, and most produce buyers at the storefronts had been with the Co-op fewer than two years.

\section{4: Framing the subject}

Taken together, these aforementioned informants all have job responsibilities that fall within the four areas of work espoused by the original long-term plan: distribution, market expansion, producer coordination and support, and local brand development. When interviewees spoke of local food they typically characterized any or a combination of the following three phenomena:

- the food itself, anything from a raw agricultural product to a value-added processed product;

- the food producers - including farmers, growers, and value-added producers; or

- the La Montañita Co-op and its actions, history, and role in local food provisioning.

What follows is an overview of the interconnected understandings around local food framing and practices.

\subsection{1: Local food has a geographic meaning}

As discussed in Chapter 1, the geographical definitions of local vis-à-vis food production and distribution differ widely, depending on the context. La Montañita uses a radial distance of 300 miles (from its base in Albuquerque) to indicate the borders for local food production. Some NCG member co-ops also working on local

\footnotetext{
${ }^{49}$ Veritable Vegetable is an organic produce distributor based in San Francisco. They source mainly from smaller and family owned California-based farms and have a reputation as being an ethical firm with high standards of environmental stewardship in the produce wholesale world.
} 
Map 5: La Montañita's Food shed area

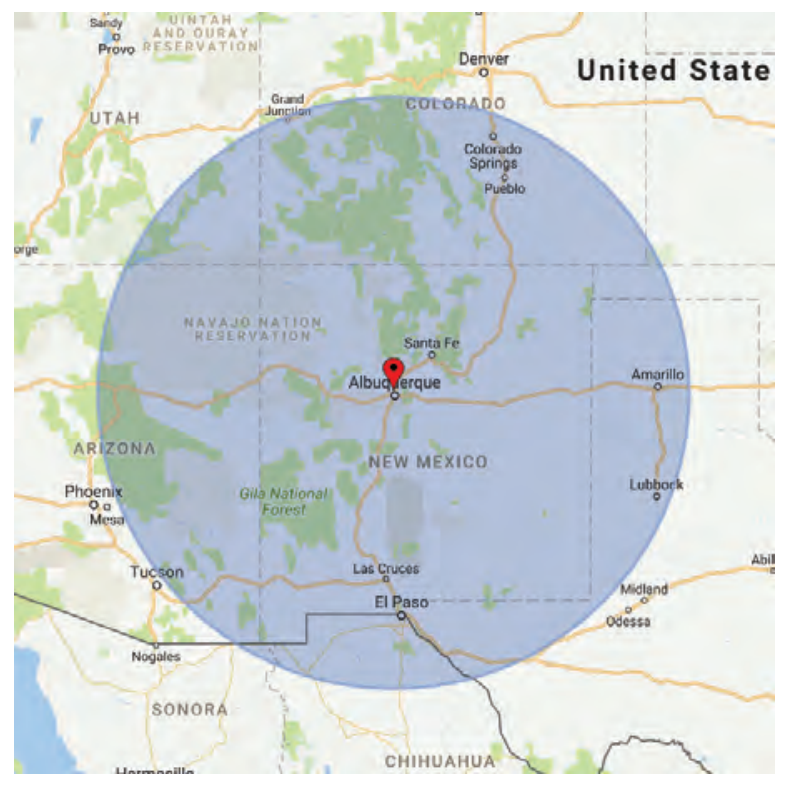

Source: Google Maps, elaborated

sourcing, but based in other states, have used a numerical metric (e.g., 50 miles for co-ops in Vermont) or a conceptual area (the entire state for co-ops in Minnesota). La Montañita's 300 miles is combination of both. It comes from the notion that the water needed for agriculture in the high desert of New Mexico where La Montañita is located comes from the Rio Grande River, which is located in a rift valley. The headwaters of the Rio Grande River are in the San Juan Mountains, extending approximately 60 miles into the southern Colorado border. "That's where most of our agriculture comes from, up and down that rift valley. So that's our watershed. And by extrapolation, because that's our watershed, that is our food shed here [in the high desert]... because that's where the food is produced... about a 300-mile radius around Albuquerque throughout the state..." - MC In this way, the Co-op allows the entire state of New Mexico, parts of southern Colorado, eastern Arizona, west Texas, and a small bit of Oklahoma to be included in the food shed. ${ }^{50}$

\subsection{2: Local food has an environmental meaning}

The vast majority of the fresh produce La Montañita sells is organically grown (upwards of $90 \%$, according to a senior member of the management team). At some storefronts (such as the Valley and Santa Fe locations), it is consistently higher than this. To do this, the Co-op uses four classifications of produce in labelling products for customer information: Organic, Local-Organic, Local, and Organic Local Food Shed. There are special signs and shelf labels that distinguish each of these

\footnotetext{
${ }^{50}$ Though technically the 300-mile radius also would include a small part of Mexico, but the Co-op seems to use a US-based geographical boundary as well. The Co-op does indeed get some produce from certified organic growers in Mexico, but they are not part of the food shed project.
} 
categories in the stores. Though there is presumably some "conventional" produce on offer at the Co-op, I saw nothing labelled as such at any of the four storefronts that I visited.

- Organic produce is certified organic through the USDA Organic program via an accredited organic certification body. This produce comes mainly from Veritable Vegetable.

- Local-Organic means the product has been USDAcertified organic and is local to the state of New Mexico.

- Local is a classification that the Co-op uses for New Mexico-grown products from uncertified producers that purport to produce food

Photo 3: Four types of La Montañita produce labels

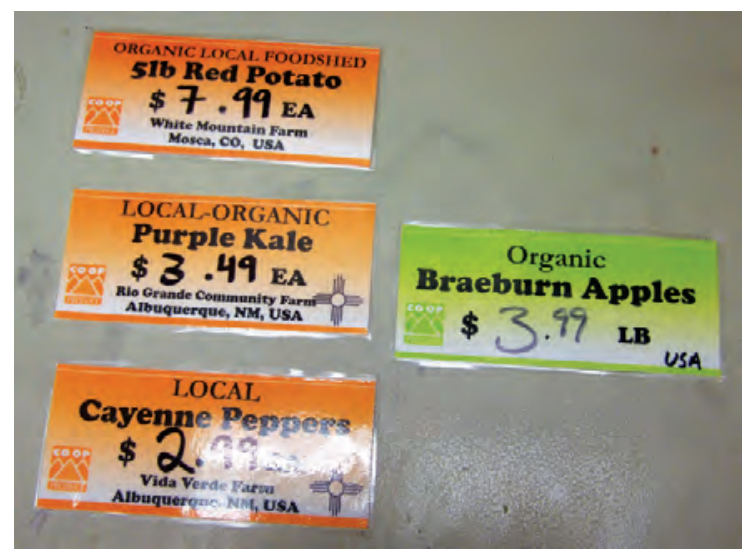
without petrochemical pesticides, herbicides, or fungicides. This was described as growing "clean" food in several interviews. While there is some degree of vetting of "local" producers at one time or another, there was no defined and ongoing inspection regimen being carried out by La Montañita for those producers who are not USDA-certified organic. As such, the Co-op cannot refer to those products as organic - whatever their growing and production practices. Thus, such New Mexican producers are simply referred to as local, rather than organic. I also heard the term "farmer-certified" organic used to refer to these products, which indicates that La Montañita has a basic presumption of trust in the product and, by extension, the producer.

- Finally, the Organic Local Foodshed refers to USDA-certified organic products that are from outside of New Mexico but within the 300-mile radius of Albuquerque that makes up the area of La Montañita's food shed. This mainly includes produce from parts of Colorado, Arizona, and Texas. 
The notion of "clean" food came up in several interviews. There were diverse opinions amongst the La Montañita staff about the actual value of USDA Organic regulations, especially for smaller producers.

"The USDA Organic brand is immensely valuable in the larger supply chain. The further your product goes, the more hands it goes through, the more that it's a seal of value, but local and regional food systems are short supply chains. They don't necessarily require the same kind of investment, the same kind of verification. People expect them to stand for values that are, perhaps in many cases, behind what organic stands for." - BEDC

Indeed, the USDA regulations have been perceived to have lower standards ${ }^{51}$ than other organic certification bodies or long-time practitioners of organic agriculture (certified or not). These perceptions have come more to the fore with the rise of "big organic" agriculture, which is sometimes also seen as antithetical to the spirit of organic production in some respects: the prevalence of large monoculture operations and the use of organic pesticides that may also have deleterious environmental effects, "I hate to say it, but sometimes I feel that our produce is more organic than Whole Foods produce. Do you know what I mean? The farms that we're buying from are growing cleaner, straight up. Not all organic is equal." $-\mathrm{PM}$

Yet, organic certification is a main driver for many shoppers of the Co-op, as such there will always need to be accommodation for those customers, even if a noncertified local product is available.

"When it comes down to local... again, do you want local? Some local is going to have GMOs in it. Or do you want natural, organic, completely clean, GMOfree? ... If we get it from Veritable [Vegetable], it's probably organic. If it's from a local producer, it may not be. It could be a clean product, but it may not be certified organic. That's where the rub comes in again: Local, organic, which one do you want?"-GM2

In some cases, customers have clearly voiced their preference for organic certification over local that may be grown organically but is uncertified. One grower who had an ongoing sales relationship with the Co-op found that - though her produce was

\footnotetext{
${ }^{51}$ The Organic Consumers' Association, in which La Montañita staff represents the Co-op, has long held that the USDA Organic program is very problematic and too permissive. They have been campaigning for stricter standards for many years. https://www.organicconsumers.org/campaigns/safeguard-organic-standards
} 
accepted in the low season - when many certified organic local growers offered produce in the high season, the Co-op chose to buy from those growers instead. Notably, smaller producers - who may not be able to use entirely organic inputs but who are local or community-based - may be seen as more worthy of support and given the benefit of the doubt.

"The people that approach me know that they're growing clean already, so either those farmers just don't have a certification and they're growing organically, or they're doing it, maybe, 90 percent organic. Maybe not every seed that they're using is organic, but they're definitely not using chemicals. We go out to the farms, but I can't say for certain anything, and that's why I don't label it organic." -PM

While there is general acceptance that a producer might not have the time or money to go through the organic certification process, there was an acknowledgement that the Co-op would not have the real resources needed to make continuing checks on producers and that much remains uncertain without having an ongoing specific compliance process. Indeed, I encountered varying levels of acceptance or trust in the avowals of local producers without organic certification.

"How do I know that this water [motioning to a bottle on table] is really from Colorado? Natural Spring Water. I've talked to these people. The spring actually is outside of Denver, but you know, how do you really know? ... We get that all the time. 'I grew these chicken eggs [with] no GMO feed.' How do we know that?" - CDC-WM

This expression contrasted markedly with another Co-op staff member who presumed a higher level of trust in producers supplying La Montañita, or perhaps it may indicate a high level self-confidence regarding understanding agriculture.

"We have relationships with these farmers and we go out and visit their farms and we, you know, look at their soil and look at their farm, and you can sorta tell. Anybody who's been certified organic can, sort of, generally, look at the soil and know if that soil is alive and organic or if it's been doused with chemicals." - MC

\subsection{3: Local food reflects La Montañita's organizational aspirations and expertise}

The Co-op has not only created an economic niche in local food, it has deeply invested in its own identity as a purveyor of local food. La Montañita's decades of 
experience in working with small and medium-sized local suppliers is integral to its centrality in a local food economy. The corporate systems at larger regional and national chains are much more restrictive in accepting local products. According to one cheese supplier who sells to La Montañita and to Whole Foods, an international chain focused on natural and organic products, the Co-op is very flexible and easier to work with. "[The local Whole Foods locations want the cheeses], but we have to go through the whole corporate bureaucracy to get them in the stores. It's been about a year, and they still don't have them. The bureaucracy part of that is a little crazy ... it all has to go through the regional office, and it has to be approved."

As a point of contrast, staff members are considered knowledgeable and empowered to act on local food procurement. Indeed the decision-making and autonomy of buyers at La Montañita has been cultivated by management.

"The one thing I love about the Co-op: we have very well-educated, very wellinformed staff. The Nob Hill store, the Rio Grande store, the Westside store - the last thing that they need is me going in there and making decisions for them about their product selection. Those people are experts. I don't micromanage that whatsoever. I leave that up to their discretion...They will know what the products are, how clean it is. ... That's what I pay them to do." -GM2

Still, amongst the staff, there were varying levels of concern about the "trustworthiness" of products. This partially comes from the lack of a structured intake process for local products at La Montañita. While many products sold at La Montañita are national products that may have been subject to regulatory scrutiny and other selection processes in the wider marketplace, local products may be introduced to the Co-op without layers of vetting.

"Part of the problem is, right now, anybody that's a buyer-- and there's a couple of dozen of them at every store -- you can walk in the door with something, and they can go, 'Oh, cool. I want this.' And they can go buy it and put it on the shelf. I'm a little exaggerating, but it's almost that easy." -CDC-WM

This ease of acquiring new products could allow for more flexibility and could encourage entrepreneurship; but it also has implications for the appropriateness of new products, potential overlap with existing products, and potential stability of the businesses offering local products. This is of particular import to the Long Term 
Strategic Plan of La Montañita and its hopes to help build a sustainable local food system.

"... a buyer in a store doesn't think 'What is this vendor's chance of success?' They just think 'I want the product. I like the product.' ... You have to understand that the whole purpose of the CDC was to think more broadly and with more depth of concern and understanding about what it takes to build a local, regional food system. Every vendor, collectively, adds up to make the system. If you're in department trying to put good product on the shelves, you're not thinking about the system. You're thinking about your shelves." -BEDC

The aforementioned issue speaks to the diverse nature of the Co-op and its departments, with different concerns and priorities. Though there is an important tension between immediate concerns of offering products and of thinking about the food system, there are other dichotomies that require tradeoffs as well. One is that the provenance of a product - whether raw commodity, value-added or processed - is not the first priority in acquiring it. The quality of the product was cited as most important factor across all interviews. As such, the Co-op will often stock organic products from their supplier Veritable Vegetable (VV), as well as a local product, to offer produce that will have consistent quality standards. "I'm trying to get the farmers here to meet those quality and size standards, so everything's consistent for any customer. They can pick up a chard from California, and the New Mexican chard won't be smaller. It'll be the same size or bigger, if possible." -PM

\subsection{4: Local food has social and communal meanings}

There was significant emphasis on communal social relations - and reconnecting

Advert 1: La Montañita ad touting link with local grower

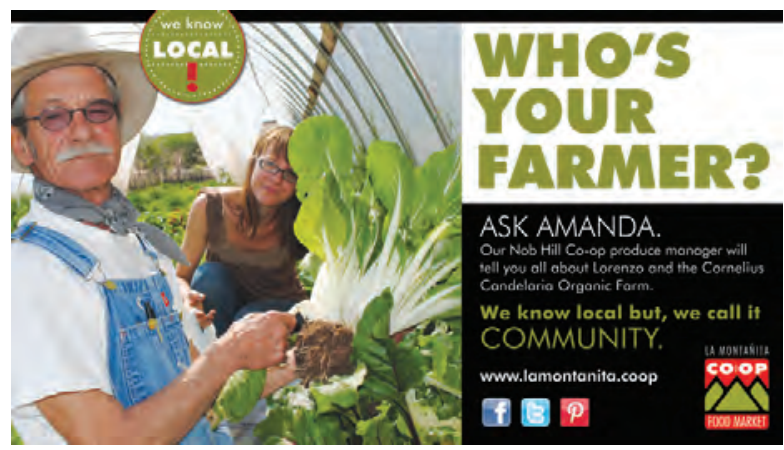

Image courtesy of La Montañita Co-op food producers, consumers, and the Co-op itself - used in the interviews at La Montañita. This occurred whether staff spoke about the Co-op as a local food system actor or as a cooperative business that must be responsive to community needs. Indeed, there was some presumption of a natural fit between local food 
provisioning and cooperative food retail. "What the local food system does, what co-ops do, is we're really about re-creating relationships." - MC Such sentiments have been expressed in other studies of cooperatives in the food retail sector (Lake and Leviten-Reid 2015; Sumner et al. 2014), though this conflation may not be as readily made in co-ops outside of North America or that have not specialized in the natural and organic food sector. Indeed, food shops in the largest and most successful cooperative retailers in Europe do not specialize in natural and organic food and also have not ventured substantially outside conventional large-scale distribution. ${ }^{52}$

Several staff members emphasized personal and organizational ties with farmers and vendors as important reasons for why local food is valued. Farmers in particular were reflected on as being members of the local community.

"It's personal to me when these farmers come in. How can I sell their product? How can we get these farmers money? That's really important to me for sure.... I think that when I have that personal connection with that farmer, I'm more connected to the food that they're bringing in... I've been to his farm. I see him. Here he is in the store right now. Whereas, if it's just this random farm, and here are these potatoes, it's almost the same as getting it from California. I don't know who they are or anything like that." -PM

\subsection{5: Local food has economic implications}

The economic and practical realities of selling local food were present in all the interviews conducted during field research, regardless of the functions or work areas of the informants. Much of the argument for the benefit of local food to economic development was epitomized by the local multiplier effect, about which La Montañita has tried to educate its Board and customer base. The local multiplier effect is a local-scale envisioning of the economic concept of the fiscal multiplier effect. The fiscal multiplier effect describes when spending injected into an economic system returns more than the actual amount of the injection - thus offering a multiplication of that spending injection, instead of just a 1:1 correlation. This happens because the money put into an economy is circulated (or spent) within the same economy, whether via personal consumer spending or

\footnotetext{
52 The food retail unit of the UK Co-operative Group only created a local sourcing team in 2014, though some of its independent members, such as Lincolnshire Co-op and East of England Co-op, have developed programs of local sourcing over the last decade. http://www.thenews.coop/88446/news/general/the-business-case-for-localfood/
} 
business operational spending. For example, if an entity spent $\$ 100,000$ on hiring for a project, wages (and thus aggregate income) would increase by $\$ 100,000$. This increase in workers' wages would also trigger consumer spending of the additional disposable income. The amount of this additional spending varies, from place to place, depending on how and where it is spent.

In the case of the local multiplier, such spending would take place at independent, locally owned businesses, rather than regional, national, or international chains that may be publicly traded. Several studies have concluded that local retail recirculates money in local communities at about three times the average of national chains (Sacks 2002), significantly boosts farm income (Meter and Rosales 2001), and creates more jobs (Shuman and Hoffer 2007). The main explanation is that local independent businesses are much more likely to spend their money locally (via business-to-business spending) for operational expenses. For example, a local tea and coffee shop is likely to have its signage created by a local graphics and printing business or have its financial accounts kept by a local accountant. A national chain will likely have all of these services done at a corporate or regional location, taking spending for those services outside of the immediate local community. Additionally, tax revenues are often forfeited by localities that offer tax breaks and incentives to attract large chain stores and national brands to an area. A study by Shuman hypothesizes tremendous economic benefit for even just a $25 \%$ localization of food in New Mexico: "Simply tapping a quarter of the opportunity available would increase output by $\$ 1.4$ billion, earnings by $\$ 345$ million, state revenues by $\$ 44$ million, and jobs by over 10,000 " (2010). While there are factors that make the local multiplier concept difficult to fully evaluate in terms of benefits, including opportunity costs to national retailers, uneven gains in rural versus urban areas, and the zero-sum nature of import substitution (Low et al. 2015), La Montañita informants frequently referenced the presumed value of a local multiplier. Internal board documents ${ }^{53}$ and staff members also mainly cited the statistic of three times the recirculation of money in an area.

The vision of import replacement that would allow New Mexico to feed itself rather than getting food from other places, particularly California, was a powerful one for several staff members. Senior staff spoke about locally producing a "complete

\footnotetext{
${ }^{53}$ For further discussion, see http://lamontanita.coop/wp-content/uploads/2013/03/2015_08_18-Board-StudyMinutes_APPROVED.pdf
} 
nutritional pallet" - meaning all essential foodstuffs for a healthy diet (proteins, fruit, vegetables, and grains) - and essential localism: "first you feed yourself, and then you trade what's left."

"What if everybody in the state ate New Mexico grown and harvested beef? How much economic development would that be for our ranchers? ... That complete nutritional pallet, to me, is about import replacement for economic development, with the food system as an anchor.... I think, besides the nutritional quality and the freshness and the environmental effects ...the economic effects are huge. All of that sort of comes together in a perfect storm of economic development, land restoration, environmental restoration and sustainability." - MC

Staff also saw import replacement as providing a means to a resilient economy, an entry point into a more powerful role in larger economies, and a way to be a player in the global economy - all in addition to increasing the availability of healthy, fresh food in the state.

"What the local and regional system provides is balance. It provides resilience. It provides a sound basis for a region or a locale to build on its strengths. ...It's unhealthy to be only a consumer. It's healthy to be a trader meaning what you produce has value. Go out into the world and trade with that value. You have a different role than if all you ever do is sit there and eat. If you sit there and eat, you're a victim. You're just waiting to be victimized" - BEDC

Also of great concern was the need to improve the economic viability of local food producers: "These local farmers, I don't want them just to survive. I want them to thrive, because I want them to grow. I want their kids to be interested in doing it. We've got to improve their economics." -GM 1 Indeed, as in many parts of the United States, the age of farmers in New Mexico is rising. According to the 2012 USDA Census of Agriculture, the average age of farmers nationally is 58.3 years, with just $6 \%$ of farmers under 35 years of age. In New Mexico, the average age is slightly higher at 60.5 years, and a smaller percentage are under 35 years of age $(4.8 \%) \cdot{ }^{54}$

\footnotetext{
${ }^{54}$ These figures refer to the age of the principle operator of the farm. Furthermore, the USDA Census includes full-time farmers, as well as those spending more than $50 \%$ of their time doing off-farm work, reflecting the necessity of farming communities engaging in off-farm work for their livelihoods. See https://www.agcensus. usda.gov/Publications/2012/Online_Resources/Highlights/Farm_Demographics/ for overall US statistics and https://www.agcensus.usda.gov/Publications/2012/Full_Report/Census_by_State/New_Mexico/for disaggregated data about New Mexico.
} 


\section{5: La Montañita's areas of work and practices engaging with local food}

As a retailing enterprise, La Montañita's work in engaging local producers cannot be reduced to paying producers more money. The Co-op must balance between getting good but fair prices from its suppliers and offering good but fair prices to its customers. "In the picture of a cooperative food system, it's not simply how do we pay the farmer the most, because the interests of the customer are there as well. The customer has to be able to afford to feed their family..." - BEDC Indeed, it is that larger vision of an inclusive cooperative food system that is the essence of how La Montañita has devised its focus on four areas - local brand development, market expansion, producer coordination and support, and distribution - vis-à-vis local food engagement. The Co-op has undertaken this work with a variety of (unprocessed

\section{Photo 4: Herbs packaged with the Co-op's local branding}

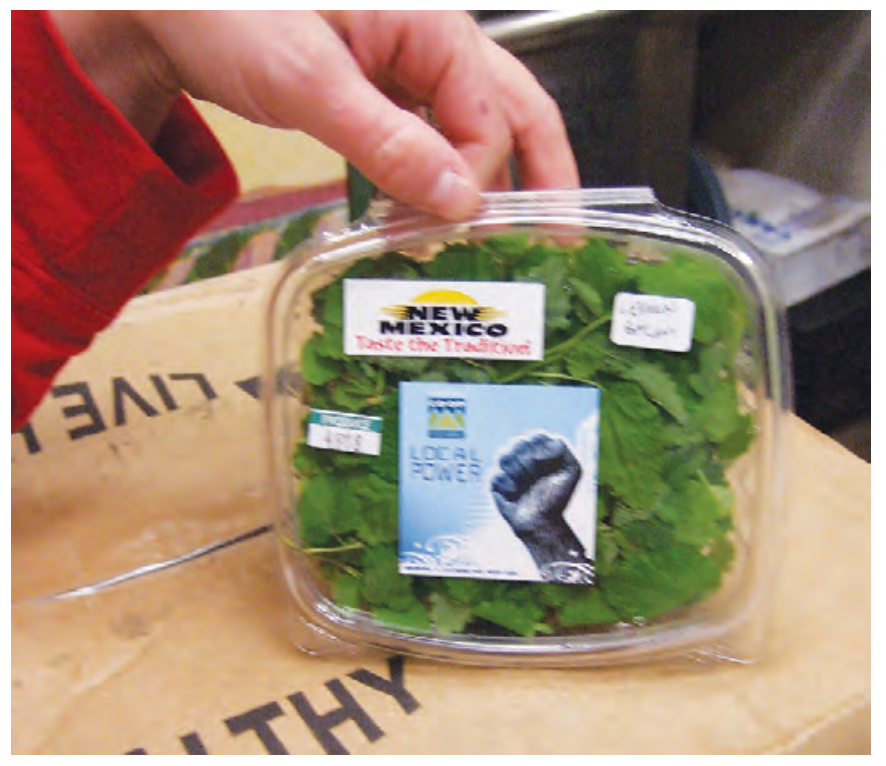

commodity and valueadded) producers at different scales, and some of that work is detailed in the following sections.

\subsection{1: Visions of import replacement}

Though the Co-op has, since its inception, gotten some amount of its produce from local farmers, the majority of the produce sold in all of the Co-op's storefronts comes from a San Francisco, California-

based organic distributor called Veritable Vegetable (VV). This firm sells fresh fruit and vegetables to many supermarkets in the natural and organic sector throughout California and parts of Arizona, Colorado, Nevada, and New Mexico. The Co-op has been able to acquire necessary quantities of products from VV, despite the pressure of a severe drought that had plagued California since 2011. Nonetheless, even before California's drought began putting upward pressure food prices, La 
Montañita considered import replacement as an integral part of its strategy to build a sustainable food economy.

\begin{abstract}
"Some really high percentage of all the fruits and vegetables that are eaten in the state come from either Mexico, Chile, California or Florida. It seems to me that, with good upscaling of the food system, we could reduce that percentage. It'll never be 100 percent, because we live in the high dessert. The amount of economic development that could occur through the food system, I think, is huge - by reducing our imports from out of state." - MC
\end{abstract}

Essentially, the Co-op's long-term plan is to source products (including produce, value-added products, meat, dairy, grains, etc.) from a 300-mile radius around Albuquerque. Thus, as a standard practice, produce buyers at the Co-op's storefronts communicate with local growers each week before placing their produce orders with VV to see what they may be able to order locally. At the time of fieldwork, it was estimated that about $20-30 \%$ of La Montañita's sales revenue came from local products.

\title{
4.5.2: Local brand development
}

La Montañita's efforts at local brand development have included an array of initiatives. In 2012, the Co-op offered approximately $\$ 12,000$ USD worth of free branding and marketing services (e.g., logo creation, visual identities for packaging, and large-format publicity materials) to suppliers. Such assistance is envisioned to be offered as needed in the short term: "Our goal is to get them started and

Photo 5: Local producer demonstrating his products

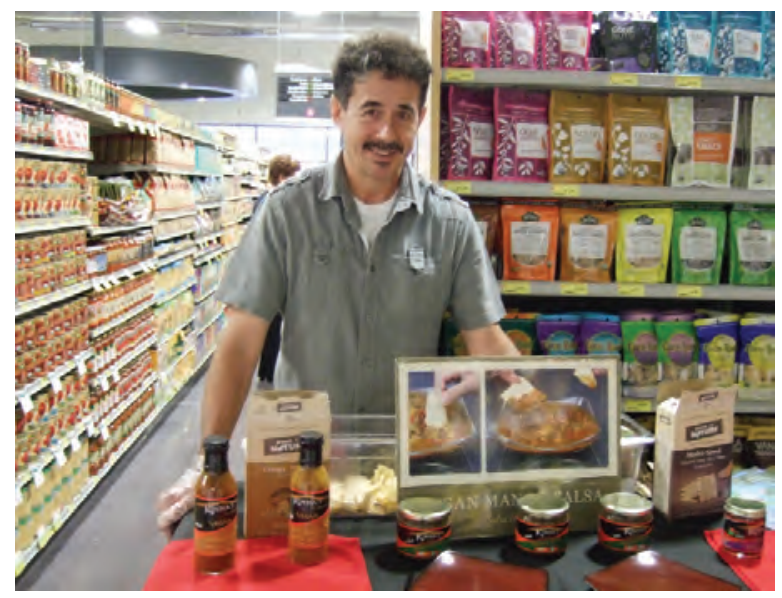
have them move forward on their own." - GM 2 Publicity material featuring producers are placed in all the Co-op's storefronts on an ongoing basis, and these materials have also been used by producers in their sales efforts outside of La Montañita, such as for farmers' markets and restaurant sales. The branding offered included labels and food packaging with logos and slogans, hanging 
banners with images of the producer (and his/her family or business operation), and hand-sized, publicity pieces and leaflets.

As part of local brand development, the Co-op also encourages and facilitates interactions between producers and customers. In-store demonstrations of products and meet-the-producer events occur frequently, particularly when new products are introduced to store locations. Just as with interactions at farmers' markets, producers are able to hear customers' desires and thoughts about their products through these encounters. This process has been described by several scholars as co-production (Veen et al. 2012; Brunori et al. 2011). In this way, customer-producer dialogue shapes food provisioning processes and the products themselves. One bottled condiment producer illustrated this in his decision to substitute evaporated cane juice for sugar in his line of sauces:

\begin{abstract}
"When I finished my demo at La Montañita Co-op, I went home. I did research on the evaporated cane juice [suggested by a Co-op customer]. After I did some reading... I changed the ingredient from sugar to evaporated cane juice. ... It's almost triple the price per pound, but it has been good. Customers that know about good health, they like it." - La Montañita supplier ${ }^{55}$
\end{abstract}

\title{
4.5.3: Market expansion
}

In the Co-op's vision of a local food system, local products need to be available and sold at more outlets. Indeed the need and capacity to scale up local and community food systems has been considered by academics and local food advocates alike (Crabtree et al. 2012; Day-Farnsworth et al. 2009; Friedmann 2007). La Montañita has sought to connect producers with other potential clients to increase and to further diversify income streams. Over the years, this has included restaurants, hotels, and local factories and bakeries. By seeking to foster long-term and repeat interactions between producers and other customers - particularly by creating value chains - the Co-op seeks to develop a more rooted local food system. One such ongoing partnership was created after a severe hailstorm damaged apple crops in northern New Mexico and pomegranate crops in southern New Mexico at peak harvest time. La Montañita bought both crops and contracted with a local juicer to make an apple-pomegranate juice, which resulted in a new value-added

\footnotetext{
${ }^{55}$ This quote comes from a supplier of La Montañita who sells through several of the Co-op's individual storefronts. Since working with the Co-op, this supplier has removed stabilizers from products, in favor of using more food ingredients; has made the product range non-GMO by switching to organic oils; and has introduced new organic items into the product range.
} 
product that also prevented farmers from losing their income from those crops. This both helped avert financial misfortune and generate revenue with a top-selling product for the farmers, the juice bottler, and the Co-op (Seydel 2011).

More typical instances around market expansion have focused on increasing customers from the hospitality industry via the Co-op's distribution operation, the Co-op Distribution Center (CDC). A sales representative positioned in the CDC was hired in 2009. This role allows the CDC to sell to customers beyond the La Montañita storefronts - about 50 restaurants and other retailers at the time of fieldwork. A significant amount of success in this endeavor has been due to the collaboration of chefs and restaurateurs who are committed to offering menus based on seasonal, local ingredients. The flexibility these chefs use in menu planning also helps La Montañita in turn, when it has supply problems with local inventory: "They want to be creative, to use what I'm able to bring them... [I can] let them know what my difficulties are with my inventory. They will find a way to help me use that up." - CDC-SR This sort of relationship requires a more intense level of interaction and communication with local restaurants and eateries, which the Co-op sees as important to a local food economy.

One such restaurant is at Los Poblanos, a historic inn and certified organic farm that mainly sources its food from New Mexico (50-60\% in low season and 80-90\% in the high season) - with $90 \%$ of that from the Albuquerque metropolitan area. Los Poblanos purchases $30 \%$ of its local food from La Montañita's CDC, which allows them to broaden their menu offerings from suppliers throughout the state and the edges of neighboring states. This also includes smaller suppliers who aggregate their products via La Montañita's CDC but could not individually supply enough of an item for restaurants to work with them. A chef cited the Co-op's interactions with suppliers as an important draw:

"They have the same belief system in the sense of supporting the local community - whether that may be agriculture, or livestock, essential oils, or soap. Whatever local is being produced, they carry. ... The Co-op has a connection with the farmers. They have a connection with the millers. They have a connection with the slaughterhouses that they deal with... They actually involve themselves with the community; they just don't do it from an office." - La Montañita institutional customer 


\subsection{4: Distribution services}

La Montañita's long-term vision and strategy hinges on increasing the amount of local food being offered for retail sale through their shops and through wholesale sales via the CDC. Distribution difficulties present barriers to market access for smaller and medium-sized producers who are mainly selling to local outlets. After producers attain a certain size, they may have too much product to be able to sell efficiently at a farmer's market or farm shop, but they are usually much too small to have access to major distribution channels. Thus, the CDC's potential customers for this service are medium-sized ${ }^{56}$ local producers, who may be defined in several ways.

"Medium isn't always largeness. Medium is structure. For example, my wife and I don't really want to sit at farmer's markets, but we grow some vegetables. If we can't grow our vegetables and be happy with a wholesale price, we may as well get out of business, because we can't tell the wholesaler to do the work for free. And we don't want to go do it ourselves." -BEDC

Distribution through the CDC would not only free local farmers and producers from the burden of distributing their product to a multitude of buyers (meaning less paperwork and communication needed and lower transport costs), but it also would allow the sale of larger quantities, more quickly, and to more outlets. Some of this happens when producers drop off their products at the CDC in a pre-planned La Montañita shipment, or it may be done via backhaul trucking. In backhauling, when a truck travels from point $B$ back to its originating point $A$, a producer can load a shipment onto the truck at point $B$ or somewhere along the route. This way, the truck is not making an empty return trip, wasting time, money, and energy. So the producer can make use of a journey whose expenses would have to be borne by La Montañita in any case and can, thus, ship things much more cheaply than doing it him/herself.

As a business function, distribution may not only refer to actual delivery of a product to some location, but it can also encompass a variety of services: product promotion and displays, communication and price negotiation with wholesale and retail buyers, recruitment of new customers, sales strategizing and forecasting, administrative

\footnotetext{
${ }^{56}$ While there were no specific parameters given (such as farm acreage, heard size, or production amounts) that the CDC uses to denote a medium-sized producer, there is a certain amount of self-selection from those producers who produce enough to need distribution services. As such, the CDC's definition of producer size vis-àvis distribution may be somewhat circular.
} 
paperwork, and dealing with customer complaints. As such, the CDC offers two programs related to distribution: discounts for delivery of goods and distribution services. The discount for delivery program is essentially a transportation service. The CDC charges a percentage of the value (approximately 20\%, regardless of the item) for the product being trucked to a sales location. The producer handles his or

Advert 2: La Montañita's distribution and backhauling network

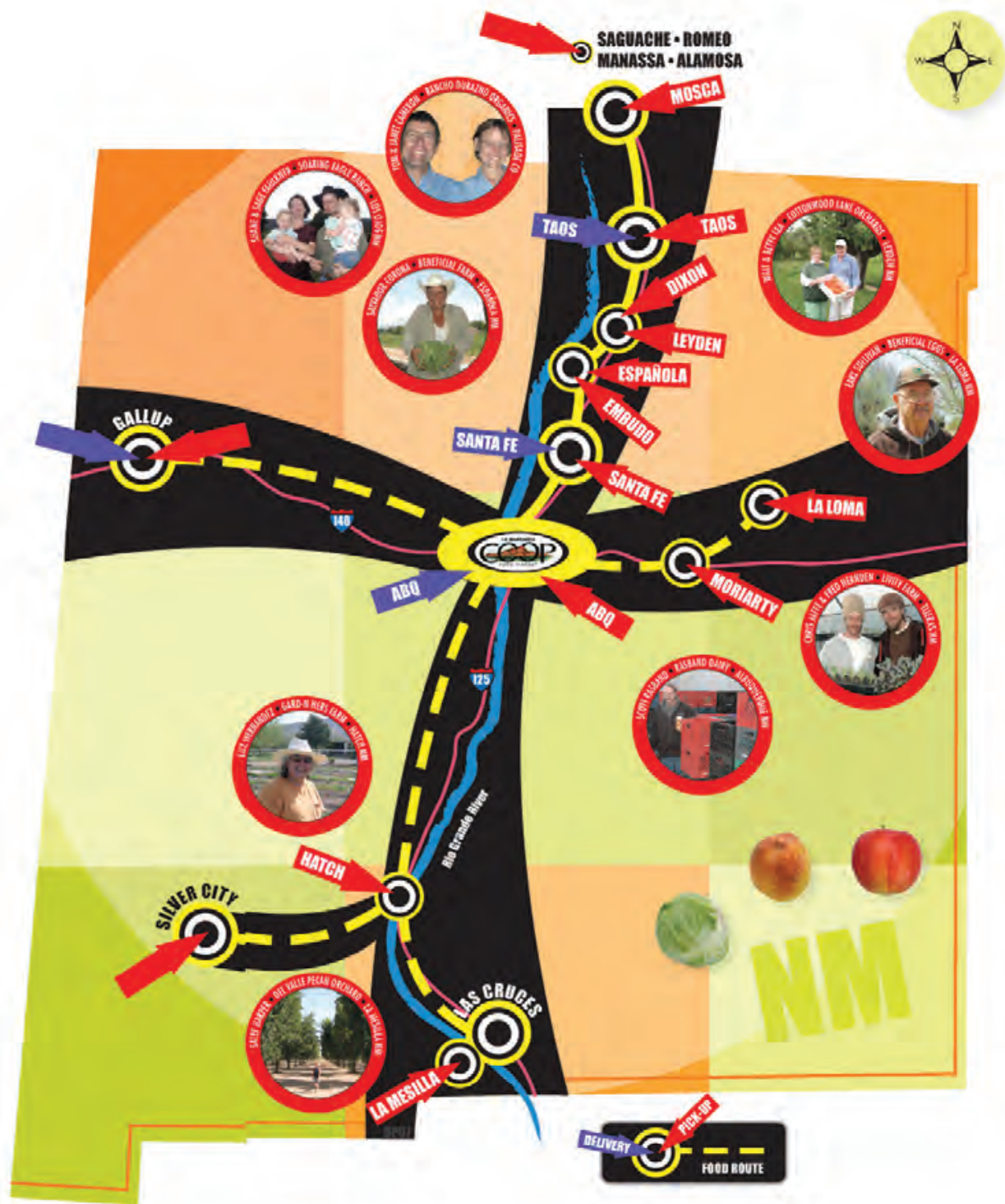


her own invoicing to the buyer directly. For distribution services, the CDC negotiates a package, depending which services are needed.

In the graphic shown (Advert 2, page 121), the purple arrows show delivery points for La Montañita's transportation routes. The red arrows indicate the pick-up points where the trucks can stop along the way to meet producers wanting to send their items to another location along the route.

\subsection{5: The Co-op Distribution Center (CDC)}

In 2006, the concrete part of La Montañita distribution vision took the form of a warehouse operation called the Co-op Distribution Center (CDC). La Montañita rented an 8000-square-foot warehouse and leased a delivery truck with the thought that it would serve as a food hub to manage and distribute produce and other food deals for the Co-op's storefronts and to other wholesale customers (restaurants, hotels, other supermarket chains, etc.). This initial configuration and emphasis on fresh produce distribution proved to be unworkable, however, and prompted a restructuring of the CDC shortly after operation began. This was largely attributed to the relative autonomy of the produce buyers at each storefront. They were free to order produce from Veritable Vegetable and individual local farmers without working through the CDC. While this was very useful in building relationships with producers and allowed personal interaction over the produce, this also meant that the storefronts were not under contractual obligation to purchase the produce deals negotiated by the CDC.

"We quickly learned that we had difficulty doing produce because, organizationally, La Montañita has not sent a leadership message that, as a priority, we should work produce together... Our own stores had been also given a message through our own organization that they were special and could do all their own buying and make all their own decisions. So it was not a good flow relationship between opportunities that came to the CDC and getting participation and support from our stores as customers, as buyers." - CDC-WM

Because La Montañita's own storefronts represented over 50\% of the CDC's sales, any large produce deal would require participation from those storefronts to be successful. Institutionally, La Montañita had not communicated a unified message for produce departments to coordinate with the CDC, and the CDC was forced 
Photo 6: CDC warehouse set up to host the Co-op's annual meeting in 2013

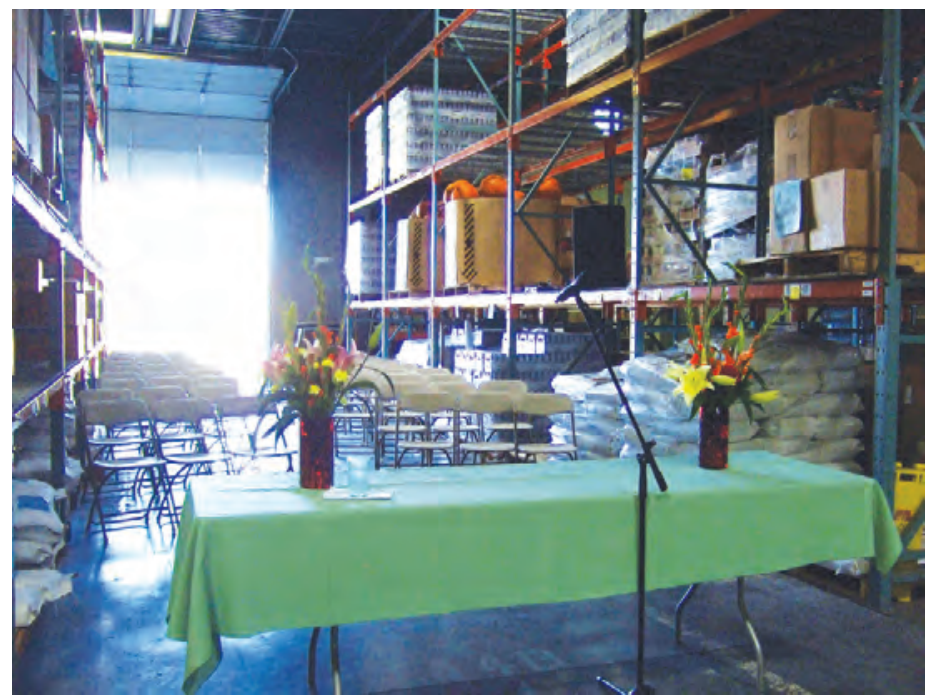

to adapt to that reality. During this initial period beginning in 2006, the CDC was running a deficit of approximately $\$ 150,000$ each year. This lasted for several years.

As such, the CDC soon limited its local fresh produce purchases to less perishable items such as apples, stone fruit, potatoes, onions, carrots and other root crops. These could be sold to the storefronts and other customers with less urgency. Otherwise, the bulk of what the CDC distributes comprises (local and non-local) meat, cheese and dairy products, ${ }^{57}$ non-perishable items, and shelf-stable grocery items bought under contract through the National Cooperative Grocers Association. This proved to be a better way forward financially, and the CDC went from losing approximately $\$ 77,000$ in 2013 to projecting breaking even by 2014 .

Although the CDC moves quite a lot of local food shed product through its network, a significant amount of the food distributed by the CDC includes dairy products from Organic Valley, a large organic producers' cooperative based in the Midwestern US state of Wisconsin. Having such a large and important player in the organic foods sector as a partner helped establish the credibility of the CDC. As the CDC stabilized its finances through its distribution of Organic Valley products, it began to market its distribution services more strongly. The success that followed led to needing more space. In December 2011, the CDC moved to an 18,000-square foot facility

\footnotetext{
${ }^{57}$ La Montañita and the other main case study location in this research each categorized cheese apart from dairy department items. Thus, they are spoken of separately when mentioned.
} 


\section{Advert 3: CDC advertising for producers and institutional customers}

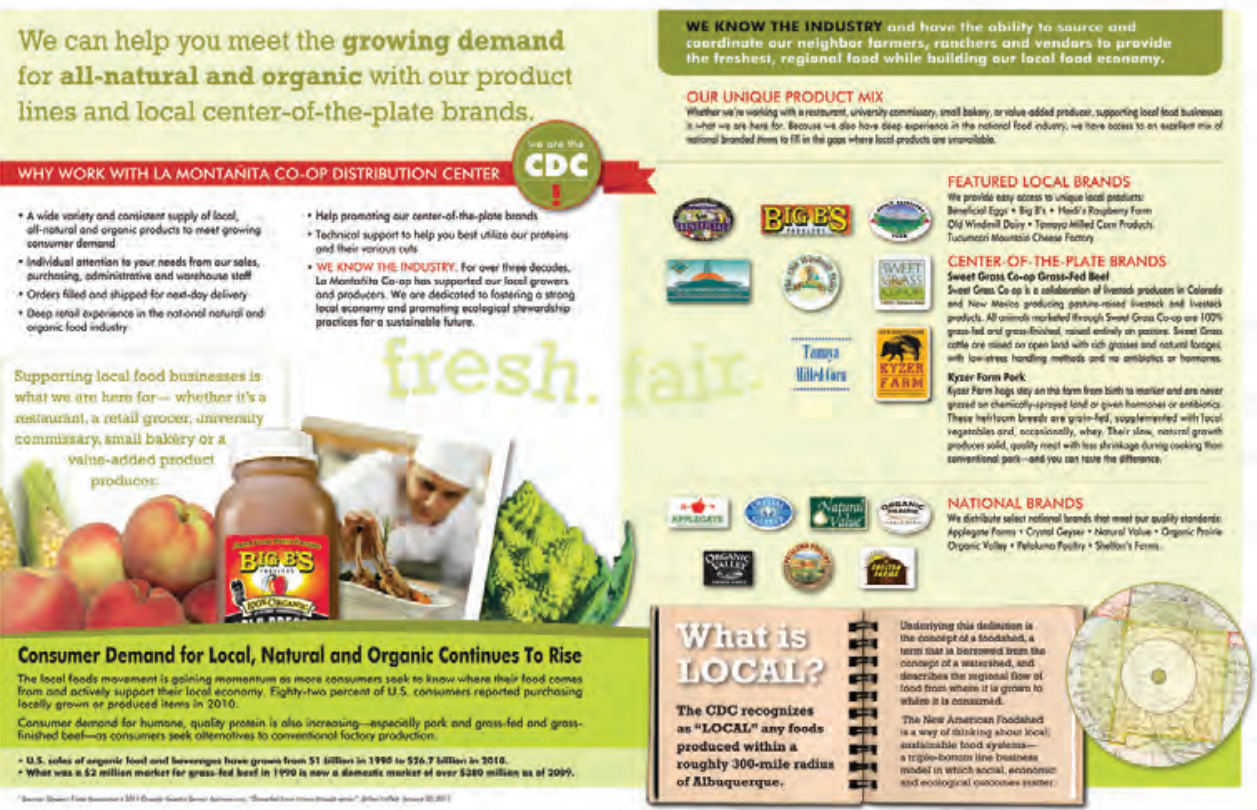

New Mexico's Premier
Cooperative Distributor
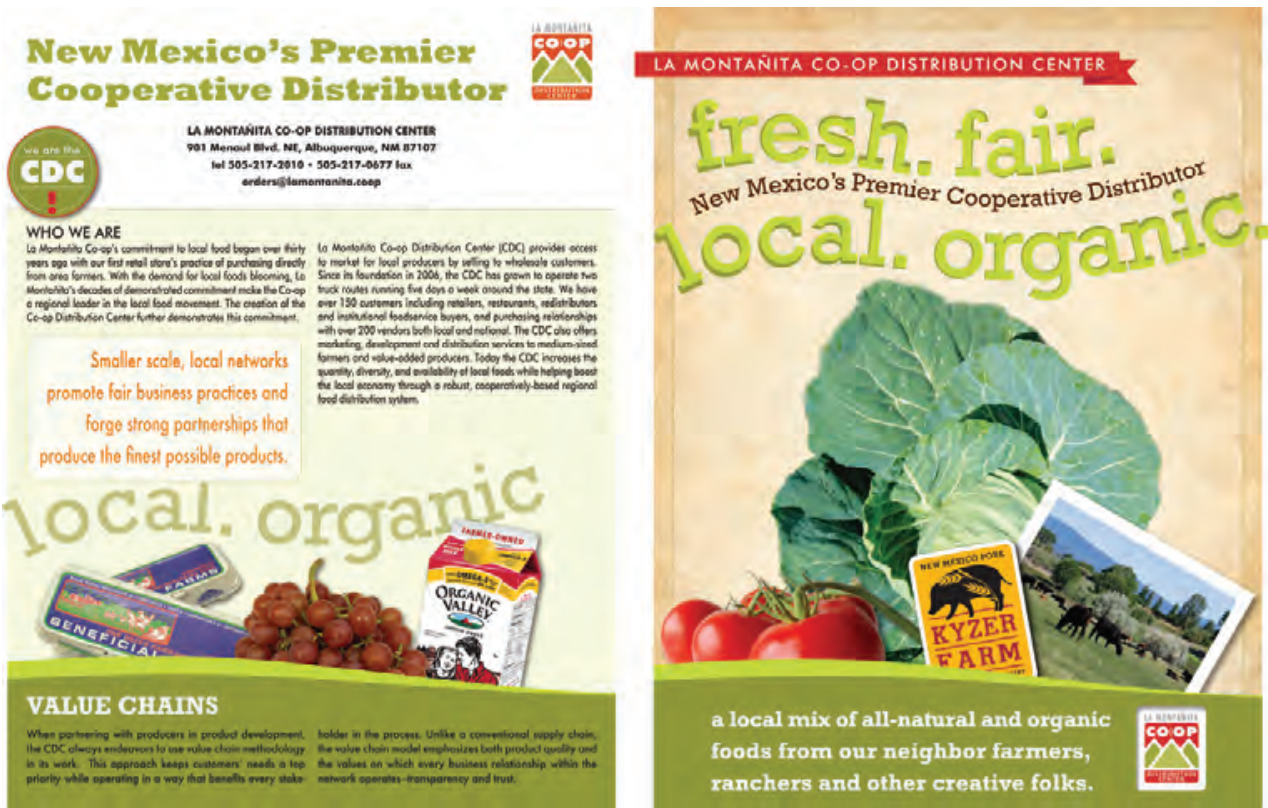

Image courtesy of La Montañita Co-op 
working with a staff of 6 full-time employees. At the time of fieldwork, the CDC was running two trucks for 6 days of the week and was working with 400 local producers (selling over 1,100 products - dependent on the season) throughout the state.

\subsection{6: Perceptions of the CDC and of distribution processes}

The CDC is a subsidiary business of La Montañita, but it is separate from its storefronts. The CDC markets its service via its web site, which is accessible both through its own URL and through La Montañita's main site. There also have been other small-scale publicity efforts via the Co-op newsletters, farmers' conferences, and word of mouth. CDC staff members acknowledged that more could be done to encourage the produce departments to work with the CDC. Though they definitely identified possibilities for more cooperation with storefront staff for high-volume produce purchasing, they understood the desire of storefront staff to work with farmers directly.

"Produce is very much a personal business. Good produce buyers - which our stores have excellent produce departments - want to talk to people. They want the same kind of customer service in relation to their suppliers that they are expected to give to their customers. Produce is not a buy-from-a-list, email-meyour-order kind of business. The CDC has, in order to garner the opportunity, to do more communication. What I think moves the produce buyer in the store is

"Who do I trust - because I talk to them. Because I built a relationship. Because I have history." - BEDC

I encountered some unfamiliarity among storefront staff members about how the CDC operates. People voiced presumptions about why the $\mathrm{CDC}$ did not receive much produce: the staff there did not have time for the handling it requires. According to a produce manager: "That was part of why the warehouse doesn't handle certain products, because there's nobody there to touch it, look at it, talk to the farmer." While it is correct that the CDC distributes many products that are packaged durably and have no particularly sensitive handling needs (e.g., coconut water, toilet paper, and pet food), there is typically some amount of inspection for the produce that comes in - but certainly not as much interaction as at the storefronts. With respect to local food and the high amount of guidance needed by some local producers, there would not be that opportunity through the CDC.

"That education that I was telling you about, when we work together, that's all lost when we [have no direct contact]. We do have these farms that I order 
from the warehouse, and I don't know who they are. I've never been to their farm. I don't know the farmers' names. Yes, I think that when I have that personal connection with that farmer, I'm more connected to the food that they're bringing in. It is really important." - PM

Use of the CDC was rather limited amongst most of the producers I encountered, including one who was vocally lamenting having to drive to Santa Fe 65 miles away (approximately 100 kilometers). That producer, who was selling to 3 La Montañita storefronts, 2 locations of the Whole Foods market chain, and some smaller outlets also had a full-time job outside of his food business. As such, he fell squarely into the CDC's target group of medium-sized producers, but he did not know of the $C D C$ 's existence and so dealt only with the individual storefront managers.

Some producers also knew of the CDC but found its services too expensive or perceived that the CDC (as a buyer) offered farmers prices that were too low. One farmer singled out the discount for delivery program as being unfair, because the fee was charged on the value of the product, rather than the actual space and fuel costs involved in transport. (For example, the dollar value on a small box of garlic or specialty mushrooms would be higher than several boxes of potatoes that would take more up more space and use more fuel to transport). Another farmer cited a convoluted situation that had occurred when the CDC bought some lettuce from a network of farmers at a price that was far less than what the storefront produce managers had paid for that same lettuce. The farmers, who in a great hurry to sell their product, had approached the CDC on short notice and were disappointed because of the low price they received. They felt wary about selling to the CDC in the future.

Though there were some specific cases of dissatisfaction or confusion regarding working with the $\mathrm{CDC}$, there were some significant success stories offered (mainly from value-added producers, rather than vegetable farmers). This may be indicative of what CDC staff characterized as local producers' poor understanding of market segmentation and volume distribution. It is, at least, a disconnect in communication of their mission between the CDC and producers. CDC staff stressed that not every item is really ready for distribution and that producers must understand the difference in price points when products are sold at a farmers' market directly to individual customers and when that same product is sold in much larger quantities into a distribution network. Additionally, there are several local non-profit 
organizations that are offering distribution services to farmers at a loss. They are essentially community organizations that are self-funded or grant funded with no need to break even or turn a profit for their work. It may be that these organizations provide producers with a false understanding of the prices the market will bear on different levels.

"I think the CDC is looking to work with the mid-sized farmer, and that's what I'm always saying. Not the backyard, semi-retired scientist that makes $\$ 100,000$ a year in their retirement fund and then has beautiful tomatoes, but wants me to pay this high price for their tomatoes. ... Believe me, they should go to the farmers' market and sell their tomatoes for $\$ 5.00$ a pound. They should. And great! They have beautiful product! But don't get resentful of a distribution system that's really made for volume and has to pay for itself because we are not a nonprofit." - CDC-M

\subsection{7: Producer coordination and support}

With respect to producer coordination and support, La Montañita found that some of their suppliers had limited experience in the essentials of marketing to the Co-op or to other entities, such as restaurants. "I think a lot of farmers have no idea where to even start. They don't know what it is we want. They don't know pricing, they don't know packaging." - PM In an effort to make local produce easier to handle, both for the Co-op's produce managers and for other retail and wholesale customers (such as restaurants), La Montañita created a manual and has offered training to producers. This training covers such issues as displaying, arranging, and packaging of various types of products; communication about the readiness and availability of crops; and working with different sectors of the market to maximize income streams.

One farmer explained how advice from La Montañita has increased his sales to the Co-op and to other customers. "I've learned how to pack my food better so that it becomes more uniform. It's stored better. It's better labeled. [The Valley store PM] gives out advice." - La Montañita supplier ${ }^{58}$ In one specific instance, by following suggestions about bunching together different varieties of chard and carrots by color, the farmer was able to quadruple and triple his sales. The specifications that

\footnotetext{
${ }^{58}$ This supplier sold to La Montañita's Valley store location, though not to other locations or via the CDC. His main business was through farmers' markets and institutional customers at the time of fieldwork.
} 
La Montañita requested also rang true with local restaurateurs, whom he was now able to serve better.

This is not to say that the Co-op's staff members have always embraced accommodating local products. A former General Manager characterized local food in less generous terms in comparing it to Veritable Vegetable:

Photo 7: Produce staff receiving local delivery
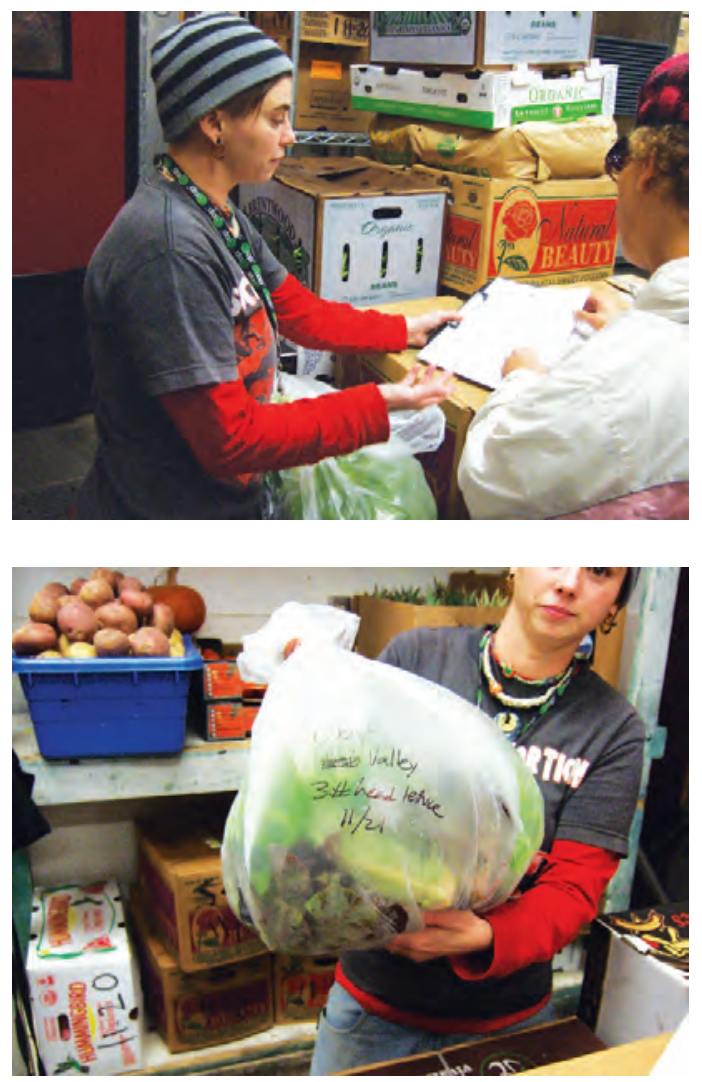

"It's a constant battle. Local is hard. They're already getting this truck from California three times a week. Very professionally done, outstanding quality, the same every time. [Then], we ask [produce managers] to deal with local farmers who don't have a clue. ... The local stuff is a pain in their butt. It's a constant education, constant push/ pull, bribing, whatever. ... Compared to this gorgeous, beautiful stuff out of California. It's a challenge."-GM1

Some farmer training and education was already being done on an ad-hoc basis by some of the produce managers, but the need for a more consistent educational approach throughout the Co-op was recognized. This was especially the case for farmers who were selling to multiple La Montañita storefronts. Having basic uniform standards allows the same prices to be offered to farmers selling to each Co-op location. The establishment of such standards could not be done without consistent product from the farmers or without better communication and coordination between La Montañita's produce departments.

Because of the autonomy of the individual produce departments, such coordination was not standard practice until shortly before the point of fieldwork. Thus the 
Advert 4: La Montañita guidance to local growers
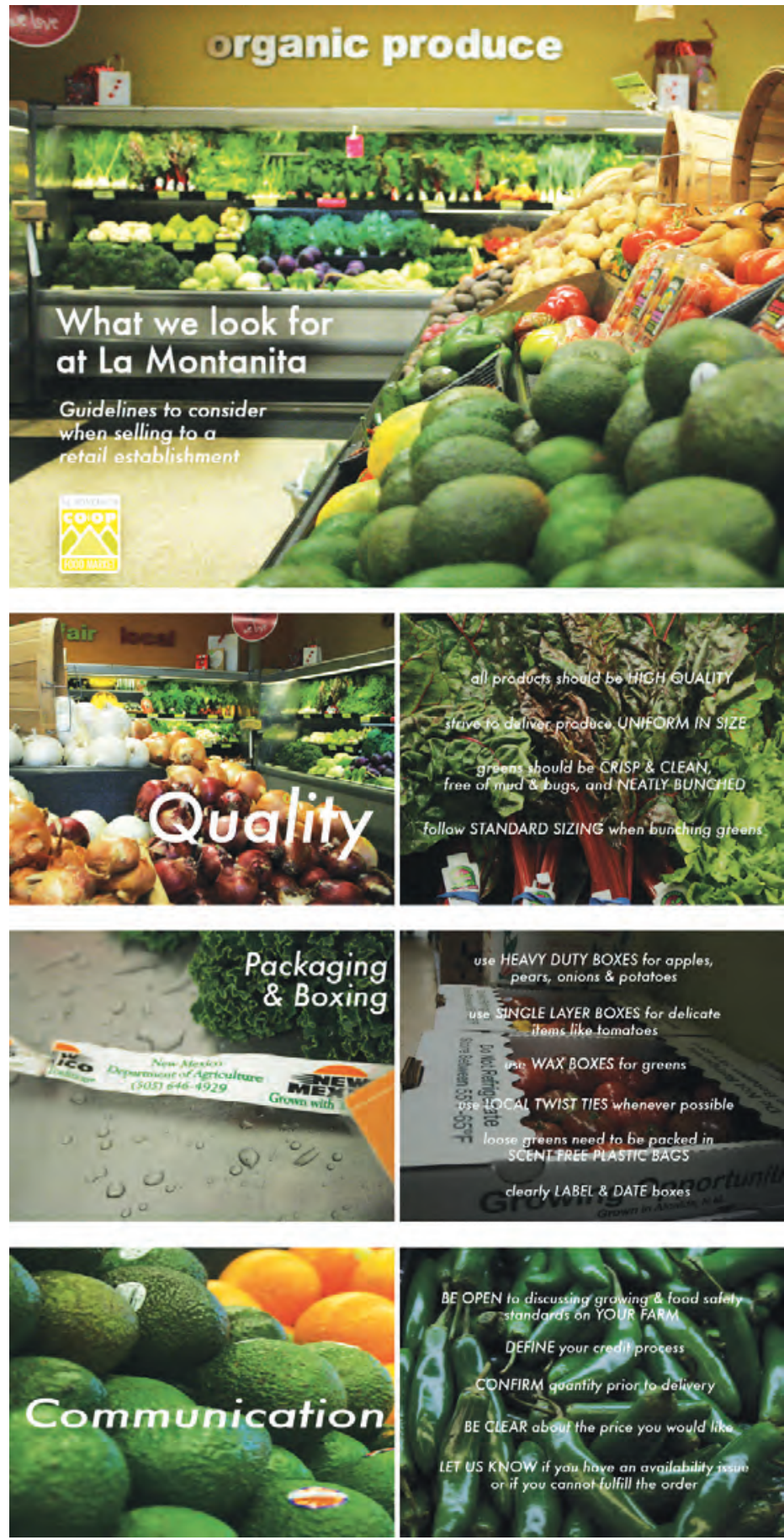

Image courtesy of La Montañita Co-op 
Co-op's efforts to professionalize farmers also had a positive effect in coordinating their own operations. Speaking of the new practice of the produce managers working together, one opined:

Photo 8: Branding materials created by La Montañita Co-op for local suppliers
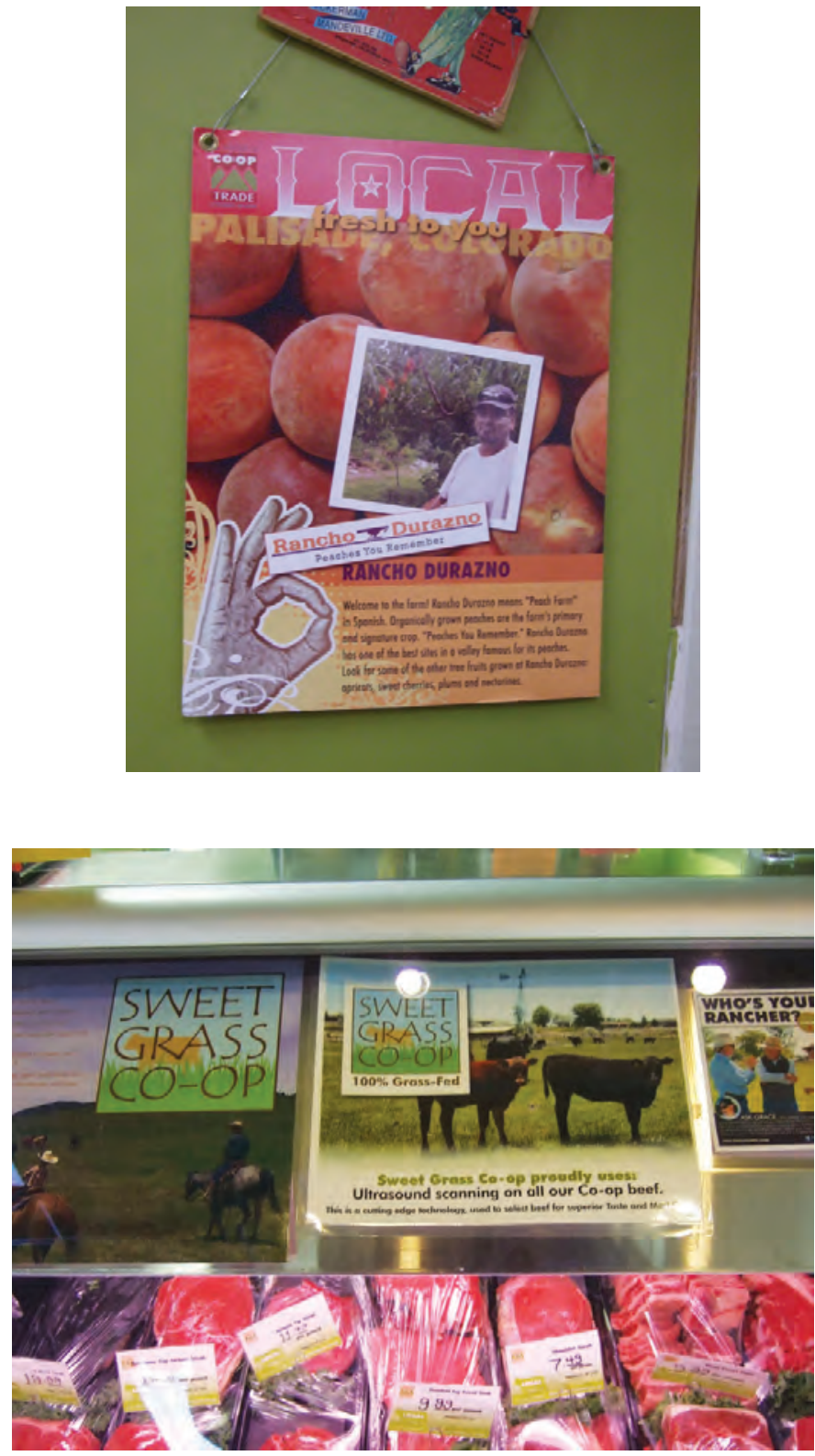
"It's been really good. It's been good for the farming community, too. I think we've been able to bring a lot more product into the stores... and they know what they're going to get from us." - PM

In addition to the individual education offered through interactions with produce department staff, La Montañita also presents grower workshops at New Mexico's most important organic farming conferences and events. Making presentations at the farming conferences also offered the opportunity to foster the coordination apparently missing between farmers.

"I think [coordination is] something we're definitely missing in New Mexico. We have a farming conference every year. They can come, and they talk to each other, but I'm not seeing them coordinating what they're growing on their farms and their distribution lines." - PM

Similarly a cheese producer familiar with dairying communities in the East Coast state of Vermont contrasted the producer culture found in New Mexico.

"Every one of them knew what the other person was making, where they sold. They talked to each other. They helped each other. It was like a big giant family making cheese back there [Vermont]. You get out here, and you don't see that in anything. You don't see it in the beef. You don't see it in the vegetables. When there were other cheese producers here, you didn't see it in that. I've been told that it's the mentality of the West, that the people out here are very independent."

These efforts at coordination among producers were also envisaged to help La Montañita in being able to diversify and expand the range of local products. This has indeed happened, both overall in the Co-op's offerings and within the ranges of individual suppliers. (One cheese supplier has increased his variety of products by over $50 \%$ since working with La Montañita.) Some La Montañita staff members emphasized the significant potential for increasing the amount of local production by having more coordination between the Co-op and local producers. "There's plenty of stuff during local season that I still have to buy from California that, really, I think local farmers could grow. I try to communicate that to them, but sometimes they just want to grow the stuff they know." - PM

Despite the possibility of increasing the variety of products available from local producers, there is a recognition that producers have a lot of risk-aversion in the 
already risky endeavor of agriculture, which makes it better to start where they are. "You don't go up to a producer and say if you had this, I'd buy it. You go up and say what have you got? What can we do with that? They need success. Everyone needs immediate, relative success." -BEDC

For growers working with the storefronts, La Montañita's produce managers can offer a high level of interaction, especially for new producers. Repeatedly mentioned was the support from the produce manager at the Valley location who did things including trimming stems and rehydrating already-delivered produce for presentation, ordering (or otherwise providing) packaging and boxes for farmers, and being creative about selling produce that might have shape, size, or cosmetic imperfections. That produce manager spoke of selling some arugula (rocket) from a local farmer. The product had its leaves eaten by insects just before harvesting. Due to the pattern of the holes, the produce manager helped the farmer market it as "lacy arugula" and was able to assist him in selling it to the deli department of one storefront and to some restaurants, despite (or because of) its appearance. "It gave it new life. We try to work things out. If farmers have stuff that's damaged, we'll try to figure out something we can do with it. Sometimes, it's a lost cause. There's nothing we can do, but we try." - PM

\section{6: Financial support}

Securing funding is a problem for small producers engaging in local food, so La Montañita's work regarding financing has been quite helpful to their network of suppliers. Often, banks and financial institutions require farmers to put up their land and operations as collateral in return for a loan. Though financial support was not a specific part of the Long Term Strategic Plan, the Co-op saw potential to help address the needs of local suppliers regarding cash flow. Two programs have evolved over some years to address this: the prepayment program and the La Montañita (LAM) Fund.

\subsection{1: The prepayment program}

In the prepayment program, La Montañita prepays producers for their product over a set time period by advancing payment for some amount of product and then allowing the producers to deduct a portion of that amount from their subsequent invoices to La Montañita. This allows producers to have capital for various businessrelated expenses they may not otherwise be able to pay for. This was seen as a 
key way to help local producers continue to meet and expand their production to supply goods to the Co-op. It has only been used on an ad-hoc basis for producers already selling through the CDC.

\subsection{2: The La Montañita (LAM) Fund}

A more open financial instrument was created to help provide a structured way to allow La Montañita members themselves to invest in a local food economy. A micro-finance movement called Slow Money held its first public conference on community investment in Santa Fe, NM in September 2009. At the end of the conference, attendees approached La Montañita - who had catered and cosponsored the conference - expressing a desire to contribute towards building a local food economy. Seeing that ordinary people from the community wanted to invest in local food, a La Montañita employee consulted some relevant foundations to explore the possibility of creating a funding mechanism. "I had read about the Grameen Bank and all the micro-lending that's going on in Southeast Asia and India and South America and Africa, and thought we're like a third-world country here in New Mexico. We should have this here, and nobody's doing this. ... Why do we only go to hedge fund managers instead of community grassroots investing in our own communities?" - MC

The following year after substantial board-level discussions, the Co-op created the La Montañita (LAM) Fund to help meet this need. The LAM Fund offers noncollateralized loans to local producers in amounts typically ranging from $\$ 500-5000$ USD, though the fund has loaned larger amounts as well. These loans - which are technically funded as high-risk securities - are unlike regular bank loans, which are usually inaccessible to farmers and small food businesses in any significant way. The fund is able to loan to food-based businesses or non-food businesses that use a cooperative business model. The loan recipients are not required to offer assets (such as their farm property, equipment, etc.) as collateral in case of default. Instead, shares purchased by individual members of the Co-op and by the Co-op itself underwrite the loans. Individual investors must be La Montañita members who live in New Mexico, and they can invest up to $\$ 10,000$ (at $\$ 250$ per share) in what are called $B$ shares. The Co-op - in order to mitigate risk and to protect member investors - has offered $\$ 25,000$ worth of $A$ shares to the LAM Fund. This means that, in case of any fund recipient's delinquency or default in payment, the $A$ shares from the Co-op will be used before any B shares to cover the loss. 
By 2011, the Co-op had raised $\$ 97,000$; made loans in the amount of $\$ 34,500$ in non-collateralized loans that paid for farmers' seeds, polytunnels, vehicles, etc.; and paid $2.1 \%$ back to investors. The LAM Fund has also helped farmers to access funding programs from the USDA and other funding sources that offer reimbursement-only payments. In 2012, the Co-op made an additional $\$ 109,000$ available to borrow, though the return on investment was just $1.67 \%$ that year. There were no defaults or delinquencies during the first year; there had since been a single default at the time of field work. The loan recipients - about 15 in total by then - had to submit an application and a credible business plan, and La Montañita helped advise them through the process. As La Montañita is interested in building a local food economy, LAM Fund applicants and recipients are not required to sell to the Co-op; they just need to have a viable market. In this way, the Co-op also contributes indirectly to the overall success of local businesses and the local economy. Approximately $60 \%$ of loan recipients do business with some unit of the Co-op (the CDC or individual storefronts). La Montañita does not insist that loan recipients use completely organic practices or be certified organic, but an applicant's chances of acceptance are much higher if they follow principles of organic food production.

All the loan fund recipients interviewed described the process as very easy with low levels of administrative paperwork and without necessarily having to travel into Albuquerque offices. Typically, the application committee reviewed submissions very quickly, with funds becoming available between two weeks to one month following the submission of application materials. An early fund recipient who had sold

Photo 9: Grower displays packaging paid for by LAM Fund loan

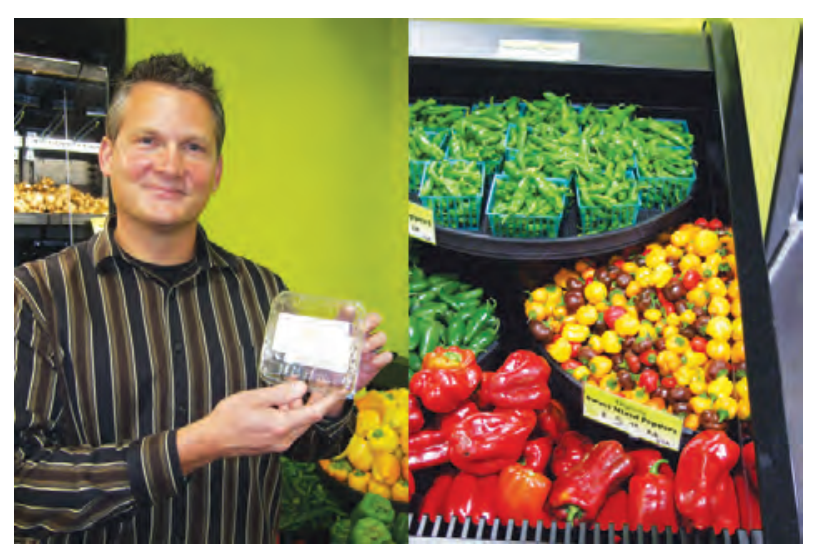

extensively and with a good track record to the Co-op recalledwritingaletter, rather than filling in an application form. Importantly for some recipients, La Montañita is flexible in view of the challenges faced by small food businesses and familyowned farms. They seem quite willing to renegotiate repayment terms and extend producers' borrowing terms: 
"A kid got sick. I got pneumonia. I had a flood. Whatever happened. We often will call the credit union and say we want to give them a [repayment] hiatus for a month or four months."- MC

Throughout the Co-op, there were a variety of ways to engage with and support local food, depending on the business function of the staff members concerned. For some producers, initial successes with La Montañita have opened pathways to business growth, and boosted their confidence. This goes well beyond the sales that the producer is able to make with the Co-op. Such was the praise from one farmer for a produce manager:

\begin{abstract}
"She was vital as a sounding board [regarding] availability, planning, and many other aspects ... in developing the packaging and labeling for 2013. She even added shishito peppers to my farm plan for the year (and followed through with purchasing everything that I grew!). She also pushed me to apply for the La Montañita Fund loan [program]. This was also instrumental, as those funds helped purchase a lot of upgrades to my farm and my packaging and delivery methods for all of my clients.... [My work was] recognized and supported by everyone at La Montañita. With that support, grew my confidence in growing and selling." - La Montañita supplier ${ }^{59}$
\end{abstract}

\title{
4.7: Post-fieldwork developments
}

As mentioned in the Research Methodology section, I learned of important developments at La Montañita Co-op that occurred after my field research and follow-up contact ended in 2014. Because these changes have implications for addressing the framing of local food in the Discussion chapter, I have included some discussion of them here. Because of the controversial nature of some of the disagreements and issues, I am reliant upon the very polarized views of different parties - including information and statements that may be inflammatory or incorrect. As such, I have attempted to indicate the perceptions of the problems from the main sides involved.

\subsection{1: Times of change and challenge at La Montañita}

There was significant change at La Montañita Co-op in 2015 and 2016. In April 2015, the General Manager (GM) who was in post during the fieldwork for this research

\footnotetext{
${ }^{59}$ This grower sold directly to storefronts and via the CDC for some time. After building his capacity, he ceased his wholesale operations (including supplying to the Co-op) and leased a retail space to sell directly to customers in a CSA format.
} 
resigned from the Co-op to take on another role at National Cooperative Grocers (NCG), a business services co-op for food retail co-ops. The La Montañita Operations Manager Bob Tero was appointed to serve as the Interim General Manager while recruitment was conducted to fill the post. Mr. Tero, who had worked for the Co-op for eight years and was very well regarded by his colleagues, was on the shortlist of finalists for the position when he died suddenly in October 2015, a few days prior to his job interview. After a short period in which the store manager at the Rio Grande (Valley) location served as Interim General Manager, one of the remaining recruited finalists, Dennis Hanley, was chosen to become the GM in December 2015. ${ }^{60}$ Mr. Hanley had several decades of retail food experience at local, national, and international levels before taking on his role at La Montañita - though nearly exclusively in conventional supermarket retailing, and none at all in the cooperative world. ${ }^{61}$

Mr. Hanley was at the helm when La Montañita instituted a significant change that surprised many of its customers. The Co-op long had a reputation of selling organic food, with some customers thinking that all fresh produce sold was USDA-certified organic or "farmer-certified" organic. Considering the emphasis on organic and "clean" food and the only very small amounts of conventional produce actually in the shop locations, it was understandable that some customers were under this mistaken impression. Still, in a bid to offer less expensive produce to its customers on lower incomes, La Montañita began selling "The Clean Fifteen" at their shops in March 2016. The Clean Fifteen ${ }^{62}$ is the collective name given to a list of conventionally grown fruits and vegetables with the lowest amount of pesticide residue in tests, as determined by the Environmental Working Group (EWG), a Washington, DC-based think tank and advocacy organization. Though La Montañita's management said that this move was in response to customers repeatedly complaining that prices at the Co-op were too high, ${ }^{63}$ the introduction of conventionally grown produce

\footnotetext{
${ }^{60}$ A timeline of this can be gleaned from The Co-op Connection newsletter issues from May, June, and December of 2015 and from January and February 2016. http://lamontanita.coop/connection/

${ }^{61}$ See https://www.linkedin.com/in/dennishanley for his professional experience and background.

${ }^{62}$ Information about the Clean Fifteen and the Dirty Dozen - the list of produce with highest pesticide residues

- is available at https://www.ewg.org/foodnews/summary.php and is part of an annual EWG report called the Shoppers' Guide to Pesticides in Produce.

${ }^{63}$ Though the Clean Fifteen are to be brought in, the Co-op stated plans to increase offerings of organic food reasoning that the competitive marketplace requires acknowledging a new normal in retail grocery because organic produce is widely available. https://www.abqjournal.com/748176/the-times-they-are-a-changing-at-theco-op.html
} 
sparked shock and a backlash. I found no particular indication whether the Clean Fifteen would be sourced locally.

This backlash seems partially due to poor communication and signage that this change had occurred, even including at the point of sale. Though La Montañita did issue a web site press release and also sent an email about this change to its member-owners in March 2016, ${ }^{64}$ some member-owners felt that the email was so poorly worded that they did not understand the change that was about to happen. ${ }^{65}$ Moreover, customers were angered that the Co-op had not specifically solicited input from member-owners, or routine shoppers, before this decision was implemented. For others, it was unconscionable that this decision was considered at all, given the environmental implications of conventional agriculture.

This was not the only major controversy that the Co-op was facing. Staff were disgruntled with new personnel strategies implemented by Mr. Hanley that resulted in reductions of working hours, alterations of employment expectations, and external hiring of senior staff. Employees also raised concern about racial discrimination, unfair promotion and compensation patterns, and the creation of an inhospitable work environment that finally led to a successful campaign to unionize under United Food and Commercial Workers, Local 1564 at the Valley storefront location. This unionization process - which was either not successful or not pursued at other Co-op storefronts - was reportedly met with antagonism, retaliation, and bullying. A legal suit was brought against La Montañita via the National Labor Relations Board (NLRB). ${ }^{66}$ Though it was unclear whether the charges of discrimination and an unfair and inhospitable work environment were made with respect to Mr. Hanley's tenure, he was blamed and personally attacked for much of the dissatisfaction and the changes that were taking place. ${ }^{67}$ Despite this, many of the new strategies were seen as necessary actions to turn around the ailing financial fortunes of the Co-op,

\footnotetext{
${ }^{64} \mathrm{~A}$ press release introducing the Clean Fifteen for sale at La Montañita storefront as part of a rationale to offer more choice in pricing is available at http://lamontanita.coop/wp-content/uploads/2016/03/LMCclean15.pdf ${ }^{65}$ These meeting minutes show member-owner and customer feedback offered at the first Board meeting following public announcement of the sale of the Clean Fifteen at the Co-op's produce departments. http:// lamontanita.coop/wp-content/uploads/2013/03/2016_03_15-BOD-Meeting-Minutes_APPROVED.pdf ${ }^{66}$ An undisclosed informal settlement was mandated by the NLRB, and the case was completed at the end of September 2016. https://www.nlrb.gov/case/28-CA-174708 Filing a Freedom of Information Act request would be necessary for further details.

${ }^{67} \mathrm{Mr}$. Hanley penned an open letter to address some of the issues and changes happening at La Montañita and to highlight positive developments that have occurred under his leadership. He also disclosed actions against him (including car tire slashing). http://lamontanita.coop/wp-content/uploads/2016/09/GMOpenLetter.pdf
} 
where membership was on a downward trend, leading management to find cost reductions and efficiency improvements. ${ }^{68}$

\subsection{2: Taking back the Co-op}

Still, some members of the Co-op community saw these matters as something more insidious: a lack of democracy, an increasingly "corporate" mentality and unwise pursuit of growth, and the Board's unwillingness and/or inability to hold the GM to account. ${ }^{69}$ By summer of 2016, a faction of customers and member-owners formed a group called Take Back the Co-op. They created a website and began collecting signatures for a petition to reverse some of the changes the Co-op had implemented, intending to "Return Co-ops to Democratic Member Control."70 The immediate goal of the petition was to garner signatures from $10 \%$ of the membership $(1,600$ member-owners) to call a Special Meeting to remove current board members, elect new ones, and bring new direction to the Co-op. Through participation in the regular annual election cycle ending on 14 November 2016, candidates endorsed by Take Back the Co-op won all four La Montañita Board member places available, with five times the voter participation as in typical election years. ${ }^{71}$

According to the Take Back the Co-op web site - though not mentioned on the Co-op's web site - in mid-December 2016, La Montañita reversed itself. With the reasoning that neither change was profitable, the Co-op decided to remove the Clean Fifteen from its stores and to revert to its distribution arrangement with Veritable Vegetable. Though this was a significant victory for Take Back the Co-op, it sees its mission as incomplete without addressing the influence of other organizations they characterize as pushing a corporate, expansion-oriented growth strategy on La Montañita and other co-ops in US food retail. These organizations are NCG and CDS. Though both of these organizations are co-ops themselves, the aforementioned NCG and CDS Consulting Co-op - a consulting firm staffed by cooperators with

\footnotetext{
${ }^{68}$ The Manager of the CDC released a letter to clarify some of these strategies, which also saw the termination of a 20-year relationship with the produce supplier Veritable Vegetable in favor of a larger California-based transport company. http://lamontanita.coop/wp-content/uploads/2016/09/Veritable-Vegetable-Message.pdf

${ }^{69}$ The perceived roles and (in)action of the Co-op's Board in these disputes has been written of in several sources: http://www.santafenewmexican.com/news/local_news/non-organic-produce-sparks-protest-at-lamonta-ita-co/article_636a970b-49b3-5505-b0cf-34c56b89a461.html; http://lamontanita.coop/wp-content/ uploads/2013/03/2016_04_19-BOD-Meeting-Minutes_APPROVED.pdf; http://inthesetimes.com/rural-america/ entry/19571/take-back-the-co-op-la-montanita-member-owned-cooperatives-new-mexico

${ }^{70}$ Though the petition at https://www.gopetition.com/petitions/petition-to-take-back-la-monta\%C3\%B1ita-co-op. html\# has garnered the required number of signatures, it remains active, though some demands have been overtaken by events.

${ }^{71}$ Election results on La Montañita's official page and on Take Back the Co-op's page corroborate the winners: http://lamontanita.coop/2016elections/; http://www.takebackthecoop.com/updates.html
} 
significant experience in various cooperative businesses sectors - have been deemed suspicious by Take Back the Co-op. ${ }^{72}$ They charge that - through its use of a policy governance model - CDS encourages co-ops to concentrate decision-making power in the hands of the GM under the rubric of operational issues over which the Board does not have a say. They see this as a conspiratorial strategy for usurping democratic processes, as the GM is not elected by the member-owners. ${ }^{73}$ Take Back the Co-op also sees CDS's advice encouraging the opening of the Westside storefront as the main source of La Montañita's current financial difficulties, as that location has operated at a loss since opening in 2013. NCG and CDS both have publicly challenged how Take Back the Co-op has characterized their work. ${ }^{74}$

Though it is difficult to parse all that has happened, La Montañita has tried to actively address the larger strategic complaints of Take Back the Co-op, as the proposed plans of this group to replace the senior management and GM, terminate certain business relationships, restructure Board processes, and close the Westside location would have seismic impacts on the way the Co-op runs as a multi-million dollar business with nearly 300 employees. The Co-op has held multiple community information sessions - several of which have been video recorded and posted on its YouTube channel - released more detailed financial information than usual; ${ }^{75}$ and put up fact sheets and posts with corrective or clarifying information. ${ }^{76}$ As indicated in its December 2016 Co-op Connection newsletter, it seems that La Montañita will challenge the authenticity of the signatures calling for a Special Meeting that would implement staff, management, and Board changes that are called for by Take Back the Co-op's petition. As of this writing, indications are that the situation is far from resolved.

\footnotetext{
72 The petition items about CDS and NCG question their relationship and financial arrangements with La Montañita. It also questions the practice of CDS hiring consultant staff who were Board members of co-ops they advised. https://www.gopetition.com/petitions/petition-to-take-back-la-monta\%C3\%B1ita-co-op.html\# ; http:// www.sfreporter.com/santafe/article-12485-nothings-wrong-with-the-co-op.html

${ }^{73}$ Take Back the Co-op describe what they see as a manipulative effort by CDS to homogenize food co-ops in "A National Takeover... One Co-op at a Time" http://www.takebackthecoop.com/corporate-takeover.html

${ }^{74}$ While NCG has posted a statement on its own web site, CDS has responded in a letter reachable through La Montañita's web site. http://lamontanita.coop/wp-content/uploads/2016/09/CDS-CC-Response-to-TBTC.pdf; https://www.ncg.coop/newsroom/ncg-responds-santa-fe-based-take-back-co-op-campaign-claims ${ }^{75}$ From the 2016 Annual Report of La Montañita http://lamontanita.coop/wp-content/uploads/2013/03/2016Annual-Report.pdf

${ }^{76}$ A separate page of La Montañita's web site has aggregated sources online to address and refute claims made by Take Back the Co-op and its plan to change the leadership. http://lamontanita.coop/40yearsdocuments/
} 


\section{8: La Montañita through the lenses of embeddedness and diverse economies}

I offer some reflections on how embeddedness and diverse economies appear at La Montañita Co-op. Though I do not presume that a single typology of embeddedness exists or is even desirable, the following descriptions undergird an understanding of La Montañita as engaged in relations of exchange that are beyond rational choice models of economy. In explicating some manifestations of this, one can see the utility of embeddedness in helping to show what is going on in the Co-op as more than a capitalist economic enterprise.

\subsection{1: Embeddedness}

Social embeddedness that has been described by Feenstra's (2002) use of "community food systems" requires an allowance of political, social, and intellectual space that helps build social capital and connection. The Earth Day Festival sponsored by La Montañita is the largest such festival in the state, attracting over 20,000 visitors each year with a variety of vendors, musical and cultural performances, and exhibitors from community, political, and environmental groups. By sponsoring a host of community initiatives (such as for Earth Day and its Annual Member Meeting), La Montañita has established itself as a community fixture that is not just associated with food provisioning but also with celebration. Additionally, its Volunteer Program, which offers shopping discounts for people volunteering in the community, emphasizes La Montañita's support for the cooperative principle of concern for the community. In so doing, the Volunteer Program encourages people to participate in their community in ways they otherwise may not.

La Montañita exhibits vertical and horizontal embeddedness in the vein described by Bowen (2011) through its representation and involvement in community and political groups. This includes advocacy work on governmental and regulatory structures affecting local food provisioning. During fieldwork, this was particularly evident at the time when the USDA was seeking public comment on the Food Safety Modernization Act (FSMA) and its potential effects on small farmers and those in short food supply chains. For example, through its participation in meetings of the Agricultural Collaborative, La Montañita helped raise awareness to get small producers and family farmers to participate in the consultation around FSMA. Additionally, La Montañita began to encourage its vendors to create food safety compliance plans based on FDA and USDA guidelines. This served both the Co-op and the supplier by prompting the adoption of procedures that would be required 
under FSMA, as well as encouraging local food suppliers to think about internal food safety practices.

Ecological embeddedness as described by Penker (2006) is reflected in the use of the "local" label for fruit and vegetables sold by the Co-op that are presumed to be produced using mainly organic practices: organish, one might say. While these non-certified products cannot be called organic, the pesticide-free and low-impact agricultural techniques used to cultivate them echo the underlying principles

\section{Advert 5: CDC leaflet for Tamaya Mill}

\section{Tamaya Organic Mill}

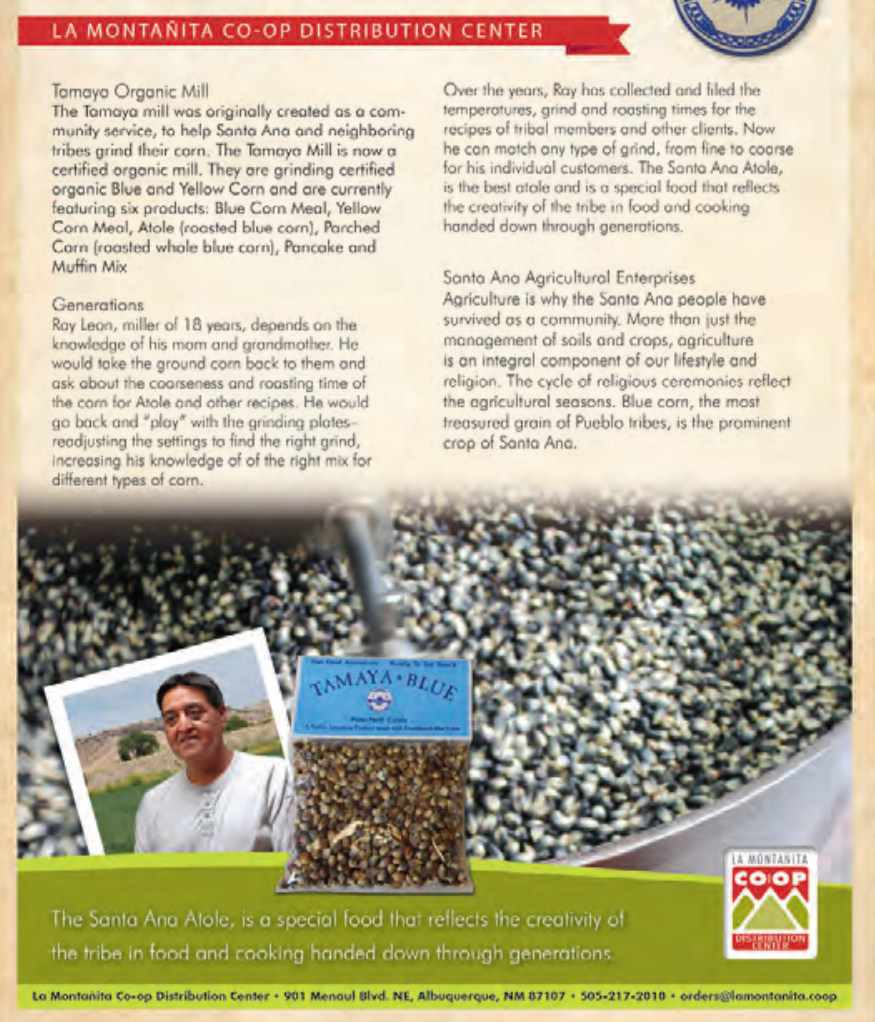

Image courtesy of La Montañita Co-op of ecological stewardship that are embodied in certified organic prod u c t i o n . Furthermore, in questioning the propriety of some practices allowed under the USDA organic program, the Co-op has also posited the idea of higher standards of organic cultivation than USDA certification would require. Notably, the social processes of relationship building between La Montañita produce managers and noncertified organish farmers demands significant communication, trust, and relations of regard that Penker described as interlinked with the spatial and ecological contexts in which they develop. 
With respect to socio-material embeddedness in the manner of Roep and Wiskerke (2010), an example lies in La Montañita's work with the Tamaya Mill. The Tamaya Mill is run by the Santa Ana Pueblo to bring new products to market that reflect the customs and knowledge of generations of indigenous people of northern New Mexico. Blue corn is variety of maize that is particularly important to the Santa Ana, one of the 19 Pueblos or native tribes that remained after Spanish colonization. It is both an important everyday food (with particular uses and a different nutrient profile than white or yellow corn) and a key item used in their spiritual customs and religious life. Although blue corn was popular and already sold amongst the various pueblo groups - such as in the blue corn-based snack called parched corn - staff at La Montañita Co-op worked with the Santa Ana Pueblo to expand the marketing beyond the pueblo communities. The Co-op created branding and marketing materials showcasing the development of blue corn as an agricultural crop specific to the land and community, and as one that highlighted traditional knowledge passed down over time.

Additionally, Co-op staff saw an expanded opportunity for the Santa Ana Pueblo to get premium pricing by pursing USDA organic certification on their products and the mill processing itself. As the Tamaya Mill's products were already organically grown and processed, the Co-op essentially offered guidance and contacts in navigating the procedure. The Co-op also saw the value of connecting Santa Ana's products with players in the hospitality and catering industry. Through establishing a link between the Pueblo and Café Bon Appetit - the dining service provider at the Institute for American Indian Arts, a Santa Fe-based art and design college La Montañita helped establish another outlet for the Pueblo's product. The chef at Café Bon Appetit was then able to expand his menu offerings, incorporating blue corn and other traditional ingredients that reflected the culinary heritage of the student population, $70 \%$ of whom had a Native American background. This allowed further branding and a marketing distinction for a local product, as well as a culturally-relevant dining experience.

\subsection{2: The diverse finance and labor economies of La Montañita Co-op}

The different conceptions of embeddedness I have offered may help to explore the ways in which an economic enterprise can function within certain socio-material, institutional, and ecological contexts. Nonetheless, a deeper engagement in social reform à la Polanyi requires a purposeful examination of the economy as a space 
of agency and contestation. Returning now to the theory of diverse economies and recalling that it proposes a conception of economy "as a situated and diverse space of ethical decision making and negotiated interdependence with other humans, other species, and our environment" Gibson-Graham et al. (2013, xix), I consider how an entity such as a cooperative business might express itself as a diverse economy.

One of the aspects of the economy that Gibson-Graham et al. (2013) urge communities to reconsider is finance. They suggest that communities "reclaim finance as an enabler of futures not an end in itself that is liable to self-destruction" $(2013,161)$. Doing so addressees the need to invest for future generations as part of developing a community-based economy. For La Montañita, a key piece of their future development and ability to thrive is to ensure that their local vendors stay in business. In the interest of that, the Co-op operates a line of credit for pre-purchased products through the $\mathrm{CDC}$ for certain vendors and offers the La Montañita Fund (LAM Fund) to other local food producers. These are both examples of alternative finance options that the Co-op had made available to suppliers. These options are outside of the traditional banking system, which farmers and small producers often have a very difficult time accessing. Not only has the Co-op provided a practical avenue of finance to its suppliers, it has also successfully offered an outlet to its member-owners to participate in the process of financing small local producers. In this way, the Co-op has engaged its community members in thinking of themselves as part of the economy and able to influence how it works.

The acquisition of fresh produce at La Montañita is a study in diverse economies that can exist within a single organization. As was detailed earlier in this case study, the Co-op buys its fresh produce via the CDC and via the storefronts. The CDC aims to work with medium-sized producers who have made the decision to sell at least some of their product through the CDC. These farmers typically have more product than they can sell at a farmers' market or than is worth the time that would be needed to sell it. So they may sell to the CDC at a lower price point but in larger quantities that compensate for this. The CDC also tries to offer extra services related to delivery and marketing that these producers can use. At the storefronts, produce managers order at a distance from Veritable Vegetable. They also buy directly from individual farmers who have small quantities and may literally come by the back door. This has allowed growers of different scales and at different levels of professionalization 
to interact with the Co-op and to have a mix of income streams in building their businesses. In this process, the Co-op, particularly at the level of the storefront, can engage creative and alternative capitalist (or even non-capitalist) practices that allow a variety of producers to be part of a community-based economy.

It can also be said that the volunteer program run by La Montañita is a manifestation of a diverse labor economy, by its recognition of the contribution of unpaid - though not uncompensated - work to the economy and the community. This recognition is particularly evident because volunteers serve various community organizations of their choice, not the Co-op. Though volunteers can receive a discount for shopping at the Co-op for each volunteer hour worked, the community organizations where the volunteers serve actually benefit much more directly than does the Co-op.

\subsection{3: Case summary}

While there are certainly other food co-ops in the natural organic sector that are also interested in developing a local food economy, I did consistently hear feedback from people in the US food co-op world - that La Montañita was among the few doing exceptional work on this level. ${ }^{77}$ La Montañita has been engaged with different aspects of local food and community development projects to a greater degree than other co-ops. This notably includes financing of local food and developing local food businesses.

There is some tension with respect to the overall cohesiveness of the work around local food in the organization. (This might be ameliorated by hiring a local sourcing staff member, as called for in the original Strategic Plan, to better connect the stores' produce managers and the CDC.) There may be, however, a basic disconnection in scaling up quantities of local food - as called for by the Strategic Plan - with how produce sourcing is generally done by the Co-op's storefronts. There seem to be some divides between storefront and CDC employees (and also between La Montañita and its vendors) around pricing. Better communication of the overall ethos and goals of the local food provisioning operation is important. This is apparently done better in some areas of La Montañita Co-op than in others.

For interview respondents, regardless of how they might think of local food abstractly, understandings of local food were mediated by the work have to do

\footnotetext{
77 Another evidently prosperous (and larger) cooperative local food system can be found in the Twin Cities area of Minnesota. See http://www.crcworks.org/tccoops.pdf for details.
} 
in their job and function. La Montañita has assumed various roles in creating a community food system, not just functioning as a food retailer. La Montañita has to be able to serve many stakeholders - both customers and local producers. It is difficult to address immediate concerns about keeping the right stock on shelves at the right prices while working to make a more sustainable food system. Going beyond practicalities, though, for some La Montañita employees, there remains a great deal of ideology and purpose around local food. 


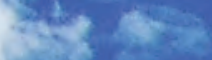

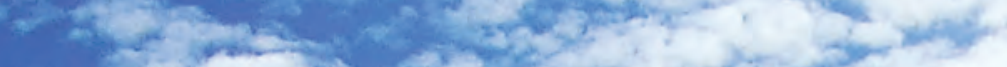

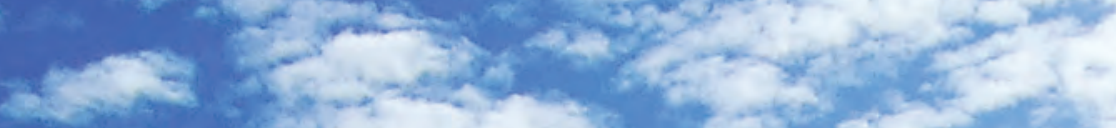

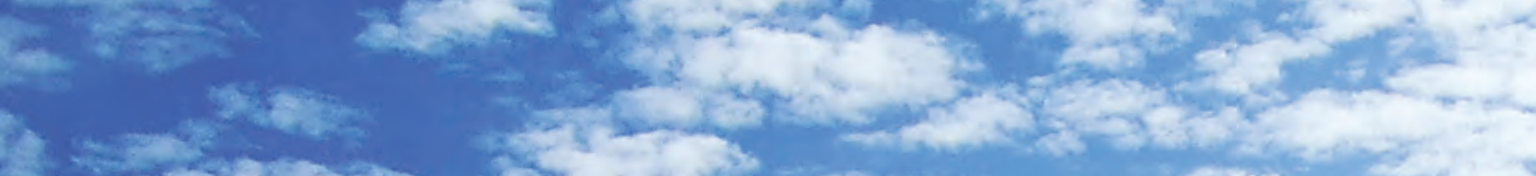

$x^{-1}+\frac{6}{2}$

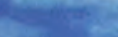

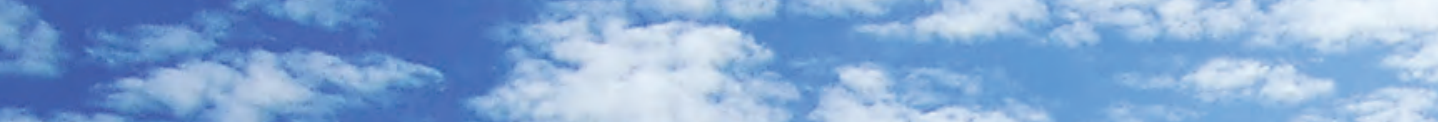

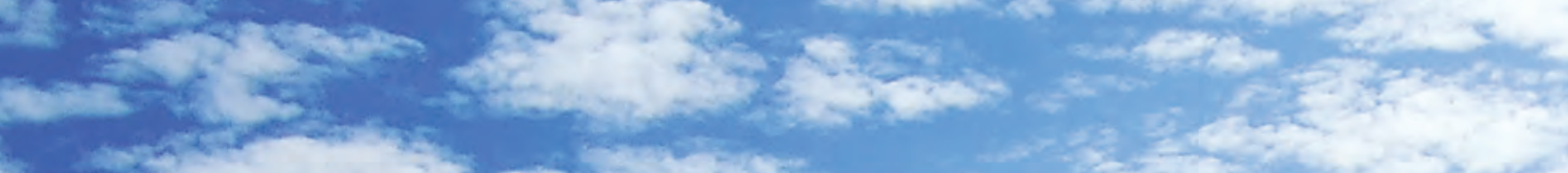

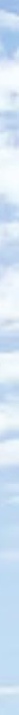

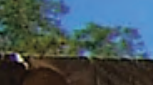

2 
This chapter introduces the smaller of the two case studies - that of Mountain View Market Co-op and Mountain View Market Farm based in Las Cruces, in the southern part of New Mexico. After describing this case, I offer a discussion of significant post-fieldwork changes at the Co-op and the manifestations of embeddedness and diverse economies.

\section{Chapter 5: Case Study of Mountain View Market Co-op}

Mountain View Market Co-op presents an interesting case as a successful co-operative that offers local and regional products in its retail shop and food service locations and also via a small farm. This includes fresh produce, meat and dairy products, shelf-stable value-added items (such as prepared sauces and baked goods), and health and personal care (such as soaps and cosmetics). Like La Montañita, Mountain View Market Co-op uses a definition of local as being within 300 miles of its Las Cruces, New Mexico location. As with La Montañita Co-op, I have used the same research questions and approach, which are reiterated below.

Research Questions

1) How do cooperatives frame local food?

a. What do the staff at retail food co-ops talk about when they talk about local food?

b. What do the staff at retail food co-ops say about local food?

This question refers to the perceptions and experiences of the staff of the cooperatives. I did not seek individual and household-level customers' perceptions and experiences of local food, as provisioning of local food is undertaken by employees, not customers. As such, consumer perceptions of local were beyond the scope of this research.

2) What are the practices that retail food cooperatives use to engage in local food?

Though listed as separate questions, these are in fact taken together in this chapter. This is because a central understanding of the use of framing is that an actor's definition of a problem or phenomenon shapes the actions taken to address that problem or phenomenon (Fenton and Langley 2011). As such, this chapter 
describes the development of Mountain View Market Co-op as an instrument for local food provisioning and takes into account the circumstances of its particular environment. Following an overview of the Co-op, I examine the framing of local food from interviews with staff. After this, I discuss the Mountain View Market Farm, which is the Co-op's particular embodiment of a strategy to directly and indirectly provide more local food in Las Cruces and its environs.

\section{1: Overview}

In Brief

Mountain View Market Co-op is a retail grocery shop in the natural and organic sector in Las Cruces, New Mexico, USA. It has one retail supermarket location and has changed name, location, and format several times - finally moving to its current location in a small shopping center in 1993. At the time of fieldwork, it occupied an 11,000 square foot retail and administrative space that also included a cafe area (called the MVM Kitchen) with seating and an assembly room (called the Community Room) available to local groups. An additional small coffee bar and cafe (called the MVM Downtown Kitchen) had also opened a mile from MVM Co-op but closed in 2015 after two years of operation. In addition to onsite sales, at the time of fieldwork, MVM Co-op also operated additional ventures beyond the store: an online ordering and delivery service and a 2.5-acre (1 hectare) demonstration and educational farm (called MVM Farm). Mountain View Market Co-op is also connected to the La Montañita $C D C$, receiving one delivery truck from them each week. As of 2009, MVM Co-op had 6400 members with approximately 3500 members actively shopping. Projected sales for that year were at $\$ 3.5$ million, with $67 \%$ of sales made to MVM members. There were more than 4000 active members by 2014 .

\section{Location and Geography}

The city of Las Cruces lies at the intersection of US interstate highways I-10 and I-25 and is about 225 miles (approximately $360 \mathrm{~km}$ ) directly south of Albuquerque on I-25. The route between these cities, despite being the state's main north-south link, has a very sparse population concentration along the way (fewer than 10 people per square mile). Las Cruces is situated in southern New Mexico very close to the state's borders with Texas and the country of Mexico. While Las Cruces is in the state of New Mexico, some of MVM's economic activity also happens in El Paso, Texas, which is 46 miles to the east of Las Cruces. Las Cruces is part of the El Paso-Las 
Cruces combined metropolitan statistical area $(\mathrm{msa})^{78}$ and shares significant social and economic ties and intersecting media and labor markets. The US Census also states similar 2014 median household income figures for Las Cruces, New Mexico

Photo 10: Mountain View Market Co-op storefront

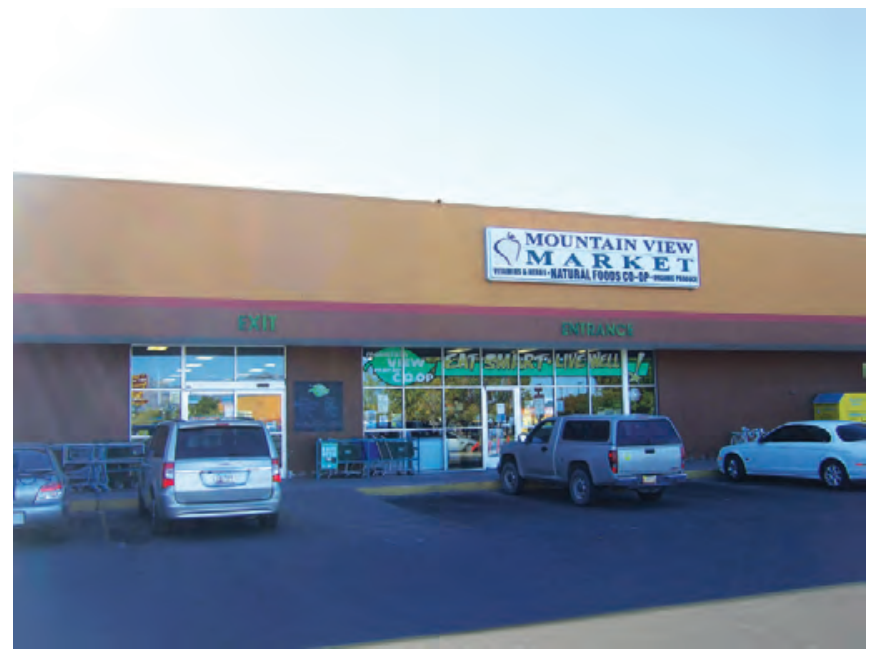

and El Paso, Texas $(\$ 40,658$ and $\$ 42,037$, respectively).

Las Cruces is the principle city of Doña Ana County, which lies wholly within the Chihuahua Desert ecoregion at an elevation of 3900 feet (1200 m). The Organ and Doña Ana mountain chains lie to the east and north of the city, respectively, while the Mesilla Valley forms the floodplains of the Rio Grande River running to the west of the metropolitan region. Though the entire state of New Mexico is an arid region, it has various microclimates, allowing production and husbandry of distinct plant and animal species. The arid lowlands where Las Cruces is located has also developed different agricultural practices and management traditions. For example, that region has the majority of confined animal feeding operations (CAFO) in the state and has more valuable farm operations than those in the northern part of the state. Doña Ana County had the highest valued crop production in the state in 2011, with the average net farm income of $\$ 57,075 .^{79}$ High value commodities grown for export included alfalfa, cotton, chili (chile) ${ }^{80}$ peppers, and pecans.

\footnotetext{
${ }^{78}$ While an msa is not a legally defined administrative district, the term refers to adjacent metropolitan areas defined by the US government and used in census and statistical purposes.

${ }^{79}$ Data come from a 2011 report by the New Mexico office of the US Department of Agriculture statistics service, which periodically surveys the New Mexico agricultural community. http://www.nass.usda.gov/nm

${ }^{80}$ Both the US American and international spellings may be used in reference spicy cultivars of genus Capsicum where found in this work.
} 


\section{Business Climate}

MVM Co-op has a somewhat unique place in the Las Cruces retail food environment because of its focus on natural and organic products. Las Cruces - though the second-largest city by population in New Mexico (approximately 101,000 people) had not attracted branches of the major national or regional organic sector stores such as Whole Foods. ${ }^{81}$ One competitor with a single shop called Toucan Market has some overlap in products but is focused on specialty cheeses and offers wine and spirits. At the time of fieldwork, MVM did not have a liquor license to sell alcohol and is thus less able than Toucan Market to cater to the University of New Mexico campus located nearby. Despite the advantage it would offer, the liquor license cost $(\$ 500,000-800,000)$ was considered prohibitive to MVM Co-op. Rather than natural and organic shops, Las Cruces boasts three Wal-Mart Supercenters and several branches of the Albertson's supermarket chain, both carrying mainly conventional (non-organic) products, and where low prices are a main attractor.

MVM purchases much of its shelf-stable grocery items (i.e. items typically located in the center aisles of supermarkets) from UNFI (United Natural Foods, Inc.) - the leading distributor of natural and organic food products in the US - at a discounted rate. This is because MVM has a buying contract ${ }^{82}$ via its membership in National Cooperative Grocers (NCG), formerly the National Cooperative Grocers Association (NCGA). This contract requires member co-ops to purchase most of their grocery items through this contract, with discounts based on quantities purchased. The contract requirement has not especially hampered MVM's ability to source locally, as the outside aisles - where fresh products such as dairy, cheese, and produce are carried - offer the most opportunity for local offerings.

MVM Co-op is also a founding member of the Green Chamber of Commerce for Las Cruces. The Green Chamber's members are all locally owned businesses with an environmental ethic and a self-avowed commitment to triple bottom line practices. MVM established a program to further support and advertise these and other locally

\footnotetext{
${ }^{81}$ At the time of fieldwork, a competitor was slated to enter the market in the coming months. Natural Grocers, based in the bordering state of Colorado, sells nutritional vitamins and supplements (40\%) and natural and organic food and cleaning products. The shop opened in April 2014.

${ }^{82}$ NCG is a business services co-op with 143 members (including La Montañita and Mountain View Market) in the natural and organic foods retail sector. A main component of their work is leveraging purchasing power and operational and marketing resources for its members. This includes the creation of a buying agreement with UNFI that allows co-ops agreed-upon competitive pricing on a large number of grocery items, enabling NCG members to be viable in the market place. NCG members participating in the contract receive specific discounts for volume purchases and agree to make UNFI their primary distributor for certain items.
} 
Photo 11: Banner promoting independent businesses giving special offers to MVM members

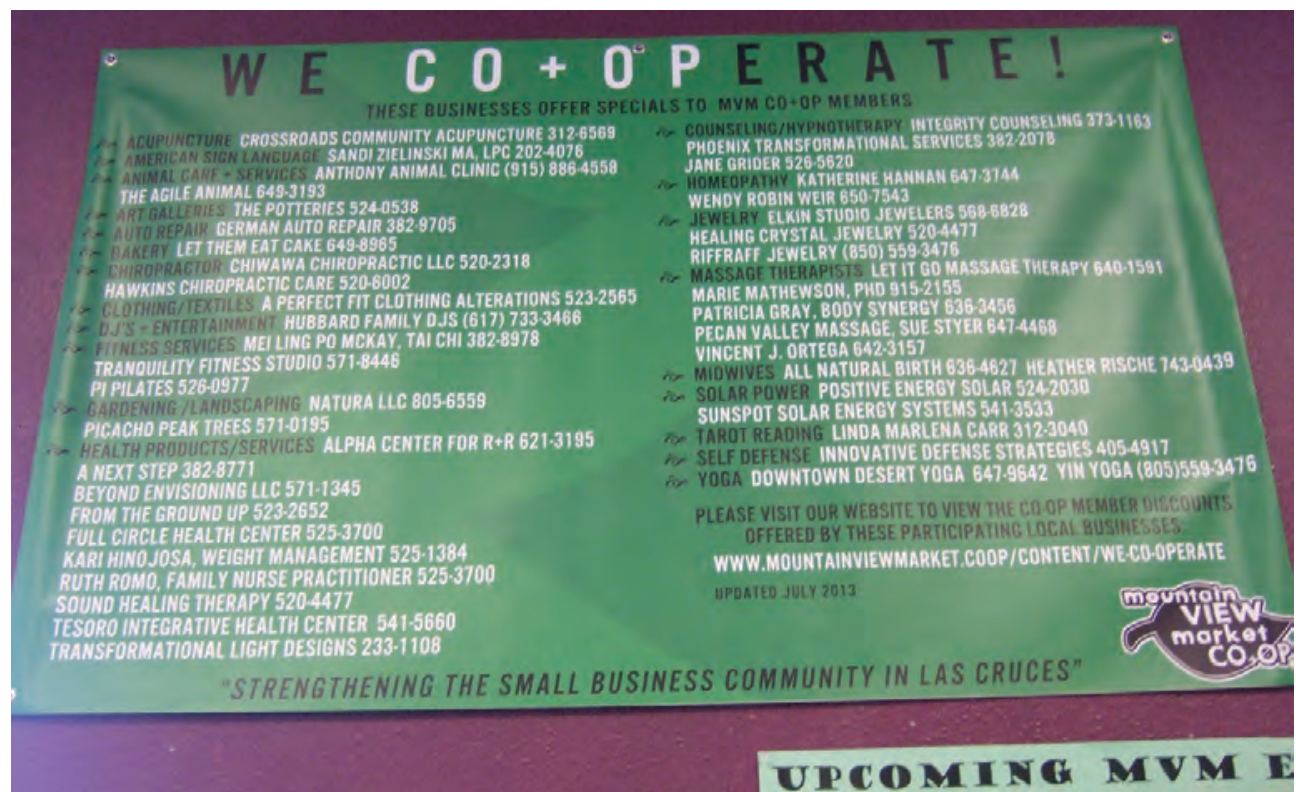

owned businesses through their "We Cooperate" initiative. In this program, MVM Co-op members receive discounts and special offers at participating businesses, many of which are also institutional customers of MVM Co-op or MVM Farm.

\section{Cooperative History}

Students from the New Mexico State University established the Mountain View Market Co-op (MVM) Co-op as the Organ Mountain Cooperative in 1975. The students were interested in collectively purchasing and distributing products they could not easily or otherwise get in that part of New Mexico. This included "health foods," whole grain foods, and specialty beverage products. They purchased products from a natural and whole foods distribution operation in Tucson, Arizona 274 miles (441 km) away and soon found that the scale of their operation worked better in the form of a retail shop than as a buying club with selected pick-up points. The first shop was founded in a disused fitness center, and anyone was able to shop without being a member of the Co-op. There were two levels of discounts available to members who worked at the shop on various tasks, depending on the frequency and number of hours of service provided. 
In 1993, and with a great deal of help from its members, MVM Co-op moved from a 3500-square foot space to its much larger present-day location in the Idaho Crossings shopping center on a street running between two major highways (I-10 and I-25). This new location offered upgraded spaces, safety-compliant equipment, better storage and preparation facilities, space for community use, a dining area, and hot and prepared foods counter. Because the previous location was within walking distance, much of the move was done via shopping cart, with the members and volunteers pushing goods between the old and the new shop. Various renovations to the new space, including painting and decorating, were also accomplished with physical labor contributed by the MVM community.

Photo 12: Wall mural of cooperative principles at store manager desk

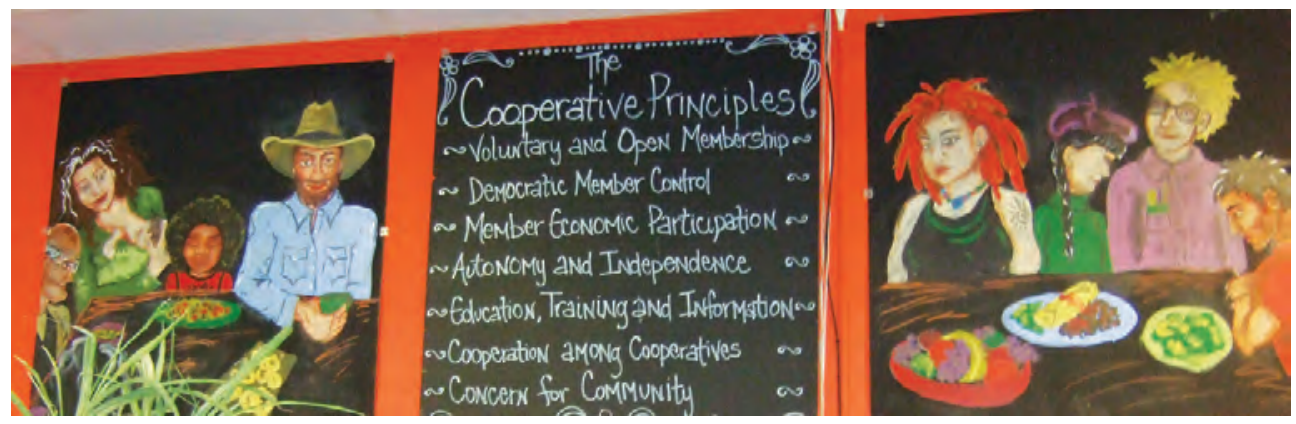

\section{2: Mountain View Market, organizationally speaking}

MVM Kitchen and Downtown Kitchen

With its move to the Idaho Crossings shopping center location, MVM Co-op created a "Grab \& Go" department offering fresh salads, house-made sandwiches, and cookies and muffins available in a refrigerated case. The Co-op then added to this a full-service production kitchen with made-to-order hot and cold sandwiches, salads, smoothies and juices, and seasonal daily soups. The seating area was expanded to accommodate approximately 30 customers, and free Wi-Fi Internet was installed. This both drew customers and made the space more inviting and useful to local groups having meetings in the community meeting room, which the Co-op wanted to encourage. The MVM Kitchen also does catering for store and private events. The Downtown Kitchen was in a smaller space with essentially the same menu as the MVM Kitchen and with staff rotating between the two Kitchen locations. 
Map 6: Mountain View Market locations A) Co-op, B) Downtown Cafe, and C) Farm

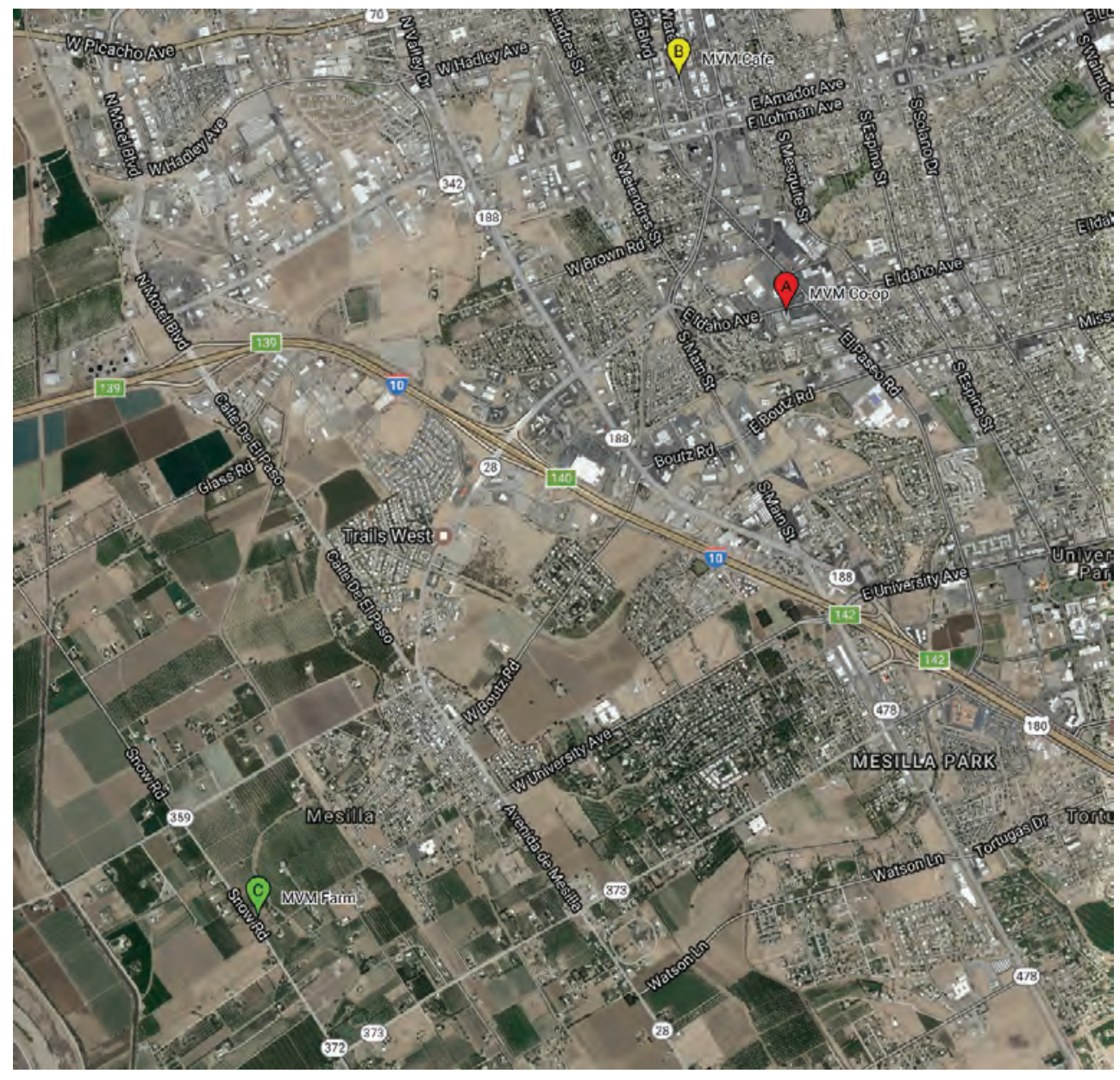

Source: Google Maps, elaborated

\section{MVM Farm}

In 2011, the Co-op leased a 2.5-acre property that became the site of the Mountain View Market Farm, a non-certified organic farm that incorporates permaculture, aquaponics, and small-scale animal husbandry. The original aim of the farm was two-fold: to grow (non-certified) organic produce for sale in the MVM Co-op and at local farmers' markets and to provide training to local producers growing organically in order to expand local food production. At the time of fieldwork, the Farm employed three staff members (the farm manager, the farm assistant, and the farm administrator), all women who had strong social networks in Las Cruces. 
The MVM Farm uses a significant amount of volunteer labor from high school and university students and from community groups. The Farm does a lot of outreach and education with these groups mainly through school-farm visits. The MVM Farm has heretofore been financially subsidized by the Co-op and overseen by the Co-op's Board. The Farm's future plans would see the recruitment of its own separate board and changes in its organizational structure that could lead to its self-sufficiency and financial independence from the Co-op. This would mainly be through conversion to a non-profit organization; having such status would offer expanded grant funding opportunities from educational and community development donors.

\section{Staff}

MVM Co-op had 41 total staff members at the time of fieldwork, with 27 of those working full-time. The Co-op offers what they call a "living wage" (\$8.72), higher the federally mandated minimum wage (\$7.25) and the New Mexico-mandated minimum wage (\$7.50). ${ }^{83}$ MVM uses a system called Open Book Management that encourages transparency of business operations and cultivates responsibility for the success of a business amongst all levels of employees at an enterprise. All new employees (except those on the MVM Farm and Kitchen) are trained in every department and are hired for (or must work) shifts attending the cash registers. This is to allow for maximum staffing flexibility for the Co-op, a broad knowledge of the shop's workings, and customer service experience for all staff members. The age range of the staff was rather young at the time of fieldwork. The GM, though only in his early 40s was one of the oldest people on staff, including throughout higher management positions. Similarly, the average length of service to the Co-op was fewer than 4 years.

\section{Membership and Governance}

MVM Co-op ownership shares are sold in $\$ 20$ increments, with the cost of a full share at $\$ 205$ (as of 2013). A member becomes a lifetime member once accumulating a "balance" of $\$ 205$, either paid all at once or paid in uninterrupted increments paid annually over the course of 10 consecutive years. Members have access to special pricing and sales, discounted admission to workshops (both at the farm and for those offered by the community groups using the community meeting room), and voting privileges at the Annual Member Meeting held each April. Members also receive a patronage rebate based on calculations made each year by the Board and

\footnotetext{
${ }^{83}$ The hourly wage figures listed in this paragraph were correct at the time of field work.
} 
depending on the store's profits. Members are encouraged to attend the Member Forum portion of the monthly Board meetings. This portion of the meeting is expressly set aside to hear feedback from the membership about all issues.

Though the Co-op has always been consumer-member owned, an administrative group of three people initially managed the Co-op. It was not until 1980 that MVM established an elected Board of Directors chosen by the membership. Today, the MVM Board comprises 10 members, including an allotted employee member position. Board members, who can serve a 3-year term and a second consecutive term, must be Co-op members. The Board committees are all ad hoc (save for ongoing, specific work). Like La Montañita, MVM Co-op also uses the Carver Policy Governance model, which encourages the creation of a mission statement (called an ENDS policy) that guides the direction of the Co-op. The ENDS for Mountain View Market Co-op are the following:

1) The community benefits from outreach, support, and education.

2) The Co-op provides information and access to healthy food and health products.

3) The Co-op models sustainable living.

4) The Co-op reflects inclusivity and diversity.

5) The Co-op is a viable alternative economic model based on cooperative principles and values.

6) The Co-op supports local and regional production and encourages a diverse food system.

The cooperative ethos has reportedly been very strong at the Co-op from the start: "A poster from [the 1980s] reads: 'A Store with Character: Where Mutual Aid is More Important Than Profit, and Each Member is an Owner...' The poster also boasted pot luck dinners, herb walks and other programs that reveal an involved membership." 84 The membership also continues to support a variety of activities that build the Co-op community and the Las Cruces community at-large, with support of community festivals, women's empowerment groups, soup kitchens and food banks, and specific charity activities for children with nutritional issues.

\footnotetext{
${ }^{84}$ This is described at http://www.mountainviewmarket.coop/blog/2015/6/23/the-history-of-mountain-viewmarket-co-op
} 


\section{3: Local food provisioning}

The Growers' Market

Though the MVM Farm represents the Co-op's most substantial engagement with local production, the Co-op is supporting local food provisioning in other forms. The Co-op had purchased locally grown produce for years from local gardeners, but it established a more concerted effort to connect growers with the public in 2008 by starting a farmers' market in its parking lot. During the spring and summer months, the Co-op hosts this "Growers' Market" each Sunday. The market serves as a sales outlet for local farmers and gardeners in an effort to promote and support local food production. Sellers at the Growers' Market pay a nominal fee (\$2.00) for a booth and have reported that it is a valuable service to them. In 2013, however, the Growers' Market was cancelled for the first time in six years because of poor yields or participation. This was due to the heavy and ongoing drought affecting the area and diminishing small-scale production.

\section{Kitchen Procurement}

The Kitchen at MVM Co-op has a strong interest in local food and an active engagement with customers about the products used there. The Kitchen Manager who came on staff in 2009 developed an ethic of seasonality and using local ingredients, many of which are sourced from small businesses in and around Las Cruces and El Paso. Products sourced include bread and pastries from local bakeries, coffee beans from local, independent roasters, and fresh produce from the MVM Farm. The meats used in the Kitchen come through the La Montañita CDC local meat program, and over $80 \%$ of the cheeses on offer are from New Mexico. In 2013, purchases from local sources accounted for over $27 \%$ of total food purchases for both Kitchen locations.

\section{Online Ordering and Delivery}

Customers outside of Las Cruces typically drive from 40-75 miles to shop at the Co-op. This presents a conundrum when it comes to the sustainability of local and organic foods offered by MVM, if customers also drive long distances to buy food. In recognition of this and the potential attendant opportunities, MVM Co-op has an online ordering service to bring local food and organic products to several of the more isolated communities that may not be able to access such food at all. This allows the Co-op to expand its reach and customer base and provide what it sees as a service to outlying communities in southern New Mexico, which has a much sparser population 
density than the north. These small cities include Truth or Consequences (75 $\mathrm{mi} / 121 \mathrm{~km}$ ), Alamogordo (68 mi/109 km), and Deming (61 mi/98 km). Additionally,

Advert 6: MVM Co-op's delivery service to other New Paso, TX, which-though Mexican cities and to El Paso, Texas
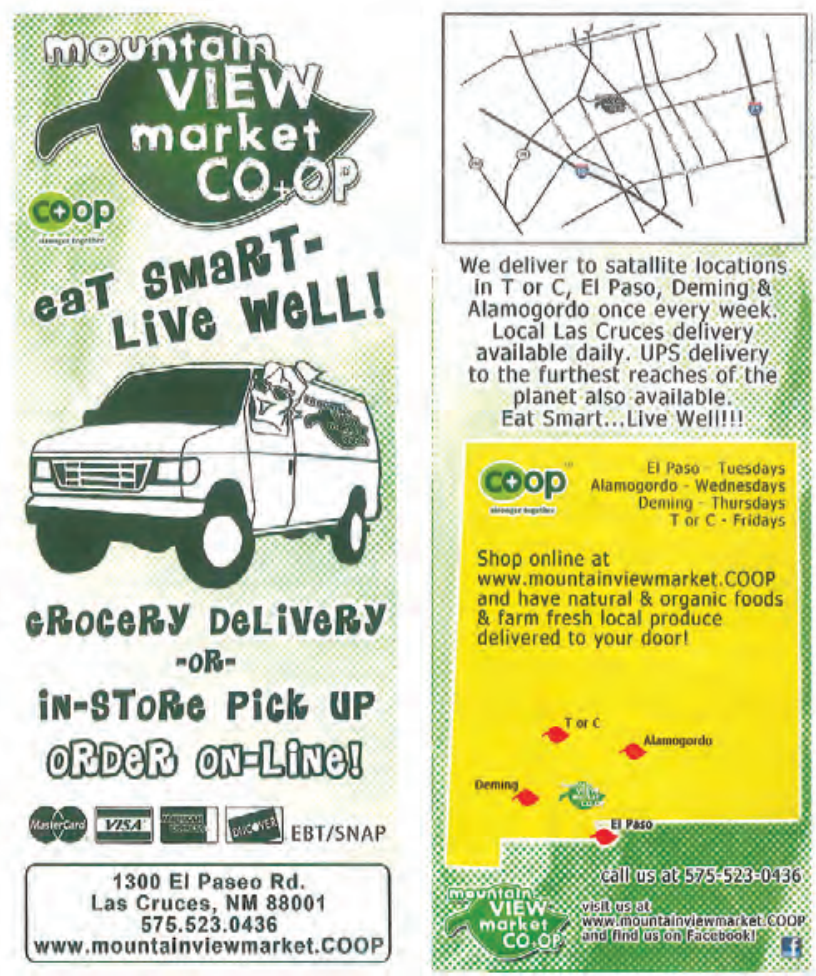

in the state of Texas - is only $46 \mathrm{mi} / 74 \mathrm{~km}$ away).

One employee collects orders and makes deliveries, while a consultant manages the web site remotely. Home delivery within Las Cruces (or at one of several drop-off points in town) costs $\$ 7.50$ in addition to the order. There is a charge of $\$ 0.55$ cents per mile for delivery to El Paso, Alamogordo, Truth or Consequences, and Deming - with some minimum order amounts required. Customers can order almost everything in the store via the website (moderated by the zip code). The delivery van is refrigerated, so cold storage items can also be delivered. Through buying clubs in these communities, small groups are thus able to take advantage of bulk pricing and avoid costly and unnecessary automobile travel. Local businesses are also able to act as drop points for people ordering individually but willing to go shorter distances to collect their Co-op orders from other shops. This may also help bring in new customers with whom they would otherwise have had no interaction.

In addition to delivery orders from the Co-op, the Co-op delivers farm share boxes to customers in El Paso from both Skarsgard Farms (an organic CSA based in Albuquerque) and from the MVM Farm. The MVM Farm boxes - which customers 
can order through the Co-op's web site - are either delivered to El Paso or made available for pick up at the Co-op. The MVM Farm boxes are not available for home delivery within Las Cruces. Customers receiving the Skarsgard Farms CSA boxes can also order additional products from the Co-op to be included in their delivery. MVM Co-op also offers limited mail and courier service that allows products to be sent all across the US. For a pre-arranged price, customers can order many special, regional items (such as green chile peppers, local salsa, and other prepared products) to be sent to them.

\section{4: Framing local food at Mountain View Market}

What is good food?

Mountain View Market, like La Montañita Co-op, has policies on the type of food it considers fit for sale in its shops. All the produce offered for sale must be organically produced, even if not certified as such. The Co-op uses three classifications to label produce. There are special signs and shelf labels that distinguish each of these categories in the produce section.

- Organic produce is certified organic through the USDA Organic program via an accredited organic certification body. This produce comes mainly from their distributor Veritable Vegetable in California.

- Local is a trust-based classification that the Co-op uses for products from uncertified growers that purport to produce food without synthetic fertilizers, pesticides, herbicides, or fungicides. (This label is also only used for produce. Shelf-stable grocery items have no "local" store labels but may indicate a place identifiable as local on their packaging.) While there is some degree of vetting of local producers at the time they first become suppliers, there is no defined and ongoing inspection regimen. A Co-op staff member tries to do a farm visit (rather than an inspection) once per year. MVM uses a 300-mile radius from Las Cruces, though items coming from Mexico through an organic distributor are not labeled as local. ${ }^{85}$

- MVM Farm specifically denotes produce that comes from MVM Farm. The Farm harvests twice per week for the CSA boxes, the farmers' markets, and the Co-op's produce section.

\footnotetext{
${ }^{85}$ Occasionally, Co-op staff used the term "regional" when speaking about local food coming from within 300-miles from Las Cruces.
} 


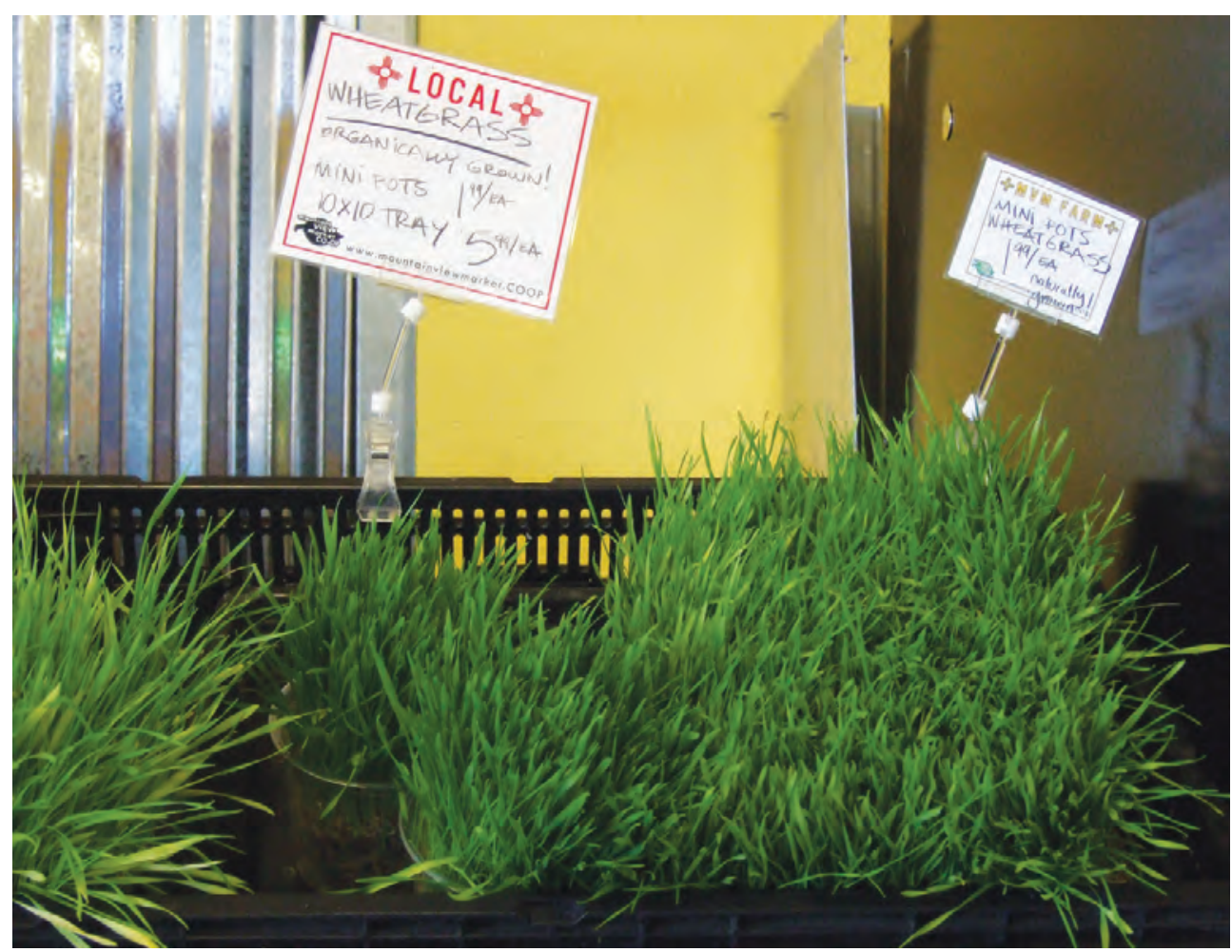

For the convenience of customers needing a gluten-free diet, the Co-op labels such products with orange shelf tags. The Co-op also labels packaged products with a rating scale called "HowGood," an appraisal system developed by a national company that works with many retailers and has evaluated more than 137,000 products. HowGood offers a third-party evaluation system measuring environmental impact, social responsibility, and product integrity. The Co-op also features products that are certified by other third-party labels, such as those that are fair trade or GMOfree. 


\subsection{1: From food access to food security ${ }^{86}$}

Though these valuation systems are relatively recent, the Co-op understands - as part of its own creation story - that consumers have had difficulty in finding proper, healthy food for a long time.

"I will say from the very beginning, it was always about access. It was always about access to good food. As we were started by New Mexico State University students, that was part of their mission. They wanted affordable, good food, and they were seeing (even in 1975) that the quality of food was being compromised, as large-scale agriculture was starting to dominate. Things that they wanted -- whole foods, whole grains, clean food, were less and less available." - GM, MVM Co-op

Quality food, as understood by the Co-op, means organic or low-input agriculture that became increasingly scarce because of agriculture's focus on large-scale commodity growing in that part of New Mexico.

"We know that, historically, we've been able to produce food in this region, and due to the growth of agribusiness, a lot of the production has switched over to commodities. We produce more cotton and alfalfa for feed, corn for feed and perhaps fuel... than we do of actually [sic] food that could feed the community. So our approach was to develop a relationship with local producers and start to source from them." - GM, MVM Co-op

Mountain View Market Co-op did not have as much of an articulated strategy for engaging with local food as did La Montañita, though it clearly has a deep interest in supporting its development. Though the Co-op had been purchasing food from small farmers and gardeners since its early days, the 2006-2008 economic crisis, with its attendant increases in food and fuel prices brought urgency to the activities surround local provisioning.

"What we realized is that we import from California a lot of the food that our customers demand, and that's always been the case ... but back in 2007, as

\footnotetext{
${ }^{86}$ The assertion of the need for food security in this region of New Mexico primarily came through several interviews with Shahid Mustafa, the General Manager in post during fieldwork. He had held that position for eight years and moved to Las Cruces for the position, having had years of retail food co-op experience on the east coast of the US. Though some staff in interviews also discussed food supply issues as food security, I was unable to get access to Board materials, newsletters, or Co-op documentation that would similarly express sentiments in that way. Mr. Mustafa was very influential in the formation and growth of MVM Co-op and other staff members (including the employee Board member) praised him highly for the many initiatives he started or further developed, both with respect to local sourcing and the general running of the Co-op.
} 
we started to see the oil prices increase, we really started to realize the impact of that on food. ... Being in a historically agricultural community, we found that there was this great opportunity for us. If we start to source from local producers, we'd be in a much better position in the long run." - GM, MVM Co-op

Because MVM's main organic produce distributors (based in California and Colorado) charge extra fees for delivery associated with fuel and distance, being so far from the source and importing food was financially burdensome on the Co-op. The additional cost burden from increased prices also highlighted awareness that the Co-op was dependent on being a worthwhile market for its suppliers: "I think it's beyond security for us, because it's not a matter of us not being able to afford it. We are afraid that it will get to a point one day where it's just too expensive for them - no matter how much we're willing to pay - it's just not worth it for our current sources to deliver to us." - GM, MVM Co-op

The Produce Manager echoed this sentiment in relating how important it was that their produce supplier Veritable Vegetable began (since the previous spring) to deliver to the Co-op three times per week. She described this development as "a real coup," because prior to this, deliveries were only coming twice per week. This meant that the produce did not look very fresh or appealing to customers after a number of days.

"... by the weekend, our produce looked really sad. ... So we finally got them to give us a third truck. Now it's every other day. We get fresh stuff. It's always kind of a threat. [I'm] like really nervous that we're going to lose that truck if we don't make our orders bigger. We almost lost that third truck, but I told them it's made such a huge difference in our sales. ... they were really great, and they worked out a way for us to get that third truck, even though they're taking a little bit of a loss." - MVM Produce Manager

The need to maintain positive relationships, such as is done with Veritable Vegetable, further highlights the precarious nature of sourcing for the Co-op. This extends to shelf-stable grocery, as well as produce. Although MVM Co-op is able to get most of its grocery stock (upwards of 60\%) from UNFI, the Co-op GM also sees the threat of its dependence on it.

"... we really need to start thinking about autonomy because we don't own UNFI. ... It's not a cooperative, and it has stockholders. It could be owned by 
somebody who just decides: 'Hey, I really want a part of this business. I'm going to buy UNFI, and I don't necessarily care about this relationship with co-ops. I really want to work with Wal-Mart. That's where the opportunity is.' So I think we always need to be thinking about that."

\subsection{2: Growing farmers to grow food}

Times have been difficult for low-input small-scale farmers in New Mexico, partly due to an extended drought lasting over a decade, which may be said to be the new normal for that part of the world. The Co-op saw a lack of available local organic produce (whether certified or not) leading to the market not being adequately served with enough product and to high prices excluding those on lower incomes. The Co-op initiated some informal conversations with local growers to find out what their needs were in order to stabilize and help increase production. Production increases were seen as necessary not just to help supply the Co-op with local food, but also to make local food more economically accessible to more people.

In the consultation process, it became clear that there were multiple challenges in local food provisioning. One of those things was cold storage, which was needed to extend shelf life and give them a chance to sell either to the Co-op or at farmers' markets. The harsh climactic conditions and temperatures meant that, once harvested, produce would be saleable only for a brief period of time without cold storage. To that end, the Co-op provided a 400-square-foot, refrigerated shipping container (nicknamed the Beast) for local farmers. The Beast was "parked" at the back of the Co-op's property, and local farmers could drop off their produce to be sold at the Co-op, delivered in CSA boxes, or held for the La Montañita CDC trucks doing backhauling. Still, producers also explained that - without having refrigerated transportation from their farms to the Co-op - they were limited in their ability to make use of the Beast.

\subsection{3: Local producers' needs and education}

Through the consultations, producers also expressed the need to have guaranteed prices to make harvesting worthwhile and to more deeply engage with local provisioning. This issue of pricing, however, proved to be more complex for the Co-op to address with their local suppliers. At the time of fieldwork, MVM began to develop a cost worksheet to help producers determine appropriate pricing. This is because farmers routinely did not know what kind of pricing they actually needed to make their participation in local food provisioning worthwhile. Growers would 
consistently tell the Co-op that they set their prices at what the market would bear. In reality that meant looking at what other farmers or what stores were selling the same products for and using those figures as a pricing guide - regardless of the actual costs of their own inputs. "I can't just say: 'Hey, this tomato is going to be 50 cents a pound because the guy across from me is selling tomatoes for 55 cents a pound.' That's what people would do, and there was no way to measure it. All of their data was in their head." - GM, MVM Coop

This also had an effect on how the Co-op was able to interact with growers wanting to supply the produce department of the shop. As the produce section sought to improve their operations, they wanted to continue buying from backyard gardeners and others where possible, despite making a smaller margin on local produce than they would on produce from California. In this way, local produce is less profitable to the Co-op.

\begin{abstract}
"You know, I want to give them a fair price, and they seem like they're really struggling. They usually want more. It's hard to explain: I want to support you. I want you to get the best possible price you can get. I really do, but I also want that thing to sell, too. It's really hard. Sometimes I almost feel like I'm pulling numbers out of thin air, and I wish that growers came to me more often and said: "This is what it costs for me to grow it, and this is what I need for it. And I could just say yes or no, instead of me trying to figure out some number that they might sell at." - MVM Produce Manager
\end{abstract}

Indeed, pricing was part of a larger set of concerns regarding the business acumen of their suppliers. The Co-op wanted growers to have a better understanding of market segmentation and the needs of individual and institutional customers outside of the farmers' market setting. Growers might not recognize that supermarket customers have different standards for what they will buy in a shop, versus what they will buy at the farmers' market. Communicating this without alienating growers has proven tricky to the produce section staff, but providing advice on this issue has been crucial.

"We have learned that there's some sort of weird psychological thing that happens a grocery store. Like you might see some kind of exotic weird vegetable at a farmers' market. It's like \$5.00, but you're like “Ooh let's try it!" But if you saw that in a grocery store, you'd walk right by it. ... It's like they have a different set of expectations at the grocery store. ... And it's hard. I think 
maybe they get offended. I can understand. They put their heart and soul into some beans, and you're like "Oh, no. It's not going to sell. Oh, no." I don't mean to sound harsh. ... I just know from working here for 4 years people just don't buy tomatillos. They just don't. They're gorgeous, but just save them for the farmers' market." - MVM Produce Manager

Similarly helping growers to understand the needs of institutional customers (i.e. restaurants and cafés) has been a challenge as well. Though the Co-op sees the food service industry as a vital sector in providing outlets for local production, it recognizes a need to go slowly and repair some damage has been done from poor collaboration in the past.

"Restaurants, regardless of the size, tend to be very systematized. They know when they need to order product. They know what it needs to look like when it arrives, and they know pretty

Photo 14: Local cafe with which MVM Co-op worked

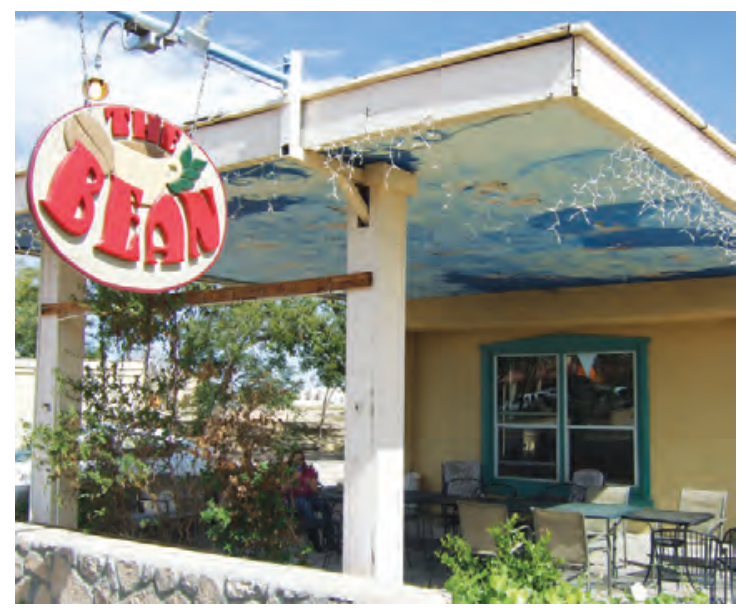

much how much they're going to pay for it. They need all this to develop a menu around it. Local producers often can't guarantee consistency, don't really understand necessarily how much they should charge and don't always produce. So it's hard for a restaurateur to say I want to have this relationship with this person, who might or might not deliver to me, might not figure out that they need to communicate that to me soon enough. That's happened a lot, where they go, "I know we said we were going to bring you 25 pounds of product $X$. We actually only harvested 8 pounds of product $X$. Here you go. Take it at the price we agreed upon... Or without any agreement at all, [the producer] will just show up with a bunch of stuff and say hey, can't you use this? You bought it from me once before." -GM, MVM Co-op

In addition MVM tries to help farmers understand that they will not get farmer's market retail prices selling after-market produce to a restaurant that is buying in bulk and should expect a wholesale price. 
"There's a lot of tension there because then the farmer starts to believe, "you're undervaluing my product. This is how much I'm selling this for. This is what people [at the market] are buying this for." ... So for restaurants, it's a lot easier for them to get on the phone and talk to Sysco [foodservice distribution company] and say, I need this, and I know what the price is going to be. I know when you're going to deliver it. I know what the quality's going to be, and I can be assured that my menu is not going to be compromised." - GM MVM Co-op

Though it has proven to be extremely time consuming, the General Manager has shepherded and cultivated relationships between farmers and restaurants, with

Advert 7: Flyer for a vermiculture workshop at the MVM Farm

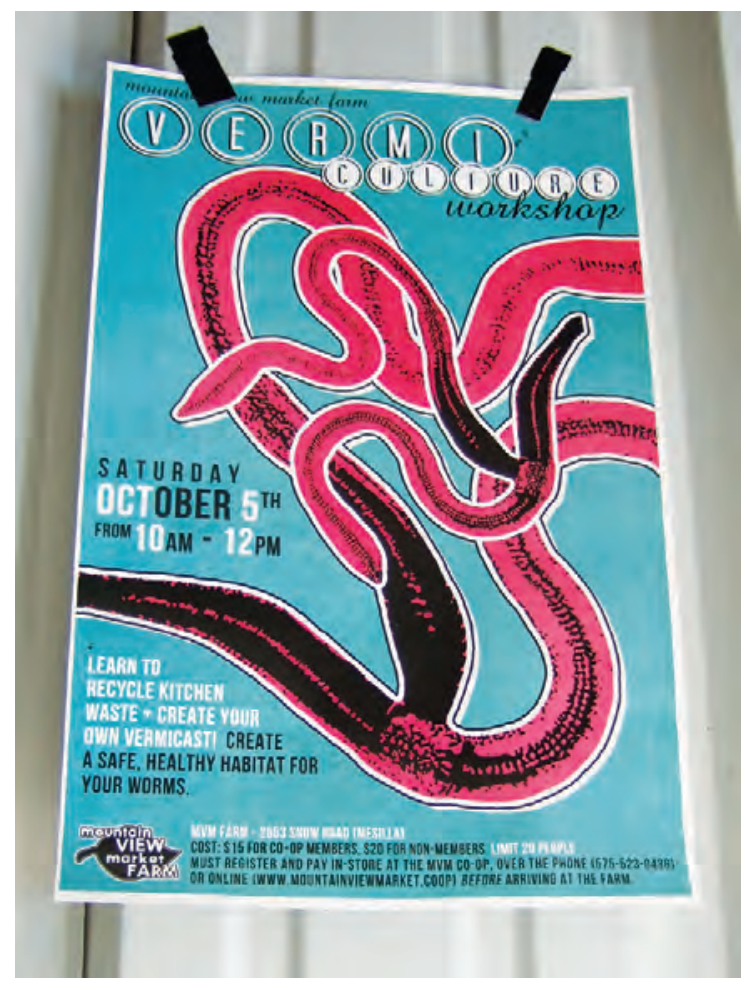

an emphasis on encouraging communication from growers (on production issues and timescales) and on educating restaurateurs about the challenges (environmental and otherwise) that can affect a farm's output.

"We're trying to be in the middle, sort of, and do the negotiation that we need to do so that we understand what the end customer needs, and we understand what the producer wants. We try to get them to both understand what the reality is in the middle and develop a relationship. ... I have a conversation with my restaurants about what's being produced, what price I'm going to deliver it at, and I also have a conversation with them about consistency and say, it's not always going to easily be available. We might have a freeze the night before. I'll work with you. I'll give you a call as soon as I can and let you know what's going on. They appreciate that." -GM, MVM Co-op 
For the Co-op, local food is both an opportunity and a necessity - a defensive strategy against the potential loss of suppliers that also differentiates it in an era of mass market organic. It is a way of encouraging cooperation and partnerships for a more sustainable food system that also uses the food assets of the region.

\section{Photo 15: Non-human residents of MVM Farm}
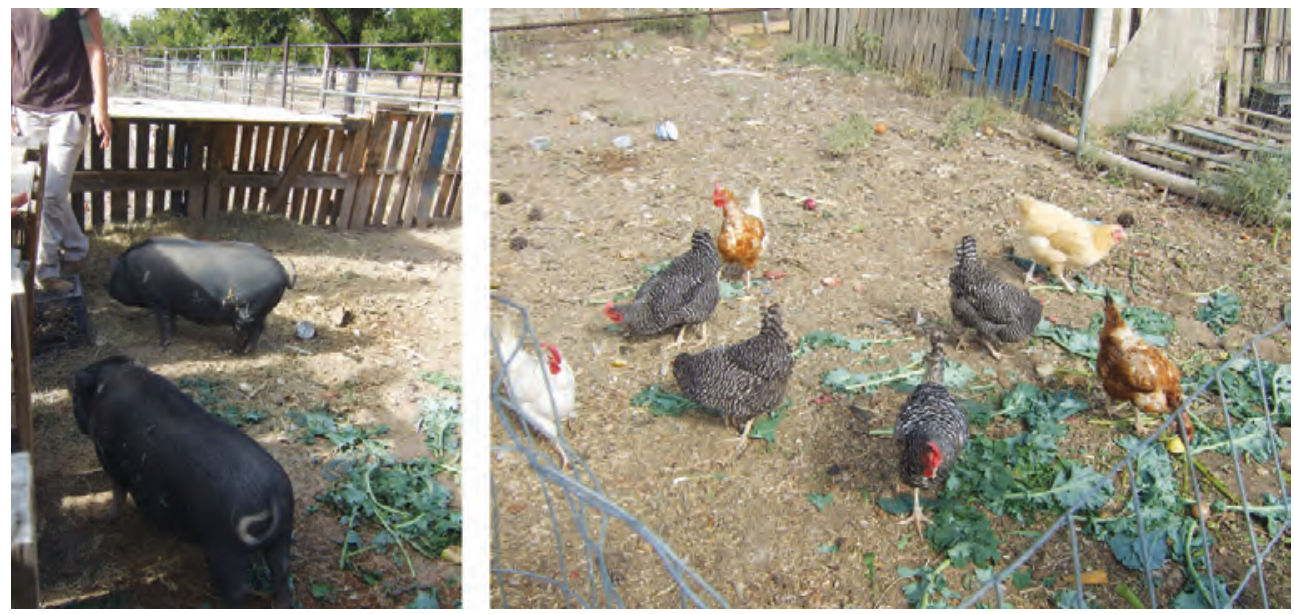

\section{5: MVM Farm and its role in local food}

The MVM Farm is located in a mixed-use residential area a short distance from the Co-op (approximately $4 \mathrm{mi} / 6.5 \mathrm{~km}$ ) via surface roads. There are schools and affluent neighborhoods within 3 blocks of the farm in several directions. The Farm lies on 2.5 acres (1 hectare) and also has a residential property in which the Farm Manager lives. The MVM Farm was not certified organic at the time of fieldwork, but it was growing without chemical fertilizer or pesticides and used many practices of sustainable agriculture (including composting, crop rotation, and drip irrigation). Using drip irrigation was particularly uncommon in this part of New Mexico. Despite the drought conditions and the high levels of evapotranspiration, agricultural operations frequently used flood irrigation, consuming per minute approximately 360 gallons (1362 liters) versus drip irrigation's 40 gallons (340 liters). The Farm also incorporates small-scale animal husbandry (pigs, chickens, and vermiculture) and has an aquaponics system using trout bartered from the Mescalero Apache Tribe in a knowledge exchange. The farm uses no mechanization but has borrowed a ground tiller from another farmer on occasion. 
Photo 16: MVM Farm's drip irrigation system

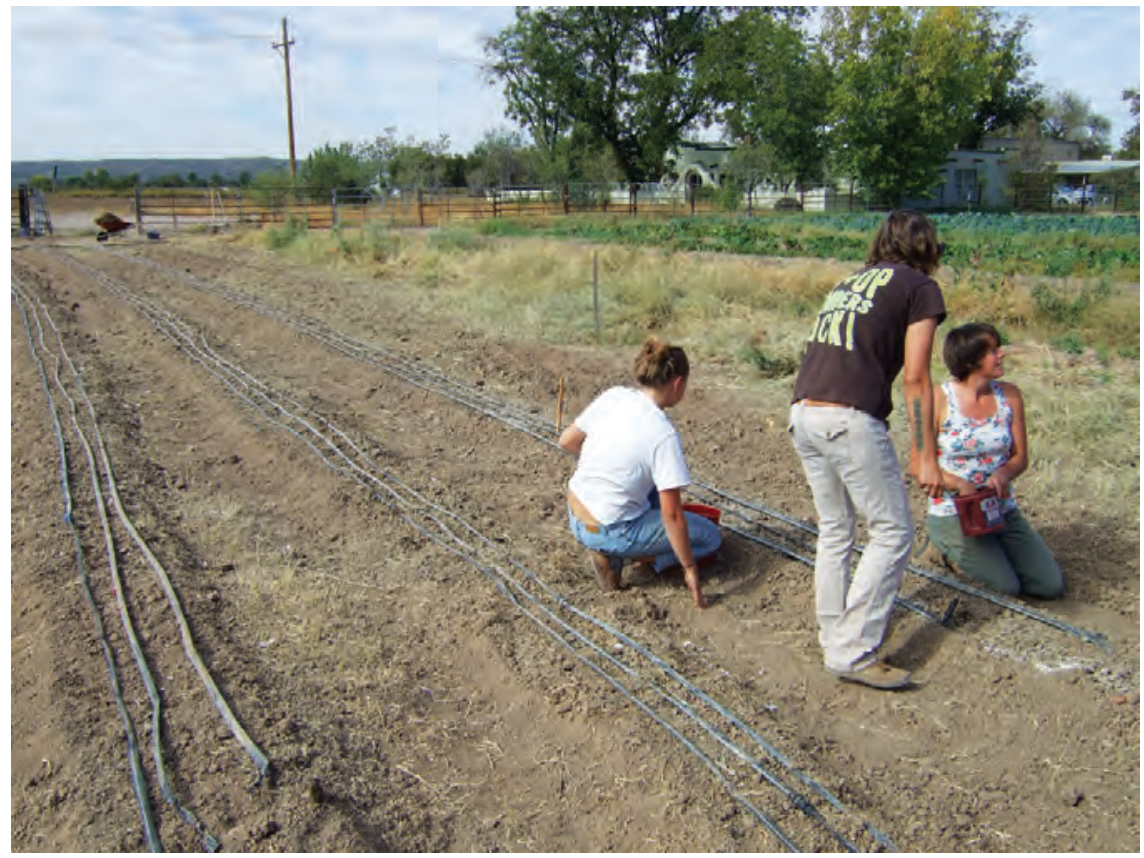

Photo 17: Flood irrigation often used in the region (here, for pecan trees)

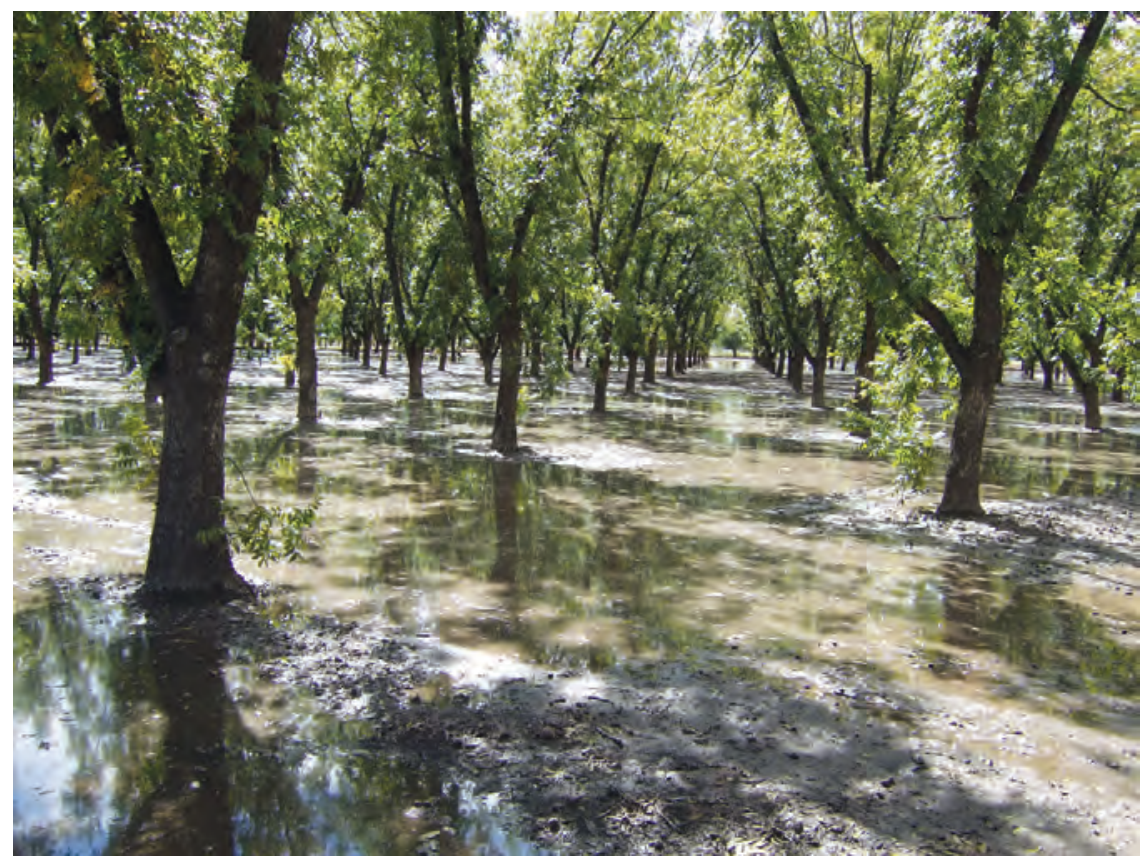




\subsection{1: MVM Farm's development and organization}

The acquisition of MVM Farm in 2011 took approximately one month. For decisionmaking in a co-op, that is a very short timescale. It is understandable, however, when looking at the context of the decision. MVM Co-op began to see the depth of difficulty in increasing production of local produce among the suppliers they were already working with.

"At the Board level, we started having a discussion about food sourcing. ... We said, well, if we have the opportunity to invest in or perhaps acquire one of these local farms, we should do it. ... It didn't take long because it is totally in alignment with our ENDS [mission statement] in providing good food to the community. We did it at a Board retreat, so we were confined for three days. ... So, no, we started talking about this on Friday, and by Sunday morning we had a decision that we were going to try to find a local farm to invest in." - GM, MVM Co-op

Fortuitously, the Co-op already had a relationship with Skarsgard Farms, the Albuquerque-based organic CSA, with which the Co-op had developed a relationship via its online ordering and delivery service. Skarsgard had a satellite growing operation in the nearby Mesilla Valley but wanted to close it down. The owner of the land was a member of MVM Co-op and felt very positively about keeping the land in production and having the Co-op as a tenant. So the decision was taken by MVM Co-op's Board to sign a lease for the land in September, and the MVM Farm was established in October.

All the Farm's employees (all full-time and salaried) were women under 40 years old with varying amounts of agricultural experience. They represent the type of local producer MVM Farm is strategically trying to encourage: people who are dedicated to low-input agriculture but need and want training to be able to do it. Additionally, all the women have had longstanding and significant connections to the Las Cruces community and have a presumed likelihood of staying in the area.

The Farm Manager - who at the time of fieldwork had been farming for about 8 years in the Mesilla Valley with a 1-year stint farming in Louisiana - studied horticulture at New Mexico State University (NMSU), the local land-grant agricultural university. She had devised her own course of study before NMSU even began offering coursework in sustainable agriculture. (Several people commented to me that 
NMSU greatly influences the type of agriculture practiced in this area of the state, and the focus of its curriculum has been high-input, conventional techniques.)

The Farm Assistant had no agricultural experience but had worked in sustainable building construction. She has been learning on the job and has become as specialized in all the tasks in caring for the farm and all that the Farm Manager does. These tasks included animal care, planting, composting, planning, leading workshops, weeding, managing volunteers, and harvesting twice per week.

The Farm Administrator had only been in post for three months at the time of fieldwork and came to the Farm with a background in youth and community development and fund raising in non-profit organizations. Her main immediate tasks were volunteer recruitment, hosting farm tours and events, representing the farm to community groups, handling all administrative work, reporting to the MVM Board, and record keeping at the Farm. A lot of basic administration and record keeping (such as duplicating invoices, logging planting and harvests, documenting volunteer and funding contacts) was heretofore not being done in a systematized way. The Farm Administrator was also charged with cultivating relationships with restaurants, as the General Manager had done, and with managing the Farm's contact with and sales to the MVM Co-op produce department.

\subsection{2: Local food as a community effort}

The Las Cruces community wants the Farm to succeed, according to the MVM Farm Administrator.

"People want to be cooperative, and people want it to succeed, and not just the people who work there, but the community - the academic community, the store community, the Green Chamber community, the other farmers. People are very supportive and well receiving of the farm. ... I think they want to feel good about buying from there because it's organically grown, and it's the right thing to do. And it's a small action to show how they believe about stuff like that. ... because they see that we love it and we're super passionate about it."

It is partly for this reason that the Farm is able to draw upon a lot of volunteer labor, though on an ad hoc basis, from different community groups. The Farm does have a few consistent volunteers and interns that come every week in relation to required community service or work experience. The number of volunteers fluctuates 
significantly, with 2-3 individual volunteers coming several days per week. Groups of fifteen or more have done organized days of service at different times, however.

The Farm staff find themselves doing a great deal of supervision with first-time or infrequent visitors to the farm. This is both a blessing and curse, as more people are exposed to the Farm and its techniques, but there is constant supervision needed for those uneducated in growing and gardening.

"You want to foster people who don't know anything about this, because
that's the point of this - it's to teach them that. At the same time, there's that
risk that they're pulling up your plants, because they don't know how to weed.
Or stepping on the plants, or planting the wrong thing. Or whatever it may be.
... There are people who are really happy to be here and motivated, but they
spend an hour, and you never see them again." - MVM Farm Manager

"People ask me why we are getting into the farming business. I tell them that we're not. We're in the producer business. Our mission is to produce the producers." -GM, MVM Co-op Education in the form of workshops, tours, and trainings is a large part of what the MVM Farm does - all as part of its mission to develop more local growers in the area using organic techniques. Audiences range from primary school to university and community groups - including students at NMSU. The workshops are open to the public and have varying costs, though MVM Co-op members receive a discount.

Though a lot of hobbyist gardeners attend the trainings offered by the Farm, there are also a few full-time farmers that the Farm specifically works with - to learn from and to help improve their operations. They have connected with these farmers through a non-profit community group called La Semilla Food Center, which is also interested in systemic change in agriculture and community food access. Through partnering and sharing knowledge, buying seeds and some equipment together, the Farm is hoping to build a growers' community to advocate and practice organic agriculture.

It should also be noted that the workers of the farm, and specifically the MVM Farm Manager, are the main recipients of the training and professionalization that MVM is trying to offer. The Farm Manager has attended many farm visits and farm 
conferences (both in New Mexico and in neighboring states) on behalf of MVM Farm and feels that she is being trained as much as anyone else.

"I think that when [the GM of MVM Co-op] is talking about us training farmers, I think that he's really talking about me in that sense.... I think the idea behind this is that I am here for a certain amount of time until I feel, or they feel, that I'm ready to go and be out on my own [as a farmer]. That's my goal, to be a small farmer.. Hopefully that's the idea - to foster more people staying here and growing in this Valley. ... And that's what I think they want - to continue that cycle where, after I leave, they'll have somebody else come in, and then that person, hopefully, stays in the Valley and starts producing food and sells to the Co-op and sells at the farmers' markets." - MVM Farm Manager

\subsection{3: MVM Farm and Co-op relations as a negotiated process}

The Farm grows a variety of produce, herbs, and flowers for sale to the MVM Co-op's produce department and Kitchen, CSA box subscribers, and two local farmers' markets each week. The Farm's produce is highlighted in the Co-op's produce department and the Kitchen with signage, and the Co-op does market the fact that it is growing its own food. There are other links between the Farm and Co-op. Farm employees attend staff meetings at the shop and report feeling as if they are part of the organization, though they may not visit the shop frequently. "The Co-op is a fantastic organization, the way they treat their staff... it feels really good to be a part of an organization like that." - MVM Farm Assistant.

There are policies that try to foster closer connection between the Farm and the Co-op: shop employees can get paid up to four hours per month to work on the farm. With few exceptions, however, most staff members do not do this. This is a point of consternation for the Farm Manager, as she feels that it would be important to build an understanding of what it takes to grow food on the Farm.

This may be because the past relationship between the Farm and the Co-op has been complex and frustrating at times, largely due to not having established procedures or effective avenues of communication until well into their collaboration.

"The store advertises 'Come get vegetables from the Farm at the store," but it's more complicated at the Farm regarding advertising this. Sometimes they take our stuff; sometimes they don't, and that's down to a bunch of factors. Consumer demand for uniform vegetables and consistency ... regarding how much we can provide the store with, and there have been no developed process 
or policies and procedures regarding vegetables going from the farm to the store. And we're sort of establishing that [now]... who talks to who or what the expectation is." - MVM Farm Administrator

The sorts of issues that local producers have regarding communication with institutional buyers also occur between the MVM Farm and the Co-op's produce department. These issues concern dependability and predictability of yields and

\section{Advert 8: MVM Farm banner at the MVM Co-op}

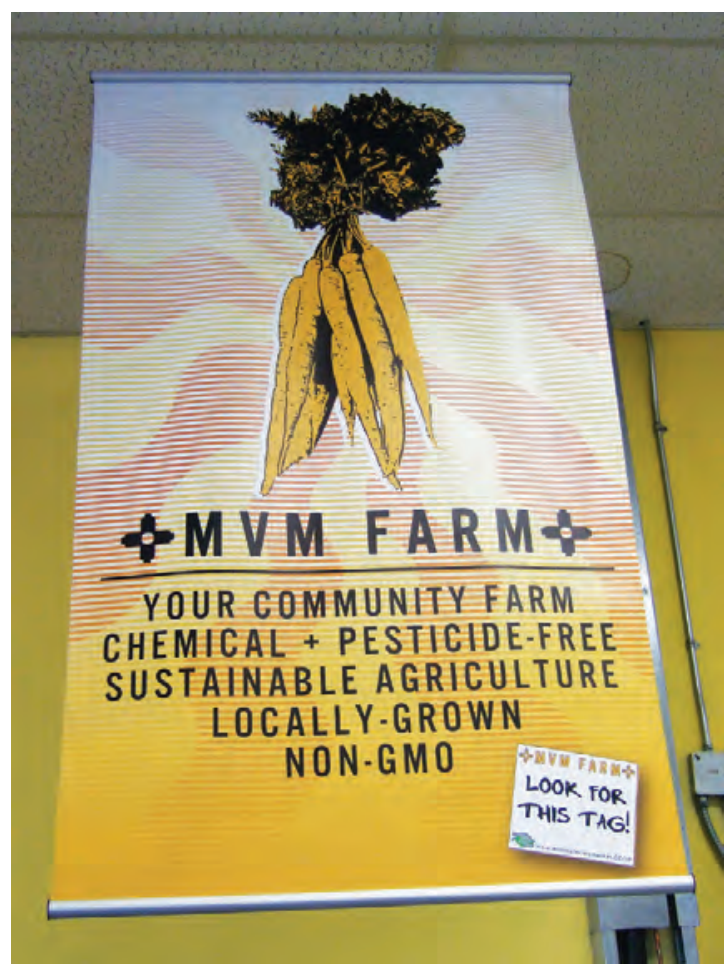

unclear standards and processes. Difficulties had become exacerbated partly due to the rapid expansion of the Co-op at a time they were growing in specific departments and hiring new people. For example, after the Saturday farmers' market, the Farm Manager would bring over leftover, unsold food without advance notice or discussion. New produce clerks would accept it, often not thinking through the tasks that would mean for the produce department. At other times, the Farm has not been able to deliver items promised to the produce department.

It seems to be a constant negotiation, and there is some understanding of the difficulties the Produce Manager and the Farm Manager are each facing, but differences and systems still have to be worked out, according to the Farm Administrator. She has taken over communication between the Farm and the produce department and established regular email communication before harvest days to check in with the shop.

"[The Farm Manager] showed up unannounced at the store one day: "Hey, I have 50 bunches of kale. You'll buy it, right?" But they will have already put their order in at Veritable, or the demand for kale at the store isn't there. And 
we have suddenly created another task for them that is more than they can handle at that moment, because they're really busy, too! Those are my primary impressions of the store and the Farm's relationship, but I do ultimately believe that it's a mutually beneficial relationship. Not necessarily equal, but the store benefits because they can promote themselves as a store with a farm. And the Farm benefits, because we're dependent on the store for certain things." - MVM Farm Administrator

Notably though - whereas the Farm describes the difficulties as misunderstanding the limitations of small-scale organic agriculture - there are indications that the problems are from communication and organizational processes, not from organizational culture, which is harder to change.

"So either we have a surplus and they can't take it, or they want something and we don't have it that time. ... It's a cultural thing," to be able to order a set amount and get it, or to order something that always has the same quality and is packaged the same. - MVM Farm Manager

"Being able to expect local produce from a local farm is a little bit harder, because we're dealing with things like bugs. Or frost got something. Or the caterpillars got something. Or somebody ordered all our whatever [crop]." - MVM Farm Assistant

The Produce Manager did note, however, that a lot has changed regarding procurement of local food in the last few years due to growth in the Co-op. This has required tighter and more efficient procedures to keep pace.

"Well we're also getting more particular. We used to just take anything local. We just wanted to make local growers feel welcome here. Now, it has to be naturally grown, no pesticides. ... But also now we're just getting so busy. In the last two years, we've had about $30 \%$ sales growth. So we're too busy now. We can't be piddling around with like "Oh sure, I'll buy two pounds of your tomatillos, and I'll buy one pound of your string beans." We used to just do that all the time. But now we need to have large amounts, and you need to be dependable. ...Now it's just like way too hectic. We have to have a call ahead. ...I need a week's advance notice, because if I know, okay, you're going to have three dozen green onions for me next week, then, great, I'll cancel my California order. Why buy from California, if I can get local?" - MVM Produce Manager 
Notably, the MVM Kitchen seems to do better at handling deficits and surpluses from the Farm. This is not particularly surprising, as small food service enterprises working with a seasonal mindset can often react nimbly to changes and can use produce of varying sizes and appearance. The Kitchen Manager has made it a point to embrace this ethic of local food (and its attendant uncertainties) that forces her to be creative and more conscious about the food prepared in the Kitchen and Downtown Kitchen.

"Getting food from the Farm happens in a few different ways. We'll call [the Farm staff] and say this is what we need based on the menu needs. Other times, the Farm calls and says "We have too much of something, can you use it?" So it kinda happens in this calculated way, and it also happens in this curveball way, which are both fun. I always try to use whatever it is that they want me to use. I don't like to say no to them for a couple of different reasons: It's a totally closed circle when we produce made-to-order food when we use food from the Farm... but it also is the food that travels the least amount of mileage to get from A to B." - MVM Kitchen Manager

\subsection{4: Local food in a different neighborhood}

The Farm staff, some interns, and the General Manager take turns attending two farmers' markets each week to sell the Farm's produce. One farmer's market was brand new at the time of fieldwork and was located on the outskirts of town near an agricultural supply store. It drew a lot of the rural farming community just outside the limits of the city of Las Cruces. The other farmers' market was in Sunland Park, New Mexico (located just across the border of El Paso, Texas), in the parking lot of an upscale Italian restaurant called Ardovino's Desert Crossing. Though it was 40 miles away from Las Cruces, it was an attractive place to sell, because it had a customer base able to afford the produce from the MVM Farm. The restaurant (Ardovino's) would also buy produce from the Farm and items from the Co-op. The clientele were demographically wealthier and whiter than at the Saturday farmers' market in downtown Las Cruces, a point which was not lost on the MVM Farm Administrator: "MVM does not go to the Saturday market in [downtown Las] Cruces, because there people are just motivated by price." But at the Ardovino's market, people come to do their weekly shopping. "They're dropping, 30, 40, 50 bucks on just vegetables, where, in Las Cruces, that's their weekly grocery budget sometimes. ... At Ardovino's we know we're going to sell out there. We know there are people waiting for us." 
Map 7: Orientation of Sunland Park, NM to Las Cruces (upper left)

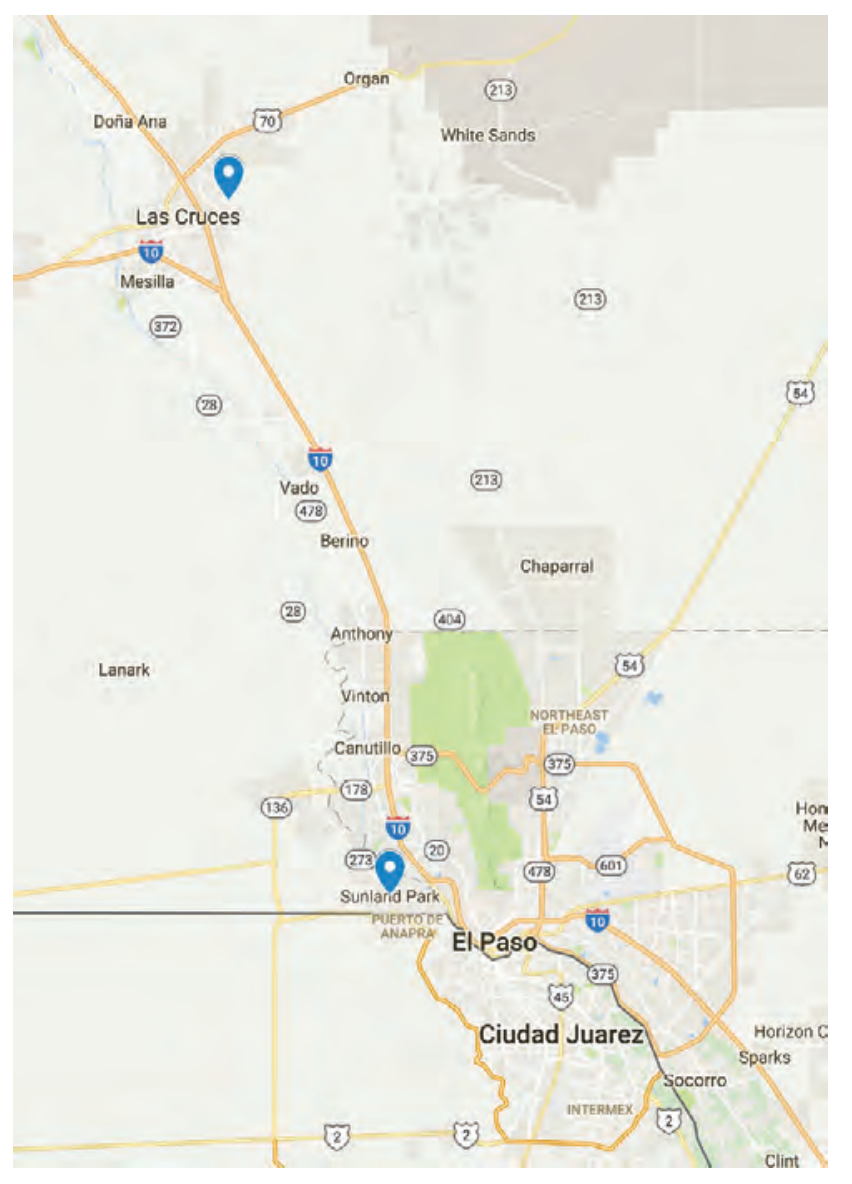

Source: Google Maps, elaborated
This reality of the cost of the food from the Farm still being prohibitive for a lot of people - combined with a different mindset about healthy food - did not sit very comfortably though.

"I feel like: We grow this in Las Cruces; we need to sell it here. That's my first instinct, but I recognize the business model [the GM] subscribes to by going to Sunland Park. Why would we grow it, if we can't sell it, when we can totally sell it here [in Sunland Park]? ... People appreciate it for the novelty feature. They can be like [in an affected voice] "I bought microgreens from Mountain View Market today." ... Those ladies who sat next to us at [an expensive fundraising] dinner - you know they're coming to get their microgreens. And they can tell their friends they eat microgreens." - MVM Farm Administrator

The Farm Assistant described the difference in the customer populations as one lacking understanding about healthy food: "Las Cruces is behind the times in the customers' awareness of what they're eating, what GMOs are and why they're bad. The importance of shopping locally - there's more of that in El Paso." The Farm Administrator disputed this however, countering, "Not in El Paso, just in the culture that comes to Ardovino's. There's a lot of rich white people [there]." 


\section{8 | Chapter Five}

This exchange indicates some of the perpetual critique of the Co-op and of AFNs, namely exclusivity - racially, economically, and ideologically (regarding food). In its desire to make local food provisioning via the MVM Farm a sustainable endeavor, the Co-op must make a case to its customers and the public to help enlarge the market for its products. Recognizing the obstacles in doing that means reckoning with the inherent tensions to be negotiated: getting fair prices that values the work of those in the agricultural community and the economically-stressed reality of the community in which they exist.

\section{6: Post-fieldwork developments}

As mentioned in the Methodology chapter, I learned of important developments at Mountain View Market Co-op that occurred after my field research and the followup contact ended in 2014. Because these changes have implications for addressing the framing of local food in the Discussion and Conclusions chapter, I have included some mention of them here.

With respect to support for local food provisioning, major changes occurred at Mountain View Market Co-op following the official end of this research fieldwork. These were the departure of the General Manager Shahid Mustafa in September 2015 and the closure of the MVM Farm one year earlier. Though the Co-op divested its interest in the Farm in September 2014, the Co-op continued to purchase produce being grown at the Farm for some time afterward. While it was made clear during fieldwork in 2013 that that the Co-op would not continue to support the MVM Farm indefinitely if it could not become self-sustaining, I could find no public statement about the cessation of the Farm. Additionally, the MVM Board - in a seemingly sudden move - chose not to renew the contract of Mr. Mustafa, a champion of strategic engagement on local food at the Co-op. Though there is an item on the MVM Co-op web site in a blog post thanking Mr. Mustafa for his service, ${ }^{87}$ I found no formal mention of his departure in the MVM Board minutes in August, September, or October 2015 when (presumably) the decision would have been enacted.

Through informal discussion, I later learned that Mr. Mustafa had been interested in farming full-time and transitioned out of retail grocery management. Additionally,

\footnotetext{
${ }^{87} \mathrm{Mr}$. Mustafa was succeeded by an Interim General Manager who served in that capacity until becoming the permanent GM in July 2016. http://www.mountainviewmarket.coop/blog/2015/12/4/straight-from-the-boarddecember
} 
the owners of the property on which MVM Farm was located re-appropriated the property for personal reasons. Apparently, Mr. Mustafa continued farming in a different location, as did one of the Farm interns who had done horticultural training at New Mexico State University. In this way, some trained farmers continued to work in agriculture, though Mountain View Market Co-op seemingly no longer saw a role for itself in directly cultivating a community of organic farmers. In addition to these developments, there were other changes in MVM Co-op's programs, including the cessation of its online delivery business and of its participation as a pick-up point for Skarsgard Farms CSA. In total, this indicates a change in the priorities for Mountain View Market Co-op from what was observed during fieldwork.

\section{7: Mountain View Market through the lenses of embeddedness and diverse economies}

In this section, I offer some reflections on how embeddedness and diverse economies appear at Mountain View Market Co-op. Even more than at La Montañita Co-op, the various forms of embeddedness overlap at Mountain View Market. This is most likely due to the practicalities and ideologies of choosing to run a farm. The manifestations of embeddedness highlight what is going on in the Co-op as more than a capitalist economic enterprise.

\subsection{1: Embeddedness}

Renting et al. (2003) articulated an idea of spatial embeddedness that carries meanings of trust, quality, and production processes for either globally traded foodstuffs or for products of short food supply chains. Mountain View Market occupies an interesting place with respect to participating in local provisioning at various distances. The Co-op offers a delivery service to more remote communities in southern New Mexico (e.g., Cloudcroft and Alamogordo) via an online ordering portal. Residents in these communities have few options but to travel significant distances for grocery and food provisions of any kind, so the delivery service of bulk and buying group purchases fulfills a need more basic than that of trust or quality. Through deliveries in these outlying areas, the Co-op also harnesses some degree of interest in natural and organic food and encourages collaborative ideals via the bulk orders arranged through the buying groups.

More complicated, however, is Mountain View Market's participation in farmers' markets and order deliveries outside of Las Cruces: 40 miles away in Sunland Park and 46 miles away to El Paso, each varyingly more prosperous communities than 
Las Cruces. The higher incomes and wider class distinction - which also cut along racial and ethnic demographics - between those areas and Las Cruces is a matter of concern to MVM staff. However, the economic realities of needing customers who value the work of the MVM Farm and will support it financially are unavoidable. In this way, MVM participates in the social embeddedness described by Sonnino (2007b) as a process that must sometimes be defended and that requires a mobilization of social values and constructed identities. As such, an understanding of embeddedness across distance (via values) must be maintained in order for MVM Farm to survive as a commercial enterprise.

Like La Montañita, MVM Co-op uses a trust-based system of labelling produce from local producers that signals ecological embeddedness. This prizes a tendency toward organic practices and environmental stewardship, even without certification, à la Penker (2006). The vast majority of the produce on offer at MVM Co-op is from Veritable Vegetable. Almost all of the rest comes from MVM Farm, which seeks to encourage an environmental ethic within the extant (and future) farming community of the area. This is done through a great deal of civic interaction, from the primary-school level through university students and beyond. MVM Farm puts a great deal of emphasis on technical workshops and on farm visits as ways to engage the public with an ecological awareness of local food, despite being in "Monsanto Country."

An important piece of the ecological argument that MVM Co-op employs is the potential that distributors could cease deliveries to southern New Mexico, such that "What if the trucks stop coming?" becomes a question of vital consideration. While Las Cruces would still continue to have supermarket options available, it would not have the "good food" options that the Co-op espouses and sees as necessary again linking to the spatial embeddedness of Renting et al. (2003).

The civic interaction that furthers MVM Co-op's ecological embeddedness also overlaps with Feenstra's discourse around community food systems and their requirement to focus on public participation, partnerships, and principles to foster the joint creation of sustainable food systems (2002). The social dimensions of this are not only ideological. They also have practical implications for MVM Farm's operation, which depends on a significant amount of voluntary labor from members of the Las Cruces community. The incorporation of voluntary labor in the 
work of MVM Farm is also strategic in MVM Farm's pursuit of non-profit legal status that would allow the MVM Farm access to new funding opportunities. In applying for such legal status, MVM Farm would have to position itself as a community organization serving the public, rather than as a cooperative enterprise. In this way, MVM Farm's mission would become even more explicitly educational and social in nature.

\subsection{2: The diverse labor economy of Mountain View Market}

Though I have explicated overlapping concepts of embeddedness observed at MVM Co-op and Farm, returning to the social reform mission of Polanyi requires a deeper engagement of the economy as a space for ethical action and agency. Further to that, I turn to Gibson-Graham's exhortation to communities to reconsider ideas of work in the building of a community-based economy. The use of different patterns of labor in contributing to the livelihood and success of the MVM Farm shows Mountain View Market is part of a diverse economy described by Gibson-Graham. In addition to having three full-time paid staff members working on the Farm, MVM Co-op employees can be paid to work up to four hours at the Farm each month. While few staff had taken this opportunity, it does speak to the ways in which the MVM Co-op valued the mission of the Farm and tried to be creative in supporting it.

Beyond the MVM employees however, the MVM Farm used a great deal of unwaged labor. Interns and volunteers came from groups of high school and university students in the surrounding area who were engaged in either mandatory or elective service as part of their learning experiences. The high school students mainly came from one of the nearby schools (within walking distance of the Farm) and had a service-learning requirement to fulfill. Some high school students expressed interest in or had some background in agriculture; for others, the choice to fulfill their service learning requirement at the Farm came from a lack of transportation options to go elsewhere. At the university level, however, most interns came from NMSU, the local land-grant agricultural university that is very much steeped in a productionist, conventional growing approach. Several NMSU professors who were interested in low-input and organic agriculture and deeply supported the Farm and its aims routinely brought their students or encouraged students to visit the farm and to volunteer. 
The collective contribution of the Las Cruces community resulted in 100-200 hours of volunteer labor given to the Farm each month by various visitors - mainly in the form of preparing beds for planting, pulling weeds, and harvesting. The Farm has also had contributions of specific skills by various people. NMSU students with media training created a short film about the Farm. Two community members built a solar dehydrator to make dried kale chips for local events and for demonstrations at the Farm. Member-owners of the MVM Co-op are also encouraged to visit and volunteer their time at the Farm. Through the MVM Farm, community members are given an opportunity to learn about and support agricultural systems and practices

Photo 18: Farm Administrator leading a greenhouse tour for school students

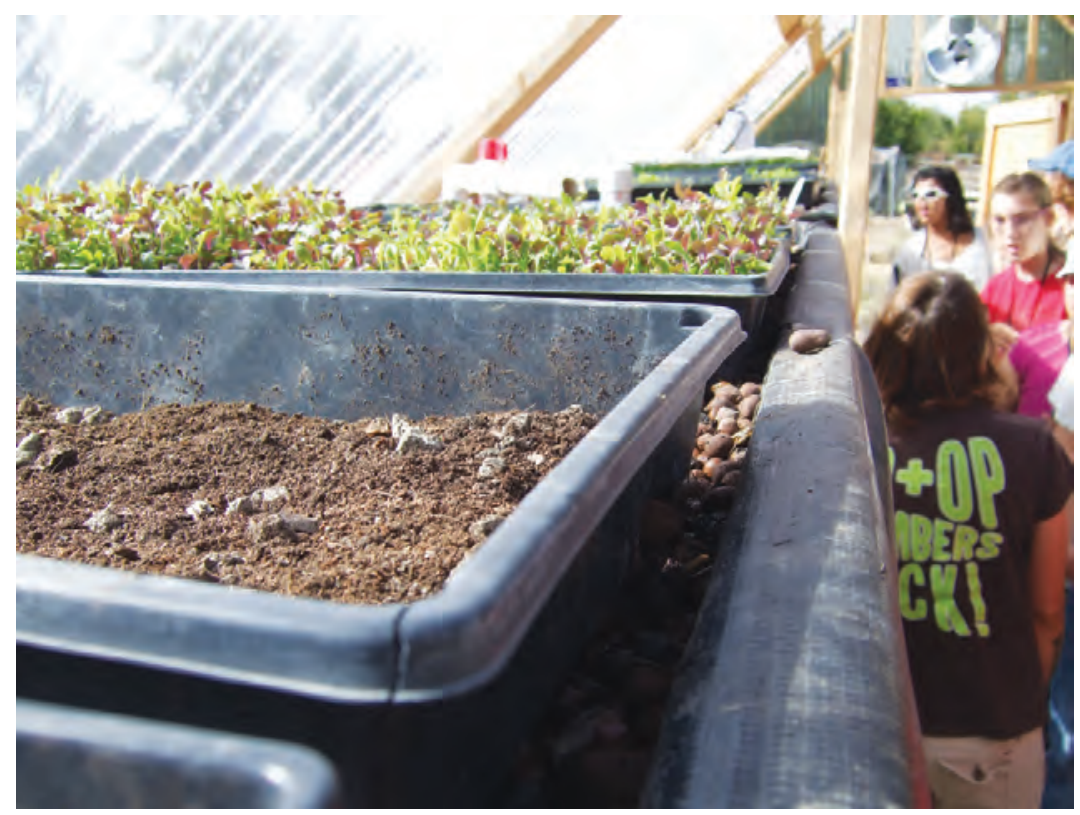

that are outside of conventional systems and to consider the ways in which they can contribute to a community-based agricultural enterprise.

It is not to say that MVM Farm's reliance of voluntary labor is beyond moral or political critique. MVM recognizes that volunteer labor is economically valuable, but it is not compensating that labor economically. Indeed, its dependence on voluntary workers may reflect an inadequate amount of compensation available to recruit enough paid staff, but it is also predicated on taking advantage of other arrangements. For example, those who come to the Farm to work may have some 
sort of structural obligation to do so - as with the high school or university students who have service learning, community work, or required class assignments as part of their academic programs. Otherwise, there are class distinctions involved with using uncompensated labor. People who volunteer at the Farm also have flexibility in their economic or domestic responsibilities to be free to give the Farm that labor, rather than use it for their own survival or comfort. So while MVM's diverse labor economy offers possibilities for connection and learning that volunteers at MVM Farm may appreciate, it is also wise to look more critically at how work is valued in a community-based economy. After all, Gibson-Graham et al. also point out that a diverse labor economy can include undesirable practices - such as slavery - that should be stopped $(2013,38)$.

\subsection{3: Case summary}

Mountain View Market Co-op is unique with respect to local sourcing because of its acquisition of a farm. Pointedly, rather than the Farm just supplying the Co-op, it is seen in a larger vision to create a sustainable agricultural community that will help make healthy (organic) food more accessible, both economically and geographically. With the understanding that "What if the trucks stop coming?" is a real scenario, not just for the Co-op, but also for isolated communities in this part of the state, the Mountain View Market Farm can legitimately be seen as more than just a gimmicky sideline for the Co-op. For the Co-op, the accessibility and security of a quality, local food supply is not a given.

This emphasis on food security has come partly as the result of the ENDS process undertaken by the MVM Board in order to make the establishment of a farm possible. However, there was a true advocate and strong leader in the General Manager at the time of fieldwork. He was the driver in developing local collaboration to "rebuild bridges that were burned" between restaurants and local producers. His particular vision regarding online ordering as a wave of the future encouraged the Co-op to connect more to outlying communities. Though he was not a member of the MVM Farm staff, he instituted and built the aquaponics system. This helped make connections with the Mescalero Apache tribe, who were seeking agricultural training for greater fresh food access and self-sufficiency. The General Manager frequently worked on the Farm and usually staffed the farmers' market booth for at least one shift each week. 
Though the MVM Farm was short-lived, it surely had a longer life because of the leadership and presence that Mr. Mustafa was able to offer. This may be both a testament to Mr. Mustafa's leadership and to the need to have deeply articulated strategies on local food. The accelerated (though not unconsidered) acquisition of the MVM Farm shined a light on how difficult organic food production remains in an area like southern New Mexico and why local has to be at a regional distance. The

Photo 19: MVM's GM constructing the MVM Farm's aquaculture system
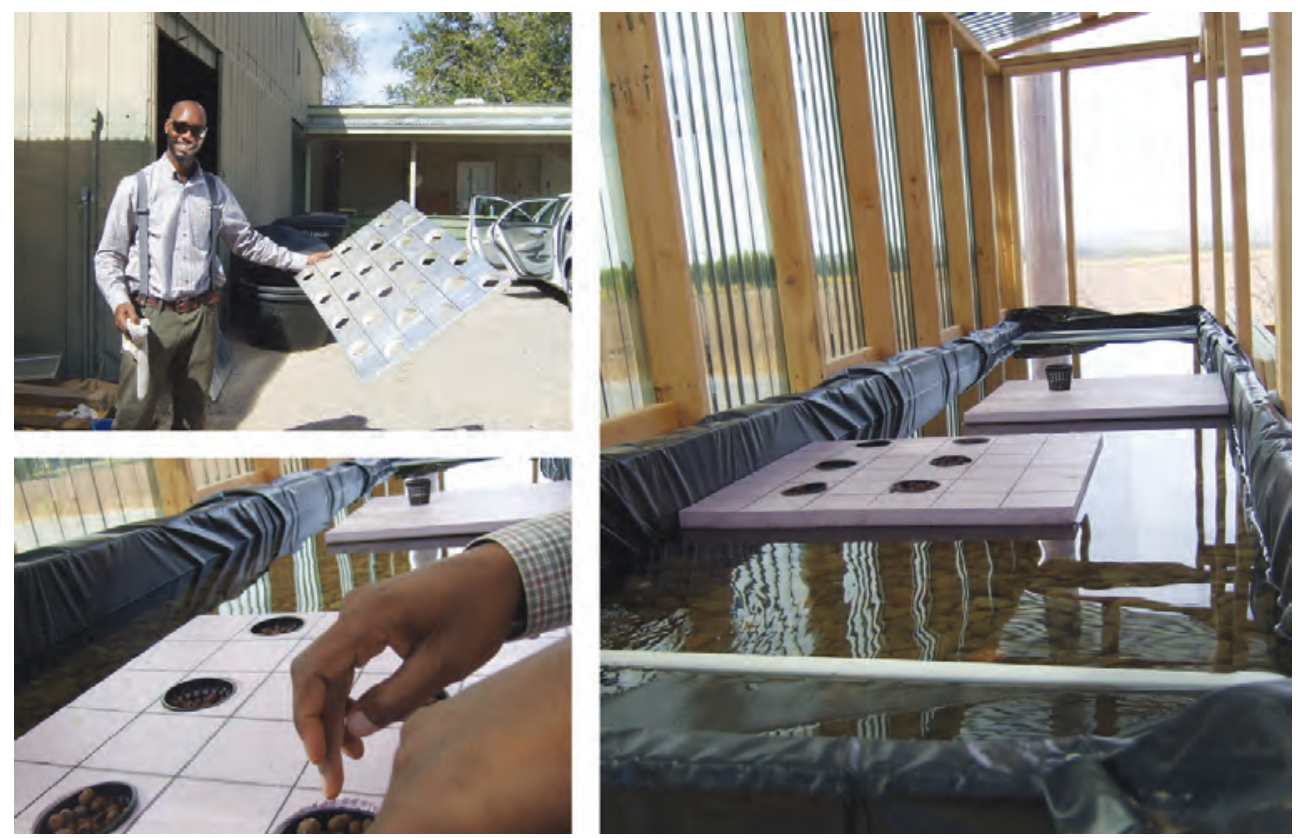

sparseness of the population and the long distances between population centers even more so than in northern New Mexico - make the practicalities of local food more challenging.

The poor fortunes (especially in recent years) of local growers and the difficulty that the Produce Manager has had in establishing fruitful supplier relationships - even with the MVM Farm for a time - accentuated the Co-op's dependence on working with Veritable Vegetable. The consistency, quality, and professionalism of local producers had to be developed prior to, or at least in tandem, with the relationship to the Co-op. Otherwise, it behooved the Farm to sell at local (or not very local) farmers' markets. 
Finally, the reality of the cost of local food and the culture that surrounds it was acknowledged - both as something that enables the Farm to prosper and something that the Co-op is actively working against. That local people on lower incomes are priced out of buying what the Co-op frames as healthy food is a problem - one that the Farm is trying to correct. Still, there is some recognition that quality has its costs that cannot be avoided. 


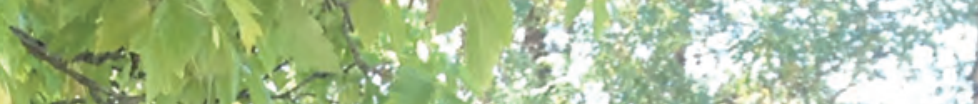

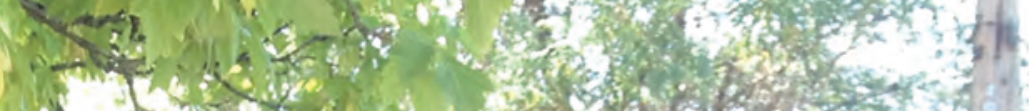

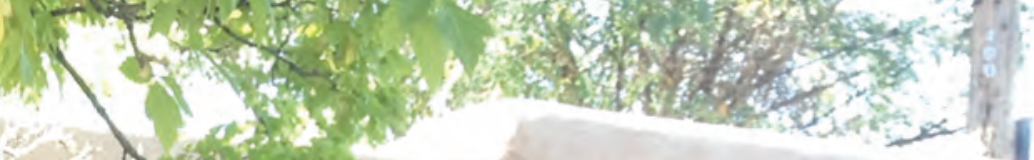
Newe

$\infty$ I
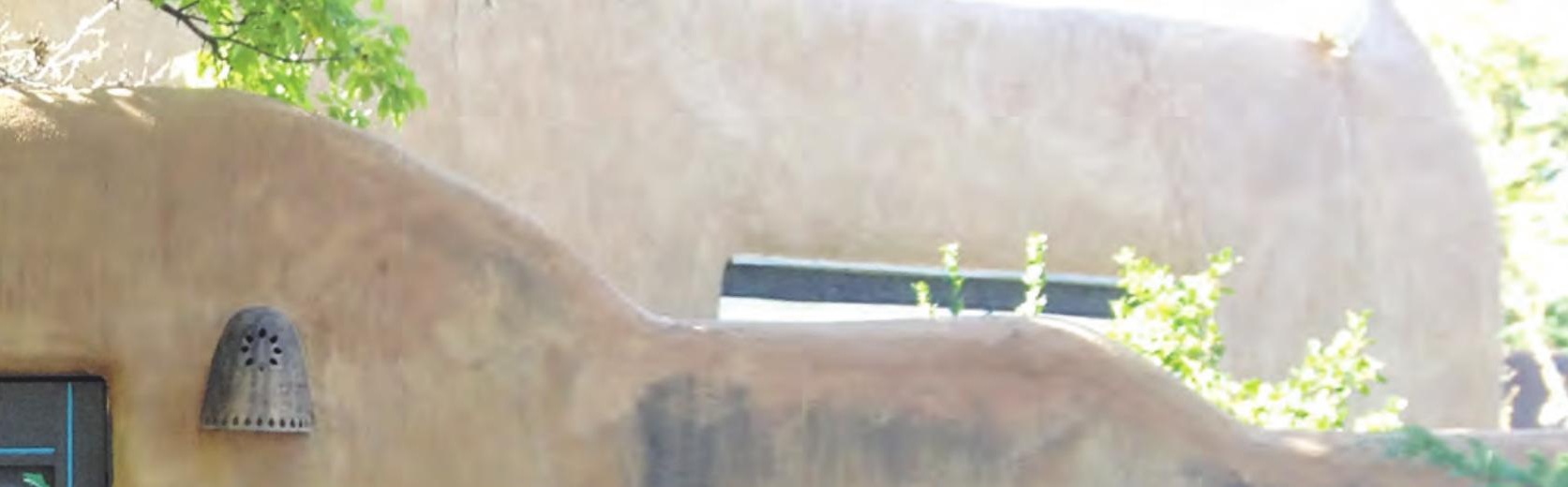

$\frac{1}{6}$

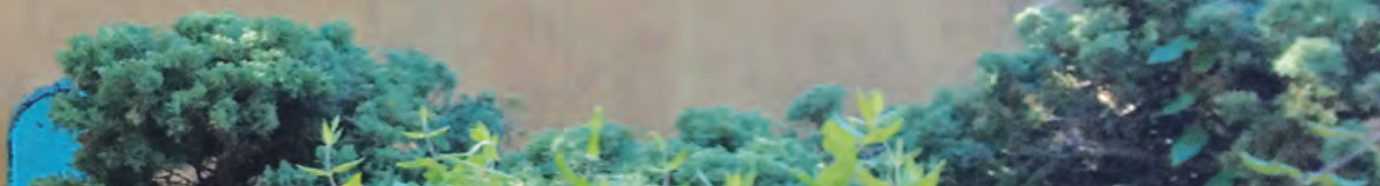

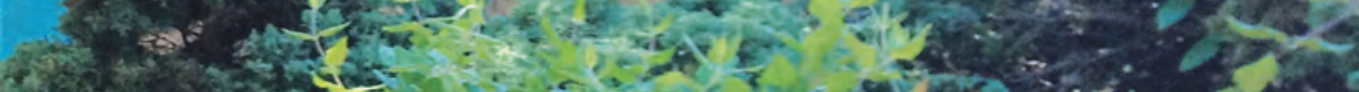

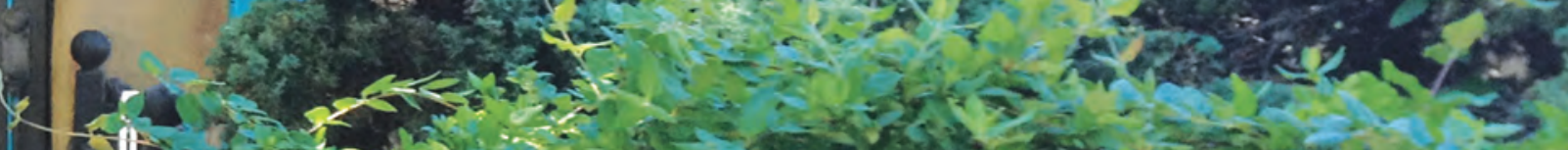

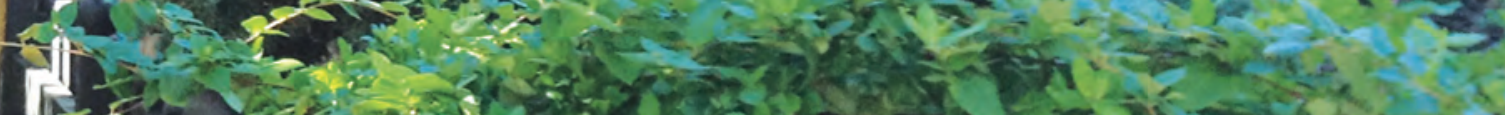
1다. 1 सि की ह

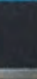

$=51$

a) $30 x+30$
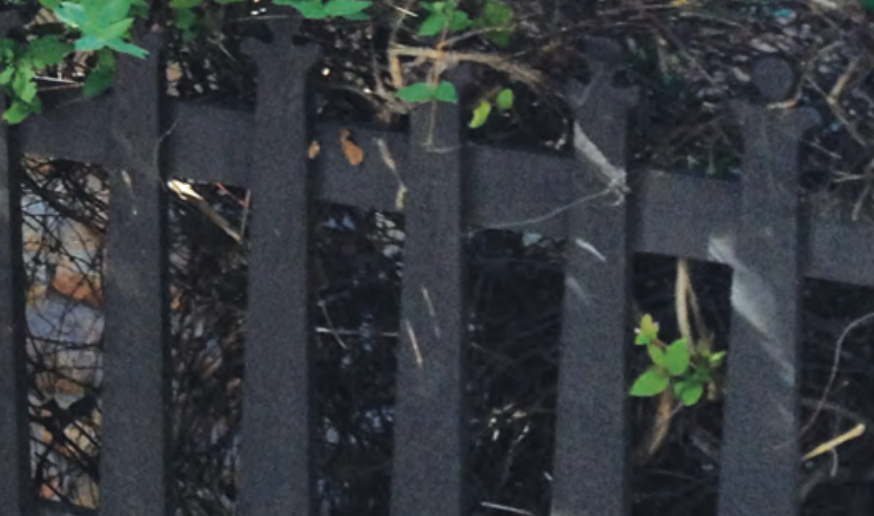

$-1,+20$
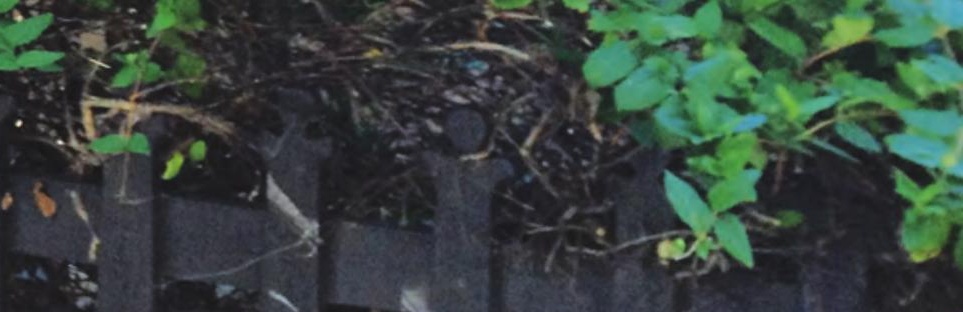

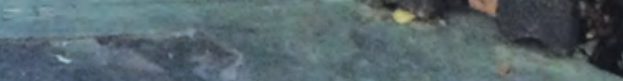
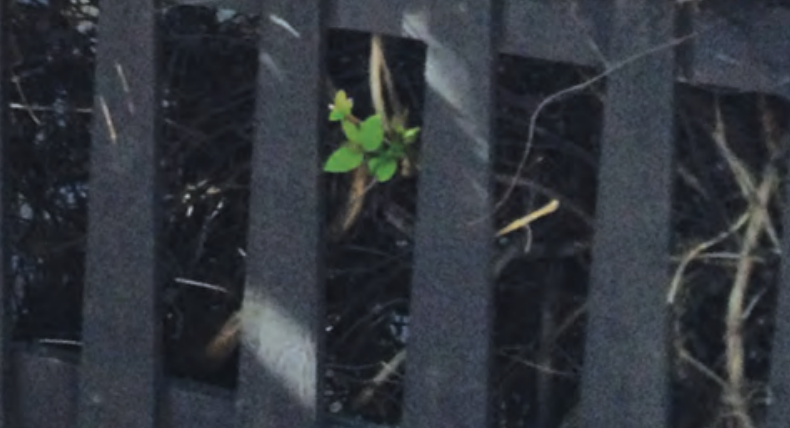
In this chapter, I address the research questions posed in the beginning of this thesis and offer a discussion of how embeddedness and diverse economies can help to explain cooperatives' involvement in local food - both as a manifestation of competitive advantage and as an expression of cooperative identity. I close with some reflections on the research process and suggestions for developing further areas of research.

\section{Chapter 6: Discussion and Conclusions}

The fundamental of co-operation is actually believing in other people. - Peter Couchman, former Chief Executive of the Plunkett Foundation

\section{1: Addressing the Research Questions}

To reiterate, the overall research question of this thesis is the following: Why and how do retail food cooperatives engage with local food provisioning? The specific questions that follow from this are

1) How do cooperatives frame local food?

2) What are the practices that retail food cooperatives use to engage in local food?

3) Do retail food cooperatives have a competitive advantage in local food provisioning? If so, how might that be related to the cooperative identity?

Questions 1 and 2 were previously posed and elaborated on in the case studies for La Montañita Co-op and Mountain View Market Co-op in Chapters 4 and 5. Those questions refer to the perceptions and experiences of the staff of the cooperatives who are delivering the local food provision for each of the cooperatives. In this section, I reiterate some of those answers, bringing the two case studies together. Question 3 is addressed entirely within this chapter.

\subsection{1: Questions addressed in case studies}

1) How do cooperatives frame local food?

a. What do the staff at retail food co-ops talk about when they talk about local food?

b. What do the staff at retail food co-ops say about local food?

This question is essentially made up of two parts, as indicated above, with part A requiring the consideration of the actual topic of the conversation when people 
referred to local food. This is to acknowledge the blurring of topics and conceptual compression that occurs in the discussions around local food and to heed the precaution of Dewulf et al. (2009) to ask what is being framed in the conversation. At times, informants spoke of food or food products, of the local producers or growers, or of the role of the cooperative itself. Part B of the question discusses the actual frame being applied. This awareness was not to diminish the responses of the informants but to recognize the "multiple realities" - after the work of Norman Long (2003) - that are at play in the case studies and to know why there could not be a single frame being applied to local food.

2) What are the practices that retail food cooperatives use to engage in local food?

Following on from this and accepting that how social actors frame issues and problems conditions their responses toward these issues (Fenton and Langley 2011), I answer question 2 along with question 1. Though multiple practices can support a variety or a combination of frames, I give examples of practices paired with frames in answering these questions. The frames touched on concepts of geography, ecology, organizational expertise, community relations, economic opportunities, and education and training needs. This last frame was sometimes articulated as the greatest frustration and difficulty of working on local food provisioning. Additionally, there were frames that were apparent in one case study, but not the other. At La Montañita, this was with respect to access to capital and the need to develop funding mechanisms for local food. At Mountain View market, this was related to concerns about food access and food system vulnerability - and thus the need to cultivate autonomy and food security. Finally, less critically articulated was framing related to the expense and exclusivity that local food carries.

\section{Geography}

Frame: On a basic level, local food has a geographic meaning to both La Montañita and MVM Co-op, as each one uses a 300-mile radial distance from their locations, in Albuquerque and Las Cruces, respectively. While this distance is large, it must be seen in the context that food in the US travels about 1,500 miles or more from its original source of production to the end customer. ${ }^{88}$ Still, the distance was described

\footnotetext{
${ }^{88}$ The Leopold Center at lowa State University has compiled several studies between 1969 and 1997 addressing distances travelled by produce items in a number of states. Those distances ranged between 1,300 and 2,200 miles. http://lib.dr.iastate.edu/cgi/viewcontent.cgi?article=1002\&context=leopold_pubspapers
} 
several times by informants as being regional, rather than local. There is a lack of consensus within local food networks about what distances should constitute locala numerical distance, a political boundary, or a combination of the two. In the latter case, such as a distance could exclude territory that might be within another state or country, even if it fulfills a numerical distance criterion). MVM is one such place that uses the third option. It uses a $\mathbf{3 0 0}$ mile radius - effectively allowing it to call the entire state of New Mexico local - but which does not include Mexico, though its geodesic distance is less than 45 miles away. It may also be that MVM uses the same distance as La Montañita, because they are part of the same distribution networks within the state.

Practice: Both co-ops favor import replacement and support New Mexican products over imports wherever practicable. This requires growers to meet a standard of quality that is acceptable to the Co-op and generally comparable to Californiagrown produce, and at quantities that suit their needs. Additionally, there is a need to have some USDA-certified organic produce to customers for whom that attribute is non-negotiable, regardless of whether (uncertified) local products are available.

\section{Ecology}

Frame: Local food has an ecological meaning in both case studies, as they each prize organic produce, which they also associate with wholesomeness, safety, and quality. Though they mainly sell USDA-certified produce from their supplier Veritable Vegetable, both cooperatives sell "pesticide-free" locally-sourced fruit and vegetables that are verified by trust relations, rather than by spot checks and testing. The amount of faith placed in "farmer-certified" food differs within both cooperatives, however, with some staff members more credulous than others about the agricultural practices professed by some suppliers. This was particularly the case with La Montañita. Conversely, sometimes "farmer-certified" produce was viewed as more faithfully organic than USDA-certified organic food, because of the perceived weakness of the rules around organic.

Practice: As the cooperatives expressed faith in the "cleanliness" of food from local suppliers who were purportedly growing food free of pesticides, fungicides, and herbicides, they were comfortable selling food to their customers labeled as such. The labelling system markets and reflects the value that customers place on organic produce, whether USDA-certified or "farmer certified." 


\section{2 | Chapter Six}

\section{Co-op Expertise}

Frame: Local food is seen as a niche of expertise and a point of differentiation for both cooperatives, but especially in the case of La Montañita. La Montañita claims a particular legitimacy in having long-standing connections to the local supplier community and knowledge about quality products and what customers want. Mountain View Market also offers specific help and training to suppliers wanting to connect with institutional and hospitality industry customers.

Practice: Both cooperatives offer local producers basic information about packing and presenting products and having good communication with buyers. Managers at the La Montañita storefronts are able to procure local products on a case-bycase basis. Additionally, La Montañita offers a limited amount of free marketing and branding services to certain businesses, as well as business development assistance.

\section{Community Relations}

Frame: Local food requires community support and relationships. This goes both ways in each cooperative case study. At MVM, the Farm is trying to build a community of growers with an ethic to develop low-input agriculture. This requires cooperating with existing farm operations, educational institutions, volunteers, etc. La Montañita also has similar values around community and local food and has made special efforts to help customers and producers to connect to one another.

Practice: MVM hosts schools and university groups at the Farm and also goes to schools to talk about the Farm. Through these efforts, they garner volunteer labor to support the day-to-day running of the Farm. MVM Co-op hosts community groups for events at the Co-op. MVM works with low income residents through special programs to help families whose children have dietary restrictions that could be met by buying food from MVM Co-op. La Montañita has an extensive volunteer program to cultivate volunteerism and connection in the local community outside of anything related to its own operations. Producers and vendors attend La Montañita's Earth Day festival and other events (such as in-store product demonstrations) that put them in touch directly with shoppers, as one might see at a farmers' market.

\section{Economic Opportunities}

Frame: Local food can potentially help communities survive and thrive, both through the multiplier effect of recirculating money and through increasing the sheer 
number of local, independent businesses. Mountain View Market sees local food as a potential bulwark against disinvestment from the community by outside business interests who may decide that they will no longer serve the Las Cruces market. La Montañita sees economic development potential in local food, particularly for small producers who can offer customers something unique that is connected to ideas of regional belonging or quality. Additionally, there is the notion that having a product to trade commercially allows one to participate in (and not be victimized) by the globalized food system.

Practice: MVM encourages custom at its shop and other local business through the "We Cooperate!" program, which offers discounts for patronizing other independent businesses. La Montañita offers a range of services for business development to encourage producer professionalization, market access, branding, and distribution support. This is also reflected in the work of the Co-op Distribution Center (CDC).

\section{Training and Education Needs}

Frame: Both cooperatives see customers as needing to be educated about local food expectations regarding pricing and quality and about the challenges that small local producers face. Similarly, both cooperatives see producers, especially farmers, as needing training on the presentation and packaging of their goods, communication and negotiation with customers (particularly institutional ones), market segmentation, and setting prices.

Practice: Both cooperatives invest time and effort in educating producers, through informal one-to-one interactions and pre-planned meetings. Similarly, but to different degrees, both cooperatives have staff talk to customers or have written information in the shops about the local products on offer and what makes them unique or different from imported items.

\section{Access to capital and funding - at La Montañita only}

Frame: Local producers need access to funding and loans, which will make an important and appreciable difference in their capacities to scale up. Cooperative members see the value in this and want to support it.

Practice: Two finance programs - a pre-payment program toward goods that would arrive after invoicing and the La Montañita Fund for microfinance - were created to fill that need. 
Possibilities for autonomy and food security - at Mountain View Market only

Frame: Local food is a path to food security or a defense against changing distribution patterns that leave MVM vulnerable to losing the ability to acquire good, "clean" food.

Practice: Create a farm and recruit and train a local community of farmers to grow what they see as good food (agro-ecological produce).

\section{Difficulties of local food}

It must be said that the frames presented by the cooperatives with respect to local food were not all positive in tone. The framing of local food included some recognition (at both fields sites) of the prices being high - though the final assessment was that the internalized cost of local and organic food are worth paying. Still, there was some tension, such as MVM Farm forgoing sales outlets in Las Cruces to sell their produce in Sunland Park where there are "a lot of rich white people." Thus, the strategy used by La Montañita in its foray into selling conventional produce - in the form of the Clean Fifteen ${ }^{89}$ - could indeed be looked on as a way to address affordability. Nonetheless, the strategy was effectively amplifying class distinctions between customers, in addition to stirring up a lot of concern about this business strategy.

Following on from the frame that local food requires more training and education, staff at both cooperatives said that working with local food and food producers could be a hassle at times. They sometimes felt hampered by sub-standard product quality and by procedural difficulties in working with people. The result was that some co-op staff worked less and less with individual local producers than others might have. There was, at the end of the original fieldwork with La Montañita, an incipient movement to have more coordination on local food purchasing, with the CDC placing large orders for all La Montañita Co-op storefronts. This, it was hoped, would bring in a level of communication, standardization, and economy of scale that would benefit all parties.

\footnotetext{
${ }^{89}$ The Clean Fifteen is the collective name given to a list of conventionally grown fruits and vegetables with the lowest amount of pesticide residue in tests, as determined by the Environmental Working Group (EWG), a Washington, DC-based think tank and advocacy organization. For many people, La Montañita - which had a strong reputation for selling organic produce - was not very transparent about this development when it introduced the Clean Fifteen into its shops in March 2016.
} 


\subsection{2: Competitive advantage, local food provisioning, and the cooperative difference}

Do retail food cooperatives have a competitive advantage in local food provisioning? If so, how might that be related to the cooperative identity?

To answer the final of the three research questions, it is useful to begin with a conception of competitive advantage. Porter (1985) posits that competitive advantage occurs when firms create value that buyers will pay for that exceed the firm's cost of creating said value. The two basic ways of doing this are by offering a cost advantage or a differentiation advantage, whereby the firm offers products at lower costs or offers services, benefits, or qualities to justify a higher cost (ibid, 3, 14). In the case of the La Montañita and Mountain View Market, both cooperatives offer organic food, which is increasingly available through many channels. Their differentiation strategy is to offer local food. In both cases, the co-ops report usually taking a smaller profit margin on locally-sourced products, particularly produce, so that they can pay the suppliers more. As there are also additional costs for local food (mainly in the time and attention needed to work with local producers), the co-ops must also have customers willing to pay those attendant additional costs. As such, it is imperative for firms using a differentiation strategy to signal the value of a product adequately to the customer through education and marketing (ibid, 139).

In this way, cooperatives selling local food that internalizes costs that have been externalized in conventional food production must be able to appeal to household and institutional customers who value that internalization of costs. The role of branding and marketing is essential in this. Having cultivated and showcased extant, long-lived connections to its producer communities, cooperatives like La Montañita have a credibility advantage over conventional grocery shops that may have only recently started selling local food (Katchova and Woods 2013). La Montañita has long had the reputation of being "the farmer's friend" because of its ways of working with local producers - from payment terms, to flexibility in delivery, to consultation about product lines. Their connections with their vendors also allow them to tell the story of the food and the community that supplies it. These longstanding relationships were developed well before its Long Term Strategic Plan around local sourcing existed. It grew out of a concern for its community, which is Principle 7 of the cooperative identity. 
Some important conceptualizations of the benefits of local food concern local power, control and economic development. In this way, Principle 2 of the cooperative identity (see Appendix 2) is useful to understand the effect of democratic decisionmaking on the extant communities. Several scholars and practitioners have documented the significance of "practicing democracy" through local community food initiatives (Hassanein 2003; Levkoe 2006; Welsh and MacRae 1998; Lang 2007). As the industrialized food system flourishes in part through concentration of power, opportunities to voice community needs that run contrary to what the market provides could galvanize people to be critical and take an active role in fomenting change. There can rightly be some skepticism of how much change can be made by participating in the owning and running of a food shop. The Rochdale Pioneers - who helped establish practices and procedures that enshrined the cooperative movement through opening a shop - were, in fact, hoping for no less than a revolution in the economic and political systems of the day. It is clearly spelled out that they saw their vision for a shop as a first step on the way for changing the world: "That as soon as practicable the Society shall proceed to arrange the powers of production, distribution, education and government, or in other words, to establish a self-supporting home colony of united interests, or assist other societies in establishing such colonies" (Rochdale Society of Equitable Pioneers 1844).

In examining the ramifications of consolidated power and control brought by globalization and capital accumulation in the food system, it is clear that the externalities that have resulted go beyond environmental ones, especially considering the effects on rural livelihoods and the fortunes of agricultural communities (Rosset 2006; Holt-Giménez and Patel 2009). As such it would seem that the dearth of democracy is also an externality that cooperatives have the potential to ameliorate by encouraging democratic participation through the management of the cooperative via its internal and external activities. While such involvement might not prove more than a "minor irritant to the dominance of the corporate food system" (Magdoff et al. 2000, 188), participatory systems may offer spaces of resistance and creativity in which people themselves attempt to govern and shape their relationships with food and agriculture (Hassanein 2003, 79).

Going beyond the cooperative principles and from a practical standpoint, the relative scale of most US-based food cooperatives is also a potential advantage in local food provision. Though scale is not an issue moderated by the cooperative 
principles, it offers some competitive advantage over both conventional grocery shops and alternative food initiatives, such as farmers' markets or CSAs. As co-ops have fewer locations and more decentralized decision-making capabilities than national or regional chains, they can be nimble with respect to stocking local products. This allows co-ops to work with many more local suppliers of varying sizes, including small ones that conventional grocery shops cannot work with because of their own regimented systems (Katchova and Woods 2013). Scale is also an advantage in relations to AFNs, as co-ops (either within their networks or via their own capacities) can handle and distribute significant amounts of food. Furthermore, it is through their formation as business enterprises that they can access wholesale markets and channels that absorb much larger amounts of food than, say, an individual CSA or a farmer selling directly to a restaurant. It should further be noted that many cooperatives want to encourage more local food in a system. They are not just preoccupied with having local food sold though their own outlets. As such, they often contribute support, publicity, or space to local growers or farmers markets, as with MVM Co-op hosting a monthly growers' market in their parking lot.

\subsection{3: Addressing the overall research interest}

Why and how do retail food cooperatives engage with local food provisioning?

Though questions of capacity and process always need to be addressed, without community support and a common ethic, no cooperative would be able to work on local food in a substantive way. There must be a consumer demand that will be supported by its members and other customers, and the action must be seen as relevant to its larger social goals. The use of local food provisioning as a pathway to economic stability for both the Co-op and its producer community was clearly visible in La Montañita's Long Term Strategic Plan. La Montañita recognized the need for niche differentiation in an era when natural and organic food is available much more widely than when the Co-op was created (over forty years ago). In many parts of the United States, Wal-Mart and Costco Wholesale - outlets with the average area of 9,700 and 13,425 square meters, respectively - have become the largest purveyors 
of organic food..$^{90}$ Their influence in markets and their command of economies of scale in the food sector creates a David-and-Goliath scenario, in which co-ops must find a new relevance. As such, the starting point to answer the overall research is that local food has to be a potentially profitable locus of differentiation.

In the case of Mountain View Market, their work on local food provisioning is happening in an area with three "Super Wal-Mart" locations. An awareness of the dependence of the MVM Co-op on the good graces, financial fortunes, and will of its distributors to continue delivering to Mountain View was intensely reflected in the comments of the produce manager and General Manager. Though it is unclear whether the same distributors were serving both MVM Co-op and the local WalMart locations, the General Manager at MVM mused about a scenario in which MVM's distributors could choose to just work with the larger players in the area (such as Wal-Mart) or decide it was no longer in their economic interests to continue deliveries to that part of the state. This lends an urgency to establishing systems that could foster some autonomy for the Co-op regarding food provisioning. Thus, for this Co-op and some of the more isolated communities it serves - where major access roads can be cut off by sandstorms, floods, and other climactic conditions "What if the trucks stop coming?" becomes real, not just an idle question in response to queries about the importance of local food. Indeed, this threat is indicative of a critique of the industrialized food system's reliance on just-in-time delivery that is widely used by supermarkets. Dependence on logistics systems that allow shops not to keep much inventory on site saves storage space and allows for more rotation of stock. It also makes shops vulnerable to shortages and non-delivery, which can be particularly detrimental in communities with few food provisioning options.

\section{2: Embeddedness as an economic strategy}

In the theoretical discussion of embeddedness - either as applied to the economic sociology context or to the food studies context - there remains a vagueness in the concept that limits its utility or necessitates a number of qualifications around its use. Embeddedness can include a spatial understanding that may be particular to a territory or a political boundary. Embeddedness can offer an explanation

\footnotetext{
${ }^{90}$ Wal-Mart has a variety of store formats, from large member-only warehouses to progressively smaller outlets being established in urban neighborhood areas. http://corporate.walmart.com/our-story/our-business Costco is a member-only buying club originally accessible to business owners for bulk and wholesale purchasing but now open to individual, personal membership, though the store format remains large-scale. Size details from http:// www.costco.co.jp/p/aboutcostco/worldwide?lang=en
} 
of social structures and relationships that may have to be justified or explained differently over time. Embeddedness may vary across industries and sectors, where spatial scales and predominant production techniques differ. Such conditionality would render meaningless any attempt to create a typology of embeddedness as an end point of this research. Additionally, as so well reflected by Penker (2006), differentiating embeddedness and making sweeping statements - even by examining specific food products on a case-by-case basis - may do little to clarify how one can see embeddedness, because different types of embeddedness are connected and overlapping.

Still, because embeddedness remains a foil to economic neoliberalism and rational choice theory, one can conceive that the continued use of embeddedness (in its variety of forms) renders it useful. Indeed, in looking at the co-op case studies, embeddedness has an empirical use, if not a theoretical one. Embeddedness was enacted through local food provisioning practices, with those practices being justified by how local food was framed. The emphasis on (re)localizing food materialized as business and operational strategies that were used by each of the co-ops. At both La Montañita and Mountain View Market, the flagship initiatives were geographical or spatial in nature - the Food Shed Initiative in the case of La Montañita and the MVM Farm in the case of Mountain View Market Co-op. Although geographical or spatial distinctions by themselves have no explanatory power, this need not be seen as particularly problematic. Those distinctions accompanied different framings for local food that the co-ops used to describe or to justify their engagement with local food.

The evidence of embeddedness via local food also reflects some differentiation that the co-ops value. Whether it is shipping heritage products to former residents now living out-of-state, as Mountain View does, or helping local restaurants to create seasonal menus that highlight traditional New Mexican dishes, the cultural currency of local food is useful. This was especially the case in La Montañita's partnerships with actors in the hospitality industry, for whom their access to local food has also developed a profitable economic niche. Local restaurants can capitalize on "foodie" conceptions of food quality, coupled with the environmental sustainability arguments of local sourcing. This was seen most plainly in La Montañita partner restaurants such as Los Poblanos Historic Inn and Organic Farm, which offered a $90 \%$ locally-sourced menu in the high season. Though Mountain View Market 
had fewer sustained connections with restaurants and the hospitality sector, it saw making (or rebuilding) those connections as part of its mission to grow a local producer community. By helping to educate producers about working with restaurants, Mountain View also had visions of a value chain that would offer sales outlets for local food.

Indeed, one can return to the argument for local food as a potential economic lifeline for both La Montañita and for the local producer/farming community, as organic food has become widely available. In recognizing the financial struggles of the producer/farming community one informant compared New Mexico to "a third-world country" in its need for micro-finance and community-based lending. Undoubtedly, New Mexico has some of the worst economic indicators in the United States, falling routinely in the bottom tenth percentile in poverty and unemployment statistics. Though some informants at both La Montañita and Mountain View Market mentioned that expensive food sold at their shops could deter customers on lower incomes, there was also the acknowledgement that cheap food has hidden costs and that organic and local food bear prices worth paying.

Instead, the prevalent economic discussion at both Mountain View and La Montañita was about the economic development that could be offered through local food sourcing and, indeed, supporting local businesses of all kinds. The idea of the local multiplier effect and other efforts to keep money circulating within the local economy was a thread in many interviews. In this way, addressing local poverty and economic pressure faced by local businesses, farmers, and other members of their supplier networks was a practical goal of (re)localization through embeddedness. Furthermore, in both case studies, ideas of economic prosperity through embeddedness carried signals of a desire for autonomy and local control. It is because of this that the modern ideas of embeddedness from Granovetter's theorization were not enough. The Polanyian conception of a socially embedded economy requires an engagement with social reform. Seeing the economy as a space for ethical action and economic understandings of exchange that move beyond rational choice theory takes one next to the notion of diverse economies.

\section{3: The cooperative as a community economy}

Remembering that diverse economies theory reframes what is happening in communities to show exchange outside of a neoliberal conception of the formal 
economy, I contend that cooperatives are themselves community economies. Gibson-Graham's discussion of diverse economies allows the consideration of a cooperative as a manifestation of a community economy, but in a different setting. The community economy is ontologically similar to a cooperative. In Take Back the Economy: A ethical guide for transforming our communities, Gibson-Graham et al. (2013, xix) define a community economy as a "space of decision making where we recognize and negotiate our interdependence with other humans, other species, and our environment." This process of negotiation would require participation from community members, thus prizing (yet again) ideas of autonomy and democracy that are essential to the seven cooperative principles.

Moreover, the community economy is only established through interdependence and connection as communities work through salient issues of social and economic exchange. This means that a conventional supermarket selling two aisles of organic food does not make a diverse economy. Rather, community-based negotiation, conscious reframing, and creativity are called for. Such is exemplified in the work of co-ops writ large and in both case studies' practices regarding local food. As defined by Gibson-Graham et al., those salient issues concerning social and economic exchange are

- surviving together well and equitably;

- distributing surplus to enrich social and environmental health;

- encountering others in ways that support their well-being, as well as ours;

- consuming sustainably;

- caring for - maintaining, replenishing, and growing - our natural and cultural commons; and

- investing our wealth in future generations so that they can live well. (ibid, xvii-xix)

These matters mirror the engagement of the seven cooperative principles and the ENDS (mission) statements of La Montañita (page 96) and Mountain View Market (page 157), as described in this thesis. Under the conception offered by Gibson-Graham, it is the active questioning and negotiation that cooperatives go through in their democratic decision-making processes that reinforce cooperatives as a community economy. It is important to note, however, that the democratic nature of a co-op can also foster tensions in approaches that may be incompatible 
and irreconcilable. The multiple realities that come to the fore when using an actor-oriented approach further emphasize the diverse economies theory and how different practices can exist within a single organization.

Though cooperatives and other businesses operating with expressly social goals can have non-market oriented practices or transactions that exemplify Gibson-Graham's theory, two particular issues stand out in these case studies. At La Montañita Co-op, evidence of the diverse economy was readily seen in finance. In recognizing the particular needs of its supplier population - especially farmers, whose financial cycles are dependent on the natural world - La Montañita developed innovative ways to help them have access to credit through the Co-op and other sources. In so doing, La Montañita contributed to the stability of its supplier community and, in turn, its own ability to sell local food. Mountain View Market, through its Farm operation, engaged in a diverse labor economy that was part of its outreach strategy. By recruiting volunteer labor to learn sustainable farming practices and help meet its own production goals, MVM was able to engage a community of supporters to encourage ideas of food security through local food. As was mentioned in the case study however, there remains a significant issue of undervaluing the uncompensated labor on which the Farm relied.

\section{4: Implications of post-fieldwork developments}

The use of reframing the economy to highlight diverse economies comes into stark relief when considering the changes and upheaval that have affected the field sites of this study. Diverse economies theory allows for the coexistence of non-capitalist and alternative practices, along with capitalist ones. One can thus use the theory in both directions to explicate what is happening at a cooperative by seeing what behaviors exist that may also reaffirm capitalist approaches and where the tensions may lie. This was useful in understanding the points of friction that showed up in how the cooperatives operated and further signaled the multiple realities existing in the case studies.

Though the topic of this research has been local food, fieldwork revealed that informants were using language around local food as a proxy for a variety of issues. Foodstuffs and their attributes (including heritage, provenance, and systems of production) came up in discussion; but so did local producers and their needs, knowledge, and expertise. The approaches and work of each of the cooperatives 
also were part of the conceptualization, when informants spoke about local food. Furthermore, in remembering the proviso from Dewulf et al. (2009) to consider what is being framed, it is wise also to employ Hinrichs's caveat (2003) about conceptual compression, wherein attributes are perfunctorily overlaid on a subject - such as a presumption of organic products also meeting ethical labor standards.

At Mountain View Market, the framing of the Co-op as an active player in creating a local agro-ecological farming community ceased when the Co-op divested from the farm on Snow Road. Though MVM Co-op separated its financial interest from the MVM Farm in 2014, it continued to purchase produce grown there for some time afterward. Because the MVM Farm's longer term goals were to become a non-profit 501(c)3 organization with an explicitly educational mission, the Co-op's withdrawal of financial support from the Farm was likely inevitable at some point. The lack of clarity and scant documentation publicly available about the process under which MVM Farm ceased operations renders one reliant on conjecture though. The same can be said for ending the employment of the former GM, who championed autonomy and future food security of the Co-op and its environs. In this way, the articulation of rationales and practices that justify an engagement with local food seemed to depend on a key individual, as well as the logistical capacity to carry through the vision of local food.

MVM's contribution to building an agro-ecological farming community was through its educational work on the farm and participation in farmers' markets. Though the benefits and lasting effects are hard to measure, the legacy of that work may continue through the farmers, volunteers, students, and community members who learned about or were trained in agro-ecological techniques at the Farm. Thus, by actively educating community members (and not just using their voluntary labor), MVM Co-op was able to demonstrate its cooperative principles in concern for its community, as MVM frames local food as a matter of self-sufficiency and independence.

I did not interview household-level customers in this research, but given the comments and backlash toward La Montañita's introduction of the Clean Fifteen, customers clearly also had conceptions of local food and the food carried by La Montañita generally. These conceptions include additional meanings that help explain the pushback that the Clean Fifteen received. It is notable, for instance, that 
local produce was still acceptable to the Take Back the Co-op movement. Petition proposal VI was to "Remove the "Clean Fifteen" and all conventional produce (except local, pesticide-free produce) from Co-op stores and the CDC, effective immediately." This indicates consumer presumptions of trust and the worthiness of support for the local farming community, even though some produce is not certified organic. Minutes from the Board meetings in the spring of 2016 held shortly after the introduction of the Clean Fifteen was announced include comments that decry the decision - not just as a concession to cheaper food, but also as a lack of democracy and a bow to expansionist and capitalist modes of doing business. ${ }^{91}$

The introduction of conventionally-grown produce reflects acceptance of a more industrialized form of agriculture. In pursuing this path - at least to those La Montañita customers and members who rejected it - the Co-op was abandoning its environmental ethic, despite the management's assertion that even more organic produce would also be offered for sale. The Take Back the Co-op movement also explicitly rejected what they saw as the unwise pursuit of growth, represented by La Montañita's expansion to another location in Albuquerque's Westside area. The new location had failed to turn a profit and was seen by Take Back the Co-op as unnecessarily drawing down the revenue that La Montañita had.

Though the framing of local food has not lost its environmental meaning at La Montañita since fieldwork, perhaps the environmental framing of local food is diminished by the Co-op's emphasis on the Clean Fifteen. The rationale of introducing the Clean Fifteen was that it could bring more economic stability to La Montañita and allow greater access to customers who wanted to shop at the Co-op but could not afford organic produce. It was unclear whether the Clean Fifteen would also be sourced locally. If so, it is possible that the economic framing of local food and the multiplier effect of supporting local growers remained intact. It is also possible that the loudest voices against the Clean Fifteen were the ones heard, but a contingent of suppliers and customers may actually have been appreciative of the change. Though the Clean Fifteen program was ended at La Montañita, approached in a mindset of learning as a community economy, the non-acceptance of the Clean Fifteen was a useful lesson to the Co-op's management.

\footnotetext{
${ }^{91}$ Though the Clean Fifteen was unveiled in the spring, issues concerning employee unhappiness, the amount of waste being created by unsold food, and other problems are reflected from February meeting minutes onward. http://lamontanita.coop/directors/documents/
} 
It is useful to recall that - though there is an understanding of cooperatives as socially embedded enterprises - there remains a deep awareness amongst co-op staff members of needing to be economically successful in order to carry out the work that co-ops want to do. "No margin, no mission!" was a slogan I heard often repeated to emphasize that all the community work that co-ops do must be paid for through the success of its business operation. Moreover, in many ways, cooperatives use a number of the same strategies that AFNs employ in direct agricultural markets (such as CSAs and farmers markets). For example, hallmarks of AFNs include using strategies to reintroduce trust in interactions (Whatmore et al. 2003) and bringing consumers and producers closer together (Renting et al. 2012).

In the case studies, this could be seen in many instances. Mountain View Market focused on bringing people (volunteers, school groups, Co-op shoppers, etc.) to the MVM Farm, connecting with them at farmers' markets, and making presentations and appearances at civic events. La Montañita made use of producer demonstrations in their shops or at booths at the Earth Day festival. They developed publicity and marketing materials highlighting local producers and their "stories" to customers. They advocated for rights and more education for local producers regarding Federal legislation that would affect their operations. Furthermore, La Montañita used its experience as both a buyer and a seller of food to position itself as a bridge between producers and consumers to aid the collaborative development of food products and product ranges. By facilitating interactions between suppliers and consumers, La Montañita was also working in the manner of "co-production" or "co-sumption" described by Renting et al. (2012, 300-301).

\section{5: Considerations for the alternative food world}

Having discussed the use of embeddedness and diverse economies as a tool to examine cooperatives, I further suggest that cooperatives should be addressed by alternative food scholars. Retail food cooperatives, despite having significant overlap with and being worthy of more inclusion in that body of literature, are not well represented. It may be that retail food cooperatives - having to operate well in capitalist settings in order to be successful - occupy a liminal space that does not position them easily in AFN literature, which for years has focused on conceptions of anti-capitalism in various forms (Campbell 2016). Indeed, as retail food co-ops can act as a (not-so-removed) middleman in the provisioning of local food, they may be further overlooked in favor of farmers' markets and CSAs that offer more 
direct contact between producers and consumers. Yet, for this reason, diverse economies theory is even more applicable in trying to understand cooperatives. It crucially allows for a variety of practices from capitalist to non-capitalist, with a clear emphasis on bringing to the fore practices that are below the capitalism waterline of Gibson-Graham's iceberg. Those practices are extant in communities but typically go unrecognized, including the microcosm of the cooperative world $s$ described in this thesis. As this research has shown, cooperatives are very much a part of this diverse economies thinking.

Cooperatives are also useful to consider when addressing issues of economic sustainability and scaling up AFNs. As cooperatives use a business model to carry out their work, they often have organizational advantages that AFNs might not have: financial streams and supplies that are not dependent on donations; business plans to manage growth and contingencies; professional staff rather than volunteers who might be overtaxed; and legal and advocacy networks (Caraher et al. 2015). It is possible that cooperatives might have some helpful insights to offer AFNs that are working on the same issues of the broken food system. But, given the need to work within capitalist environments, how much can co-ops interested in alternative food and sustainability challenge capitalism?

Indeed, while one cooperative might express more radical values, another one may focus wholly on serving the needs of its membership without any particular professed political stance. Some cooperatives are expressly interested in reducing poverty in agricultural communities via fair trade, etc.; still another might exist simply because people may find it the most advantageous way of organizing their work. As businesses, cooperative societies might be inherently pragmatic (or equally as idealistic as they are pragmatic) (Lawless 2003). Cooperative economics represents a different sort of (collective) ownership model and may be seen as a third way - neither fundamental socialism nor unfettered capitalism, but one based on mutualism and the need to address some instance of market failure (Hueth and Reynolds 2011).

Taken to the $\mathrm{n}^{\text {th }}$ degree, however, this stance refuses to ascribe any political content to cooperative enterprise. In such a case, it becomes purely a business model working within a capitalist market. Groves's paper on cooperative philosophies demonstrates this contentious and long-running debate about the purpose of 
cooperatives. Witness an exchange following the remarks of an executive of Lando-Lakes, a large producer-owned dairy cooperative in the US:

"My premise of cooperatives is that they are economic instruments existing and operating to increase the profitability of their owners - nothing more, nothing less. ... Neither do they have any particular role to play in promoting or defending social values, movements or structures, however desirable they may be" - CT Fredrickson, quoted in Groves (1985).

Groves quotes Rod Nitsestuen, then Executive Secretary of the Wisconsin Federation of Cooperatives, as responding to Fredrickson in a cooperative newsletter by stating that there need not be dissonance between good business practice and cooperatives:

"The answer really lies in our vision of cooperatives. If cooperatives are viewed only as gas stations, fertilizer supply outlets and milk handlers, then you can be sure that today's farmers aren't going to turn to cooperatives as a solution to their problems. In the alternative, if cooperatives are seen as a means by which farmers can gain greater control of market channels and thus gain greater economies of scale, greater market power and a better chance to be profitable, then co-ops will be viewed as a part of the solution. This isn't just philosophy or rhetoric. How co-ops answer these questions will largely determine their future, their role, and perhaps their existence."

In addition, Fredrickson's statement disregards the way in which cooperatives explicitly suppose a different model of ownership and profit distribution than the one that is fundamental to neoliberal capitalism. While the cooperative movement expressed itself in the creation of a shop for its members who were unable to get affordable, quality food, it was also an acknowledgement of systemic inequity and the time's harsh conditions for poor people. Most of the original Pioneers were steeped in years of working-class activism and in the ideals of the Welsh entrepreneur and social reformer Robert Owen (Fairbairn 2001). At the end of the 1800s, between a quarter and a third of the UK population were living in poverty (Birchall 1997, 3). Moreover, they were also disenfranchised, as Parliament only allowed voting rights for property-owning males with other pre-conditions, so the lack of political franchise would have resonated strongly among cooperators. 
Of course, with respect to the dearth of co-op representation in the academic literature on AFNs, it is useful to recall the work of Chantal Mouffe. Mouffe describes oppositional identity as a core of identity politics: Identity is relational to something or someone else, and a difference must be affirmed in order to construct that identity. In short: "every order is political and based on some form of exclusion" $(2005,15-18)$. So an anti-capitalist alternative food movement may not know what to do with a cooperative food business. Similarly, within a co-op, there will naturally be further tensions manifest, as elements exist that partially oppose the capitalist system in which it must thrive. This might especially true as cooperatives become larger and more influential - such as is seen in the European context and especially in circles where the there is a tendency to think that [perhaps only] "small is beautiful."

\section{6: What about democracy?}

The rhetoric of "food citizenship" and "food democracy" as used by alternative food is a complex question. Lang (1998) proposed the idea of food democracy to demonstrate food as a place to enact the democratic process in recognition of the increasing corporate control in food provisioning. Some alternative food movements specifically incorporate slogans of citizenship and voting through participation in market consumption. "Vote with your fork! Vote with your [insert currency here]! This presents a melding of anti-corporate, yet consumerist, frameworks, highlighting a tension discussed in the literature (Johnston et al. 2009; Welsh and MacRae 1998). Predicating inclusion (or the possibility of it) on one's marketplace expenditure may be at odds with rights-based ideologies that undergird food democracy and citizenship. Other scholars, however, posit that consumption and citizenship may indeed be compatible and demonstrate a new political reality (Barnett et al. 2005; Lockie 2008; Soper 2007), especially as older forms of civic engagement (voting, church-going, and membership in community organizations) have decreased. Either way, the ideas of ethical consumer behavior remain conspicuous and foundational to many alternative food movements.

Cooperatives in food retailing have specific mechanisms of democratic decision making that address a range of issues on a variety of levels. The governance approaches used by co-ops can be radically diverse. They may be organized using models exemplified by the case studies of this research, wherein the Board stays out of management and operational decisions. There may be referendum-style 
models, wherein all member-owners vote on daily operational issues, or there may be a combination of forms. Co-ops can have extensive debates about what they sell and how they work - whether that is the sourcing of particular products to conform to various standards or the use of payment mechanisms (such as credit cards), which support financial systems that some judge to be exploitative or unethical (McLaughlin 2007).

Procurement and sales decisions, such as whether to sell alcohol and cigarettes or to sell products from multi-national corporations, are typically based on a cooperative's own emphasis on and interpretation of the seven principles - even if specific stocking decisions are not devolved to all members..$^{92}$ In the best case scenario, the ethics and behaviors of a cooperative - and the ways in which a particular cooperative chooses to enact the cooperative principles - do take into account the desires of the membership. Democracy makes it such that a cooperative can decide how it would like to align itself and carry out the cooperative principles, but the bylaws and approach of the co-op towards management decisions affects this. Members expect to have some say on important issues. With respect to the introduction of the Clean Fifteen at La Montañita, this expectation was not met, despite the ecological/environmental framing used by the Co-op itself (and also apparently deeply held by many members).

While cooperatives in food might be politically radical about food regime change, other cooperatives (e.g., including many in the agricultural sector) can be rather conservative and profit well from the corporate food regime as it stands. As such, this dichotomy in defining "alternative" versus "conventional" may not be so easily assumed with retail food cooperatives. The broader cooperative movement seems to embody both conceptions, and the longevity of any individual co-op may well depend on its ability to hold in tension (and in balance) its business orientation and its social goals.

\section{7: Reflections and further research}

Over the course of this academic endeavor, I found myself in the fortunate position of having my presumptions upended several times - as would be hoped for in an

\footnotetext{
${ }^{92}$ For example, see the extensive discussion and political process of a proposed boycott of 5 Israeli food products at the Brooklyn, New York-based Park Slope Food Co-op. http://www.nytimes.com/2012/03/28/nyregion/parkslope-food-co-op-to-decide-on-boycott-vote.html?_r=0
} 
abductive reasoning processes of interpretive research. Here, I first reflect on the approaches and methodology from this research process. Interwoven in these reflections are some suggestions for further research on the topics touched on by this thesis.

\section{On theoretical considerations}

The idea of researching food cooperatives for this thesis sprang from presentations regarding the 2006-8 world food crisis at a conference some years ago. Speakers opined about the influence of speculation, fossil fuel dependence, industrial capitalism and its attendant price spikes in different world commodity markets. One speaker discussed the "double movement" concept described by Karl Polanyi in The Great Transformation. The double movement describes how the workings of industrial capitalism triggers repeated cycles of market liberalization and expansion, followed by destructive collapses, then followed by regulatory reforms to stabilize the economy. This cycle's effect on the food crisis has been described in the food regime work of McMichael (2009a) and others (Ghosh 2010; Rosset 2008).

Given this effect of capital, I wondered how and whether alternative food movements could actively engage in capital, and which ones were doing so. This led to investigating cooperatives and the cooperative movement because of the democratic structure of their governing model and possibilities of social accountability beyond the bottom line. In delving further into discussions of The Great Transformation, however, I came to understand that the embeddedness concept that I had encountered in AFN literature also originated there (by way of Granovetter), though the meaning had diverged markedly from Polanyi's (limited though influential) mention of it. This understanding led to me incorporate a historical view of Polanyi's work and to see the connections to cooperatives in The Great Transformation (mainly through Polanyi's stated admiration of Robert Owen, one of the founders of the cooperative movement). This historical perspective reflects creative thinking across domains, a component of the process of understanding diverse economies, as suggested by Gibson-Graham (2008). Yet, the continued use of the embeddedness concept divorced from its origins and with non-specific and ambiguous definitions invites a vagueness that will reproduce ambiguity when discussing it in alternative food literature. 


\section{On case study selection}

During this research process, I was struck by the diversity and scale of the cooperative movement and different sectors' conceptions of the social and environmental issues that are also touched on by AFNs. This extended also to what was happening within sectors, highlighting further the cooperative as an expression of local or regional solutions and creativity. For instance, a UK field site shelved early in the research process adamantly expressed disinterest in working with inexperienced farmers to supply their cooperative. This is clearly a very different approach from the one taken by La Montañita regarding the professionalization challenges seen in local food businesses.

I had some concern about using case studies from a single state in the US, regardless of the ways in which the cases proved to be unalike (in size and structure, demographic situation, agricultural history, and framing). As I found my cases through inquiring among staff of cooperative food retailers, it is clear that the recommendations came from a knowledgeable community. Still, the geographical and climactic conditions of both case studies likely render their conceptions of local food to be somewhat anomalous from food co-ops in more hospitable agricultural climates, where the majority of US food co-ops are located. ${ }^{93}$

The selection of a different site may have led to opportunities to study other arrangements being used by cooperatives to engage in local food. This might particularly be the case in areas such as the Midwest, where there density of cooperative businesses is greater. This further speaks to the individuality of cooperatives and their goals and approaches not being one-size fits all - reinforcing the actor orientation of this work. Selecting cooperatives working as part of a secondary co-op system, such as the Twin Cities Cooperative Local Food System - comprising a cooperatively owned distribution hub and 15 different individual consumer cooperatives owned by 91,000 member-owners - would surely present different concerns, strategies, and impacts of the local food system. This could also be said of the UK cases which had to be abandoned in the course of this research. Given the divergent scales of cooperative retail, as well as the disparate emphases on local food provisioning between Europe and the US, a multi-country longitudinal study could be a useful tool to explicate the potential engagement

\footnotetext{
${ }^{93}$ The distribution of food co-ops in temperate growing regions is according to the Cooperative Grocer Network, comprising more than 300 retail food co-ops across the US. http://www.grocer.coop/coops
} 


\section{2 | Chapter Six}

between cooperatives and local producers - especially for such issues as market access, farmer livelihoods, and fresh food access for consumers.

\section{On methods used}

Uniform branding, corporate identities, and consistent messaging are important to businesses, even in less hierarchical models that might include cooperatives. Given that local food is a point of differentiation for the cooperatives in this research, it is logical that a roundly positive portrayal of local food and interactions around local food provisioning would be shown in their publicity materials. Though it would have been possible to conduct analyses focused on publicity material (such as web sites and social media, sales leaflets, membership materials, and monthly newsletters), doing so would not have captured the varied attitudes and experiences of the staff members working on local food. In-depth, semi-structured interviews drove this research and allowed variety and nuance to emerge among the informants. Still, the publicity materials did inform what questions I asked and my general understanding of my field sites. They also led me to inquire about specific vendors, products, and events that crucially influenced the research.

Though this research was qualitative in nature, the addition of quantitative data might also have provided further nuance to the understandings of the impacts of local food provisioning, both for the case study sites and for the local vendors who supply them. During fieldwork, I was mainly presented with estimates regarding amounts and volumes of local sales. Though more information might have been otherwise available, there did not seem to be much disaggregated data to gauge the importance of local food. Such data could be particularly useful for cooperatives interested in sourcing more local food and for regions that are interested in making the case to support local food provisioning through policy incentives and other means. There was frequent mention of a local economic multiplier effect, but (again) figures were given of national averages, which could be less relevant to the New Mexican context. Although work has been done at the Minnesota-based Crossroads Center to determine potential impacts of local food economies, there is much still be known about the local economic impact of local foods systems. 
This is due, not least to lack of agreement on standards and economic modelling assumptions, according to the USDA. ${ }^{94}$

\section{On timing}

While it is a bit of a trope to say so, more time would have allowed pursuit of various lines of inquiry that could not be followed during the official field work. Some interviews could not take place due to personal circumstances and inclement weather that made travel difficult. This mainly affected desired interviews with suppliers and staff at the outlying La Montañita locations. Also in the case of La Montañita, original fieldwork occurred during a very busy time as staff and management were pre-occupied with the opening of the newest shop location. As such, I took the opportunity to visit my other case in Las Cruces. This allowed me some focused time at the Mountain View Market field site and a new perspective upon returning to La Montañita. Still, the overall timing limited the attention staff members could offer to this research.

Although initially it emerged as a concern, the time away from the field between onsite research and write-up proved to be useful in offering some perspective regarding the possibilities of evolution and change in the framing of local food. Like embeddedness, framing proved to have a temporal constraints, partially due to the change in personnel and the influence of social relations and economic fortunes of the case studies. Additionally, the specific developments at the La Montañita case study regarding Take Back the Co-op offered a glimpse into the challenges of maintaining both a market share and social and ecological values as the retail grocery market became more competitive. Future research about the reframing of important parts of a cooperative's identity and mission could be useful for cooperatives trying to negotiate ways of doing business that might change the expression of their core values.

\subsection{1: A reflexive view on my presence as a researcher}

My experience in the field was the most exciting and energizing part of the research process, and I was enthusiastic about the work that my case study sites were undertaking. I had excellent cooperation in the field and expressed my gratitude to

\footnotetext{
${ }^{94}$ The Crossroads Resource Center's series called "Finding Food in Farm Country" offers statistical information on 40 states local farm and food economies, including New Mexico, though data are from 2009 and earlier. http:// www.crcworks.org/?submit=fffc The USDA's publication "Trends in U.S. Local and Regional Food Systems: A Report to Congress" may be found at www.ers.usda. gov/publications/apadministrative-publication/ap-068.aspx
} 


\section{$214 \mid$ Chapter Six}

my hosts. I relied on the resources of the cooperatives for internet access and work space. During most of my fieldwork, I lived with key staff members at my field sites and shared meals with them. I was dependent on them for transportation until I was able to arrange a car. Generally speaking I was fond of those whom I met and even gave one very warm and effusive staff member a hug after an interview. While these were genuine and uncalculated interactions, I am aware that they must have also influenced the sort of information I was offered.

Still, I was able to retain a critical eye. This was especially true when I found myself taken aback at things that worked differently than imagined or poorly (organizationally-speaking) in the cooperatives. In speaking to a variety of people in roles related to local food, but from very different sides, I was privy to the disparate and sometimes contradictory judgements about how well things worked with local suppliers, the autonomy of produce buyers, and misunderstandings or disagreements, both among different staff members and between staff and suppliers.

I did not tend to volunteer much about my personal background or my familiarity with the US to my informants, though I was always truthful when asked about my education or upbringing, my choice of topic, etc. This was to both limit my presumptions about the social context of this research and to allow informants to give full explanations of what they thought was important. This was also necessary, given my personal inexperience of working in retail, farming, or distribution - and unfamiliarity with the state of New Mexico.

Finally, I am aware that I did not explore issues of exclusivity, race, class, and wealth inequality more than I have touched upon in this thesis. While this allowed me to stay closer to my intended topic as formulated before going to the field, I also felt ill-equipped to take on these topics in the scope of this research. Still, I know that these issues are part of an ongoing and important critique of AFNs and an matter of concern for US-based cooperatives in the natural and organic food sector. ${ }^{95}$ Though these issues were highlighted in one particular exchange with Mountain View Market staff members, there may have been other chances to more deeply engage

\footnotetext{
${ }^{95}$ See several articles for discussions of this in the cooperative world: http://www.grocer.coop/articles/expandinghealthy-food-access-new-england-co-ops; http://www.grocer.coop/articles/cooperative-grocery-store-wantsbreak-diversity-mold; http://www.grocer.coop/articles/building-partnerships-across-race-and-class
} 
with these issues, as scholars such as Julie Guthman (2011) and Alison Hope Alkon (2008) have urged academics in the alternative food world to do.

\subsection{2: Questions for cooperatives}

Though the literature on alternative food networks, local food, and cooperatives is rather sparse, there have been some important contributions in the last few years - particularly with respect to expanding or scaling up local food provision and awareness around attendant issues. These include work by Katchova and Woods looking at competition (2013) and marketing strategies (2011); Hingley et. al (2011) examining cooperatives as potential sustainable food suppliers in the European context; and - in the Canadian context - studies of local food among conventional consumer cooperatives (Lake and Leviten-Reid 2015) and among organic ones (Sumner et al. 2014). There is an overlapping concern regarding scale that is seen in both AFNs and cooperatives. As they each get bigger, they must be concerned about staying true their missions and the possibilities of re-creating food system inequities, exploitation, and power imbalances. Indeed, as was seen in the case studies, as the scale of procurement or distribution grew, the cooperatives sometimes struggled to maintain certain ethical approaches to their work.

The requirement to have a robust democracy is an additional concern for cooperatives. Though there is a call for scaling up, what are the ramifications for democracy? How does a co-op manage to maintain participation from its communities as it gets larger? The multi-stakeholder model of cooperative is increasingly a popular model. Is there some particular potential in using such a model to expand the local food offerings in a community in ways that strengthens democracy?

These are issues that need to be explored in tandem with desires to increase cooperatives' scale, professionalization, and influence in the food system. The use of the policy governance model that proved contentious with the Take Back the Co-op movement has spread amongst cooperatives in the NCG distribution system, which accounts for about half of the retail food co-ops in the US. If, as Take Back the Co-op claims, this governance model is not supporting the democratic system that cooperatives need to function, what are the viable alternatives? This is an important issue for cooperatives to address. Democracy is a difference that makes 
cooperatives relevant in an age where the desire for cheaper food might eventually win the day.

\subsection{3: Cooperation in the digital age}

Finally, an intriguing issue that comes to light is what the cooperative economy might have to teach enterprises in the so-called "sharing" economy. Interest has grown in different forms of economic interaction, particularly since the 2008 financial crisis - spurring many people to work together, think creatively about income (Hamari et al. 2015), and find ways to consume more economically ("The rise of the sharing economy" 2013). Some of this interest is captured in the realization of planetary growth limitations, environmental crises, and climate change (Porritt 2012; Jackson 2012) - along with a recognition that goods and services are often not utilized efficiently. Also known as the collaborative economy, or collaborative consumption, "sharing economy" enterprises have some resonance with the cooperative movement in values of self-help and self-responsibility. These business use technology - through social networks, telecommunications, and online platforms to disseminate information, access services, and solve problems.

Como et al. - while acknowledging that the collaborative economy actually refers to a wide array of practices and experiences - define it as "a broad and varied group of practices and innovative models that use digital technologies to facilitate collaboration and exchange between peers, and to maximise the use of underutilised resources" $(2016,4)^{96}$. By harnessing technology to further social connectedness, early ventures in the "sharing economy" incorporated an ethos of minimizing unnecessary production and consumption, with their attendant stresses on natural resources. Such was the discourse around accommodation-sharing initiatives such as Couchsurfing.com and ridesharing services like Blablacar.com. Through peer-to-peer platforms, email lists, etc., the mid-late 2000s bought the possibility to access a variety of goods and services in ways that decreased personal material consumption: flexible but more sustainable transport options without the responsibilities of vehicle ownership; the ability to refresh one's wardrobe through online or in-person clothing swaps with minimum cost outlays; or the possibility to

\footnotetext{
${ }^{96}$ This definition was translated from an earlier study by Como et al. (2015), entitled "From the Sharing Economy to the Collaborative Economy: Impact and opportunities for the cooperative movement" but which is only available in its original Italian "Dalla Sharing Economy all'Economia Collaborativa: I'impatto e le opportunità per il mondo cooperativo. Quaderni di Unipolis. http://www.fondazioneunipolis.org/wp-content/uploads/2015/11/ Ricerca-Economia-collaborativa-e-Cooperazione.pdf
} 
find free or cheap lodging in the homes of local residents while travelling - all with an understanding of the opportunity of forging personal human connections. Now, however, the equivalents of (proto-taxi company) Uber and accommodation broker Airbnb have squarely come down on the side of the commercial, rather than their alternative capitalist or non-capitalist antecedents.

While the poster children of the collaborative economy are global multinationals Airbnb and Uber, there are also sites in the world of collaborative consumption that use platforms to connect people via local food. An Australia-based platform called Ripe Near Me allows people to source surplus homegrown produce - to be found in "backyards, frontyards [sic], balconies, roofs, vacant blocks and other empty urban space." Other platforms offer prepared food to be picked up for home consumption, or even to be eaten at people's houses like at a restaurant. One such site called Thuisafgehaald ${ }^{97}$ began in the Netherlands in 2012 and now boasts 55,000 participants (cooks and eaters) in Amsterdam alone. There are also iterations of this same enterprise serving Flanders (Belgium), Spain, Portugal, and the United States. The English-language site is self-styled as a way to meet neighbors, avoid cooking (if on desires that), and to reduce food waste.

Though it can be argued that collaborative consumption platforms have brought moderate financial windfalls to some, the significant money-makers from these ventures are the platform owners (mainly in Silicon Valley) who are able to extract payments at different steps in the processes of interaction on these apps. It is doubtful, though, what benefits this type of consumption has brought to communities as a whole. Indeed, the way that these platforms - which simply enable transactions to occur - generate and apportion value and profits to the participants involved has raised concern. The platforms' users own and provide the assets, services, and labor that constitute the value offered by these apps, all while "the deriving profits are appropriated by the restricted group of platform owners" (Como et al. 2016, 5).

\footnotetext{
${ }^{97}$ Ripe Near Me http://www.ripenear.me/ connects parties, but there is no payment mechanism that the site operates. Though there is some language about creating different paid plans in the future for users of the site, it was unclear how/if the site owners imagined it as a money-making venture. With respect to Thuisafgehaald, though there is no clear emphasis on sustainability or organic food, it is possible for people to indicate special dietary requests, which would include vegan and vegetarian food. https://www.thuisafgehaald.nl
} 


\section{8 | Chapter Six}

Scholz has also described how these platforms style themselves as technology companies, rather than labor or service brokerages; knowingly violate regulations; and then lobby to have the laws changed ${ }^{98}$ - justifying themselves by the numbers of their users who clearly value the convenience and efficiencies they offer (2016b, 7). As in the case of Uber - which has been faulted for driver exploitation - the company has also influenced the demographics of traditional service providers. Whereas the majority of Uber drivers in New York City are white, they have displaced older (often immigrant or ethnic minority) taxi operators who are typically less educated and may have fewer work opportunities (ibid, 6).

Scholz posits the idea that the negative effects of the collaborative economy can be addressed by "platform cooperativism." This means the use, the principles, and values (if not structures) of the cooperative movement - including shared ownership - can aid good governance, responsible regulation, and fairer revenue distribution (Scholz 2014). He offers examples of a stock photography web site owned by the photographers whose work and content are available there; taxi-drivers who own an app that is similar to Uber; and other possibilities for global, decentralized marketplaces to be owned by their users or service providers. Scholz has also suggested that such new cooperatives might help people for whom accessing the traditional labor market may be difficult or impossible (e.g., long-term unemployed, ex-convicts, or undocumented workers) (2016a).

Como et al. (2016) further offer that, for cooperatives, the collaborative economy could also be a driver of innovation, rather than cooperatives simply being a countervailing force against the excesses of collaborative consumption. Their survey of 38 collaborative economy projects - 11 European and 3 international - being run by (or as) cooperatives has revealed a range of approaches to using the methods of the collaborative economy in ways that preserve and further cooperative forms. If the collaborative consumption is to represent a transitionary movement rather than a blip in conceptions of consumption that reproduce neoliberal capitalism (Botsman and Rogers 2010), it is crucial to bring socially responsible and ecologically sound forms to light. Though Heinrichs (2013) highlights positive attributes (such as possibilities of furthering environmental sustainability), models of this "corporate"

\footnotetext{
${ }^{98}$ In the case of Uber, the company has staged lobby efforts on various issues in cities in the US and abroad. https://www.buzzfeed.com/carolineodonovan/uber-creepy-email-nyc-plan-to-track-rides?utm_term=. bd289pjWA\#.qdmLMBo08
} 
sharing economy that have also replicated some of the social externalities of neoliberalism. This is seen starkly in the deleterious effects of short-term housing rentals via Airbnb on residential housing markets in urban communities. ${ }^{99}$ With the possibilities for scalability and reach of these platforms, it is all the more important to consider how we can build economies that value the earth and the life on it.

${ }^{99}$ See https://www.theguardian.com/cities/2016/oct/06/the-airbnb-effect-amsterdam-fairbnb-property-pricescommunities for an example of an initiative to address the consequences of the high numbers of Airbnb users in Amsterdam. 


\section{Appendices}

Appendix 1: The Seven Principles of Co-operative Identity ............................. 222

Appendix 2: Primary Informants of La Montañita .......................................... 223

Appendix 3: Primary Informants of Mountain View Market ............................. 224

Appendix 4: Business strategies for local food - co-ops versus other grocers .... 225 
Appendix 1: The Seven Principles of Co-operative Identity

1st Principle: Voluntary and Open Membership

Co-operatives are voluntary organizations, open to all persons able to use their services and willing to accept the responsibilities of membership, without gender, social, racial, political or religious discrimination.

2nd Principle: Democratic Member Control

Co-operatives are democratic organizations controlled by their members. Members have equal voting rights (one member, one vote).

3rd Principle: Member Economic Participation

Members contribute equitably to the capital of their co-operative. Surpluses are allocated along defined guidelines benefitting members in proportion to their transactions with the co-operative or by supporting other activities approved by members.

4th Principle: Autonomy and Independence

Co-operatives are autonomous, self-help organizations controlled by their members. If they enter into agreements with or raise capital from external actors, they do so on terms ensuring democratic control by members.

5th Principle: Education, Training and Information

Co-operatives provide education and training for their members, elected representatives, managers, and employees. They inform the general public particularly young people and opinion leaders - about the nature and benefits of co-operation.

6th Principle: Co-operation among Co-operatives

Co-operatives serve their members and strengthen the co-operative movement by working together through local, national, regional and international structures.

7th Principle: Concern for Community

Co-operatives work for the sustainable development of their communities through policies approved by their members. 


\section{Appendix 2: Primary Informants of La Montañita}

The following is a description of the main informants I interviewed. All had job responsibilities that fell within the four areas of work espoused by La Montañita's Long Term Strategic Plan: distribution, market expansion, producer coordination and support, and local brand development. In addition to these, I also interviewed vendors and producers supplying to La Montañita, local community officials in government and non-profit organizations, and hospitality industry customers of the Co-op.

\begin{tabular}{|c|c|}
\hline $\begin{array}{l}\text { The General Manager } \\
\text { (GM) }\end{array}$ & $\begin{array}{l}\text { Responsible for the overall management of La Montañita's retail and } \\
\text { distribution divisions and reports to the Board of Directors. This person } \\
\text { oversees strategic planning and visioning regarding the growth and } \\
\text { development of the Co-op, as well as its financial profitability. I spoke to } \\
\text { both the GM in post at the time of fieldwork and the one in post at the } \\
\text { creation of La Montañita's } 20 \text {-year plan focusing on local food initiative. }\end{array}$ \\
\hline $\begin{array}{l}\text { The Membership and } \\
\text { Outreach }\end{array}$ & $\begin{array}{l}\text { Responsible for a myriad of projects around member cultivation and } \\
\text { stewardship, annual meetings and annual elections, communications. } \\
\text { There are two staff members, and they also handle community } \\
\text { engagement, education, and the Co-ops' many charitable and volunteer } \\
\text { projects. }\end{array}$ \\
\hline $\begin{array}{l}\text { The Co-op } \\
\text { Distribution Center } \\
\text { (CDC) staff }\end{array}$ & $\begin{array}{l}\text { The Warehouse Manager (CDC-WM) handled operations, purchasing } \\
\text { through a national distributor for "natural and organic food, purchasing } \\
\text { from medium-sized local producers, and cultivating specialty programs } \\
\text { for local meat cheese. The Purchaser (CDC-P) handled special product } \\
\text { accounts, especially a large organic dairy products co-op called Organic } \\
\text { Valley. The Outside Sales Representative (CDC-SR) worked with } \\
\text { institutional customers, particularly in the restaurant and hospitality } \\
\text { sector. In addition, there are } 2 \text { truck drivers and 3-4 warehouse staffers. }\end{array}$ \\
\hline $\begin{array}{l}\text { The Business } \\
\text { Enterprise } \\
\text { Development } \\
\text { Coordinator (BEDC) }\end{array}$ & $\begin{array}{l}\text { Provided advice to the Co-op's local vendors to help bolster a regional } \\
\text { food system by addressing specific challenges that often destabilized small } \\
\text { producers. }\end{array}$ \\
\hline $\begin{array}{l}\text { The Marketing } \\
\text { Coordinator }\end{array}$ & $\begin{array}{l}\text { The marketing department designs and produces marketing and } \\
\text { communication materials - including, websites, videos, and still } \\
\text { imagery - and the all elements of the graphic identity for the Co-op. This } \\
\text { department has also supported local vendors in producing graphic identity } \\
\text { and marketing materials for their own co-op and food-related businesses. }\end{array}$ \\
\hline $\begin{array}{l}\text { The Produce } \\
\text { Manager (PM) }\end{array}$ & $\begin{array}{l}\text { At each of the La Montañita storefronts the PM manages a small team } \\
\text { with a lot of independence. I was able to interview five staff members at } \\
\text { three different locations. There had been a lot of turnover in the produce } \\
\text { departments in the years immediately prior to my fieldwork, and most } \\
\text { produce managers, who are also the produce buyers at the storefronts, } \\
\text { had been with the Co-op fewer than two years. }\end{array}$ \\
\hline
\end{tabular}




\section{Appendix 3: Primary Informants of Mountain View Market}

The following is a description of the main informants I interviewed. They all had some role in the development of Mountain View Market's capacity to offer local food for sale.

\begin{tabular}{|c|c|}
\hline $\begin{array}{l}\text { The General } \\
\text { Manager (GM) }\end{array}$ & $\begin{array}{l}\text { Responsible for the overall management of Mountain View Market Co-op } \\
\text { and Farm. Reports to the Board of Directors. This person oversees strategic } \\
\text { planning and visioning regarding the growth and development of the } \\
\text { Co-op, as well as its financial profitability. The GM in post at the time also } \\
\text { staffed at least one of two farmers' markets every week and was crucial } \\
\text { to the development and functioning of the MVM Farm. He designed and } \\
\text { built the aquaponics operation and greenhouse to offer micro-greens and } \\
\text { wheatgrass and was physically present and labored a lot on the farm. }\end{array}$ \\
\hline $\begin{array}{l}\text { The Marketing } \\
\text { Coordinator }\end{array}$ & $\begin{array}{l}\text { Responsible for special projects, merchandising and community } \\
\text { development and engagement, including classes offered in the community } \\
\text { space at the Co-op. Organized a weekly growers' market and handled the } \\
\text { first stages of recruiting local growers and suppliers to the Co-op before } \\
\text { the advent of the MVM Farm. }\end{array}$ \\
\hline $\begin{array}{l}\text { The Mountain View } \\
\text { Market Kitchen } \\
\text { Manager }\end{array}$ & $\begin{array}{l}\text { Responsible for the running of a full production kitchen and dining } \\
\text { location at the Co-op and a smaller cafe location at another site - including } \\
\text { supervising staff in both locations. Handles vendor recruitment and } \\
\text { ordering for local products in the kitchen and organizes catering work done } \\
\text { by MVM Kitchen. }\end{array}$ \\
\hline $\begin{array}{l}\text { The Mountain View } \\
\text { Market Farm staff } \\
\text { (three people) }\end{array}$ & $\begin{array}{l}\text { Farm Manager and Farm Assistant are responsible for almost all the same } \\
\text { tasks, with some exceptions taken on solely by the Manager: Animal } \\
\text { husbandry (chickens, worms, pigs, and fish), planting, composting, plan- } \\
\text { ning, weeding, managing volunteers, and harvesting crops twice weekly. } \\
\text { Prepping crops for two farmers' markets, the Co-op produce department, } \\
\text { restaurant sales, and some CSA boxes. } \\
\text { Farm Administrator handled record keeping and administration, } \\
\text { fundraising, volunteer recruitment and training, reporting to the Board, } \\
\text { developing community (and institutional sales) contacts, and liaising } \\
\text { between the Farm and the Co-op's produce department. }\end{array}$ \\
\hline $\begin{array}{l}\text { The Produce } \\
\text { Manager (PM) }\end{array}$ & $\begin{array}{l}\text { Manages a small team for the produce department but recently recruited } \\
\text { to manage the cheese and meat departments of the Co-op at the same } \\
\text { time. Approves ordering from Co-op's main produce supplier in California } \\
\text { and liaises with the MVM Farm Administrator. }\end{array}$ \\
\hline $\begin{array}{l}\text { The Online Sales } \\
\text { Manager }\end{array}$ & $\begin{array}{l}\text { Manages the online ordering and delivery for MVM Co-op and coordinates } \\
\text { with Albuquerque-based farmers markets and the MVM Farm to deliver } \\
\text { products to El Paso customers and rural communities in NM }\end{array}$ \\
\hline
\end{tabular}


Appendix 4: Business strategies for local food - co-ops versus other grocers

\begin{tabular}{|c|c|c|c|c|}
\hline \multirow[b]{2}{*}{ Business strategy } & \multicolumn{2}{|l|}{ Frequency of use $\mathrm{e}^{\mathrm{a}}$} & \multicolumn{2}{|c|}{ Competitive advantages $^{b}$} \\
\hline & $\begin{array}{l}\text { Percent of co-ops } \\
\text { reporting intensive } \\
\text { use }\end{array}$ & Rank $^{c}$ & $\begin{array}{l}\text { Percent of } \\
\text { co-ops reporting } \\
\text { advantages }\end{array}$ & Rank $^{c}$ \\
\hline Price negotiation & $39: 0$ & 7 & 45.8 & 10 \\
\hline Lower margin for local & $49: 2$ & 2 & 36.8 & 12 \\
\hline Quality negotiation & $49: 1$ & 3 & 50.8 & 8 \\
\hline Delivery/logistics coordination & $53: 4$ & 1 & 57.6 & 4 \\
\hline $\begin{array}{l}\text { Local merchandising material } \\
\text { design }\end{array}$ & $39: 7$ & 5 & 51.7 & 7 \\
\hline Volume planning & $39: 7$ & 6 & 35.1 & 14 \\
\hline Packaging design & $6: 8$ & 16 & 21.1 & 18 \\
\hline Food safety/quality assurance & $35: 6$ & 8 & 33.9 & 15 \\
\hline Planning merchandising events & $40: 7$ & 4 & 63.2 & 3 \\
\hline In-store farmer sampling & $33: 9$ & 9 & 70.7 & 1 \\
\hline Local producer rights advocacy & $12: 1$ & 13 & 54.7 & 6 \\
\hline New product development & $8: 8$ & 15 & 35.7 & 13 \\
\hline Assistance with farmer loans & $0: 0$ & 18 & 27.3 & 16 \\
\hline Farm production planning & $23: 7$ & 11 & 46.4 & 9 \\
\hline Annual producer group meetings & $17: 9$ & 12 & 57.1 & 5 \\
\hline Farmer co-op development & $1: 8$ & 17 & 70.7 & 2 \\
\hline Vendor-managed inventory & $9: 4$ & 14 & 43.4 & 11 \\
\hline Farm visits & $28: 8$ & 10 & 22.6 & 17 \\
\hline
\end{tabular}

a Food co-op managers reported the frequency of use for various business strategies: minimal, occasional, frequent, and extensive. Intensive use is defined as the sum for the categories frequent and extensive

b Food co-op managers reported the competitive advantages (five categories: major disadvantage, slight disadvantage, no difference, slight advantage, major advantage) they perceive they have over other grocers when using these business strategies. Competitive advantage is the sum of slight advantage and major advantage categories

c Rank was assigned after sorting the strategies from most to least in terms of frequency or competitive advantage and assigning ranks

Source: (Katchova and Woods 2013, 21) 


\section{References}

Alkon, A. H. 2008. From value to values: sustainable consumption at farmers markets. Agriculture and Human Values 25 (4): 487-498. http: //dx.doi.org/10.1007/s10460-008-9136-y.

Allen, P. 2010. Realizing justice in local food systems. Cambridge J ournal of Regions, Economy and Society 3 (2): 295-308. http://dx.doi. org/10.1093/cjres/rsq015.

Amin, A., A. Cameron, and R. Hudson. 2002. Placing the Social Economy. London: Routledge.

Amin, A., and N. Thrift. 1995. "Globalisation, institutional thickness and the local economy." In Managing cities: The new urban context, edited by P. Healey, S. Cameron, S. Davaoudi, C. Graham and A. Madani-Pour, 91-108. Chichester, New York.

Amin, S. 2011. "Food Sovereignty: A struggle for convergence in diversity." In Food Movements Unite!: Strategies to Transform Our Food Systems, 348-348. Oakland: Food First Books.

Angrosino, M. V., and K. A. Mays de Pérez. 2000. "Rethinking observation: From method to context." In Handbook of Qualitative Research, 673-702. Sage.

Arce, A. 1997. Globalization and food objects. International Journal of Sociology of Agriculture and Food 6: 77-107.

Bacon, C. M. 2010. Who decides what is fair in fair trade? The agrienvironmental governance of standards, access, and price. Journal of Peasant Studies 37 (1): 111-147. http://dx.doi. org/10.1080/03066150903498796.

Barker, E., A. Voinea, and A. Murray. 2012. Co-operatives Build a Better World Through Food. Manchester: Co-operative News. Available from http://ica.coop/sites/default/files/publication-files/ fooden0-1077165192.pdf [Accessed March 2017].

Barnett, C., N. Clarke, P. Cloke, and A. Malpass. 2005. The political ethics of consumerism. Consumer Policy Review 15 (2): 45-51. 
Battilani, P., and H. G. Schröter. 2012. "Conclusion: The Decisive Factors of Cooperatives' Future - Their Nature, Longevity, Role, and Environment." In The Cooperative Business Movement, 1950 to the Present, edited by Patrizia Battilani and Harm G Schröter. New York: Cambridge University Press.

Beckert, J. 2007. The Great Transformation of Embeddedness: Karl Polanyi and the New Economic Sociology. Cologne: Max-Planck-Institut für Gesellschaftsforschung. Available from http://www.mpifg.de/pu/ mpifg_dp/dp07-1.pdf [Accessed March 2017].

Belasco, W. J. 2007. Appetite for Change: How the counterculture took on the food industry. Ithaca: Cornell University Press.

Bioneers. n.d. Dreaming New Mexico:An Age of Local Foodsheds and a Fair Trade State. Santa Fe, New Mexico: Collective Heritage Institute. Available from http://www.dreamingnewmexico.org/ files/ DNMAgeofLocalFoodshedsandAFairTradeStateBooklet. pdf [Accessed March 2017].

Birchall, J. 1994. Co-op: the people's business. Manchester: Manchester University Press.

-_- 1997. The International Co-operative Movement. Manchester: Manchester University Press.

Block, F. 1990. Postindustrial possibilities: A critique of economic discourse. Berkeley: University of California Press.

- - . 2001. "Introduction to Polanyi's The Great Transformation." In The Great Transformation: The Political and Economic Origins of Our Time, xxviii-xxxviii. Boston: Beacon Press.

Bonanno, A., L. Busch, and W. H. Friedland. 1994. From Columbus to ConAgra: the globalization of agriculture and food. Rural America. Lawrence: University Press of Kansas.

Bonin, J. P., D. C. J ones, and L. Putterman. 1993. Theoretical and empirical studies of producer cooperatives: will ever the twain meet? J ournal of Economic Literature 31 (3): 1290-1320.

Botsman, R., and R. Rogers. 2010. Beyond zipcar: Collaborative consumption. Harvard Business Review 88 (10): 30.

Bowen, S. 2011. The Importance of Place: Re-territorialising Embeddedness. Sociologia Ruralis 51 (4): 325-348. 
Brunori, G., A. Rossi, and V. Malandrin. 2011. Co-producing transition: Innovation processes in farms adhering to solidarity-based purchase groups (GAS) in Tuscany, Italy. International Journal of Sociology of Agriculture and food 18 (1): 28-53.

Cameron, J., and K. Gibson. 2001. "Regional communities reinvent economy." In All change!: Gippsland perspectives on regional Australia in transition, edited by Jacqui Dibden, Meredith Fletcher and Chris Cocklin. Melbourne: Monash Regional Australia Project.

Campbell, H. 2016. In the long run, will we be fed? Agriculture and Human Values 33 (1): 215-223.

Caraher, M., J. Smith, and G. Machell. 2015. To co-op or not to co-op: a case study of food co-ops in England. Journal of Co-operative Studies 47 (2): 6-19.

Chyi, H. I., and M. McCombs. 2004. Media salience and the process of framing: Coverage of the Columbine school shootings. Journalism \& Mass Communication Quarterly 81 (1): 22-35.

Co-operatives UK. 2009. Simply Legal. Manchester. Available from https:// www.uk.coop/sites/default/files/uploads/attachments/simplylegal-updated-jun-2016. pdf [Accessed March 2017].

-_-. 2012. The UK co-operative economy 2012: Alternatives to austerity. Manchester. Available from http://community-wealth. $\mathrm{org} / \mathrm{sites} /$ clone. community-wealth.org/files/downloads/reportco-operativesUK.pdf [Accessed March 2017].

Como, E., A. Mathis, M. Tognetti, and A. Rapisardi. 2016. Cooperative Platforms in a European Landscape: An Exploratory Study. In International Social Innovation Research Conference (ISIRC). Glasgow. Available from https://coopseurope.coop/sites/ default/files/Paper_Cooperatives\%20Collab\%20Economy__.pdf [Accessed March 2017].

Cox, R., L. Holloway, L. Venn, L. Dowler, J. R. Hein, M. Kneafsey, and H. Tuomainen. 2008. Common ground? Motivations for participation in a community-supported agriculture scheme. Local Environment 13 (3): 203-218.

Crabtree, T., K. Morgan, and R. Sonnino. 2012. Prospects for the Future: Scaling Up the Community Food Sector. Woodstock: Making Local Food Work. Available from https: //www. siceurope.eu/sites/ default/ files/field/attachment/MLFW\%20final\%20report.pdf [Accessed March 2017]. 
Day-Farnsworth, L., B. McCown, M. Miller, and A. Pfeiffer. 2009. Scaling Up: Meeting the Demand for Local Food. University of WisconsinExtension Agricultural Innovation Center, University of Wisconsin Center for Integrated Agricultural Systems. Available from http:// www. cias.wisc.edu/wp-content/uploads/2010/01/baldwin_web_ final.pdf [Accessed March 2017].

Deller, S., A. Hoyt, B. Hueth, and R. Sundaram-Stukel. 2009. Research on the economic impact of cooperatives. In University of Wisconsin Center for Cooperatives. Available from http://reic. uwcc. wisc. edu/ sites/all/REIC_FINAL.pdf [Accessed March 2017].

Denzin, N. K., and Y. S. Lincoln. 2000. "The discipline and practice of qualitative research." In Handbook of Qualitative Research, 1-28. Sage.

Dewulf, A., B. Gray, L. Putnam, R. Lewicki, N. Aarts, R. Bouwen, and C. van Woerkum. 2009. Disentangling approaches to framing in conflict and negotiation research: A meta-paradigmatic perspective. Human Relations 62 (2): 155-193.

DuPuis, E. M., and D. Goodman. 2005. Should we go "home" to eat?: toward a reflexive politics of localism. Journal of Rural Studies 21 (3): 359-371. http://dx.doi.org/10.1016/j.jrurstud.2005.05.011.

DuPuis, E. M., D. Goodman, and J. Harrison. 2006. Just Values or Just Value? Remaking the Local in Agro-Food Studies. Research in Rural Sociology and Development 12 (06): 241-268. http://dx.doi. org/10.1016/s1057-1922(06)12010-7.

Ekberg, E. 2012. Confronting three revolutions: Western European consumer co-operatives and their divergent development, 19502008. Business History 54 (6): 1004-1021.

Entman, R. M. 1993. Framing: Toward Clarification of a Fractured Paradigm. J ournal of communication 43 (4): 51-58.

Euricse. 2016. World Co-operative Monitor: Exploring the Co-operative Economy. Euricse. Available from http://ica.coop/sites/default/ files/WCM_2016.pdf?_ga=1.149123248.727338043.1488831351 [Accessed March 2017].

European Commission. 2017. Social Economy in the EU. Available from http://ec.europa.eu/growth/sectors/social-economy_en [Accessed March 2017]. 
Fairbairn, B. 2001. Social Movements and Co-opertives: Implications for History and Development. Review of International Co-operation 94 (1): 24-34.

FAO. 2009. 1.02 billion people hungry. Available from http://www.fao. org/news/story/en/item/20568/icode/ [Accessed March 2017].

Feenstra, G. 2002. Creating space for sustainable food systems: Lessons from the field. Agriculture and Human Values 19 (2): 99-106.

Fenton, C., and A. Langley. 2011. Strategy as practice and the narrative turn. Organization Studies 32 (9): 1171-1196.

Friedmann, H. 1987. "International regimes of food and agriculture since 1870." In Peasants and peasant societies : selected readings, edited by T. Shanin. Oxford: Blackwell.

- - . 1993a. The political economy of food: a global crisis. New Left Review 197: 29-57.

- - . 1993b. The regulation of international markets: the unresolved tension between national states and transnational accumulation. IDS Bulletin 24 (3): 49-53.

- - . 2005. "From Colonialism to Green Capitalism: Social Movements and Emergence of Food Regimes." In New Directions in the Sociology of Global Development, edited by F. H. Buttel and P. McMichael, 227-264. Emerald Publishing Group.

- - - 2007. Scaling up: Bringing public institutions and food service corporations into the project for a local, sustainable food system in Ontario. Agriculture and Human Values 24 (3): 389-398. http:// dx.doi.org/10.1007/s10460-006-9040-2.

- - . 2013. Food soverignty: A critical dialogue. Paper read at Beyond the Price Paradox: Towards Deepening the Ecological/Material Foundations of Alliances Across the Food System, 14 September 2013, at Yale University.

- - - 2016. Commentary: Food regime analysis and agrarian questions: widening the conversation. The Journal of Peasant Studies 43 (3): 671-692. http://dx. doi.org/10.1080/03066150.2016.1146254.

Friedmann, H., and P. McMichael. 1989. Agriculture and the state system: the rise and decline of national agricultures, 1870 to the present. Sociologia Ruralis 29 (2): 93-117. 
Geertz, C. 1973. “Thick description: toward an interpretive theory of culture." In The interpretation of cultures: selected essays, 3-30. New York, : Basic Books.

Ghosh, J. 2010. The unnatural coupling: Food and global finance. Journal of Agrarian Change 10 (1): 72-86.

Gibson-Graham, J. K. 2006a. The End Of Capitalism (As We Knew It): A Feminist Critique of Political Economy; with a New Introduction. Minneapolis: University of Minnesota Press.

- - 2006b. A postcapitalist politics. Minneapolis: University of Minnesota Press.

- - . 2008. Diverse economies: performative practices for 'other worlds'. Progress in Human Geography 32 (5): 613-632. http://dx.doi. org/10.1177/0309132508090821.

-- - 2014. Rethinking the Economy with Thick Description and Weak Theory. Current Anthropology 55 (S9): S147-S153. http://dx.doi. org/10.1086/676646.

Gibson-Graham, J. K., J. Cameron, and S. Healy. 2013. Take back the economy: an ethical guide for transforming our communities. Environmental Education Research. Minneapolis: University of Minnesota Press.

Gibson-Graham, J. K., A. Hill, and L. Law. 2016. Re-embedding economies in ecologies: resilience building in more than human communities. Building Research \& Information 44 (7): 703-716. http://dx.doi.or g/10.1080/09613218.2016.1213059.

Gibson-Graham, J. K., and G. Roelvink. 2009. "Social innovation for community economies." In Social Innovation and Territorial Development, edited by D MacCallum, Frank Moulaert, J. Hillier and S. Vicari Haddock, 25-37. New York: Ashgate Publishing.

Gibson, K. 2016. Lecture: Take Back the Economy! An Ethical Guide for Transforming Our Communities. Paper read at WTM Forum 1: Commoning Economy, 17 January 2016, at Utrecht, the Netherlands.

Girard, J., and G. Langlois. 2009. "Solidarity Co-operatives (Quebec, Canada)." In The Changing Boundaries of Social Enterprises, edited by A. Noya, 229-272. Paris: OECD Publishing. 
Granovetter, M. 1985. Economic Action and Social Structure: The Problem of Embeddedness. American J ournal of Sociology 91 (3): 481-510. http://dx.doi.org/10.2307/2780199.

Gray, D. E. 2004. Doing research in the real world: Qualitative and quantitative approaches. Thousand Oaks, California: Sage Publications Inc.

Groves, F. 1985. What is cooperation?: The philosophy of cooperation and it's relationship to cooperative structure and operations. In UWCC Occasional Paper. Madison: University Center for Cooperatives, University of Wisconsin--Extension. Available from http://www. uwcc. wisc.edu/info/ocpap/groves. html [Accessed March 2017].

Guthman, J. 2008. "If They Only Knew": Color Blindness and Universalism in California Alternative Food I nstitutions. The Professional Geographer 60 (3) : 387-397. http://dx. doi.org/10.1080/00330120802013679.

- - . 2011. "If they only knew: The unbearable whiteness of alternative food." In Cultivating Food J ustice: Race, Class and Sustainability, edited by AH Alkon and J Agyeman, 263-281. Cambridge, Massachusetts: M.I.T. Press,.

Hamari, J., M. Sjöklint, and A. Ukkonen. 2015. The sharing economy: Why people participate in collaborative consumption. Journal of the Association for Information Science and Technology.

Hassanein, N. 2003. Practicing food democracy: a pragmatic politics of transformation. Journal of Rural Studies 19 (1): 77-86. http:// dx.doi.org/10.1016/s0743-0167(02)00041-4.

Hatanaka, M., and L. Busch. 2008. Third-Party Certification in the Global Agrifood System: An Objective or Socially Mediated Governance Mechanism? Sociologia Ruralis 48 (1): 73-91.

Heinrichs, H. 2013. Sharing economy: a potential new pathway to sustainability. Gaia 22 (4): 228.

Hess, M. 2004. 'Spatial'relationships? Towards a reconceptualization of embeddedness. Progress in Human Geography 28 (2): 165-186.

Hill, R., and T. Myatt. 2010. The economics anti-textbook. London: Zed Books.

Hingley, M. 2010. Networks in Socially Embedded Local Food Supply: The Case of Retailer Co-operatives. Journal of Business Market 
Management 4 (3): 111-128. http://dx.doi.org/10.1007/s12087010-0036-2.

Hingley, M., M. Mikkola, M. Canavari, and D. Asioli. 2011. Local and Sustainable Food Supply: The Role of European Retail Consumer Co-operatives. International J ournal of Food System Dynamics 2 (4): 340-356.

Hinrichs, C. 2000. Embeddedness and local food systems: notes on two types of direct agricultural markets. Journal of Rural Studies 16 (3): 295-303.

- - . 2003. The practice and politics of food system localization. Journal of Rural Studies 19 (1): 33-45. http://dx.doi.org/10.1016/s07430167(02)00040-2.

Hirtz, F. 1998. The Discourse That Silences: Beneficiaries' ambivalence towards redistributive land reform in the Philippines. Development and Change 29 (2): 247-275.

Holloway, L., and M. Kneafsey. 2004. Producing-consuming food: Closeness, connectedness and rurality in four 'alternative' food networks. Geographies of rural cultures and societies: 262-282.

Holt-Giménez, E., and R. Patel. 2009. Food rebellions: Crisis and the hunger for justice. Cape Town: Pambazuka Press.

Holt-Giménez, E., and A. Shattuck. 2011. Food crises, food regimes and food movements: rumblings of reform or tides of transformation? The J ournal of Peasant Studies 38 (1): 109-44. http://dx.doi.org/ $10.1080 / 03066150.2010 .538578$.

How to do a frame analysis of news media. 2009. In Sociology of News 196b: University of Vermont. Available from http://www.uvm. edu/ tstreete/Courses/sociology_of_news/page25/page25.html [Accessed March 2017].

Hsu, J.-Y., and A. Saxenian. 2000. The limits of guanxi capitalism: transnational collaboration between Taiwan and the USA. Environment and Planning A 32 (11): 1991-2005.

Hudson, R. 2009. Life on the edge: navigating the competitive tensions between the 'social' and the 'economic' in the social economy and in its relations to the mainstream. Journal of Economic Geography 9 (4): 493-510. http://dx.doi.org/10.1093/jeg/lbp005. 
Hueth, B., and A. Reynolds. 2011. A Life-cycle Perspective on Governing Cooperative Enterprises in Agriculture. In Choices: The Magazine of Food, Farm, and Resource Issues. Available from http://www. choicesmagazine.org/choices-magazine/theme-articles/criticalissues-for-agricultural-cooperatives/a-life-cycle-perspectiveon-governing-cooperative-enterprises-in-agriculture- [Accessed March 2017].

Ilbery, B., and M. Kneafsey. 2000. Producer constructions of quality in regional speciality food production: a case study from south west England. Journal of Rural Studies 16 (2): 217-230. http://dx. doi. org/10.1016/s0743-0167(99)00041-8.

International Co-operative Alliance. 1995. Statement on the Co-operative Identity. Available from http://www.ica.coop/coop/principles. html [Accessed March 2017].

Jackson, T. 2012. Prosperity without Growth: Economics for a Finite Planet. New York: Routledge.

Jessop, B. 2001. "The Social Embeddedness of the Economy and its Implications for Economic Governance." In The Socially Embedded Economy, edited by Fikret Adaman and Pat Devine. Montreal: Black Rose Books.

Jochnowitz, E. 2001. Edible Activism: Food, Commerce, and the Moral Order at the Park Slope Food Coop. Gastronomica 1 (4): 56-63. http://dx. doi.org/10.1525/gfc.2001.1.4.56.

Johnston, J. 2008. The citizen-consumer hybrid: ideological tensions and the case of Whole Foods Market. Theory and Society 37 (3): 229270. http://dx. doi.org/10.1007/s11186-007-9058-5.

J ohnston, J., A. Biro, and N. MacKendrick. 2009. Lost in the Supermarket: The Corporate-Organic Foodscape and the Struggle for Food Democracy. Antipode 41 (3): 509-532. http://dx.doi.org/10.1111/ j.1467-8330.2009.00685.x.

Jupp, V. 2006. The Sage dictionary of social research methods. Thosand Oaks, California: Sage.

Katchova, A. L., and T. A. Woods. 2011. The effectiveness of local food marketing strategies of food cooperatives. In AAEA \& NAREA J oint Annual Meeting. Pittsburgh. Available from https://core.ac.uk/ download/pdf/6551317. pdf [Accessed March 2017]. 
-_-. 2013. "Local Foods and Food Cooperatives: Ethics, Economics and Competition Issues." In The Ethics and Economics of Agrifood Competition, 227-242. Springer.

King, C. A. 2008. Community Resilience and Contemporary Agri-Ecological Systems : Reconnecting People and Food, and People with People. Systems Research and Behavioral Science 25 (2): 111-124. http:// dx.doi.org/10.1002/sres.

Krippner, G. R. 2001. The Elusive Market: Embeddedness and the Paradigm of Economic Sociology. Theory and society 30 (6): 775-810.

Krippner, G. R., and A. S. Alvarez. 2007. Embeddedness and the intellectual projects of economic sociology. Annual Review of Sociology 33: 219-240.

Krippner, G. R., M. Granovetter, F. Block, N. Biggart, T. Beamish, Y. Hsing, G. Hart, et al. 2004. Polanyi symposium: a conversation on embeddedness. Socio-economic review 2 (1): 109-135.

Kumar, R. 2011. Research Methodology: A Step-by-Step Guide for Beginners. Third ed. London: SAGE Publications.

Lake, A., and C. Leviten-Reid. 2015. Conventional Consumer Cooperatives and Local Foods: A Case Study from Cape Breton, Canada. J ournal of Entrepreneurial and Organizational Diversity 4 (1): 11-27.

Lang, T. 1998. Towards a food democracy. Consuming passions: Cooking and eating in the age of anxiety, ed. S. Griffiths and J. Wallace: 13-24.

- - - 2007. Food security or food democracy? In Pesticides News. London: Pesticide Action Network.

- - . 2010. Crisis? What Crisis? The Normality of the Current Food Crisis. Journal of Agrarian Change 10 (1): 87-97. http://dx.doi. org/10.1111/j.1471-0366.2009.00250.x.

Lang, T., and M. Heasman. 2004. Food wars: the global battle for mouths, minds and markets. London: Earthscan.

Lawless, G. 2003. Historic Foundations of Cooperative Philosophy. Madison: University of Wisconsin-Extension. Available from http:// www.uwcc.wisc.edu/pdf/Bulletins/bulletin_09_03.pdf [Accessed March 2017]. 
Le Heron, R. 2003. Creating food futures: reflections on food governance issues in New Zealand's agri-food sector. J ournal of Rural Studies 19 (1): 111-125. http://dx.doi.org/10.1016/s0743-0167(02)000426.

Levkoe, C. Z. 2006. Learning Democracy Through Food J ustice Movements. Agriculture and Human Values 23 (1): 89-98. http://dx.doi. org/10.1007/s10460-005-5871-5.

Little, R., D. Maye, and B. Ilbery. 2010. Collective purchase: moving local and organic foods beyond the niche market. Environment and Planning A 42 (8): 1797-1813. http://dx.doi.org/10.1068/a4262.

Lockie, S. 2008. Responsibility and agency within alternative food networks: assembling the "citizen consumer". Agriculture and Human Values 26 (3): 193-201. http://dx.doi.org/10.1007/s10460-008-9155-8.

Long, N. 1990. From Paradigm Lost to Paradigm Regained? The Case for an Actor-oriented Sociology of Development. Revista Europea de Estudios Latinoamericanos y del Caribe / European Review of Latin American and Caribbean Studies (49): 3-24. http://dx.doi. org/ $10.2307 / 25675467$.

-_-. 2001. Development sociology: actor perspectives: Routledge.

Long, N., and D. Cruz. 2003. An actor-oriented approach to development intervention. Paper read at Rural life improvement in Asia. Report of an APO Seminar on Rural Life Improvement for Community Development held in Japan, 22-26 April 2002.

Low, S. A., A. Adalja, E. Beaulieu, N. Key, S. Martinez, A. Melton, A. Perez, et al. 2015. Trends in US Local and Regional Food Systems: Report to Congress. Washington, DC: US Department of Agriculture. Available from https://www.ers.usda.gov/publications/pubdetails/?pubid=42807 [Accessed March 2017].

Lowery, M. 2010. On the Shoulders of Giants. In Management quarterly: MQ: National Rural Electric Cooperative Association.

Lune, H., E. S. Pumar, and R. Koppel. 2010. Perspectives in Social Research Methods and Analysis: A Reader for Sociology: Sage.

Magdoff, F., J. B. Foster, and F. H. Buttel. 2000. Hungry for profit: the agribusiness threat to farmers, food, and the environment: Monthly Review Press. 
McLaughlin, M. 2007. Co-op members shop like it's 1993. In The Brooklyn Paper. Brooklyn, New York. Available from http://www. brooklynpaper.com/stories/30/39/30_39foodcoop.html [Accessed March 2017].

McMichael, P. 1994. The global restructuring of agro-food systems. Food systems and agrarian change. Ithaca: Cornell University Press.

- - . 2009a. A food regime analysis of the 'world food crisis'. Agriculture and Human Values 26 (4): 281-295. http://dx.doi.org/10.1007/ s10460-009-9218-5.

- - . 2009b. A food regime genealogy. Journal of Peasant Studies 36 (1): 139-169. http://dx.doi.org/10.1080/03066150902820354.

Meter, K., and J . Rosales. 2001. Finding food in farm country: The economics of food \& farming in southeast Minnesota. Available from http:// www.crcworks.org/?submit=fffc [Accessed March 2017].

Michaels, L. 2004. What's Wrong with Supermarkets? London: Corporatewatch. Available from http://www. corporatewatch. org/?lid=2604 [Accessed March 2017].

Morgan, K., T. Marsden, and J. Murdoch. 2008. Worlds of food: Place, power, and provenance in the food chain: Oxford University Press on Demand.

Mouffe, C. 2005. On the Political. New York: Routledge.

Moulaert, F., and O. Ailenei. 2005. Social economy, third sector and solidarity relations: A conceptual synthesis from history to present. Urban Studies 42 (11): 2037-2054. http://dx.doi. org/ 10.1080/00420980500279794.

Mulqueen, T. 2012. When a business isn' $t$ a business: law and the political in the history of the United Kingdom's co-operative movement. Oñati Socio-Legal Series 2 (2): 36-56.

Murdoch, J., T. Marsden, and J. Banks. 2000. Quality, nature, and embeddedness: Some theoretical considerations in the context of the food sector. Economic Geography 76 (2): 107-125.

Nestle, M. 2003. The ironic politics of obesity. Science 299 (5608): 781.

Novkovic, S. 2008. Defining the co-operative difference. The Journal of Socio-Economics 37 (6): 2168-2177. http://dx.doi.org/10.1016/j. socec. 2008.02.009. 
Nygård, B., and O. Storstad. 1998. De-globalization of food markets? Consumer perceptions of safe food: The case of Norway. Sociologia ruralis $38(1)$ : 35-53.

Peck, J. 2005. Economic sociologies in space. Journal of Economic Geography 81 (2): 129-175.

"Peer-to-peer rental: The rise of the sharing economy". 2013. In The Economist. Available from http://www.economist.com/news/ leaders/21573104-internet-everything-hire-rise-sharing-economy [Accessed March 2017].

Penker, M. 2006. Mapping and measuring the ecological embeddedness of food supply chains. Geoforum 37 (3): 368-379.

Polanyi, K. 2001. The Great Transformation: The Political and Economic Origins of Our Time. Boston: Beacon Press.

Pollan, M. 2006. The Omnivore's Dilemma: A Natural History of Four Meals: Penguin.

- - . 2010. The Food Movement, Rising. In The New York Review of Books. New York. Available from http://www. nybooks.com/ articles/2010/06/10/food-movement-rising/ [Accessed March 2017].

Porritt, J. 2012. Capitalism as if the World Matters. London: Earthscan.

Porter, M. E. 1985. Competitive advantage: creating and sustaining superior performance. New York: Free Press.

Pugh, C. E., R. Seydel, E. Cates, S. Watts, S. Rose, M. Bieri, J. Heckes, et al. 2006. Long Term Strategic Plan: Building a Sustainable Food System. Albuquerque, New Mexico: La Montanita Food Co-op.

Raynolds, L. T., D. Murray, and P. Leigh Taylor. 2004. Fair trade coffee: building producer capacity via global networks. Journal of international development 16 (8): 1109-1121.

Renting, H., T. K. Marsden, and J. Banks. 2003. Understanding alternative food networks: exploring the role of short food supply chains in rural development. Environment and Planning A 35 (3): 393-411. http: //dx.doi.org/10.1068/a3510.

Renting, H., M. Schermer, and A. Rossi. 2012. Building Food Democracy: Exploring Civic Food Networks and Newly Emerging Forms of Food 
Citizenship. International Journal of Sociology of Agriculture \& Food 19 (3).

Rochdale Society of Equitable Pioneers. 1844. Laws and Objects of the Rochdale Society of Equitable Pioneers. Available from http://www. rochdalepioneersmuseum.coop/wp-content/uploads/2014/08/ REPS-Laws-and-Objects-1844.pdf [Accessed March 2017].

Roep, D., and J. S. C. Wiskerke. 2010. On governance, embedding and marketing: reflections on the construction of alternative sustainable food networks. Journal of Agricultural and Environmental Ethics 25 (2): 205-221. http://dx.doi.org/10.1007/s10806-010-9286-y.

Rooks, G., W. Raub, R. Selten, and F. Tazelaar. 2000. How inter-firm co-operation depends on social embeddedness: A vignette study. Acta Sociologica 43 (2): 123-137.

Rosset, P. 2006. Food is different: Why we must get the WTO out of agriculture. Global issues series. London: Zed Books.

Rosset, P. 2008. Food Sovereignty and the Contemporary Food Crisis. Development 51 (4): 460-463.

Ryan, C., K. M. Carragee, and W. Meinhofer. 2001. Theory into practice: Framing, the news media, and collective action. Journal of broadcasting \& electronic media 45 (1): 175-182.

Sacks, J. 2002. The Money Trail: Measuring your impact on the local economy using LM3. London: New Economics Foundation.

Sage, C. 2003. Social embeddedness and relations of regard: alternative 'good food' networks in south-west I reland. J ournal of Rural Studies 19 (1): 47-60.

Saxenian, A. 1999. Silicon Valley's new immigrant entrepreneurs. San Francisco: Public Policy Institute of California. Available from http:// www. ppic. org/content/pubs/report/R_699ASR.pdf [Accessed March 2017].

Scheufele, D. A., and D. Tewksbury. 2007. Framing, agenda setting, and priming: The evolution of three media effects models. Journal of communication 57 (1): 9-20.

Schoenborn, A. 2011. The Right to Retail: Can localism save Britain's small retailers? London: ResPublica. Available from http://www. respublica.org.uk/our-work/publications/right-retail-can-localismsave-britains-small-retailers/ [Accessed March 2017]. 
Scholz, T. 2014. Platform cooperativism vs. the sharing economy. Medium. Available from https://medium.com/@trebors/platformcooperativism-vs-the-sharing-economy-2ea737f1b5ad\#. k9ku2e2us [Accessed March 2017].

- - 2 2016a. How Platform Cooperativism Can Unleash the Network. Berlin: re:publica. Available from https://re-publica.com/16/ session/how-platform-cooperativism-can-unleash-network [Accessed March 2017].

- - . 2016b. Platform Cooperativism. Challenging the Corporate Sharing Economy. New York: Rosa Luxemburg Stiftung. Available from http://www.rosalux-nyc.org/wp-content/files_mf/scholz_ platformcoop_5.9.2016.pdf [Accessed March 2017].

Schwartz-Shea, P., and D. Yanow. 2012. Interpretive research design : concepts and processes. Routledge series on interpretive methods. New York: Routledge.

Seufert, V., N. Ramankutty, and J. Foley. 2012. Comparing the yields of organic and conventional agriculture. Nature 485 (7397): 229-32.

Seydel, R. 2011. California Cooperative Conference Keynote Speech. Berkeley, CA. Available from https://www.youtube.com/ watch? $v=$ QgosYeNzBec [Accessed March 2017].

Seyfang, G. 2006. Ecological citizenship and sustainable consumption: Examining local organic food networks. J ournal of Rural Studies 22 (4): 383-395.

Seyfang, G., and A. Smith. 2006. Community action: A neglected site of innovation for sustainable development? : The Centre for Social and Economic Research on the Global Environment. Available from https: // www. econstor. eu/bitstream/10419/80279/1/513781323. pdf [Accessed March 2017].

Shaw, G., and A. Alexander. 2008. British co-operative societies as retail innovators: Interpreting the early stages of the self-service revolution. Business History 50 (1): 62-78.

Shuman, M. 2010. Prospectsforfood locailzation in New Mexico. Silver Spring, MD: Bioneers. Available from http://www.dreamingnewmexico. org/files/Michael\%20Shuman\%20Research\%20on\%20NM\%20 Food\%20Localization.pdf [Accessed March 2017].

Shuman, M. H., and D. Hoffer. 2007. Leakage Analysis of the Martha's Vineyard Economy: Increasing Prosperity through Greater Self- 
Reliance. In Training and Development Corporation. Washington, DC. Available from https://mvcommission.org/sites/default/files/ docs/leakagestudy.pdf [Accessed March 2017].

Smelser, N. J., and R. Swedberg. 2005. "I ntroducing Economic Sociology." In The Handbook of Economic Sociology, edited by Neil J. Smelser and Richard Swedberg, 3-25. Princeton University Press.

Smith, A. 2006. Green niches in sustainable development: the case of organic food in the United Kingdom. Environment and Planning C: Government and Policy 24 (3): 439-458.

Snow, D. A., E. B. Rochford, J r., S. K. Worden, and R. D. Benford. 1986. Frame Alignment Processes, Micromobilization, and Movement Participation. American Sociological Review 51 (4): 464-481. http://dx.doi.org/10.2307/2095581.

Sonnino, R. 2007a. Embeddedness in action: Saffron and the making of the local in southern Tuscany. Agriculture and Human Halues 24 (1): 61-74.

- - - 2007b. The power of place: embeddedness and local food systems in I taly and the UK. Anthropology of food (S2).

Sonnino, R., and T. Marsden. 2006. Beyond the divide: rethinking relationships between alternative and conventional food networks in Europe. Journal of Economic Geography 6 (2): 181-199. http:// dx.doi.org/10.1093/jeg/lbi006.

Soper, K. 2007. Re-thinking the 'Good Life': The citizenship dimension of consumerdisaffection with consumerism. J ournal ofConsumer Culture 7 (2): 205-229. http://dx.doi.org/10.1177/1469540507077681.

van der Stoep, H. 2014. Stories becoming sticky: How civic initiatives strive for connection to governmental spatial planning agendas, Wageningen University, Wageningen.

Sumner, J., J. McMurtry, and H. Renglich. 2014. Leveraging the local: Co-operative food systems and the Local Organic Foods Co-op Network in Ontario, Canada. Journal of Agriculture, Food Systems and Community Development 4 (3): 47-60.

Tankard, J. W. 2001. The empirical approach to the study of media framing. Framing public life: Perspectives on media and our understanding of the social world: 95-106. 
Tansey, G., and T. Worsley. 1995. The Food System: A Guide. London: Earthscan.

The Co-operative Commission. 2001. The Co-operative advantage: Creating a successful family of Co-operative businesses. London. Available from http://www.just-food.com/news/the-co-operativeadvantage-report-of-the-co-operative-commission_id91949.aspx [Accessed March 2017].

Thompson, D. J. 2012. Weavers of Dreams: The Founders of the Modern Cooperative Movement. Second commerative ed: Twin Pines Press, Inc.

Thompson, J., and I. Scoones. 2009. Addressing the dynamics of agrifood systems: an emerging agenda for social science research. Environmental Science \& Policy 12 (4): 386-397. http://dx.doi. org/http://dx.doi.org/10.1016/j.envsci.2009.03.001.

Thornburg, G. K., and D. Ramsey. 2013. Embeddedness, marketness, and economic instrumentalism in the Oklahoma Farm-to-School Program. Journal of Rural and Community Development 8 (3): 321-334.

Traill, W. B. 2006. The Rapid Rise of Supermarkets? Development Policy Review 24 (2): 163-174. http://dx.doi.org/10.1111/j.14677679.2006.00320.x.

Tregear, A. 2011. Progressing knowledge in alternative and local food networks: Critical reflections and a research agenda. Journal of Rural Studies 27 (4): 419-430. http://dx.doi.org/10.1016/j. jrurstud.2011.06.003.

Tregear, A., and S. Cooper. 2016. Embeddedness, social capital and learning in rural areas: The case of producer cooperatives. Journal of Rural Studies 44: 101-110. http://dx.doi.org/http://dx.doi. org/10.1016/j.jrurstud.2016.01.011.

Tremlett, G. 2013. Mondragon: Spain's giant co-operative where times are hard but few go bust. In The Guardian. London. Available from http: // www.theguardian.com/world/2013/mar/07/mondragonspains-giant-cooperative [Accessed March 2017].

Uzzi, B. 1996. The sources and consequences of embeddedness for the economic performance of organizations: The network effect. American Sociological Review: 674-698. 
Van Til, J. 1988. Mapping the third sector: Voluntarism in a changing social economy. New York: Foundation Center

Veen, E., P. Derkzen, and J. Wiskerke. 2012. Motivations, reflexivity and food provisioning in alternative food networks: case studies in two medium-sized towns in the Netherlands. International Journal of Sociology of Agriculture and Food 19 (3): 365-382.

Watts, D. C. H., B. Ilbery, and D. Maye. 2005. Making reconnections in agro-food geography: alternative systems of food provision. Progress in Human Geography 29 (1): 22-40. http://dx.doi. org/10.1191/0309132505ph526oa.

Webster, A., L. Shaw, and R. Vorberg-Rugh. 2016. Mainstreaming Co-operation: An Alternative for the Twenty-First Century? Manchester: Manchester University Press.

Weick, K. E. 1995. Sensemaking in organizations. Vol. 3. Thousand Oaks, California: Sage.

Welsh, J., and R. MacRae. 1998. Food Citizenship and Community Food Security: Lessons from Toronto, Canada. Canadian Journal of Development Studies/Revue canadienne d'études du développement 19 (4): 237-255. http://dx.doi.org/10.1080/022 55189.1998.9669786.

Werner, O., and G. M. Schoepfle. 1987. Systematic fieldwork: Foundations of ethnography and interviewing. 2 vols. Vol. 1. Sage: Newbury Park.

Whatmore, S., P. Stassart, and H. Renting. 2003. What's alternative about alternative food networks? Environment and Planning A 35 (3): 389-391. http://dx.doi.org/10.1068/a3621.

Whyman, P. B. 2012. Co-operative principles and the evolution of the 'dismal science': The historical interaction between co-operative and mainstream economics. Business History 54 (6): 833-854.

Wilkins, J. L. 2005. Eating Right Here: Moving from Consumer to Food Citizen. Agriculture and Human Values 22 (3): 269-273. http:// dx.doi.org/10.1007/s10460-005-6042-4.

Yanow, D., and P. Schwartz-Shea. 2014. Interpretation and method: empirical research methods and the interpretive turn. Armonk, NY: M.E. Sharp. 
Yin, R. K. 2009. Case Study Research: Design and Methods. 4 ed. Vol. 5. Applied Social Science Research Methods. Thousand Oaks, California: Sage.

Zeuli, K. A., and R. Cropp. 2004. Cooperatives: Principles and practices in the 21st century. Business. Madison: University of Wisconsin Cooperative Extension.

Zukin, S., and P. DiMaggio. 1990. "Introduction." In Structures of capital: The social organization of the economy, edited by Sharon Zukin and Paul DiMaggio, 1-36. Cambridge: Cambridge University Press.

Zwartkruis, J. 2013. Framing in innovation. Towards sustainable agrofood systems. Utrecht: Utrecht University. Available from https:// dspace. library.uu.nl/handle/1874/282737 [Accessed March 2017]. 
800 million people around the world belong to coI at least 100 million of them are employed by coEN THAN YOU PROBABLY REALIZE, CO-OPS PLAY A VITAL PART OF YOUR ion builds strong bonds between the people and the people who supply them, co-ops offe
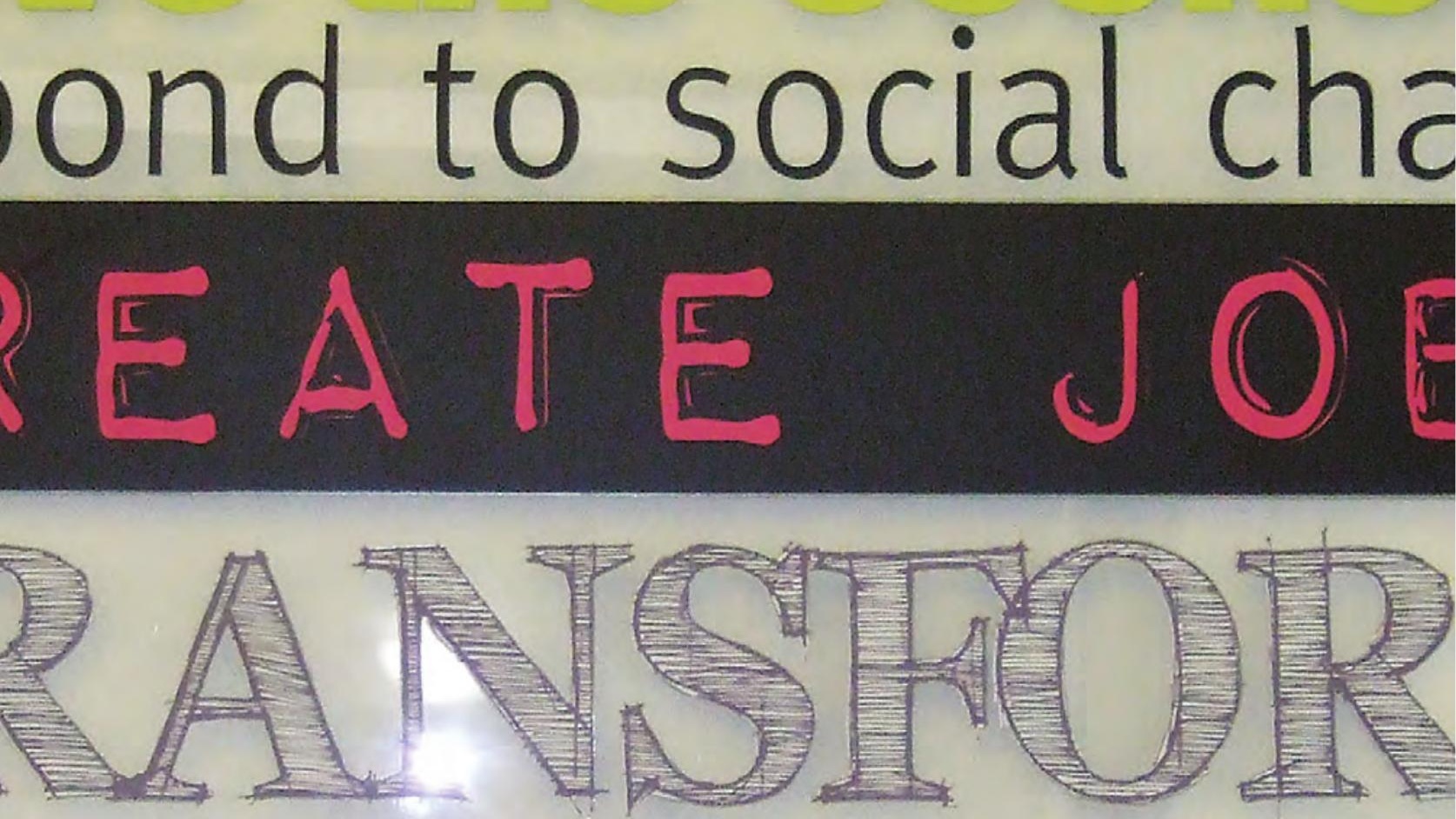

co-op. local. trustworthy. dependable history. build a better 


\section{Summary}

\section{INTRODUCTION}

The topic:

Local food has become an interest for consumers concerned with sustainability and health - and with having more control over and knowledge about their food supply. As with various food movements and campaigns that purport to be more beneficial to human, animal, or ecological health, local food is also a point of differentiation in food retailing that can serve as an economic sales niche. This has previously been seen strongly in the rise and growth of the organic food movement. Indeed, many cooperatives in the United States - where the empirical work for this research took place - have developed significant market strategies that take advantage of the burgeoning interest in local food provisioning. Though they may define local food differently in their various contexts, cooperative food retailers in the US are increasingly engaging in local food provisioning. This, however, is not a universal practice; nor is it an easy one. Foodstuffs in the US travel an average of between 1300-2200 miles from the point of production to the point of consumption, and the logistics around food provisioning are geared to this. As such, local food requires efforts that go beyond the methods used by supermarkets, large distributors, institutional buyers, and other big players in the food system. This research investigates why and how cooperative food retailers engage in local food provisioning. While local food proponents point to the possible benefits of local food - greater food security, increases in food sector related jobs, and reductions in certain environmental pollutants - this research examines the attitudes and practices of certain types of food retailers (cooperatives) with respect to local food.

The food system's inadequacies:

Alternative food movements - also referred to as alternative food networks (AFNs) or alternative agro-food networks (AAFNs) - have proliferated rapidly in many countries of the global north, where industrialization of the food system has had longest to take hold. These food movements offer a broad critique of the global food regime, and the proliferation of such movements shows the desire of groups 
and individuals to engage with the food system differently. Though characterizing alterity in the food system is contentious and not the focus of this work, Cox et al. describe AFNs as referring "to food production-consumption practices of any scale which present possibilities for producing/consuming food in ways that differ from those typical in industrialised [sic] food systems" $(2008,205)$. While, pragmatically speaking, alternative food movements are concerned with providing different ways for people to eat on a day-to-day basis, these movements also embody a desire to create structural change at different levels of the food system. As such, ideas of local participation and devolved control of food and agriculture are powerful drivers and central points of expression in the alternative food movement.

The potential contribution of cooperatives:

In diversifying and democratizing food provisioning by including different and nondominant actors, products, and ways of doing business, AFNs may bring more resilience into food systems during times of economic or environmental crisis. In the very nature of their organization, cooperatives may provide a ready outlet for manifesting different ways of production, distribution, and consumption from what is provided through the conventional, globalized food system. Cooperatives can be broadly defined as democratically-controlled enterprises that are owned by the people (or organizations) who work in or use the goods and services offered through those businesses. Through the cooperative structure (ownership by employees, customers, or a combination thereof), through the emphasis on inclusive decision making, and through applying certain principles that cooperatives agree to uphold, cooperatives offer a different model of business. It is one that exists to serve its members, rather than outside stakeholders primarily seeking profits and a return on investment.

The turn to local food:

A strategy being employed by the cooperatives in this research is a deep engagement with local food provisioning in ways that typical supermarket retailers cannot easily replicate. These cooperatives are aware of needing to promote and make the most of their differences from other food retailers. This need is as a result of the increasing availability of natural and organic food throughout the US. Where such food was once the province of cooperative food retailers, it is now widely offered at all kinds of sales outlets, including huge investor-owned firms such as WalMart. The ubiquity and the economies of scale that conventional supermarkets are 
increasingly displaying in the natural and organic food sector threaten cooperatives from a pricing standpoint. Cooperatives, however, do not behave as typical investorowned firms and may have strategic competitive advantages that they can harness to remain viable in the marketplace.

\section{RESEARCH PROCESS}

Research questions:

1) How do cooperatives frame local food?

2) What are the practices that retail food cooperatives use to engage in local food?

3) Do retail food cooperatives have a competitive advantage in local food provisioning? If so, how might that be related to the cooperative identity?

Methods and data:

I have explored these questions using two case studies of co-ops located in New Mexico, an arid state in the southwestern part of the United States on the border with Mexico. The co-ops had headquarters in Albuquerque in the northern part of the state and Las Cruces in the southern part. Though farming is challenging throughout the state - often because of wind and hailstorms, as much as water stress - the agricultural contexts are different and have their own challenges. The case studies were written based on interviews of staff members working on local food provisioning in the two cooperatives. The interviews were composed of open-ended questions and were transcribed and analyzed to help produce quite thickly described cases. The wide variety of roles my informants occupied helped to elucidate complex experiences and perceptions of local food.

Theoretical framework:

In trying to understand a cooperative's motivations for becoming involved in local food, I employ the theory of embeddedness discussed in Chapter 2. Though embeddedness has been presented in economic sociology by Karl Polayni and then Marc Granovetter to characterize the relationship between economy and society (or economic transactions and social actors), embeddedness is a concept widely used in AFN literature. In that context, it characterizes individual foods, food systems, or food production techniques as having particular or bounded connections to a territorial or geographic place or to a socio-cultural network. 
Embeddedness is enacted through attempts at food system (re)localization, which values or prioritizes various aspects of local food provisioning. The locality of food becomes a contested characteristic and subject to what Hinrichs (2003) described as "conceptual compression," a perfunctory overlaying of some characteristic onto another concept that is often related. An example of this is the presumption that local food is also organically grown.

Recognizing the somewhat unreflexive application of embeddedness in the food literature, I chose to go beyond AFN conceptions of embeddedness by revisiting its use by Granovetter and its original derivation from Polanyi. In so doing, I highlight Polanyi's fundamental appeal to engage in reformist thinking - a matter that is not served by limiting the analysis to show the social nature of economic transactions. Embeddedness itself is not enough to move that project forward. Instead, I take up Gibson-Graham's theory of diverse economies to participate in a project of reimagining the economy as an ethical space for decision-making and action - not as a logical machine over which human action has no influence. Diverse economies theorizing is an avenue to challenge the depiction of all models of exchange in terms relative to capitalism, as if it were the highest developmental stage of economy. By choosing to reframe what is happening in the economy beyond neoliberal capitalism, we can shed light on extant practices (alternative capitalist and non-capitalist) that are regenerative to our planet, as well as to the human and non-human creatures who occupy it.

\section{Methodology:}

The use of (re)framing local food, as done by the cooperatives in the case studies requires consideration of what is being framed when my informants talk about local food. I examine in Chapter $\mathbf{3}$ how the topic of conversation in discussions of "local food" may be complex. I found that when people talked about local food, they were referring to one of three subjects: the food itself; the food producers; or the co-op and its actions, history, and role in local food provisioning. It is through this framing that the co-ops justify and describe their practices around local food provisioning. This reflects the actor orientation of this research, wherein my informants are agents in interpreting and constructing their own realities. Multiple agents also operate in "multiple realities" - suggesting possibly conflicting and diverse configurations of knowledge (Long 2001, 19), thus allowing multiple frames to exist within a single organization or even within the mind of one informant. 


\section{Case studies:}

In Chapter 4, I describe the larger of my two case studies: La Montañita Food Co-op, which has six retail locations and is headquartered in Albuquerque, New Mexico. This cooperative created a comprehensive approach to local food that is based on a long-term strategic plan to create a local food economy. This work, which includes distribution, market expansion, producer coordination and support, and local brand development, reflects their experience of working with local producers for decades as both a buyer and reseller of locally-produced food. As La Montañita has framed its future viability in local sourcing, it is in the Co-op's interest to engage in practices that will help the livelihoods and sustainability of its local suppliers. This has encouraged practices throughout La Montañita that assist producers at different scales of business and that show multiple manifestations of diverse economies theory in one organization.

This case study has also highlighted some of the difficulties of local sourcing, in working with producers at varied levels of professionalization. This has put a focus on the education about local food that La Montañita must provide both to producers (regarding improving their operations and working with different market segments) and customers (regarding local food's challenges and benefits). By inhabiting this role, La Montañita acts as more than a middleman and actually facilitates a relationship of "co production" or "co sumption" described by Renting et al. (2012, 300-301), but on a scale that is much bigger than, say, a farmers' market interaction. Finally, this case study also saw some serious challenges to its operational structures in a critique of how it was enacting its cooperative principles. This is a taken as a reminder that diverse economies - of which I argue La Montañita Co-op is an example - come through negotiated processes that happen in communities. As such, they may develop from experiments that do not always work, but from which people and organizations can learn.

The Mountain View Market (MVM) case study featured in Chapter 5 discusses the development and workings of the MVM Co-op and the MVM Farm located in Las Cruces in the southern part of New Mexico. In a notable difference from La Montañita Co-op, Mountain View Market frames local food as a food security and autonomy issue. It sees its operations as vulnerable because of the distance and relative isolation from its main produce supplier (California-based Veritable Vegetable). As the agricultural enterprises in the southern part of the state are 
predominantly large, conventional, intensive systems, there seem to be fewer successful agro-ecological and organic growers who could potentially supply the Co-op. Thus, MVM Co-op began leasing agricultural land in 2011, on which it grew food to sell at local farmers' markets, as well as at the retail Co-op location.

Behind this, however, was a more ambitious intention to cultivate a local farming community, not just local food. By engaging the local community (through school and university groups, other smallholder farmers, local development organizations, and independent businesses), Mountain View Market sought to harness the interest in organic food production to increase supply and lower overall costs. This strategy garnered not only ideological support for organically grown food, but it brought volunteers giving practical support in the form of work hours. This is what I characterize as the diverse labor economy of the MVM Farm. Though the Farm could depend on contributions of labor from its local community, this was not necessarily the case when it came to purchasing the Farm's produce. MVM had to sell its produce at a farmers' markets 40 miles from Las Cruces in a community that would recognize its value, and pay for it. This issue of food costs represents an ongoing issue of local and organic food that continues to be a source of tension.

\section{DISCUSSION AND CONCLUSIONS}

I reiterate the answers to the first and second research questions in Chapter 6 by connecting and reflecting on the framings and practices seen in each of the case study chapters. The framings used by the cooperatives in this research exemplify the forms of embeddedness used in AFN literature (socio-material, territorial/spatial, ecological and network) to differentiate places and characterize them as unique. However, I see limited use in creating a typology of embeddedness, as different types often occur simultaneously and overlap.

I answer the third research question regarding competitive advantage and the cooperative identity by concluding that Principle 2 (democratic member participation) and Principle 7 (concern for the community) help undergird the competitive advantage that cooperatives can exert in local food provisioning. These factors are also coupled with matters of scale that allow for flexibility and decentralized decision-making - which large, regional and national grocery chains do not have - to bring in local product from smaller producers. Conversely, cooperatives 
also have economies of scale and procurement power that can handle significant amounts of local food that small AFNs would not be able to accommodate. As such, I argue that the application of the principles of cooperative identity and the business orientation of cooperatives offer them particular opportunities to engage with local food that are unlike those of either conventional supermarkets or alternative food initiatives. Economically successful attempts at local food provisioning thrive on social connections, which neoclassical economics would see as an impediment to the perfect competition of the market. By working with the complexities of retailing local food and interacting with small producers, cooperatives that have deep linkages with their local producer community can begin to develop local food as profitable niche. That work must have the ideological and practical (financial) support of the co-op's membership to flourish.

Reflections on theoretical contributions:

This final chapter also presents a discussion of embeddedness and diverse economies in order to understand AFNs and co-ops working on local food. While understanding the framing and practices of cooperatives is useful, the bigger lesson lies in the agency that social actors have, even in situations of power asymmetries. Despite the scale and power of the globalized food system, the cooperatives in this research have developed frames that allow them to see roles for themselves in the retail sector. These roles are predicated on cultivating the value(s) they have to offer. (In much the same way, this model can be applied to people recognizing their possibilities of creating community-based economies - which is the product of diverse economies theory.)

Though the volumes of local food represent a drop in the ocean in the overall amounts of food sold in supermarkets and retail outlets in New Mexico, local food provisioning affirms that another way is possible. The ideas of embeddedness that are seen in cooperatives engaging in local food move local food provisioning away from a notion of simple market exchange and into a space of ethical decision making that can be engaged in by communities. This process is reflected in the elaboration of a theory of diverse economies posited by J.K. Gibson-Graham. In critically looking at the constituent elements of our always socially-constructed economies and recognizing human agency, there lies the opportunity for concerted action that values humanity and the ecology of our planet. In this moment, it is critical to remember Gibson-Graham's challenge to the academic community to 
avoid the pitfalls of "capitalocentrism" and, thus, to both present and examine diverse economies more robustly. In doing so, we not only reveal what there is, but also reveal what there is to be done.

Contributions to the food literature:

Cooperatives exist in many areas of food and agriculture - along the entire food chain from farm to fork - yet, the academic literature on alternative food networks leaves cooperatives understudied. The exception lies in agricultural producer cooperatives (APCs) (e.g., dairy cooperatives), but APCs are more analogous to worker-owned cooperatives than to consumer cooperatives - the predominant cooperative form in the retail food sector. Thus, APCs have different perspectives and issues from cooperatives in food retailing. The possible connections between the alternative food literature and cooperatives are strong, however. They often share a significant overlap of concerns and conceptions about the global food system (e.g., organic production, food provenance and security, genetic modification, and corporate control).

Regarding local food, the literature on AFNs has mainly focused on farmers' markets and community-supported agriculture (CSA) operations, as these outlets are a direct market between consumers and producers. AFNs must be reflexive about moments of economic exchange that occur within their own highly socialized settings. There remain complex power dynamics, even in farmers' markets and CSA interactions that can often be idealized. By contrast, the supermarket-type experience of shopping in a cooperative may be seen as too capitalist or too corporate in its expression as a non-direct market. Relatively little work has showcased the place of retail co-ops in deepening local food provision. This is despite co-ops' interest, history, and credibility in sourcing local food and their competitive advantages in local food provisioning. This represents a blind spot in the literature on AFNs.

There are natural synergies between the values of the cooperative movement and of alternative food movements. The co-operative movement is also a longstanding and worldwide movement unto itself. Cooperatives work within capitalist environments but represent and model values that are important to much of the alternative food movement. (Ironically, I also take a moment to reiterate my disagreement with Gibson-Graham's characterization of cooperatives as non-capitalist.) While cooperatives may not sit comfortably in alternative food networks, they certainly 
exemplify initiatives that are in solidarity with AFNs. They also have the potential to further the aims of AFNs through structured approaches to sustainability and growth in ways that AFNs may struggle to do. I argue that greater interaction between researchers of alternative food networks and of cooperatives (beyond APCs) may offer helpful perspectives to their respective practitioners and theorist communities alike. 


\section{About the Author}

Prior to embarking on my PhD studies, I earned a bachelor's degree in the Growth and Structure of Cities from Bryn Mawr College, where my academic focus was on historical city development in China. During voluntary work with anti-hunger and social justice organizations in Washington, DC and Pennsylvania, I became interested in the political and social processes around food provisioning. Like many people who want to "make the world a better place," I sought to find a balance between practical service and systemic change.

The twists and turns of this exploration led me from cooking and serving meals to homeless people to international lobbying work on food and agriculture. Following a stint working in the food policy department of BEUC, the European Consumers' Organization in Brussels, I completed a master's degree in Food Policy from the City University, London. My thesis on gender issues in African urban agriculture won that year's Worshipful Company of Farmers' prize for the best thesis on farming and agriculture. Chatting with one of my teachers after the award ceremony while waiting for the rain to stop, I learned of the PUREFOOD project that funded three years of this PhD. Though I could not have imagined how my experience would unfold when I began this fellowship - through the vicissitudes of six years of academia and of life - I am glad to say that I remain interested in food. Whether I should have just gone to cooking school, only time will tell. 

Cheron Z. Constance

Wageningen School of Social Sciences (WASS)

Completed Training and Supervision Plan

Wageningen Schoo of Social Sciences

\begin{tabular}{|c|c|c|c|}
\hline Name of the learning activity & Department/Institute & Year & ECTS* \\
\hline \multicolumn{4}{|l|}{ A) Project related competences } \\
\hline PUREFOOD General Introduction course & PUREFOOD & 2011 & 1 \\
\hline Contemporary Agrifood Studies (PUREFOOD & WASS & 2011 & 6 \\
\hline \multicolumn{4}{|l|}{ Advanced Scientific Skills) } \\
\hline $\begin{array}{l}\text { Winter school and Forum on Contemporary Agri- } \\
\text { Food Issues }\end{array}$ & University of Barcelona & 2012 & 4 \\
\hline $\begin{array}{l}\text { PUREFOOD International conference } \\
\text { (organisation \& participation) }\end{array}$ & PURPLE/EC & 2014 & 1 \\
\hline \multicolumn{4}{|l|}{ B) General research related competences } \\
\hline Research Methodology & WASS/ PUREFOOD & 2011 & 1 \\
\hline Scientific Writing & Language services, WUR & 2012 & 1 \\
\hline Presentation skills & WUR Library & 2012 & 1 \\
\hline Project and Time Management & WGS/ Valley Consult & 2012 & 1 \\
\hline Introduction to Q Methodology & University of Amsterdam & 2012 & 0.5 \\
\hline $\begin{array}{l}\text { Information Literacy for PhDs ans Endnote } \\
\text { introduction }\end{array}$ & WUR Library & 2011 & 0.6 \\
\hline Writing thesis proposal & WASS & 2012 & 6 \\
\hline $\begin{array}{l}\text { 'What's in a name?: Food citizenship in food } \\
\text { projects and food co-operatives' }\end{array}$ & $\begin{array}{l}\text { Agriculture in an Urbanizing Society, } \\
\text { Wageningen and Mainstreaming } \\
\text { Co-operatives, Manchester }\end{array}$ & 2012 & 1 \\
\hline Cooperative Food Retailing & Day of Urban Agriculture, Utrecht & 2014 & 1 \\
\hline Interpretive Methods and Methodologies & WASS & 2013 & 4 \\
\hline \multicolumn{4}{|c|}{ C) Career related competences/personal development } \\
\hline Secondment & The Co-operative College & 2012 & 6 \\
\hline "Locality in meaning and practice" & $\begin{array}{l}\text { Week of lectures RSO 55806, Food } \\
\text { Sociology: Emerging theories and } \\
\text { themes }\end{array}$ & 2013 & 2.5 \\
\hline $\begin{array}{l}\text { Translating empirical findings and theory into } \\
\text { recommendations for practitioners }\end{array}$ & University of Pisa & 2012 & 1 \\
\hline $\begin{array}{l}\text { Translating empirical findings and theory into } \\
\text { policy recommendations }\end{array}$ & University of Pisa & 2012 & 1 \\
\hline Total & & & 37.6 \\
\hline
\end{tabular}

*One credit according to ECTS is on average equivalent to 28 hours of study load 



\section{FUNDING}

The research described in this thesis was financially supported from 2011-2014 by PUREFOOD (Grant Agreement Number 264719), a Marie Curie Initial Training Network funded by the European Commission's Seventh Framework PEOPLE program, and self-funded thereafter. This thesis does not reflect the opinion of the European Commission.

\section{PRINTING}

Financial support for printing this thesis came from the Department of Rural Sociology of Wageningen University \& Research and is gratefully acknowledged.

\section{PHOTOGRAPHY}

Photographs for Chapter 6, the Appendices, and the References sections taken by Saskia van Hecke. All other photographs included are by the author.

\section{DESIGN}

Thesis layout and cover design by Roderick Constance www.shadowshapes.com

Printed by Proefschriftmaken.nl

Copyright (c) 2017 Cheron Z. Constance

Contact: drczconstance@gmail.com 



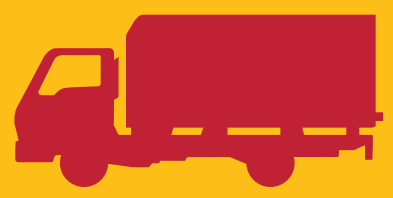

